UNIVERSIDADE DE SÃO PAULO

FACULDADE DE ECONOMIA, ADMINISTRAÇÃO E CONTABILIDADE DEPARTAMENTO DE ADMINISTRAÇÃO

PROGRAMA DE MESTRADO PROFISSIONAL EM EMPREENDEDORISMO

\title{
MARIÂNGELA PINTON
}

O Processo de Transição das Organizações para o Modelo Ágil na Gestão de Projetos de Desenvolvimento de Software 

FACULDADE DE ECONOMIA, ADMINISTRAÇÃO E CONTABILIDADE

\section{MARIÂNGELA PINTON}

O Processo de Transição das Organizações para o Modelo Ágil na Gestão de Projetos de Desenvolvimento de Software

Orientador: Prof. Dr. Alvair Silveira Torres Jr.

São Paulo 
Prof. Dr. Vahan Agopyan

Reitor da Universidade de São Paulo

Prof. Dr. Fábio Frezatti

Diretor da Faculdade de Economia, Administração e Contabilidade

Prof. Dr. Moacir de Miranda Oliveira Junior

Chefe do Departamento de Administração

Prof. Dr. Marcelo Caldeira Pedroso

Coordenador do Programa de Mestrado Profissional em Empreendedorismo 


\section{MARIÂNGELA PINTON}

\section{O Processo de Transição das Organizações para o Modelo Ágil na Gestão de Projetos de Desenvolvimento de Software}

Dissertação apresentada ao Programa de PósGraduação em Mestrado Profissional em Empreendedorismo do Departamento de Administração da Faculdade de Economia, Administração e Contabilidade da Universidade de São Paulo como requisito parcial para obtenção do título de Mestre em Ciências.

Orientador: Prof. Dr. Alvair Silveira Torres Jr.

\section{Versão Corrigida}

(versão original disponível na Biblioteca da Faculdade de Economia, Administração e Contabilidade)

\section{São Paulo}


Autorizo a reprodução e divulgação total ou parcial deste trabalho, por qualquer meio convencional ou eletrônico, para fins de estudo e pesquisa, desde que citada a fonte.

\section{Ficha Catalográfica}

Sistema de Geração de Ficha Catalográfica desenvolvido pelo Instituto de Ciências

Matemáticas e de Computação da Universidade de São Paulo

Catalogação na Publicação (CIP)

Ficha Catalográfica com dados inseridos pelo autor

Pinton, Mariangela.

O Processo de Transição das Organizações para o Modelo Ágil na Gestão de Projetos de Desenvolvimento de Software / Mariangela Pinton. São Paulo, 2020.

$210 \mathrm{p}$.

Dissertação (Mestrado) - Universidade de São Paulo, 2020.

Orientador: Alvair Silveira Torres Jr..

1. Desafios na Adoção de Modelos Ágeis. 2. Processo de Transição Ágil. 3. Frameworks de Transição Ágil. 4. Gestão de Projetos Ágeis. I. Universidade de São Paulo. Faculdade de Economia, Administração e Contabilidade. II. Título. 
FOLHA DE AVALIAÇÃO

Nome: PINTON, MARIÂNGELA

Título: O Processo de Transição das Organizações para o Modelo Ágil na Gestão de Projetos de Desenvolvimento de Software

Dissertação apresentada ao Programa de Pós-Graduação em Mestrado Profissional em Empreendedorismo do Departamento de Administração da Faculdade de Economia, Administração e Contabilidade da Universidade de São Paulo, para obtenção do título de Mestre em Ciências.

Aprovado em:

Banca Examinadora

Prof. Dr.:

Instituição:

Julgamento:

Prof. Dr.:

Instituição:

Julgamento:

Prof. Dr.:

Instituição:

Julgamento: 

Aos meus pais, que me ensinaram o verdadeiro valor da educação. 



\section{AGRADECIMENTOS}

Primeiramente, aos meus pais, Shirley e Olegário, que, como professores, me ensinaram desde criança o conceito de lifelong learning.

Às minhas irmãs, cunhados e sobrinhos, por sempre terem acreditado em mim.

Ao meu orientador, Prof. Dr. Alvair Silveira Torres Jr., por todo aprendizado durante a jornada da dissertação, fundamental para a conclusão desta pesquisa.

Aos membros da Banca de Qualificação, Prof. Dr. Marcelo Caldeira Pedroso e Prof. Dr. Antonio Geraldo da Rocha Vidal, pelas críticas e sugestões, que me ajudaram a nortear o desenvolvimento deste trabalho.

Aos demais professores do Mestrado Profissional em Empreendedorismo da Faculdade de Economia, Administração e Contabilidade da Universidade de São Paulo (FEA-USP), pela grande contribuição para o meu aprendizado. Em especial, à Prof. Dra. Jane Aparecida Marques e ao Prof. Dr. Martinho Isnard Ribeiro de Almeida, pelo apoio na definição do escopo da dissertação.

A todos os colegas da Turma 5 do Mestrado Profissional em Empreendedorismo da FEAUSP, pela inspiração e apoio durante este período. Foi um prazer fazer parte de uma turma tão especial!

A todos os entrevistados que participaram desta pesquisa, por dedicarem seu tempo e por compartilharem suas experiências profissionais. Sem vocês, este trabalho não teria sido possível.

À minha querida amiga Fernanda, por despertar em mim o interesse em cursar o Mestrado.

Ao meu namorado, Fabio, por ser sempre o meu maior fã.

Por fim, às minhas gatinhas, Amora e Ariel, por estarem sempre ao meu lado durante todos os momentos de estudo. 

"Não é o mais forte que sobrevive, nem o mais inteligente, mas o que melhor se adapta às mudanças"

(MEGGINSON, 1963, p. 4). 



\section{LISTA DE FIGURAS}

Figura 1 - Metodologia da Pesquisa ..................................................................................... 48

Figura 2 - Processo de triagem e seleção de artigos .................................................................. 51 



\section{LISTA DE QUADROS}

Quadro 1- Exemplo de Pesquisa a partir da palavra-chave "Agile Transformation Process".

Quadro 2-

Triagem dos documentos por palavras-chave

Quadro 3- Análise da coleta de dados: Transição Big Bang - Transição gradual.........................................................................................................

Quadro 4Análise da coleta de dados: Transição Big Bang - Modelo híbrido

Quadro 5 - $\quad$ Análise da coleta de dados: Preparação para a transição ágil - Motivador para a transformação

Quadro 6 - Análise da coleta de dados: Preparação para a transição ágil - Realização de assessment prévio.

Quadro 7 - Análise da coleta de dados: Preparação para a transição ágil - Aplicação de framework de transição ....

Quadro 8Análise da coleta de dados: Preparação para a transição ágil - Organização preparada

Quadro 9 - $\quad$ Análise da coleta de dados: Resultados da transição - Benefícios da transição ..

Quadro 10 - Análise da coleta de dados: Resultados da transição - Objetivos atingidos ........

Quadro 11 - Análise da coleta de dados: Resultados da transição - Realização de assessment posterior...

Quadro 12 - Análise da coleta de dados: Resultados da transição -

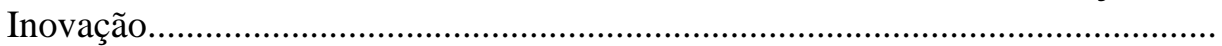

Quadro 13 - Análise da coleta de dados: Resultados da transição - Pendências da transição..

Quadro 14 - Análise da coleta de dados: Processos organizacionais

Quadro 15 - Análise da coleta de dados: Estimativas - Necessidade de estimativas..

Quadro 16 - Análise da coleta de dados: Estimativas - Conceito de MVP

Quadro 17 - Análise da coleta de dados: Estimativas - Priorização

Quadro 18 - Análise da coleta de dados: Relatórios de status.

Quadro 19- Análise da coleta de dados: Comunicação - Melhoria na comunicação.

Quadro 20 - Análise da coleta de dados: Comunicação - Visibilidade do modelo ágil

Quadro 21 -

Análise da coleta de dados: Integração com outras áreas - Implantação nas demais áreas.

Quadro 22Análise da coleta de dados: Papéis e responsabilidade - Novas responsabilidades.

Quadro 23 - Análise da coleta de dados: Papéis e responsabilidades - Perfil da equipe.............

Quadro 24 - Análise da coleta de dados: Tomada de decisão - Papel do Gerente de Projetos.

Quadro 25 - Análise da coleta de dados: Tomada de decisão - Autonomia da equipe

Quadro 26 - Análise da coleta de dados: Colaboração. 
Quadro 27 - Análise da coleta de dados: Resistência à mudança - Resistência das equipes....

Quadro 28 - Análise da coleta de dados: Resistência à mudança - Comunicação dos objetivos da transição.

Quadro 29 - Análise da coleta de dados: Resistência à mudança - Retorno ao modelo anterior.

Quadro 30 - Análise da coleta de dados: Cliente dedicado.

Quadro 31 - Análise da coleta de dados: Mudança de mindset - Cultura ágil.

Quadro 32 - Análise da coleta de dados: Mudança de mindset - Contratação de consultoria.

Quadro 33 - Análise da coleta de dados: Gestão descentralizada.

Quadro 34 - Análise da coleta de dados: Estrutura hierárquica - Redução dos níveis hierárquicos.

Quadro 35 - Análise da coleta de dados: Estrutura hierárquica - Alteração na estrutura de cargos...

Quadro 36 - Análise da coleta de dados: Estrutura hierárquica - Criação da área de Transformação Digital.

Quadro 37 - Análise da coleta de dados: Treinamento.

Quadro 38 - Análise da coleta de dados: Integração com outras áreas - Participação de Recursos Humanos

Quadro 39 - Resumo das respostas dos entrevistados - Desafios da transformação ágil ..........

Quadro 40 - Resumo das respostas dos entrevistados - Recomendações às

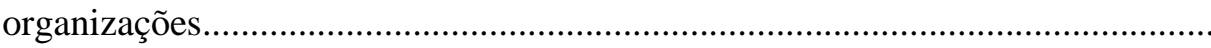

Quadro 41 - Recomendações da literatura acadêmica versus aplicabilidade pelas organizações analisadas 


\section{LISTA DE ABREVIATURAS E SIGLAS}

\begin{tabular}{ll} 
AAIM & Agile Adoption and Improvement Model \\
ACP & Agile Certified Practitioner \\
AE & Agile Expert \\
App & Application (Aplicativo) \\
ASSF & Agile Software Solution Framework \\
AST & Adaptive Structuration Theory \\
BO & Business Owner \\
BP & Business Plan (Plano de Negócios) \\
CCTA & Central Computer and Telecommunications Agency \\
CEO & Chief Executive Officer \\
DEV & Equipe de Desenvolvimento do Projeto \\
GP & Gerente de Projetos \\
IPO & Initial Public Offer \\
LACE & Lean Agile Center of Excellence \\
MP & Mariângela Pinton \\
MVP & Minimum Viable Product (Mínimo Produto Viável) \\
OKR & Objective Key Results \\
PDCA & Plan, Do, Check, Adjust (Planejar, Fazer, Verificar, Ajustar) \\
PI & Product Increment (Incremento do Produto) \\
PMG & Pequeno, Médio ou Grande \\
PMI & Project Management Institute \\
PMO & Project Management Office (Escritório de Projetos) \\
PMP & Project Management Professional \\
\hline PO & Product \\
\hline
\end{tabular}

PRINCE PRojects IN Controlled Environments

QA Quality Assurance (Equipe de Testes do Projeto)

RH Recursos Humanos

RSL Revisão Sistemática da Literatura

SAAF Strategic Agile pre-Adoption Analysis Framework

SAAP Strategic Analysis for Agile Practices 
SAFe Scaled Agile Framework

SAMI Sidky Agile Measurement Index

SLR Systematic Literature Review

SM Scrum Master

TI Tecnologia da Informação

TMO Transformation Management Office

UA Unidade de Análise

UX User Experience 


\section{RESUMO}

PINTON, Mariângela. O Processo de Transição das Organizações para o Modelo Ágil na Gestão de Projetos de Desenvolvimento de Software. 2020. 210 f. Dissertação (Mestrado Profissional em Empreendedorismo) - Faculdade de Economia, Administração e Contabilidade, Universidade de São Paulo. São Paulo, 2020.

Atualmente, em meio à Transformação Digital, a inovação é uma questão de sobrevivência para todas as organizações, mesmo para as não tecnológicas, pois devem desenvolver produtos e serviços digitais para atender às demandas deste novo mercado. Para que elas possam se manter competitivas, lançando produtos e serviços inovadores no menor time-to-market, é imprescindível que adotem modelos ágeis de gestão de projetos de desenvolvimento de software. Organizações consolidadas, que utilizam modelos de gestão de projetos tradicionais, enfrentam o grande desafio de realizar a transição para o modelo ágil, o que envolve a transformação não apenas dos seus processos, mas também da sua cultura. Nesse contexto, a presente pesquisa teve como objetivo principal elaborar um conjunto de recomendações que poderão ser adotadas pelas organizações para facilitar a transição do modelo tradicional para o ágil na gestão de projetos de desenvolvimento de software. Para tanto, foi realizada uma Pesquisa Qualitativa Exploratória utilizando-se fontes secundárias, por meio da Revisão Sistemática da Literatura (RSL), a fim de identificar os principais desafios a serem enfrentados pelas organizações, assim como as recomendações propostas. Para efeito de análise, os desafios e recomendações foram categorizados em: Processos, Pessoas, Gestão e Organização. Posteriormente, para a coleta de dados, foram utilizadas fontes primárias, por meio de entrevistas semiestruturadas realizadas com dez funcionários de oito organizações nacionais e multinacionais de diversos segmentos, como Tecnologia da Informação, Financeiro e outros, que já tivessem participado do processo de transição para o modelo ágil. Tais dados foram então compilados, para que se pudesse identificar, dentre as práticas recomendadas pela literatura, quais delas estavam sendo aplicadas pelas organizações em questão e quais delas facilitam o processo de transição. A análise comparativa permitiu concluir que a transição para o modelo ágil causa grande impacto nas pessoas e, por esta razão, as principais práticas a serem adotadas estão relacionadas à necessidade de reduzir a resistência das equipes, tanto no nível operacional quanto no executivo, devido às mudanças de papéis e de responsabilidades; aos novos valores ágeis de colaboração; e à tomada de decisão descentralizada. Constatou-se também que, antes de iniciar a transição, é importante que a organização tenha claramente definido qual o nível de maturidade ágil que almeja, adaptado ao seu contexto e à sua cultura, e que obtenha o apoio dos seus executivos. É necessário, inclusive, que a transição seja uma iniciativa da organização como um todo e não apenas de algumas de suas áreas.

Palavras-chave: Desafios na Adoção de Modelos Ágeis. Processo de Transição Ágil. Frameworks de Transição Ágil. Gestão de Projetos Ágeis. 



\begin{abstract}
PINTON, Mariângela. The transition process of organizations to the Agile Model in software development project management. 2020. 210 p. Dissertation (Professional Master in Entrepreneurship) - Faculdade de Economia, Administração e Contabilidade, Universidade de São Paulo. São Paulo, 2020.

Currently, in the midst of Digital Transformation, innovation is a survival issue for all organizations, even for the non-technological ones, as they must develop digital products and services to meet the demands of this new market. In order to remain competitive, launching innovative products and services in the shortest time-to-market, it is essential that they adopt agile project management models for software development. Consolidated organizations, which use traditional project management models, face the great challenge of transitioning to the agile model, which necessarily involves transforming not only their processes, but also their culture. In this context, the main objective of this research was to develop a set of practical recommendations to be adopted by the organizations to facilitate this transition from the traditional to the agile model in software development project management. For that, an Exploratory Qualitative Research was carried out, using secondary sources, by means of a Systematic Literature Review (SLR), seeking to identify the main challenges to be faced by the organizations, as well as the proposed recommendations. For analysis purposes, these challenges and recommendations were categorized as: Process, People, Management and Organization. Subsequently, primary sources were used for data collection, by means of semistructured interviews with ten employees from eight national and multinational organizations of different segments, such as IT, Financial sector and others, which had already participated in the transition process to the agile model. These data were then compiled, so that it was possible to identify, among the practices recommended by the literature in question, which of them were being applied by these organizations and which of them facilitated the transition process. The comparative analysis allowed us to conclude that the transition to the agile model causes great impact on people and, for this reason, the main practices to be adopted are related to the need to reduce the resistance of the teams, both at the operational and executive levels, due to changes in roles and responsibilities; in the new agile values of collaboration; and in the decentralized decision-making process. In addition, it was also found that, before starting the transition, it is important that the organization clearly defines which level of agile maturity it wants to achieve, adapted to its context and to its culture, and that it obtains the support of executives. It is also necessary that the transition be an initiative of the organization as a whole and not just of some of its areas.
\end{abstract}

Keywords: Agile Adoption Challenges. Agile Transition Process. Agile Transition Framework. Agile Project Management. 



\section{SUMÁRIO}

1. INTRODUÇÃ

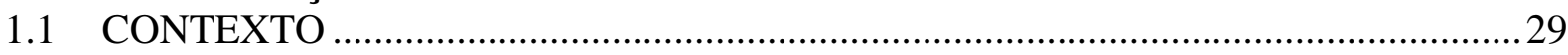

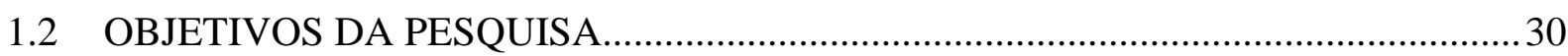

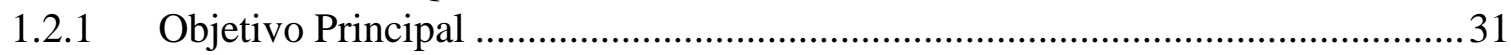

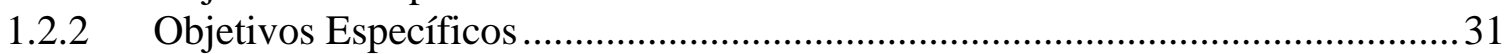

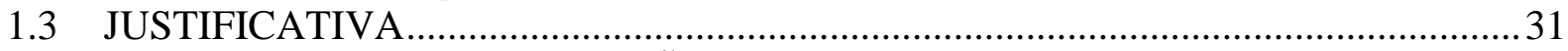

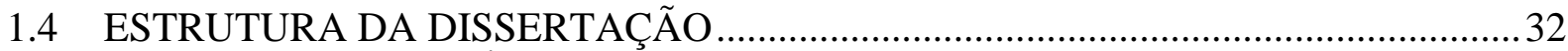

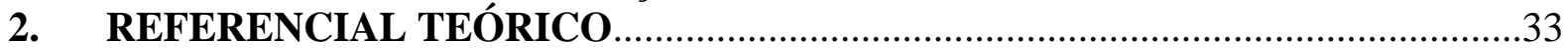

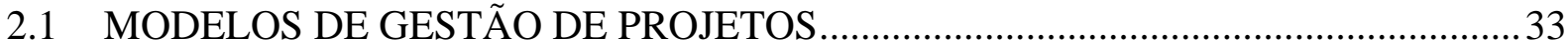

2.1.1 Modelos de Gestão de Projetos Tradicionais ....................................................... 34

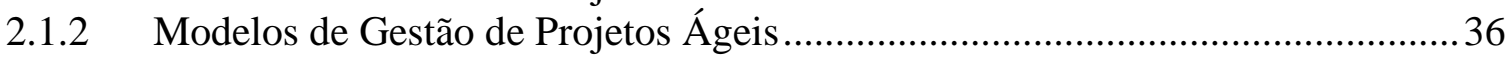

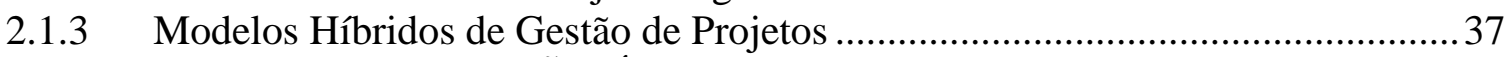

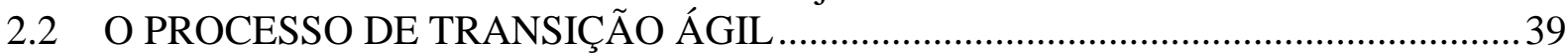

2.3 FRAMEWORKS PARA A TRANSIÇÃO PARA O MODELO ÁGIL ...........................42

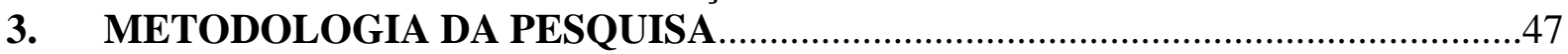

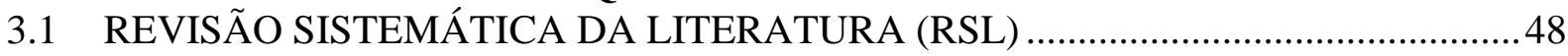

3.1.1 Definição dos Objetivos da Pesquisa .............................................................. 48

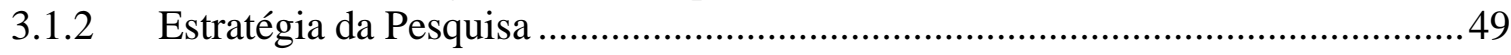

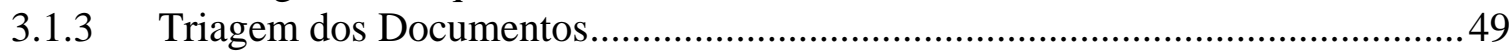

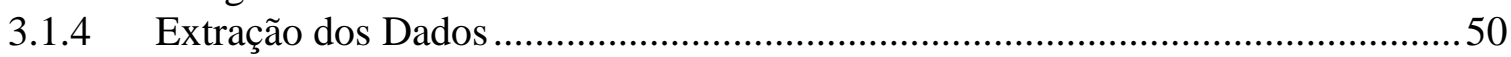

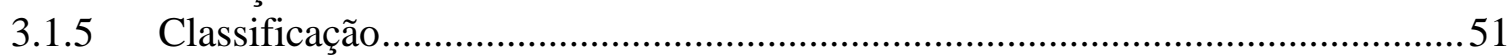

3.2 PROCEDIMENTOS PARA A COLETA DE DADOS PRIMÁRIOS ...........................52

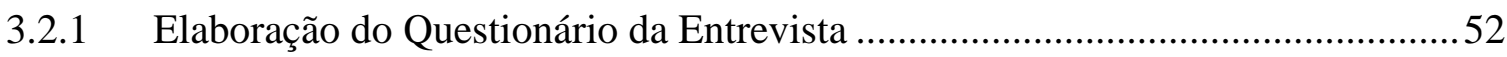

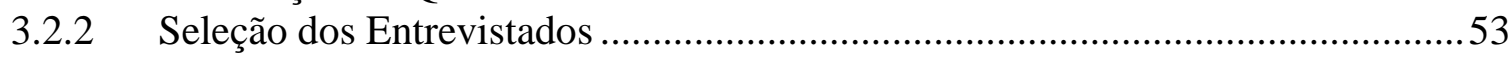

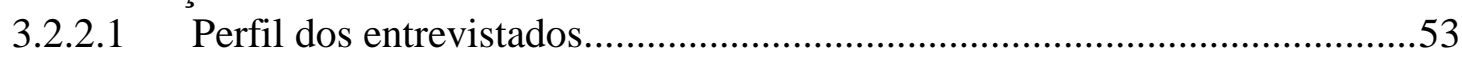

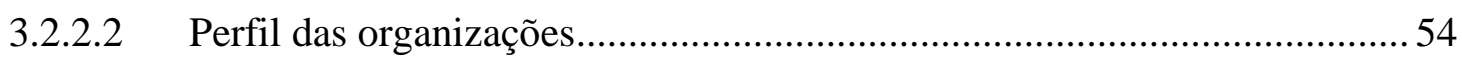

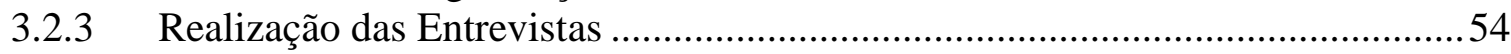

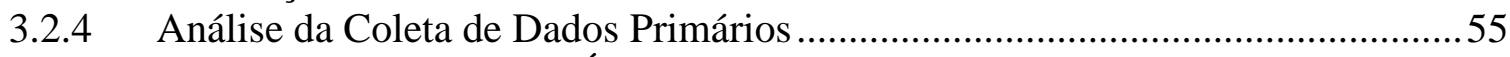

3.3 PROCEDIMENTOS PARA ANÁLISE DOS RESULTADOS ...................................56

3.3.1 Mapeamento dos Desafios e Recomendações.......................................................56

3.3.2 Análise da Aplicabilidade das Práticas Recomendadas pela Literatura Acadêmica ................................................................................................ 57

3.3.3 Análise da Aplicabilidade das Práticas Recomendadas .......................................57

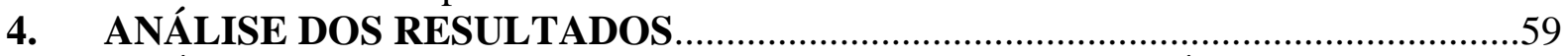

4.1 ANÁLISE DOS RESULTADOS DA REVISÃO SISTEMÁTICA DA

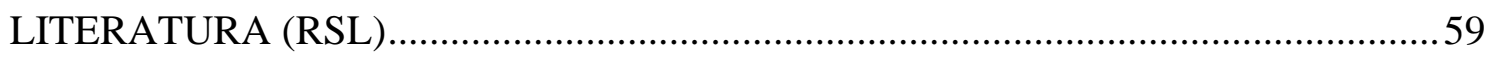

4.1.1 Desafios de Processos na Análise da RSL ..........................................................59

4.1.1.1 Transição Big Bang - RSL (UA 1) ............................................................59

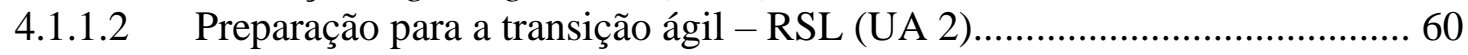

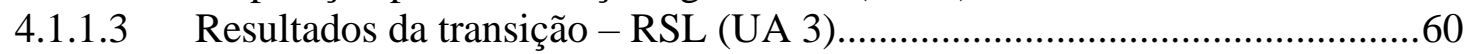

4.1.1.4 Processos organizacionais - RSL (UA 4) .................................................6

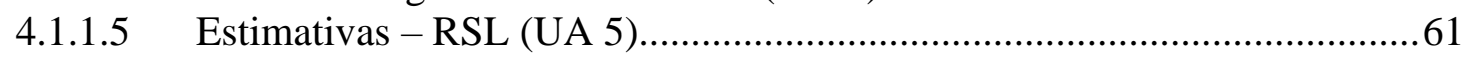

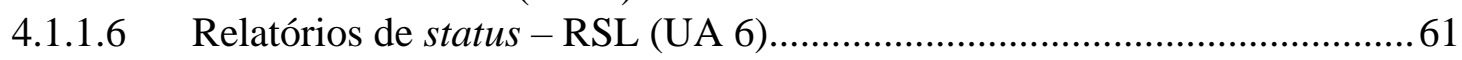

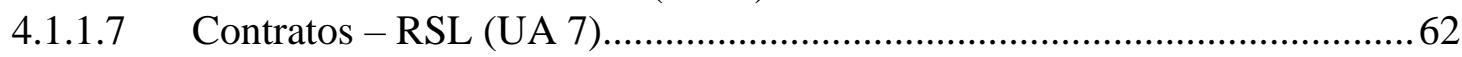

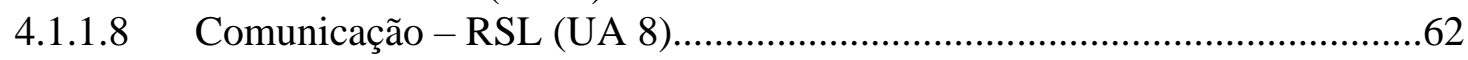

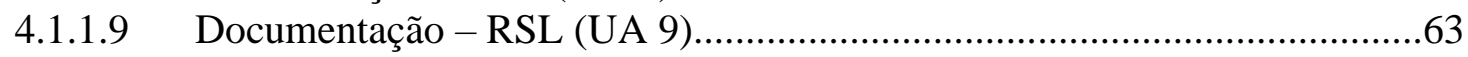

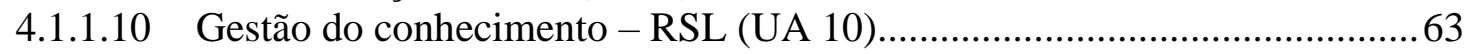

4.1.1.11 Integração com outras áreas - RSL (UA 11) ..............................................63 


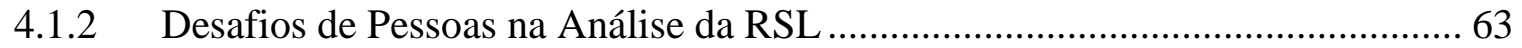

4.1.2.1 Estruturação da equipe - RSL (UA 12) ................................................64

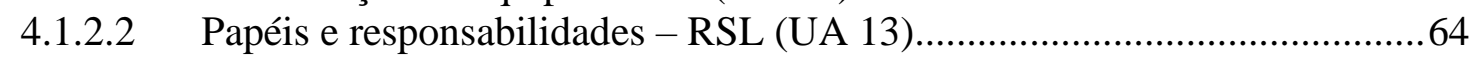

4.1.2.3 Tomada de decisão - RSL (UA 14) ......................................................65

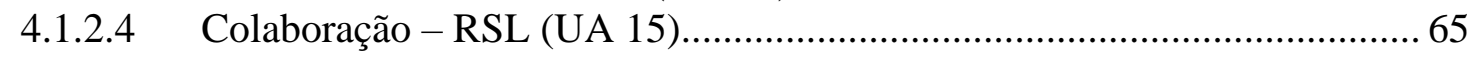

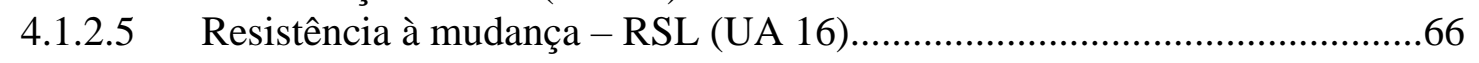

4.1.2.6 Cliente dedicado - RSL (UA 17) ..........................................................66

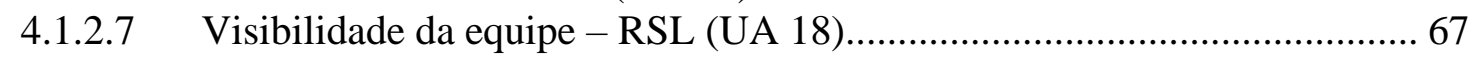

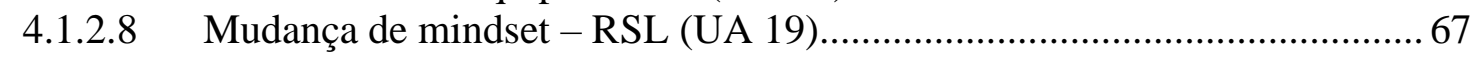

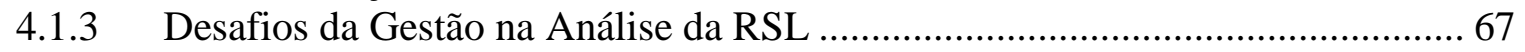

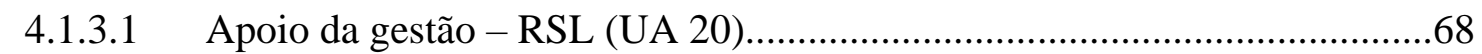

4.1.3.2 Gestão descentralizada - RSL (UA 21) ...................................................68

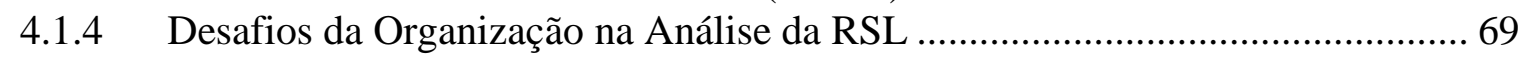

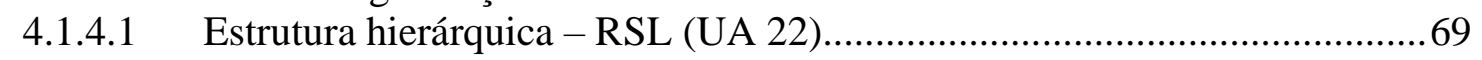

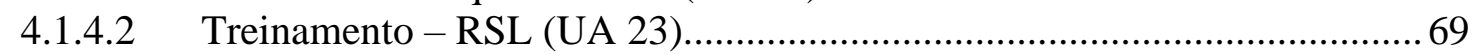

4.1.4.3 Contratação de profissionais - RSL (UA 24)........................................... 70

4.1.4.4 Avaliação de performance - RSL (UA 25) ............................................. 70

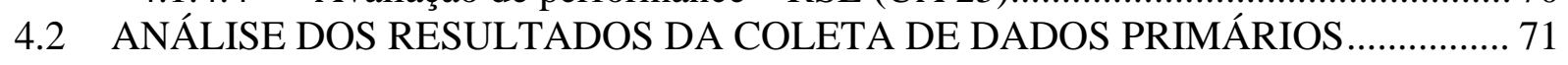

4.2.1 Desafios de Processos na Análise da Coleta de Dados Primários ...................... 71

4.2.1.1 Transição Big Bang - coleta de dados primários (UA 1)............................71

4.2.1.2 Preparação para a transição ágil - coleta de dados primários (UA 2)..........77

4.2.1.3 Resultados da transição - coleta de dados primários (UA 3)....................... 87

4.2.1.4 Processos organizacionais - coleta de dados primários (UA 4).................98

4.2.1.5 Estimativas - coleta de dados primários (UA 5)....................................... 99

4.2.1.6 Relatórios de status - coleta de dados primários (UA 6)..........................106

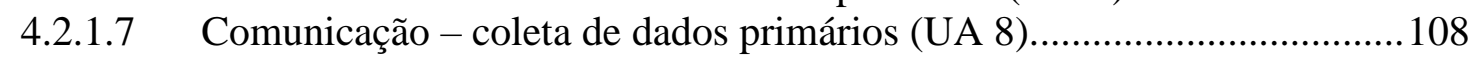

4.2.1.8 Integração com outras áreas - coleta de dados primários (UA 11)........... 112

4.2.2 Desafios de Pessoas na Análise da Coleta de Dados Primários ........................ 114

4.2.2.1 Papéis e responsabilidades - coleta de dados primários (UA 13)............ 114

4.2.2.2 Tomada de decisão - coleta de dados primários (UA 14) ............................ 118

4.2.2.3 Colaboração - coleta de dados primários (UA 15).........................................123

4.2.2.4 Resistência à Mudança - coleta de dados primários (UA 16).................... 125

4.2.2.5 Cliente dedicado - coleta de dados primários (UA 17)..............................131

4.2.2.6 Mudança de mindset - coleta de dados primários (UA 19)...................... 133

4.2.3 Desafios da Gestão na Análise da Coleta de Dados Primários............................. 138

4.2.3.1 Gestão descentralizada - coleta de dados primários (UA 21).................... 138

4.2.4 Desafios da Organização na Análise da Coleta de Dados Primários.................. 141

4.2.4.1 Estrutura hierárquica - coleta de dados primários (UA 22)...................... 141

4.2.4.2 Treinamento - coleta de dados primários (UA 23)................................... 146

4.3 MAPEAMENTO DOS DESAFIOS E RECOMENDAÇÕES COM BASE NA

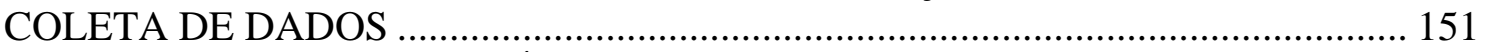

4.4 APLICABILIDADE DAS PRÁTICAS RECOMENDADAS PELA

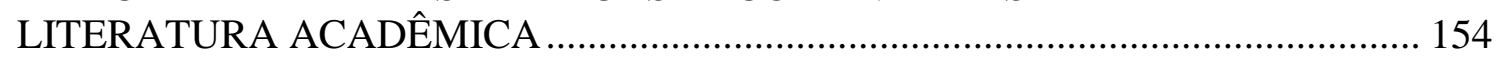

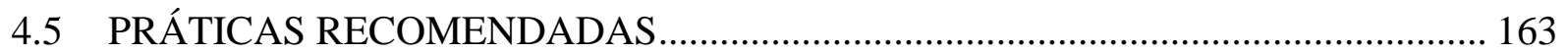

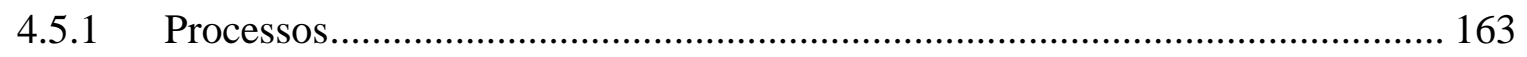

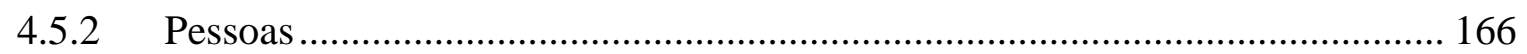

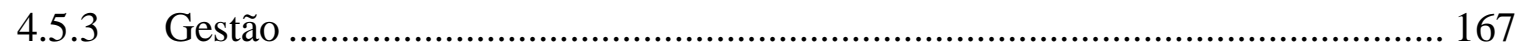

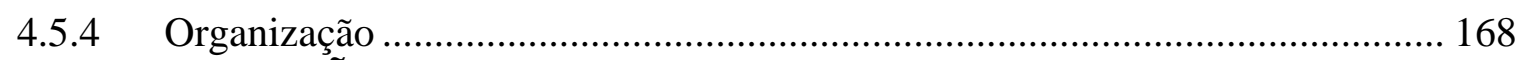

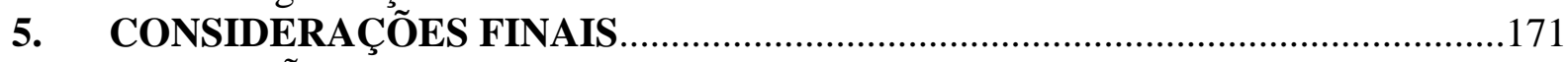

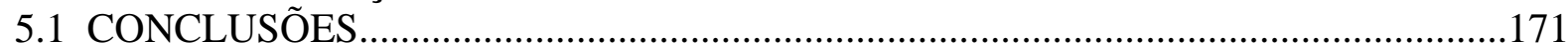




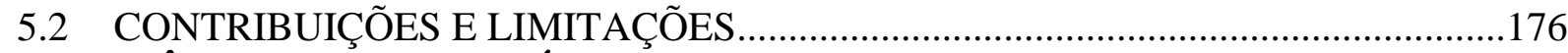

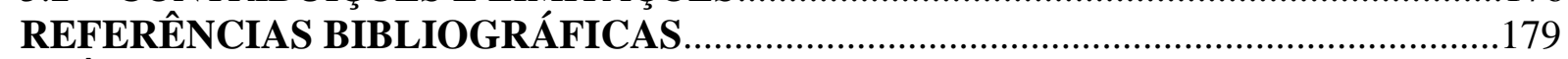

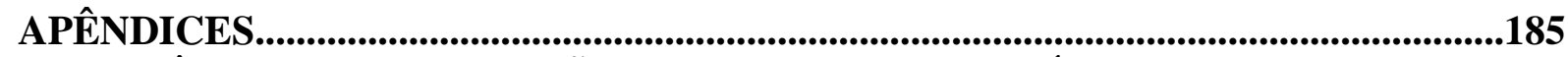

APÊNDICE A - EXTRAÇÃO DOS DADOS SECUNDÁRIOS..............................185

APÊNDICE B - DESAFIOS DE PROCESSOS ...................................................189

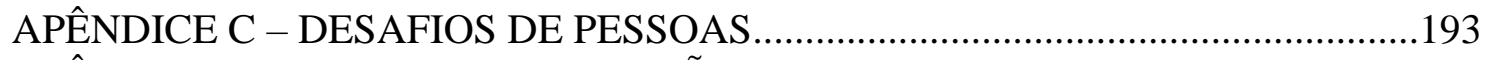

APÊNDICE D - DESAFIOS DE GESTÃO_........................................................ 197

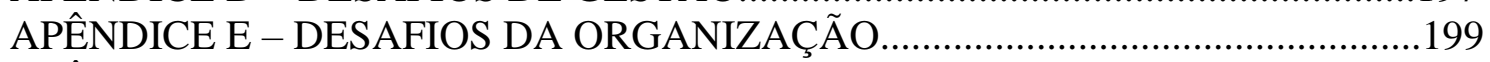

APÊNDICE F - PERFIL DOS ENTREVISTADOS E DAS RESPECTIVAS

ORGANIZAÇÕES..........................................................................201

APÊNDICE G - COLETA DE DADOS PRIMÁRIOS - FORMULÁRIO INICIAL..203

APÊNDICE H - QUESTIONÁRIO DA ENTREVISTA............................................205

APÊNDICE I - CARTA DE APRESENTAÇÃO PARA REALIZAÇÃO DA

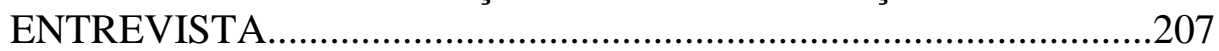

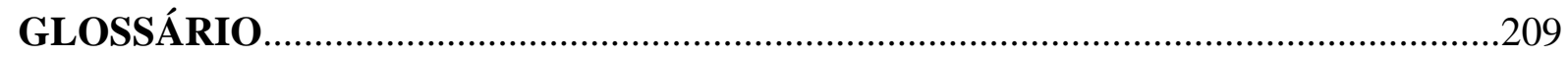





\section{INTRODUÇÃO}

\subsection{CONTEXTO}

Atualmente, a inovação é um fator decisivo para a sobrevivência das organizações, tanto para as já consolidadas quanto para as startups. A Transformação Digital demanda que, mesmo organizações não tecnológicas, que possuam seu negócio tradicional em outros segmentos, mas que utilizem a tecnologia como meio para a geração de valor, estejam aptas a inovar. Para lançar seus produtos e serviços de tecnologia de forma eficiente, com o menor time-to-market, e atendendo à nova demanda dos consumidores, é imprescindível que as organizações adotem modelos adequados de gestão de projetos de desenvolvimento de software.

Este cenário, caracterizado por profundas transformações na área de tecnologia, e pela conexão do mundo físico com o virtual por meio da digitalização dos serviços, apresenta crescimento exponencial e elevado grau de incertezas (MEANS; SCHWAB, 2015). Por este motivo, requer-se um dinamismo muito maior do que há algumas décadas, quando foram criados os principais modelos tradicionais de gestão de projetos. Tais modelos, baseados em planejamento de projeto e na definição do escopo fixo, vêm recebendo muitas críticas em relação aos processos burocráticos que propõem (BOEHM, 2002; LINDVAL et al., 2004), representando, então, um fator limitante para a inovação, devido ao impacto direto no prazo de desenvolvimento dos projetos e, consequentemente, no lançamento dos produtos e serviços no mercado.

Neste contexto, a partir de 2001, vêm surgindo modelos ágeis de gestão de projetos, visando à maior simplicidade e flexibilidade nos processos, de modo a atender às demandas dos clientes em meio a um mercado digital acelerado e incerto. Estes modelos estão mais adaptados ao cenário atual de inovação tecnológica, pois se baseiam na priorização de funcionalidades de acordo com o seu valor para o negócio (SCHWABER; SUTHERLAND, 2017; LEE et al., 2018).

Diversas startups, criadas após tal data, já nasceram utilizando modelos ágeis na gestão de seus projetos de desenvolvimento de software, enquanto organizações já consolidadas, que utilizavam modelos de gestão de projetos tradicionais, têm a necessidade de transformar seus processos internos e sua cultura para poderem migrar para os modelos ágeis. Esta transição, com a finalidade de inserir uma abordagem ágil em um ambiente tradicional e 
hierárquico, representa um grande desafio para as organizações, pois envolve inevitavelmente uma mudança de mindset.

Apesar dos evidentes benefícios proporcionados pelo modelo ágil, como o foco no cliente e o menor time-to-market no lançamento de produtos e serviços, a transição para o modelo ágil e sua efetiva implantação apresentam diversos desafios intrínsecos, o que inclui, inclusive, a necessidade de disponibilização de tempo e de esforços (GANDOMANI; ZULZALIL;GHANI; SULTAN; NAFCHI， 2013; GANDOMANI; NAFCHI， 2015; GANDOMANI; ZULZALIL; GHANI; SULTAN; SHARIF, 2014). Mesmo assim, a transição ágil é considerada um passo importante da Transformação Digital e é de extrema importância para que as organizações já consolidadas possam evoluir nos processos internos e se manter competitivas no mercado por meio da inovação.

Esta dualidade entre os desafios e os benefícios da implantação do modelo ágil resultou em diversas pesquisas recentes na literatura acadêmica, com o objetivo de encontrar a melhor forma de potencializá-los, mas considerando-se as particularidades de cada negócio ou organização. A utilização de modelos ágeis por si só não fará com que a organização se torne mais eficiente e inovadora, como afirmam diversos autores analisados. Além disso, não há um modelo único, padrão, adequado a todos os tipos de projetos ou organizações (one size does not fit all) (LINDVALL et al., 2004; CONBOY; FITZGERALD, 2010). Por isso, os modelos de gestão de projetos devem ser aplicados de acordo com o contexto específico de cada organização, utilizando-se para tanto apenas as práticas ágeis que façam sentido para a mesma (BOEHM, 2002; BOEHM; TURNER, 2003).

\subsection{OBJETIVOS DA PESQUISA}

Diante deste cenário de Transformação Digital e da necessidade de inovação tecnológica pelas organizações, definiu-se o seguinte problema de pesquisa: A transição do modelo tradicional para o modelo ágil, na gestão de projetos de desenvolvimento de software, é uma necessidade para as organizações, mas também um desafio.

A partir deste problema pré-concebido, formulou-se a seguinte pergunta de pesquisa: Quais são as principais práticas que facilitam a transição do modelo tradicional para o ágil na gestão de projetos de desenvolvimento de software?

Visando a responder a esta pergunta, foram definidos o objetivo principal e os específicos, apresentados a seguir. 


\subsubsection{Objetivo Principal}

O objetivo principal da presente dissertação foi "Elaborar um conjunto de práticas recomendadas, a serem adotadas pelas organizações, para facilitar o processo de transição do modelo tradicional para o ágil na gestão de projetos de desenvolvimento de software”.

\subsubsection{Objetivos Específicos}

Os objetivos específicos da presente dissertação foram:

a) Identificar os desafios encontrados pelas organizações na transição do modelo tradicional para o ágil;

b) Identificar as recomendações propostas pelas organizações para superar os desafios da transição;

c) Verificar se as organizações analisadas estão aplicando as práticas de transição ágil recomendadas pela literatura acadêmica.

\section{$1.3 \quad$ JUSTIFICATIVA}

A presente dissertação estabelece um diálogo entre a literatura acadêmica e a análise empírica no que tange à gestão de projetos de desenvolvimento de software, consolidando as melhores práticas de adoção do modelo ágil por organizações tradicionais. Espera-se que tal estudo contribua para as organizações que tenham intenção de se transformar do modelo tradicional para o ágil, por meio do conhecimento dos desafios enfrentados por aquelas que já realizaram tal processo, visando a minimizar os riscos desta transição. As recomendações propostas poderão, eventualmente, ser usadas para fins de planejamento e de acompanhamento do processo de transição pelas organizações que estejam em processo de transição.

Partindo-se do pressuposto que a transição ágil é um processo sociotécnico, ou seja, envolve tanto transformações nos processos quanto nas pessoas (GANDOMANI; NAFCHI, 2015), os critérios culturais das organizações devem considerados. Este conhecimento é extremamente relevante para as organizações, uma vez que, em função do cenário competitivo atual, devem ser adotados modelos cada vez mais eficientes no desenvolvimento de produtos e de serviços inovadores e, simultaneamente, também devem ser consideradas as necessidades dos clientes e a estratégia corporativa. Apesar de a implantação do modelo ágil 
levar ao enfrentamento de inúmeros desafios, sua adoção é imprescindível para que as organizações possam realizar sua Transformação Digital.

\subsection{ESTRUTURA DA DISSERTAÇÃO}

Para atingir os objetivos propostos, a presente dissertação foi estruturada em cinco Capítulos, a saber: no Capítulo 1 - Introdução, são apresentados o contexto e os objetivos da pesquisa. No Capítulo 2 - Referencial Teórico, são apresentados os conceitos estabelecidos por diversos autores referentes aos Modelos de Gestão de Projetos Tradicionais, aos Modelos de Gestão de Projetos Ágeis e aos Modelos Híbridos, assim como o Processo de Transição Ágil e os Frameworks para a transição para o Modelo Ágil. No Capítulo 3 - Metodologia de Pesquisa, são apresentados os procedimentos adotados para a coleta de dados, tanto em relação à definição do campo de busca em fontes secundárias, para realização da Revisão Sistemática da Literatura (RSL), quanto em relação às fontes primárias, definindo-se critérios para escolha dos entrevistados e organizações, assim como a metodologia de realização das entrevistas. Também estão detalhados os procedimentos utilizados para a Análise de Resultados. No Capítulo 4 - Análise dos Resultados, são apresentados detalhadamente os resultados obtidos pela análise da RSL e pelas entrevistas e as conclusões obtidas. No Capítulo 5 - Considerações Finais, é apresentada a conclusão da presente dissertação, suas limitações e contribuições. Constam também as Referências Bibliografias utilizadas e nove Apêndices com dados complementares à argumentação da presente pesquisa. 


\section{REFERENCIAL TEÓRICO}

O referencial teórico que dá suporte ao objeto da presente pesquisa e às linhas teóricas que sustentam o tema foi agrupado em 3 grandes questões: Modelos de Gestão de Projetos (que envolve os Modelos de Gestão de Projetos Tradicionais, os Modelos de Gestão de Projetos Ágeis e os Modelos de Gestão Híbridos), Processos de Transição Ágil e Frameworks para a Transição para o Modelo Ágil.

Cabe esclarecer, primeiramente, que projetos podem ser definidos como processos únicos, com início, meio e fim, tendo um objetivo principal, por exemplo, a criação de um produto ou serviço digital. Para atingir tais objetivos, surgiram os modelos de gestão de projetos, que envolvem uma sequência de atividades a serem realizadas durante sua execução, buscando aumentar as chances de sucesso.

\subsection{MODELOS DE GESTÃO DE PROJETOS}

Os Modelos de Gestão de Projetos Tradicionais foram formalizados a partir da década de 1960, com a criação do Project Management Institute (PMI), nos Estados Unidos, que definiu um processo sequencial de práticas de gestão de projetos denominado Project Management Professional (PMP). O principal objetivo do PMI é compartilhar os conhecimentos entre seus participantes e padronizar a gestão de projetos de acordo com as melhores práticas identificadas (PROJECT MANAGEMENT INSTITUTE - PMI, n.d.).

Duas décadas depois, o Reino Unido também formalizou o PRojects IN Controlled Environments (PRINCE2), como um modelo de gestão de projetos baseado em fases gerenciáveis, com foco no produto e na justificativa do negócio (CENTRAL COMPUTER AND TELECOMMUNICATIONS AGENCY - CCTA, n.d.).

Ambos os modelos foram difundidos mundialmente e deram origem a diversos outros processos que auxiliam na gestão de projetos de indústrias de diversas áreas, tais como as de tecnologia, as de manufatura e as de construção civil. Suas principais características são a elaboração do planejamento detalhado do projeto e a realização das atividades de forma sequencial.

Neste contexto, surgem os Modelos de Gestão de Projetos Ágeis, que se propõem a simplificar os processos burocráticos propostos pelos modelos tradicionais, focando em novos valores, até então não enfatizados (BOEHM, 2002). Estes modelos adaptam-se melhor ao 
mercado dinâmico atual, pois são mais tolerantes a mudanças, focam na entrega de produtos que atendem às necessidades do cliente e possuem menor time-to-market no seu lançamento (CHEN; RAVICHANDAR; PROCTOR, 2016).

Nos últimos anos, os Modelos de Gestão de Projetos Ágeis vêm ganhando popularidade (NERUR; MAHAPATRA; MANGALARAJ, 2005), pois cada vez mais as organizações estão em busca de agilidade na execução de seus projetos (CAO; XU; RAMESH, 2009). Mesmo instituições tradicionais, como o PMI e o PRINCE2, reconhecem esta necessidade e adaptam seus processos para atenderem a este novo mercado, resultando em modelos com conceitos mais flexíveis, tais como o PMI-Agile Certified Practitioner (PROJECT MANAGEMENT INSTITUTE - PMI, n.d.) e o PRINCE2 Agile Foundation \& Practicioner (CENTRAL COMPUTER AND TELECOMMUNICATIONS AGENCY CCTA, n.d.).

O conceito de agilidade foi consolidado no desenvolvimento de software apenas em 2001, com o Manifesto Ágil (BECK et al., 2001), tendo sido adaptado da filosofia lean, criada na década de 1950, na indústria automotiva japonesa, com o lean production, e aplicada nas demais indústrias na década de 1990, por meio do lean thinking (POTH; SASABE; MAS; MESQUIDA, 2018). O Manifesto Ágil trouxe os conceitos lean para a indústria de desenvolvimento de software, tais como ciclos curtos de desenvolvimento, resposta rápida a mudanças e eliminação de desperdícios, priorizando o desenvolvimento de funcionalidades que geram maior valor para o cliente e maior colaboração entre os membros da equipe (DINGSØYR; NERUR; BALIJEPALLY; MOE, 2012; POTH et al., 2018). O Manifesto Ágil está baseado em quatro valores principais: valorização das pessoas sobre os processos; do funcionamento do software sobre a documentação; da colaboração em equipe sobre o contrato com o cliente; e da resposta rápida sobre o cumprimento do plano (BECK et al., 2001).

\subsubsection{Modelos de Gestão de Projetos Tradicionais}

Os modelos de gestão de projetos tradicionais são baseados no planejamento e possuem fases bem definidas. No PMP, por exemplo, as fases de iniciação, planejamento, execução, monitoramento e controle, e encerramento são executadas sequencialmente, ou em cascata.

Durante a fase de planejamento, devem ser estabelecidas e mapeadas as definições do projeto, como: escopo, custo e prazo de entrega (PROJECT MANAGEMENT INSTITUTE - 
PMI, n.d.). Ainda durante esta fase, também deve ser detalhada a documentação formal do projeto, incluindo: o mapeamento de todos os requerimentos e os cenários de testes; a definição do plano de comunicação e os indicadores do projeto; a alocação de equipes e a aquisição de fornecedores (caso necessário). Somente depois de concluída esta fase, é então iniciada sua execução (PROJECT MANAGEMENT INSTITUTE - PMI, n.d.).

Os artefatos, construídos durante a fase de planejamento, devem ser acompanhados na fase de monitoramento e controle, por meio de medição dos indicadores de desempenho, identificação de variações da execução em relação ao planejamento e gerenciamento de riscos e issues. Nesta fase, também é realizada a gestão de mudanças, acarretando alterações no escopo, no prazo e nos custos, no replanejamento do projeto e na aceitação dos impactos pelo cliente, caso necessário.

Devido às características supramencionadas, os modelos tradicionais são mais adaptáveis a ambientes estáveis e a projetos que necessitem de planejamento antecipado, com um escopo bem definido desde o seu início como, por exemplo, contratos com escopo fixo. Tais modelos também podem ser recomendados para projetos grandes e complexos ou que possuam equipes distribuídas, a fim de que a documentação possa ser compartilhada entre as equipes e o conhecimento não seja perdido ao longo do tempo (MAHANTI, 2006).

Por outro lado, em ambientes de maior volatilidade, as especificações iniciais podem se tornar obsoletas no momento da entrega do projeto (LINDVAL et al., 2004). Além disso, as frequentes alterações realizadas podem resultar na entrega tardia do produto final, oferecendo um risco maior de a organização investir em funcionalidades que não gerem valor para o cliente. Devido a esta lenta resposta às mudanças de requerimentos em meio a um cenário acelerado e também à maior pressão para a redução de custos nos projetos de desenvolvimento de software observada nas últimas duas décadas, os modelos tradicionais passaram a ser considerados burocráticos e ineficientes (LINDVAL et al., 2004).

O processo sequencial dos modelos tradicionais começou a receber profundas críticas nos últimos anos, devido à necessidade de adaptação ao novo mercado competitivo, que demanda a implementação de projetos no menor tempo possível. Além disso, por se tratar de um ambiente de incertezas, há grande dificuldade em definir todos os requerimentos na fase de planejamento do projeto, acarretando diversas alterações durante sua execução, na medida em que forem sendo identificadas novas necessidades (LINDVAL et al., 2004). Estas alterações ocasionam o frequente replanejamento do projeto e, consequentemente, a insatisfação do cliente, que receberá o produto final com prazos e custos adicionais. Por estes motivos, os índices de insucesso dos projetos se tornaram elevados (MAHANTI, 2006) e as 
organizações passaram a buscar novos processos para gerenciar os projetos de forma mais flexível e mais adaptados ao mercado atual, focado no cliente final. Como reação a esta necessidade, foram criados modelos mais simples e flexíveis, adaptados às frequentes mudanças de escopo e à velocidade do mercado atual.

\subsubsection{Modelos de Gestão de Projetos Ágeis}

Dentre os diversos modelos ágeis atuais, o Scrum (SCHWABER; SUTHERLAND, 2017) e o XP - Extreme Programming (FITZGERALD; HARTNETT; CONBOY, 2017) destacam-se como os mais utilizados na indústria de software mundial. Enquanto o XP é um modelo focado nos aspectos técnicos do desenvolvimento de software, utilizando conceitos de programação em pares e padrões de desenvolvimento; o Scrum, por sua vez, descreve o processo de planejamento e de monitoramento do projeto. Assim, tais modelos podem ser considerados complementares (FITZGERALD et al., 2017). Apesar de cada um dos modelos propor práticas diferentes, ambos se baseiam nos valores propostos pelo Manifesto Ágil (GANDOMANI; ZULZALIL; GHANI;SULTAN, 2013).

Os principais benefícios dos modelos ágeis são: a redução de custo; a redução de timeto-market; a melhoria da qualidade do produto entregue; e a maior flexibilidade para incluir mudanças (MAHANTI, 2006). Estes benefícios baseiam-se na abordagem iterativa e incremental do projeto, priorizando tanto a entrega de funcionalidades que trazem maior valor para o negócio quanto a geração de entregáveis em ciclos curtos de desenvolvimento. Estes entregáveis podem ser testados pelo cliente em um curto espaço de tempo, resultando na rápida detecção de problemas e representando uma eficiente medida de progresso do projeto. Em relação às pessoas, o modelo ágil prevê uma maior comunicação e colaboração entre as equipes, suportando os conceitos de equipes auto-organizáveis e permitindo maior autonomia para a tomada de decisões, o que impacta positivamente a produtividade do projeto (BOEHM; TURNER, 2005).

Na última década, com a evolução da mobilidade e a necessidade de desenvolvimento de aplicativos para esta nova indústria, surgiu também o conceito lean startup (RIES, 2011). Este conceito mantém as mesmas características ágeis de ciclos curtos de desenvolvimento, redução do desperdício e rápida adaptação à mudança, porém, com maior foco no cliente final, com o objetivo de lançar produtos e serviços desejáveis para o cliente. Através do conceito Mininum Viable Product (MVP), os produtos são lançados no mercado o mais cedo possível, antes mesmo do desenvolvimento de todas as suas funcionalidades. O feedback do 
cliente é utilizado como critério de aceitação e de priorização das novas funcionalidades a serem desenvolvidas.

Comparando-se os modelos tradicionais com os ágeis, pode-se constatar uma ruptura do conceito, principalmente em relação ao planejamento, à definição de escopo e à gestão de mudanças. Enquanto nos modelos tradicionais o escopo é detalhado no início do projeto, e a partir dele são definidos o custo e o prazo de entrega; nos modelos ágeis o escopo é variável, priorizado a partir das necessidades que trazem maior retorno para o cliente naquele momento. Depois da entrega de cada versão do software, serão detalhadas as próximas funcionalidades a serem desenvolvidas, incrementando, então, o produto já entregue. Neste caso, o intervalo de tempo é fixo. A partir dele, são definidas quais funcionalidades podem ser entregues naquele período, de acordo com o valor que podem gerar para o negócio.

Estas entregas frequentes de partes do produto permitem o rápido feedback do cliente e a introdução do produto no mercado em um curto intervalo de tempo, além de reduzirem o desperdício, entregando funcionalidades utilizadas pelos usuários e possibilitando a detecção e a correção de problemas antecipadamente. Como consequência, as mudanças de escopo são tratadas de forma mais natural, sempre atendendo às necessidades dos clientes. Sendo assim, pode-se afirmar que os modelos ágeis trouxeram novos valores de foco no cliente e na equipe do projeto, não enfatizados nos modelos tradicionais, proporcionando uma profunda transformação na gestão e na execução de projetos (DINGSØYR et al., 2012; NERUR; MAHAPATRA; MANGALARAJ, 2005).

\subsubsection{Modelos Híbridos de Gestão de Projetos}

Enquanto os modelos de projetos tradicionais são baseados no planejamento, os modelos ágeis são baseados nas pessoas; os modelos tradicionais são mais recomendados para projetos grandes, distribuídos e complexos, enquanto os modelos ágeis adaptam-se melhor a projetos menores e com equipe local; e os tradicionais são adequados para ambientes que requerem previsibilidade e para projetos com requerimentos bem definidos, enquanto os ágeis, para ambientes de rápida mudança e para projetos com requerimentos incertos.

Estas diferenças fazem com que cada modelo possua características que performam melhor em ambientes específicos, não havendo um modelo único, adaptável a todo tipo de organização ou de projeto (one size does not fit all) (LINDVALL et al., 2004; CONBOY; FITZGERALD, 2010). Este fato faz com que as empresas customizem seus modelos, combinando práticas dos modelos tradicionais com as dos modelos ágeis, resultando, então, 
na criação de modelos híbridos (KALUS; KUHRMANN, 2013; MAHANTI, 2006; LINDVAL et al., 2004).

A customização de modelos de gestão de projetos, ou tailoring, apesar de ser um tema bem aceito no mercado, é bastante novo, tendo surgido somente depois da identificação dos desafios na adoção de modelos ágeis e da criação de modelos híbridos pelas organizações (CAMPANELLI; PARREIRAS, 2015; FITZGERALD et al., 2017).

Os modelos híbridos trazem benefícios adicionais, quando comparados com a adoção de apenas um dos modelos, e se adaptam à realidade das organizações (BOEHM, 2002). Há muitas vantagens na combinação das práticas tradicionais com as ágeis, pois são agregados benefícios de ambos os modelos, atendendo aos requerimentos específicos de cada projeto (CONBOY; FITZGERALD, 2010).

Esta nova abordagem foi motivada pelos desafios encontrados na implementação de modelos ágeis em organizações tradicionais, tais como a necessidade de mudança de cultura, resistência à mudança e tomada de decisão descentralizada (CAMPANELLI; PARREIRAS, 2015). Neste caso, as organizações deveriam implementar apenas as práticas ágeis que fizessem sentido para seu contexto organizacional específico e que contribuíssem para atingir seus objetivos estratégicos, mantendo, em paralelo, algumas práticas tradicionais.

O desafio das organizações é definir qual a melhor combinação entre as práticas tradicionais e as ágeis, quando adaptadas ao seu contexto, tirando proveito de ambas (BOEHM, 2002; CAMPANELLI; CAMILO; PARREIRAS, 2018). Os principais desafios na implementação dos modelos híbridos referem-se, portanto, à coexistência das práticas tradicionais com as ágeis e à interface entre áreas que adotam processos distintos. Para que este impacto seja minimizado e haja menor resistência durante sua implementação, a organização deve focar na utilização de práticas ágeis que requerem uma menor mudança em sua estrutura (GANDOMANI; ZULZALIL; GHANI; SULTAN, 2013). Portanto, é importante que, durante a adoção do modelo ágil, a equipe de implantação entenda o impacto causado às áreas externas que utilizam os processos não ágeis (MAHANTI, 2006; LINDVAL et al., 2004).

Como a implantação de modelos ágeis nas organizações muitas vezes é realizada primeiramente na área de desenvolvimento de software e, posteriormente, expandida para as demais áreas, com frequência haverá um período de coexistência de ambos os modelos, o que ocasiona alguns desafios. Diversos autores defendem que é possível implementar modelos ágeis em organizações grandes e tradicionais, desde que as práticas ágeis sejam customizadas e integradas ao ambiente organizacional tradicional (LINDVAL et al., 2004; 
WAARDENBURG; VLIET, 2013). Porém, também é necessário avaliar se a flexibilização das práticas ágeis não coloca em risco os valores necessários para a mudança de cultura, o que acabaria deixando de lado os principais benefícios deste modelo.

Boehm e Turner (2005) também preferem a construção do modelo híbrido por meio da seleção de práticas indispensáveis à necessidade do negócio, adaptadas aos processos atuais, sendo incrementadas gradativamente, de acordo com a prioridade, até chegar ao nível adequado de agilidade. Segundo os autores, a melhor forma para se determinar o nível de agilidade adequado para a organização é avaliar, para cada projeto, os riscos do excesso versus a deficiência de agilidade e comparar as consequências de cada extremo. Conforme mencionado por Chen, Ravichandar e Proctor (2016), não existem melhores práticas da implantação ágil (best practices) adaptáveis a todos os contextos, e sim melhores práticas para cada contexto organizacional específico (better practices).

\subsection{O PROCESSO DE TRANSIÇÃO ÁGIL}

Com o objetivo de atender às novas demandas dos clientes e de reduzir o time-tomarket no lançamento de seus produtos e serviços, muitas organizações estão transformando seus processos de desenvolvimento de software, passando de modelos tradicionais, baseados no planejamento, para modelos ágeis, que permitem uma maior adaptação ao dinamismo do mercado atual acelerado (COCKBURN; HIGHSMITH, 2001). Por este motivo, organizações consolidadas foram pressionadas a desenvolver seus projetos com maior flexibilidade, através da adoção de modelos ágeis (WAARDENBURG; VLIET, 2013).

No entanto, a implantação de modelos ágeis em organizações consolidadas não é garantia de sucesso. É necessário que haja uma adaptação aos seus valores de uma forma holística, considerando-se todos os aspectos da organização, tais como sua cultura e seus processos (BOEHM, 2002; DIKERT; PAASIVAARA; LASSENIUS, 2016). A adoção do modelo ágil pelas organizações de forma sustentável requer uma transformação de mentalidade (mindset) de toda a organização e não apenas uma mudança na forma de trabalho (TOLFO; WAZLAWICK; FERREIRA; FORCELLINI, 2009). Os desafios não se referem somente à aplicação das práticas ágeis no nível dos projetos, mas também à sua compatibilidade com os valores da organização, antes mesmo de iniciar a transição (LINDVAL et al,, 2004; TOLFO; WAZLAWICK; FERREIRA; FORCELLINI, 2009).

Boehm e Turner (2003) sugerem cinco fatores que devem ser considerados ao decidir se a organização se adapta melhor às práticas tradicionais ou às ágeis. São eles: 
- Tamanho do projeto - os pequenos são mais adaptáveis a modelos ágeis e os grandes, aos tradicionais;

- Criticidade ou tolerância a defeitos - os modelos ágeis são considerados mais tolerantes;

- Cultura - os modelos ágeis defendem a liberdade e o empoderamento da equipe, enquanto os tradicionais prezam por seguir políticas e procedimentos;

- Dinamismo - os modelos ágeis são mais adaptáveis tanto aos ambientes estáveis quanto aos dinâmicos, enquanto os tradicionais são os mais indicados para ambientes estáveis; e

- Pessoal - nos modelos ágeis, as equipes de desenvolvimento e do cliente estão totalmente dedicadas ao projeto; nos tradicionais, ao contrário, elas podem participar de vários projetos simultaneamente.

Kalus e Kuhrmann (2013) também sugerem a utilização de critérios para a adoção de práticas tradicionais ou ágeis. Eles incluem 49 itens, subdivididos nas 4 categorias apresentadas a seguir:

- Equipe - inclui itens como o tamanho, a distribuição e o conhecimento;

- Ambiente Interno - envolve o apoio da gestão, a definição de requerimentos e o custo do projeto;

- Ambiente Externo - inclui a quantidade de stakeholders do projeto, o tipo de contrato e o ambiente do cliente; e

- Objetivos - envolve a complexidade do projeto e o grau de inovação.

Estes critérios definem o grau de processos formais requeridos no projeto ou na organização e são determinantes para entender quais são as práticas mais adaptáveis para cada um dos critérios.

Campanelli e Parreiras (2015) adicionam dois outros critérios ao modelo de Kalus e Kuhrmann (2013). São eles:

- o Conhecimento Prévio, baseado na experiência anterior da organização quanto à customização de modelos de gestão de projetos; e

- o Nível de Maturidade que as organizações pretendem atingir depois da adoção de modelos ágeis. Aos quatro critérios supramencionados, eles adicionam outros como: Objetivos de Negócio, Tamanho da organização, Comunicação e Cultura.

Waardenburg e Vliet (2013) destacam a complexidade do ambiente de TI e o baixo envolvimento de negócios como desafios da implantação de modelos ágeis em organizações 
tradicionais. Eles também descrevem ações de contingência para lidar com estes desafios, sempre baseadas na colaboração e na comunicação entre as áreas ágeis e as não ágeis (LINDVAL et al., 2004; WAARDENBURG; VLIET, 2013).

Devido a esta disrupção em relação ao processo anterior, a transição do modelo de gestão de projetos tradicionais para o modelo ágil pode ser complexa e demorar para se consolidar na organização (GANDOMANI; ZULZALIL; GHANI; SULTAN; NAFCHI, 2013; GANDOMANI; ZULZALIL; GHANI; SULTAN, 2013; GANDOMANI et al., 2014; GANDOMANI; NAFCHI, 2015).

A falta de conhecimento quanto aos seus desafios faz com que esta transição seja ainda mais difícil de ser planejada, executada e gerenciada (NERUR; MAHAPATRA; MANGALARAJ, 2005; CONBOY; COYLE; XIAOFENG WANG; PIKKARAINEN, 2011; GANDOMANI; ZULZALIL; GHANI; SULTAN, 2013; GANDOMANI; NAFCHI, 2016; JOVANOVIĆ; MAS; MESQUIDA; LALIĆ, 2017). Para que possam gerenciar os riscos e definir ações de mitigação prévias, de acordo com o seu próprio contexto, é importante que as organizações se preparem para enfrentar certos desafios antes mesmo de darem início à transição. Tais desafios são classificados por alguns autores da literatura acadêmica de formas diferenciadas.

Nerur, Mahapatra e Mangalaraj (2005) os diferenciam entre os de Tecnologia, de Processos, de Pessoas e de Gestão. Jovanović et al. (2017) ressaltam a dificuldade de criar ambientes ágeis em organizações focadas na gestão tradicional. Gandomani, Zulzalil, Ghani e Sultan (2013) utilizam os mesmos critérios estabelecidos por Nerur, Mahapatra e Mangalaraj (2005), ou seja: Tecnologia, Processos, Pessoas e Gestão, porém em um contexto mais amplo da organização, em que estes quatro pilares estão baseados na estrutura organizacional, e a transformação para os valores ágeis suportada por um processo de Gestão de Mudança (Change Management). Espinosa-Curiel, Rodríguez-Jacobo, Vázquez-Alfaro, FernándezZepeda e Fajardo-Delgado (2018) classificam os desafios em: Pessoais, Sociais, Gerenciais, Organizacionais e Relacionados ao Projeto.

Gregory et al. (2016) os categorizam em sete grupos distintos:

- Limitações quanto à falta de informação ou interpretações equivocadas do novo modelo;

- Organizacionais, como a adoção da filosofia ágil em um ambiente não ágil;

- Cultura Organizacional;

- Equipes e Liderança; 
- Sustentabilidade, incluindo documentação e transferência de conhecimento;

- Escalonamento para projetos grandes; e

- Valor para o negócio.

\subsection{FRAMEWORKS PARA A TRANSIÇÃO PARA O MODELO ÁGIL}

A transição para o modelo ágil demanda tempo e esforço, pois afeta toda a organização e envolve mudanças no comportamento e na cultura da companhia. Não existe um modelo único para a transição ágil, no entanto, alguns autores sugerem a aplicação de frameworks, para que a transformação seja realizada com o menor impacto possível.

Chiniforooshan Esfahani (2012) e Sidky, Arthur e Bohner (2007) defendem que, antes de iniciar a transição para o modelo ágil, é necessário validar se ele é adaptável ao contexto da organização, tanto do ponto de vista estratégico, quanto do ponto de vista da aplicação das práticas ágeis.

O Strategic Agile pre-Adoption analysis Framework (SAAF) (CHINIFOROOSHAN ESFAHANI, 2012) propõe que a organização realize uma pré-avaliação por meio da aplicação de checklist, com a finalidade de verificar se está preparada para o modelo ágil e se há aderência aos novos processos. Este framework é indicado para a fase de pré-adoção das práticas ágeis, para avaliar os futuros impactos do modelo nos objetivos estratégicos da organização. Para que a transição seja eficiente, é necessário combinar uma série de práticas adaptadas à realidade da organização e compatíveis com seus processos atuais. Este processo é baseado em três fases:

- Inicialização, para construir o modelo estratégico da transição;

- Avaliação das possíveis práticas ágeis que serão adotadas pela organização e os impactos causados por cada uma delas; e

- Análise Estratégica, para identificar problemas do processo atual da organização e avaliar se serão resolvidos com a adoção das práticas sugeridas.

O framework proposto por Sidky, Arthur e Bohner (2007) recomenda a aplicação do Sidky Agile Measurement Index (SAMI). Trata-se de um indicador que mede o nível de agilidade da organização, de acordo com as práticas e princípios do Manifesto Ágil. Os autores sugerem, inclusive, um processo em quatro fases para identificar se a organização está preparada para mudar para o processo ágil e, então, aplicar o SAMI no nível do projeto ou da organização. Por fim, identificam quais práticas ágeis devem ser adotadas pela organização, 
considerando o objetivo identificado para o projeto e o nível de preparação da mesma para a transformação. Outra abordagem defendida pelos autores é a própria aplicação da filosofia ágil para implantar o modelo ágil, de forma gradual, iterativa e contínua.

Gandomani e Nafchi (2015) sugerem que a transição contemple os seguintes processos:

- Definição de indicadores para medir o valor esperado da transformação, baseados no valor do negócio;

- Iteração, de acordo com o método PDCA (Plan, Do, Check, Adjust);

- Melhoria contínua, com a implantação de algumas práticas, análise dos resultados e definição das próximas práticas a serem implantadas depois da adaptação das práticas anteriores;

- Transição gradual, priorizando a implementação das mudanças que causam maior impacto e aderência aos valores da companhia. Assim que esta mudança estiver consolidada, repetir o processo até que se atinja o grau de agilidade desejado. Esta abordagem de implementação gradual também auxilia na redução da resistência à mudança, uma vez que a implementação de novas práticas só é iniciada depois de a equipe estar adaptada às práticas atuais.

Outra abordagem dos frameworks refere-se à customização (tailoring) das práticas ágeis, de acordo com o contexto e com a estratégia da organização. Qumer e HendersonSellers (2008) propõem um processo de transição para o modelo ágil denominado ASSF Agile Software Solution Framework, que alinha o processo ágil com o que gera valor para a organização. Assim como Gandomani e Nafchi (2015), eles também entendem que a transição para o processo ágil não deve ser realizada integralmente e sim gradativamente ao longo do tempo, até que a organização tenha atingido o grau desejado de agilidade adaptado à sua cultura e ao seu modelo de governança. As organizações, em geral, não estão preparadas para a implementação da cultura ágil completa, por isso as práticas devem ser implementadas de forma incremental.

O framework supramencionado facilita a transição, alinhando o processo ágil à estratégia do negócio. Está baseado em dois passos: o primeiro, aplicando o Agile Toolkit, para avaliar o grau de agilidade nos processos de desenvolvimento de software da organização; e o segundo, utilizando um processo para suportar o processo de adoção do modelo ágil chamado Agile Adoption and Improvement Model (AAIM). O AAIM provê um roadmap para a implementação das práticas ágeis de acordo com o contexto da organização 
obtido na fase de avaliação. Primeiramente, avalia-se a organização e, a seguir, seleciona-se quais práticas devem ser implementadas, de forma gradual, para obter uma transição de sucesso e eficiente.

O framework proposto por Cao et al. (2009) também aborda o conceito de customização, investigando o modo como adaptar as práticas ágeis a diferentes contextos organizacionais. Neste modelo, as práticas sugeridas no processo padrão são adicionadas, excluídas ou modificadas de modo a se alinharem com as necessidades da organização, utilizando-se processos customizados (tailored processes). Por exemplo, propondo um nível intermediário de formalidade entre o ágil e o tradicional, resultando assim em um modelo híbrido, que atenda às necessidades da alta gerência e também incorpore alguns princípios ágeis.

Boehm e Turner (2003) defendem um modelo híbrido de modelos tradicionais e ágeis, tirando proveitos das vantagens de cada qual e considerando os objetivos da organização. Eles entendem que, com esta combinação de modelos de forma customizada, haverá uma melhor adesão da organização ao processo. O objetivo principal é satisfazer o cliente final e os stakeholders, com o modelo mais adequado. Ou seja, os modelos são importantes, mas, o mais importante é lidar com as pessoas, com as culturas, com a comunicação e com as expectativas da gestão.

Boehm e Turner (2003) também propõem a realização de um assessment inicial, realizado com todos os stakeholders (alta gestão, áreas de produto, marketing e outras áreas internas, clientes, fornecedores e outros parceiros estratégicos que participam do fluxo de desenvolvimento de software), informando o estado atual e o desejado. Depois da realização deste assessment, a equipe deverá compreender o gap entre o estado atual e o desejado e definir um plano de ação para obter o resultado almejado. O plano deve incluir treinamentos, coaching e melhoria na comunicação.

A alta direção e a equipe responsável pela transformação devem deixar claro para todos os membros da organização qual é o objetivo da mudança de processo para que haja o envolvimento total das equipes. Quanto mais as equipes sentirem-se parte do processo, maior será o seu engajamento. Durante a implementação, é importante também mapear o progresso da transformação, comparado ao plano de ação inicial. Este tracking deve ser informado a todos os membros da organização e deve ser solicitado o feedback. O processo deve ser iterativo, promovendo melhoria contínua até que esteja adaptado ao contexto e ao momento atual da organização. 
Campanelli, Camilo e Parreiras (2018) também ressaltam a customização das práticas ágeis e a implementação gradual do processo, gerando um modelo aderente às necessidades, aos valores e à cultura da organização. Este processo pode ser realizado mantendo-se algumas práticas tradicionais já utilizadas pela organização e incrementando-as com as práticas ágeis, priorizando as que geram maior valor para o negócio. Para apoiar este processo, os autores desenvolveram o SAAP - Strategic Analysis for Agile Practices, um framework que associa os objetivos de negócio da organização com a adoção de práticas ágeis e, posteriormente, define um modelo para selecionar as melhores práticas baseadas nas características dos projetos.

Pikkarainen, Salo, Kuusela e Abrahamsson (2012) propõem um modelo que pode ser usado na implementação e na melhoria contínua do processo ágil que inclui quatro fases:

- Na primeira, devem ser definidos os objetivos da transição, tais como o motivo da implantação do modelo ágil, o nível de agilidade desejado e os riscos da transição. Nesta fase também são identificadas as práticas ágeis a serem implementadas para atingir tais objetivos;

- Na segunda, a organização deve planejar a implementação, priorizando as práticas a serem aplicadas, selecionando o projeto piloto e as oportunidades de melhoria de processos na organização;

- Na terceira, o novo modelo deve ser implementado. Os projetos piloto são iniciados e as práticas ágeis selecionadas são aplicadas e avaliadas, de forma iterativa e baseadas no feedback da equipe do projeto;

- Na quarta e última fase, é feita a análise dos resultados da implantação, tomando como base o feedback obtido no projeto piloto, além da melhoria contínua dos processos de forma cíclica.

Com base nestes frameworks, contata-se que a implementação de modelos ágeis causa um grande impacto na cultura das organizações. Por isso, elas estão preferindo utilizar modelos híbridos, implementando apenas algumas das práticas que se encaixam no seu contexto organizacional, ao invés de adotarem o modelo ágil completo, o que demandaria uma grande mudança organizacional para adaptação. Além do mais, as organizações devem identificar as práticas ágeis prioritárias a serem implementadas, de acordo com o valor que cada uma delas gera para o próprio negócio, e implementá-las gradual e iterativamente, na medida em que a equipe for se adaptando. A fase de planejamento da transição é essencial 
para definir os objetivos da transição; selecionar os projetos piloto e as práticas ágeis que serão priorizadas; e criar um awareness em toda a organização quanto a este novo processo. 


\section{METODOLOGIA DA PESQUISA}

Para atingir os objetivos propostos, foi realizada uma Pesquisa Qualitativa Exploratória. Almeida, Francesconi e Fernandes (2019, p. 51-59) explicam que a busca pelo comportamento de determinada teoria em relação à prática pode vir a se tornar uma nova teoria. Eles caracterizam a pesquisa qualitativa: quanto à amostra, com um número de entrevistados geralmente baixo; e quanto à coleta de dados, realizadas por meio de entrevistas sobre o assunto tratado. Eles afirmam também que a pesquisa exploratória "é utilizada quando o pesquisador quer investigar um assunto ainda pouco explorado ou ainda não precisamente definido".

Tais conceitos permitem afirmar que a presente dissertação se trata de uma pesquisa qualitativa exploratória, com coleta de dados em fontes primárias e secundárias. Os dados secundários para a criação do instrumento de pesquisa foram obtidos por meio de Revisão Sistemática de Literatura, realizada predominantemente na base de dados Scopus e complementada com derivações no Google Acadêmico.

Visando a obter informações relevantes acerca do questionamento inicial e, assim, atingir os objetivos propostos e conseguir desenvolver a pesquisa, também se valeu de fontes primárias para coleta de dados, por meio de entrevistas semiestruturadas, conforme procedimentos descritos a seguir. A entrevista semiestruturada foi escolhida em função do caráter qualitativo e exploratório do objeto de pesquisa, em consonância com Almeida, Francesconi e Fernandes (2019, p. 73) que, ao mencioná-la, afirmam: durante as entrevistas semiestruturadas "são apresentados previamente os principais pontos, mas dando liberdade ao entrevistado para discorrer de forma livre sobre outros pontos não solicitados pelo roteiro".

Dessa forma, a presente pesquisa foi realizada em três fases, assim divididas: Revisão Sistemática da Literatura (RSL), Coleta de Dados Primários e Análise dos Resultados, conforme demonstra a Figura 1, a seguir. 
Figura 1 - Metodologia da Pesquisa

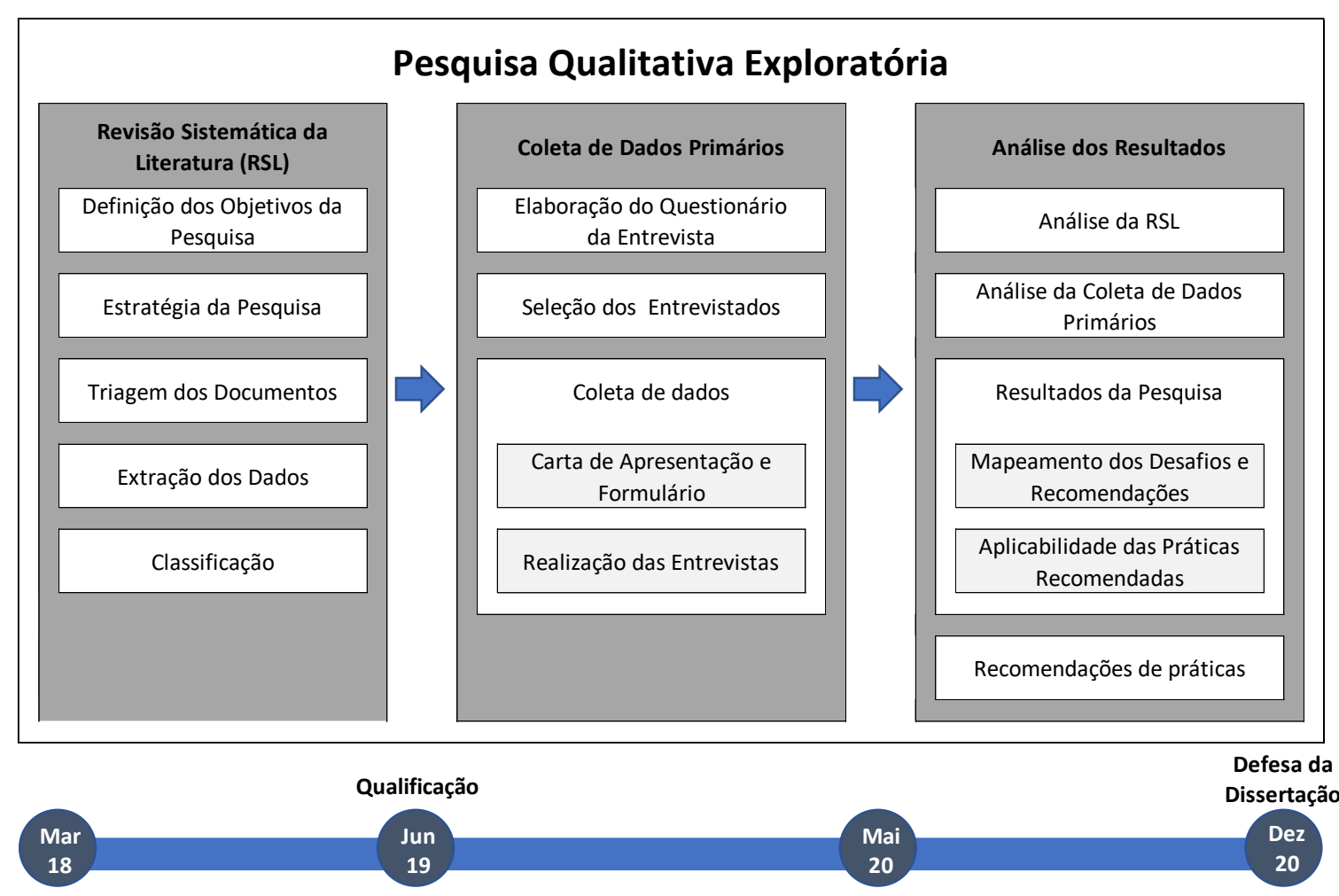

Fonte: Figura elaborada pela autora.

\subsection{REVISÃO SISTEMÁTICA DA LITERATURA (RSL)}

A Revisão Sistemática da Literatura (RSL), realizada entre março de 2018 e junho de 2019, teve como objetivo compreender como o processo de transição dos modelos de gestão de projetos tradicionais para os ágeis vem sendo abordado pela literatura acadêmica. A pesquisa baseou-se no processo de RSL, descrito por Kitchenham (2004), devido à sua aderência com a área de Engenharia de Software e compreendeu cinco passos, a saber: Definição dos Objetivos da Pesquisa, Estratégia da Pesquisa, Triagem dos Documentos, Extração dos dados e Classificação, os quais são descritos a seguir.

\subsubsection{Definição dos Objetivos da Pesquisa}

Na primeira etapa da RSL buscou-se responder à pergunta inicial da presente pesquisa: “Quais são as principais práticas que facilitam a transição do modelo tradicional para o ágil na gestão de projetos de desenvolvimento de software?" e, desse modo, atingir o objetivo principal estabelecido: “elaborar um conjunto de práticas recomendadas, a serem adotadas 
pelas organizações, para facilitar o processo de transição do modelo tradicional para o ágil na gestão de projetos de desenvolvimento de software”.

\subsubsection{Estratégia da Pesquisa}

A pesquisa bibliográfica foi realizada na base de dados Scopus, utilizando-se o idioma inglês. As quatro palavras-chave utilizadas na busca foram: Agile Adoption Challenges; Agile Transformation Process; Agile Process Tailoring; e Agile Transition Framework. Foram filtrados artigos das áreas de "Computer Science", "Engineering" e "Business, Management and Accounting". Não foi estabelecido nenhum filtro de data, ou seja, não foram definidas balizas temporais, dado que se trata de um tema relativamente recente e, portanto, todas as publicações ocorreram a partir do Manifesto Ágil (BECK et al., 2001), em 2001. A busca resultou em 784 documentos $(\mathrm{N}=784$, Fase 1), conforme demonstra a Figura 2, a seguir.

\subsubsection{Triagem dos Documentos}

A partir da aplicação de um novo filtro, em função da tipologia do documento "article" e da tipologia da fonte "journal", obteve-se o resultado de 158 artigos $(\mathrm{N}=158$, Fase 2) demonstrado no Quadro 2 e Figura 2 a seguir.

O Quadro 1 abaixo exemplifica a pesquisa realizada a partir da palavra-chave "Agile Transformation Process". A mesma forma de busca foi realizada também para as demais palavras-chave, alterando-se apenas a linha do título e do resumo.

Quadro 1 - Exemplo de Pesquisa a partir da palavra-chave "Agile Transformation Process"

TITLE-ABS-KEY (Agile AND Transformation AND Process )

AND ( LIMIT-TO ( SRCTYPE, "j" ) )

AND ( LIMIT-TO ( SUBJAREA, "COMP" ))

OR LIMIT-TO ( SUBJAREA, "ENGI" )

OR LIMIT-TO ( SUBJAREA, "BUSI" )

AND ( LIMIT-TO ( DOCTYPE, "ar" ))

AND ( LIMIT-TO ( LANGUAGE , "English" ) )

Fonte: Quadro elaborado pela autora com base na pesquisa realizada na base de dados Scopus.

A aderência de cada artigo aos objetivos da pesquisa foi avaliada a partir da leitura do Título e do Resumo (Abstract). Realizou-se, então, uma triagem inicial, obtendo-se um total 
de 19 artigos ( $\mathrm{N}=19$, Fase 3), excluídas as duplicidades, conforme demonstram o Quadro 2 e a Figura 2, a seguir.

Quadro 2 - Triagem dos documentos por palavras-chave

\begin{tabular}{ccc}
\hline Palavras-Chave & $\begin{array}{c}\text { Artigos Resultantes } \\
\text { (Fase 2) }\end{array}$ & $\begin{array}{c}\text { Após Triagem Inicial } \\
\text { (Fase 3) }\end{array}$ \\
\hline Agile Adoption Challenges & 47 & 9 \\
Agile Transformation Process & 78 & 4 \\
Agile Process Tailoring & 12 & 1 \\
Agile Transition Framework & 21 & 5 \\
\hline Total & $\mathbf{1 5 8}$ & $\mathbf{1 9}$ \\
\hline
\end{tabular}

Fonte: Quadro elaborado pela autora.

\subsubsection{Extração dos Dados}

Depois da leitura atenta de todos os 19 artigos resultantes da triagem inicial (Fase 3), foram excluídos os que não tinham aderência à pergunta em questão, como, por exemplo, os estudos que não abordavam a transição ágil; os estudos de modelos ágeis em indústrias que não incluíam o desenvolvimento de software (tais como manufatura); os estudos de uma metodologia ágil específica; ou outros temas técnicos não relacionados (como, Devops, arquitetura, cloud etc.). Foram selecionados artigos resultantes de pesquisas qualitativas e quantitativas, estudos de caso empíricos ou ainda outras RSL relacionadas com o tema proposto.

Complementando a bibliografia, também foram selecionados outros artigos adicionais que, embora não tenham resultado diretamente da pesquisa prévia, foram citados nos artigos lidos, constando como referências relevantes. A busca por estes artigos complementares foi realizada via Google Acadêmico, mediante a inserção do título e do autor. Ao final deste processo, foram selecionados, no total, 36 artigos $(\mathrm{N}=36$, Fase 4$)$ relevantes para o presente estudo, conforme detalhado na Figura 2. 
Figura 2 - Processo de triagem e seleção de artigos

\begin{tabular}{|c|c|c|}
\hline Fase 1 & $\begin{array}{c}\text { Busca das palavras-chave na base Scopus } \\
\qquad \text { Critérios de inclusão: } \\
\text { Palavras-chave = "Agile Adoption Challenges"; } \\
\text { "Agile Transformation Process"; "Agile Process } \\
\text { Tailoring"; "Agile Transition Framework" } \\
\text { Idioma = "Inglês" } \\
\text { Áreas = "Computer Science"; "Engineering"; } \\
\text { "Business, Management and Accounting" }\end{array}$ & $N=784$ \\
\hline Fase 2 & $\begin{array}{l}\text { Filtro pelo tipo de documento e de fonte } \\
\text { Critérios de inclusão: } \\
\text { Tipo de documento = "article" } \\
\text { Tipo de fonte = "journal" }\end{array}$ & $N=158$ \\
\hline Fase 3 & $\begin{array}{l}\text { Análise da aderência ao tema da pesquisa } \\
\text { Critérios de inclusão: } \\
\text { Título e resumo (abstract) dos artigos } \\
\text { relacionados aos objetivos da pesquisa }\end{array}$ & $N=19$ \\
\hline Fase 4 & $\begin{array}{l}\text { Análise dos artigos e inclusão de referências } \\
\text { cruzadas } \\
\text { Critérios de inclusão: } \\
\text { Leitura dos artigos obtidos e identificação de } \\
\text { artigos adicionais citados como referências } \\
\text { relevantes } \\
\end{array}$ & $N=36$ \\
\hline
\end{tabular}

Fonte: Figura elaborada pela autora.

\subsubsection{Classificação}

Cada um dos artigos selecionados foi, então, analisado em função dos principais conceitos abordados, sintetizando-os conforme os desafios encontrados durante o processo de transição para o modelo ágil de gestão de projetos. Posteriormente, tais desafios foram classificados por similaridade, sendo identificadas quatro categorias de pesquisa: Processos, Pessoas, Gestão e Organização, a partir de uma adaptação da versão de Nerur, Mahapatra e Mangalaraj (2005) (Tecnologia, Processos, Pessoas e Gestão). Os desafios e recomendações encontrados na literatura foram então agrupados em função de cada uma dessas quatro 
categorias estabelecida, sendo que cada desafio foi considerado como uma Unidade de Análise (UA), totalizando, então, 25 UAs. A descrição de cada uma delas encontra-se no subitem 4.1 ANÁLISE DOS RESULTADOS DA REVISÃO SISTEMÁTICA DA LITERATURA (RSL).

\subsection{PROCEDIMENTOS PARA A COLETA DE DADOS PRIMÁRIOS}

A coleta de dados primários foi realizada por meio de entrevistas semiestruturadas. As etapas realizadas apresentam-se a seguir.

\subsubsection{Elaboração do Questionário da Entrevista}

A partir da definição das Unidades de Análise (UAs) durante a fase inicial da RSL, foi elaborado o questionário de entrevistas a serem realizadas individualmente com cada um dos entrevistados. Foi definida uma questão por UA, a qual está mencionada na coluna “Questionário da Entrevista” nos APÊNDICES B - DESAFIOS DE PROCESSOS, C DESAFIOS DE PESSOAS, D - DESAFIOS DE GESTÃO e E - DESAFIOS DA ORGANIZAÇÃO.

Para reduzir o escopo e a duração das entrevistas, durante a realização da mesma algumas questões referentes a UAs específicas foram desconsideradas. Por isso, em alguns casos, ao fazer a análise, na coluna "Questionário da Entrevista" consta a informação "na entrevista, não foi incluída nenhuma questão específica quanto a este item”.

Posteriormente, este questionário foi estruturado de forma a seguir uma ordem lógica durante a entrevista, sendo dividido em três partes: Processo de Transição para o Modelo Ágil, Impactos Humanos da Transição e Resultados da Transição, conforme pode ser observado no APÊNDICE H - QUESTIONÁRIO DA ENTREVISTA.

Também foi elaborado um formulário incluindo questões genéricas referentes à organização, ao entrevistado, aos projetos e à transição ágil, para a identificação dos respectivos perfis, conforme consta no APÊNDICE G - COLETA DE DADOS PRIMÁRIOS - FORMULÁRIO INICIAL. 


\subsubsection{Seleção dos Entrevistados}

Considerando-se a natureza exploratória da presente pesquisa e a necessidade de coleta de dados primários para melhor aproximação da realidade atual, foram selecionados, dentre a rede de relacionamento da autora, dez entrevistados que trabalhassem em organizações nacionais ou multinacionais, que já tivessem passado por processos de transição ágil, mesmo ainda não concluídos, e que se dispusessem a responder as perguntas da entrevistadora.

Ademais, a função exercida pelos entrevistados escolhidos deveria estar relacionada com o conteúdo de gestão de projetos de desenvolvimento de softwares, mas sem uma nomeação ou um cargo específico, desde que sua experiência com gestão de projetos fosse superior a 5 anos, incluindo necessariamente vivência com a transição para o modelo ágil. A faixa etária não foi determinante para elegê-los, assim como não foi determinante o segmento de atuação da organização para qual trabalhassem. Em duas organizações analisadas foram entrevistados dois funcionários, o que justifica serem 10 entrevistados e oito organizações.

No que tange à organização, também não houve nenhuma delimitação quanto ao porte e nem quanto ao tempo de existência da mesma, embora a probabilidade tenha sido que tais organizações tivessem mais de dez anos, uma vez que a maioria das startups já nasceu com o conceito de modelo ágil no desenvolvimento de seus produtos de tecnologia.

O anonimato tanto da organização quanto do funcionário foi assegurado, sendo as oito organizações identificadas por letras (A, B, C e assim sucessivamente) e os funcionários, por números (E1, E2, E3 e assim sucessivamente, até E10). Foram divulgados apenas alguns dados básicos não comprometedores.

O perfil dos entrevistados e das organizações está descrito abaixo e se apresenta detalhado no APÊNDICE F - PERFIL DOS ENTREVISTADOS E DAS RESPECTIVAS ORGANIZAÇÕES.

\subsubsection{Perfil dos entrevistados}

O perfil dos dez entrevistados selecionados pode ser resumido da seguinte maneira:

- Gênero: sete dos entrevistados são do gênero feminino e três, do masculino;

- Faixa etária: quatro dos entrevistados pertencem à faixa etária entre 30 e 39 anos; 5, entre 40 e 49 anos; e um, entre 50 e 59 anos; 
- Cargo: sete entrevistados pertencem ao nível operacional, com os cargos de Gerente de Projetos, Scrum Master, Product Owner, Agile Coach e Agile Master; um, pertence ao nível de média gestão, com o cargo de Coordenador de Projetos; e dois possuem cargos executivos como Gerente do Escritório de Projetos e Digital Transformation Leader.

- Tempo de experiência em projetos: todos os entrevistados possuíam de 10 a 17 anos de experiência em gestão de projetos, com uma média de 13 anos.

- Tempo de experiência ágil: todos os entrevistados possuíam de 1 a 8 anos de experiência em projetos ágeis, com uma média de 4 anos.

\subsubsection{Perfil das organizações}

Quanto ao perfil das oito organizações, constatamos o seguinte:

- Segmento: quatro das organizações analisadas pertencem ao segmento Financeiro (2 Bancos, 1 Adquirência e 1 Mercado de Capitais); duas, ao de Tecnologia da Informação (TI); uma, de Telecomunicações; e uma, de Varejo;

- Nacionalidade: Seis das organizações analisadas são nacionais e duas, multinacionais;

- Porte: 2 das organizações possuem menos de 1.000 funcionários; 3, de 1.000 a 10.000; e 3, mais de 10.000;

- Início da Transição: uma das organizações iniciou a transição para o modelo ágil em 2015; uma, em 2017; cinco, em 2018; e uma, em 2019;

- Duração da Transição: a duração da transição variou entre 1 e 5 anos, com uma média de 2 anos (caso não tivesse sido concluída, considerou-se a duração até o momento);

- Conclusão da Transição: os entrevistados de cinco organizações consideraram que a transição ainda não foi concluída e os entrevistados de apenas três delas consideraram que a transição foi concluída.

\subsubsection{Realização das Entrevistas}

A coleta dos dados primários ocorreu por meio de entrevistas, realizadas em duas etapas, entre julho de 2019 e maio de 2020. Na primeira etapa, foram enviados ao 
entrevistado, via e-mail, a Carta de Apresentação (APÊNDICE I - CARTA DE APRESENTAÇÃO PARA REALIZAÇÃO DA ENTREVISTA) e o Formulário Inicial (APÊNDICE G - COLETA DE DADOS PRIMÁRIOS - FORMULÁRIO INICIAL). A Carta de Apresentação incluía os objetivos da pesquisa, o procedimento para a realização da mesma e o termo de consentimento para gravação e futura transcrição. A garantia do anonimato e de utilização de seu conteúdo somente para fins estritamente acadêmicos foi claramente informada. Foi solicitado ao eventual entrevistado que, caso estivesse de acordo com a realização da pesquisa, o Formulário Inicial deveria ser devolvido (também via e-mail) antes da data prevista para a realização da entrevista, que ocorreria em dada a ser agendada conforme disponibilidade do mesmo.

Na segunda etapa, foi realizada a coleta de dados primários, por meio de entrevista com perguntas semiestruturadas. Três entrevistas foram realizadas de forma presencial; as demais, online, por meio de videoconferência. A duração de cada uma delas foi de aproximadamente uma hora, tendo sido abordados os detalhes da transição e das transformações ocorridas nos processos, nas equipes e na cultura da organização. O principal objetivo desta etapa foi coletar dados e percepções dos entrevistados quanto à sua vivência durante o processo de transição para o modelo ágil.

As entrevistas foram gravadas e posteriormente transcritas pela própria autora, para auxiliar na análise dos resultados, conforme descrito a seguir. Na presente dissertação, o conteúdo dessas entrevistas não consta na íntegra, apenas alguns recortes (identificados segundo o entrevistado e mencionados entre aspas), que foram compilados para possibilitar a análise e transcritos exatamente como mencionados, ou seja, com algumas pequenas repetições, erros gramaticais ou mesmo com o uso de termos não acadêmicos, característicos da linguagem informal e típicos da oralidade.

\subsubsection{Análise da Coleta de Dados Primários}

A análise da coleta de dados primários obtidos por meio de entrevistas foi realizada em etapas, a saber:

a) Leitura integral das transcrições das entrevistas, para compreensão da visão geral de cada entrevistado;

b) Elaboração de uma matriz com a tabulação das respostas dos entrevistados para cada uma das questões, incluindo o conteúdo completo de todas as entrevistas; 
c) Classificação e sumarização das respostas de todos os entrevistados para cada uma das questões propostas, identificando a quantidade de ocorrências de cada classificação;

d) Identificação das questões da entrevista associadas a cada uma das UAs. Quando necessário, criação de Subunidades de Análise, podendo estar relacionadas com uma questão específica ou como uma subdivisão da própria questão advinda das respostas dos entrevistados.

e) Criação de um quadro para cada UA, com a respectiva subunidade de Análise, quando houver, contendo: mensagem principal (apresentação do principal comentário do entrevistado referente à questão da entrevista); interpretação da mensagem principal (interpretação da autora referente à mensagem principal do entrevistado); mensagem associada (comentários dos entrevistados associados à questão da entrevista, quando houver); e interpretação da mensagem associada (interpretação da autora referente à mensagem associada do entrevistado, quando houver).

f) Análise geral da autora quanto à Unidade ou Subunidade de Análise, considerando as respostas dos entrevistados para cada uma das questões específicas, bem como sua associação com as demais UAs. Esta análise está presente nos quadros, identificada com MP, iniciais do nome da autora.

O resultado desta análise foi apresentado detalhadamente no Subitem 4.2 ANÁLISE DOS RESULTADOS DA COLETA DE DADOS PRIMÁRIOS.

\subsection{PROCEDIMENTOS PARA ANÁLISE DOS RESULTADOS}

Para atingir os objetivos propostos, foi realizada uma análise comparativa entre os conceitos definidos pela literatura acadêmica, extraídos na RSL, e as práticas adotadas pelas organizações, obtidas por meio das entrevistas na fase da coleta de dados primários. A finalidade foi identificar quais das recomendações propostas pela literatura estavam sendo efetivamente aplicadas pelas organizações.

Os procedimentos para análise dos resultados ocorreram conforme descrito nos subitens a seguir.

\subsubsection{Mapeamento dos Desafios e Recomendações}

O objetivo desta fase foi definir quais procedimentos seriam necessários para mapear a percepção dos entrevistados em relação aos principais desafios e recomendações observados 
durante a transição ágil das organizações, de forma a atender aos seguintes objetivos específicos da presente pesquisa:

a) Identificar os desafios encontrados pelas organizações na transição do modelo tradicional para o ágil;

b) Identificar as recomendações propostas pelas organizações para superar os desafios da transição.

Para atingir tais objetivos foram elaboradas duas questões específicas, presentes no questionário de entrevista, não estando associadas a nenhuma Unidade de Análise. São elas:

Q25: Quais foram os maiores desafios da transformação ágil?

Q30: Qual recomendação você daria para as organizações que estão iniciando o processo de transformação ágil?

As respostas dos entrevistados para tais questões foram mapeadas, sendo, inclusive, identificada a quantidade de ocorrências de cada uma delas. O resultado deste mapeamento está descrito no Subitem 4.3 MAPEAMENTO DOS DESAFIOS E RECOMENDAÇÕES COM BASE NA COLETA DE DADOS e pode ser observado no Quadro 39.

\subsubsection{Análise da Aplicabilidade das Práticas Recomendadas pela Literatura Acadêmica}

O objetivo da análise da aplicabilidade das práticas recomendadas foi atender ao terceiro objetivo específico de pesquisa:

c) Verificar se as organizações analisadas estão aplicando as práticas de transição ágil recomendadas pela literatura acadêmica.

Para isso, foi criado um quadro adicional (Quadro 41) que permite uma visualização mais clara da comparação entre as recomendações da literatura acadêmica e sua aplicação nas organizações analisadas referentes a cada uma das UAs. Nele foi incluída também a análise da coleta de dados realizada pela autora. O resultado desta análise apresenta-se no Subitem 4.4 APLICABILIDADE DAS PRÁTICAS RECOMENDADAS PELA LITERATURA ACADÊMICA.

\subsubsection{Análise das Práticas Recomendadas}

Nesta fase, foi realizada a sumarização dos principais dados obtidos tanto pela literatura acadêmica quanto pela coleta de dados primários, de forma a atender ao objetivo principal de pesquisa, a saber: "Elaborar um conjunto de práticas recomendadas, a serem 
adotadas pelas organizações, para facilitar o processo de transição do modelo tradicional para o ágil na gestão de projetos de desenvolvimento de software”.

O resultado desta análise apresenta-se no subitem 4.5 PRÁTICAS RECOMENDADAS e pode ser visualizado no Quadro 41. 


\section{ANÁLISE DOS RESULTADOS}

\subsection{ANÁLISE DOS RESULTADOS DA REVISÃO SISTEMÁTICA DA LITERATURA (RSL)}

Conforme mencionado anteriormente, a RSL resultou na identificação de 25 Unidades de Análise (UAs), de acordo com os desafios observados na literatura. Estas UAs foram divididas entre quatro categorias de pesquisa, definidas pela autora (Processos, Pessoas, Gestão e Organização), com base na adaptação da versão de Nerur, Mahapatra e Mangalaraj (2005). A distribuição das UAs entre essas quatro categorias de pesquisa é apresentada a seguir:

- Desafios de Processos: 11 UAs (de 1 a 11), conforme detalhado no APÊNDICE B - DESAFIOS DE PROCESSOS;

- Desafios de Pessoas: 8 UAs (de 12 a 19), conforme detalhado no APÊNDICE C - DESAFIOS DE PESSOAS;

- Desafios de Gestão: 2 UAs (20 e 21), conforme detalhado no APÊNDICE D DESAFIOS DE GESTÃO;

- Desafios da Organização: 4 UAs (de 22 a 25), conforme detalhado no APÊNDICE E - DESAFIOS DA ORGANIZAÇÃO.

A seguir são apresentados os resultados obtidos pela RSL, sumarizados de acordo com sua categoria e UA.

\subsubsection{Desafios de Processos na Análise da RSL}

Os Desafios de Processo de Análise da RSL estão relacionados com a aplicação das novas práticas ágeis e com sua respectiva adaptação durante a transição. A sumarização destes desafios está descrita no APÊNDICE B - DESAFIOS DE PROCESSOS (UAs de 1 a 11).

\subsubsection{Transição Big Bang - RSL (UA 1)}

A Transição Big Bang (ou transição total) do modelo tradicional para o modelo ágil pode gerar impactos nos projetos, devido à necessidade de rápida adaptação da equipe aos novos processos e à cultura ágil. Uma das recomendações é, inclusive, que a transição ocorra 
de forma gradual e iterativa, priorizando a implantação das práticas ágeis que possuem maior aderência aos objetivos organizacionais e à cultura vigente. O ideal é que a organização implemente, inicialmente, um projeto piloto para avaliar a integração entre os processos tradicionais e os ágeis. À medida que os processos forem sendo alinhados e que seja obtido o feedback dos projetos iniciais, passa-se, então, a expandi-los para os demais projetos (COHN; FORD, 2003; DIKERT; PAASIVAARA; LASSENIUS, 2016).

\subsubsection{Preparação para a transição ágil - RSL (UA 2)}

No que tange à transição para o modelo ágil, as organizações devem ter não só um motivador claro para que ela ocorra, como também uma justificativa para a adoção deste modelo. As organizações devem estar cientes das mudanças de mentalidade e de cultura que tal modelo irá requerer. Diversos autores sugerem, inclusive, a adoção de um framework que inclua uma fase de assessment, para determinar se a organização realmente está preparada para esta mudança e para apoiar a execução do processo de transição (CHINIFOROOSHAN ESFAHANI, 2012; GANDOMANI; NAFCHI, 2015; SIDKY; ARTHUR; BOHNER, 2007).

\subsubsection{Resultados da transição - RSL (UA 3)}

Assim como a transição do modelo tradicional para o modelo ágil gera transformações nos processos e na cultura da equipe, ela também pode impactar os resultados. Neste sentido, a curva de aprendizado dos membros da equipe deve ser levada em consideração, até que estejam adaptados ao novo modelo, podendo, eventualmente, haver redução na produtividade no início desse processo. A organização também deve adotar um processo de melhoria contínua, priorizando as práticas com maior aderência à organização e evoluindo na medida em que a equipe for se adaptando às novas práticas (BOEHM; TURNER, 2003; GANDOMANI; NAFCHI, 2015; SIDKY; ARTHUR; BOHNER, 2007).

\subsubsection{Processos organizacionais - RSL (UA 4)}

Outro impacto ocorrido durante a implantação de modelos ágeis pelas organizações tradicionais é a integração dos projetos ágeis com o ambiente, com a cultura e com os processos tradicionais que pode gerar retrabalho, devido à utilização simultânea de ambos os processos, por exemplo, pela necessidade de gerar documentação em ambos os modelos. Este 
retrabalho pode, inclusive, levar à redução da agilidade do projeto. Deve-se ponderar, inclusive, se a adoção do modelo ágil não desperdiçará os processos tradicionais já estabelecidos entre as áreas e que estão funcionando bem (BOEHM; TURNER, 2005; MAHANTI, 2006).

Pelos motivos expostos, antes do início do projeto, a organização deve necessariamente definir quais processos ágeis serão adotados e alinhar com as distintas áreas quanto aos respectivos entregáveis. A organização pode começar a adotar o modelo ágil implantando, primeiramente, um projeto piloto, integrando os processos ágeis com os outros já existentes e, depois da definição dos entregáveis, passar a usar o modelo ágil nos demais projetos (BOEHM; TURNER, 2005; MAHANTI, 2006). Ao implementar este piloto, é interessante escolher projetos menores e de curta duração, para que se possa obter resultados rápidos, medir o impacto causado nos processos tradicionais e colher feedback da equipe e da organização. Tal avaliação seria fundamental para a melhoria dos projetos futuros.

\subsubsection{Estimativas - RSL (UA 5)}

Pelo fato de os requerimentos do projeto não serem completamente conhecidos antes do início de seu desenvolvimento, a equipe não consegue fornecer à alta gestão da organização nenhuma estimativa nem de custo e nem de prazo referentes à implementação do projeto. Para contornar o desconforto da gestão em relação a isso, uma alternativa é apresentar, no início do projeto, uma estimativa em alto nível e aprovar o investimento inicial levando-a em consideração. A cada detalhamento do projeto, esta estimativa poderá ser revisada e, caso necessário, poderá ser discutido o investimento adicional. Quando as equipes estiverem acostumadas com o desenvolvimento ágil e conhecerem o negócio da organização, irão se tornar suficientemente maduras para realizar estimativas cada vez mais precisas (CAO et al., 2009; COHN; FORD, 2003).

\subsubsection{Relatórios de status - RSL (UA 6)}

Como o modelo ágil não prevê a elaboração de relatórios de status formais, tais como os baseados em percentuais de execução de escopo, de prazo e de custo dos modelos tradicionais, uma forma de acompanhar o projeto e de avaliar se ele realmente está sendo executado de acordo com a expectativa da gestão é definindo alguns milestones, adaptados ao modo iterativo do modelo ágil. A partir desta definição e levando-se em consideração os 
milestones, a equipe deve criar um modelo básico de relatório de status para apresentar à alta gestão, incluindo também um comentário geral sobre o projeto e alguns indicadores de sua evolução (COHN; FORD, 2003). Desta forma, a gestão se sentirá mais confortável em acompanhar o status do projeto durante sua execução (BOEHM; TURNER, 2005).

Outra forma de medir o progresso do projeto é avaliando a performance da equipe, por meio do gráfico de burndown, previsto no modelo Scrum. Este gráfico mede o evolução do desenvolvimento em relação ao planejado para cada intervalo de tempo fixo (SCHWABER; SUTHERLAND, 2017). Além disso, a cada entrega de software funcionando, os usuários e os gestores podem ter uma medida importante a respeito do andamento do projeto, podendo, inclusive, dar o seu feedback em relação à qualidade da entrega, até mesmo antes da conclusão final do projeto (BOEHM; TURNER, 2005).

\subsubsection{Contratos - RSL (UA 7)}

Devido à ausência de planejamento e de escopo detalhados no início do projeto, é difícil estimar, com precisão, nesta fase, quais serão o prazo e o custo totais do mesmo. Por este motivo, para que se possa identificar os impactos do modelo ágil e redefinir as métricas e os marcos de progresso, assim como as novas formas de contratação e pagamento, devem ser reavaliados os contratos com clientes ou fornecedores externos (BOEHM; TURNER, 2005). Uma das alternativas é a contratação da equipe por período (ao invés de escopo fechado), definindo o que será executado no período em questão, de acordo com a priorização de funcionalidades.

\subsubsection{Comunicação - RSL (UA 8)}

Em relação à documentação do projeto, o modelo ágil foca mais na comunicação, incrementando, entre os membros da equipe, a comunicação formal, informal, verbal e escrita, gerando profundas mudanças nas relações sociais (ESPINOSA-CURIEL et al., 2018). Para que a equipe esteja preparada para tais transformações, é importante definir e disseminar o novo modelo de comunicação previsto pelo modelo ágil, baseado em valores de colaboração e de integração da equipe (GANDOMANI; ZULZALIL; GHANI; SULTAN, 2013). 


\subsubsection{Documentação - RSL (UA 9)}

Como a documentação formal será reduzida, se a equipe do projeto não incorporar os valores ágeis de comunicação, poderá ocorrer um impacto de conhecimento no momento da transição ágil. Desta forma, a documentação do projeto deverá continuar existindo, mas de forma mais flexível do que no modelo tradicional, porém, com um conteúdo mínimo para que a equipe não perca nenhuma informação sobre o mesmo (ESPINOSA-CURIEL et al., 2018).

\subsubsection{Gestão do conhecimento - RSL (UA 10)}

Para que a equipe possa compartilhar conhecimento conforme os valores ágeis forem se estabelecendo, seus integrantes devem estar confiantes em relação ao processo e se sentir confortáveis para discutir issues e sugerir soluções. Para isso, pode-se adotar um esquema de trabalho baseado na transferência de conhecimento de mentores para os membros da equipe menos experientes (CONBOY et al., 2011). A gestão do conhecimento é muito importante no modelo ágil e deve fazer parte da cultura organizacional, criando um ambiente apropriado para o compartilhamento efetivo de informações (CHAN; THONG, 2009; GREGORY et al., 2016).

\subsubsection{Integração com outras áreas - RSL (UA 11)}

É importante que, ao adotar o modelo ágil, todas as equipes participantes o adotem (por exemplo, Produtos, Marketing e Infraestrutura) e não somente a equipe de Tecnologia. As chances de sucesso são bem menores quando as diversas equipes executam modelos distintos (por exemplo, quando a área de negócios utiliza o modelo tradicional e a área técnica, o ágil). A alta gestão deve comunicar a todas as equipes a importância da utilização do mesmo modelo por todos durante o projeto e o impacto caso não estejam em sintonia (COHN; FORD, 2003).

\subsubsection{Desafios de Pessoas na Análise da RSL}

Diversos autores da literatura acadêmica defendem que as maiores transformações organizacionais durante a transição ágil estão relacionadas aos aspectos humanos (GANDOMANI; ZULZALIL; GHANI; SULTAN, 2013; GANDOMANI; NAFCHI, 2016; 
NERUR; MAHAPATRA; MANGALARAJ, 2005; GANDOMANI et al., 2014; TOLFO; WAZLAWICK; FERREIRA; FORCELLINI, 2009), uma vez que a filosofia ágil está centrada nas pessoas, em seus papéis e em suas responsabilidades.

Neste subitem, foram detalhadas as transformações e as mudanças de mentalidade necessárias para que as equipes possam se adaptar ao novo modelo. A sumarização destes desafios está descrita no APÊNDICE C - DESAFIOS DE PESSOAS (UAs de 12 a 19).

\subsubsection{Estruturação da equipe - RSL (UA 12)}

Em relação à estruturação da equipe, no modelo ágil devem ser criadas equipes menores, em comparação com as grandes e disciplinadas dos modelos tradicionais. Projetos grandes devem ser divididos em várias frentes para facilitar a gestão (GANDOMANI; ZULZALIL; GHANI; SULTAN, et al., 2013; JOVANOVIĆ. NAFCHI, 2017). Se possível, equipes geograficamente distribuídas também devem ser alocadas fisicamente no mesmo espaço, ao menos no início do projeto, para melhorar a interação entre os seus membros e para aumentar as chances de sucesso do processo (COHN; FORD, 2003).

\subsubsection{Papéis e responsabilidades - RSL (UA 13)}

Os processos ágeis impactam os papéis e as responsabilidades dos membros da equipe, passando a exigir perfis multidisciplinares, auto motiváveis e com alta performance, o que consequentemente pode ser um grande impacto para a transição (COHN; FORD, 2003). A falta de conhecimento, por parte dos participantes, quanto às práticas ágeis da transição pode causar dificuldade ao serem definidas as responsabilidades da equipe (PIKKARAINEN; SALO; KUUSELA; ABRAHAMSSON, 2012).

Para que os atuais membros da equipe da organização possam se adaptar aos novos papéis, é imprescindível que recebam um treinamento formal no modelo ágil, seus processos e valores, além de treinamentos adicionais nos soft-skills, conforme exige este novo modelo (CHEN; RAVICHANDAR; PROCTOR, 2016; GANDOMANI; NAFCHI, 2016). A organização também deve estar ciente que, com a implantação do modelo ágil, os membros da equipe não devem mais ser alocados em múltiplos projetos simultaneamente (como ocorria nos modelos tradicionais), para que possam focar mais nos projetos dos quais estão participando e, assim, obter agilidade na sua implementação (PIKKARAINEN; SALO; KUUSELA; ABRAHAMSSON, 2012). 


\subsubsection{Tomada de decisão - RSL (UA 14)}

Os processos ágeis causam grande impacto na tomada de decisão dos membros da equipe, pois a eles é atribuída uma posição de protagonismo no projeto e não mais apenas uma posição participativa (CHEN; RAVICHANDAR; PROCTOR, 2016; GANDOMANI; NAFCHI, 2016). Desta forma, deve ser estimulada a criatividade e a contribuição de todos os membros da equipe e não apenas do Gerente de Projetos. A estimativa e o planejamento contínuos realizados pela equipe do projeto reforçarão o entendimento das necessidades do cliente e fortalecerão a capacidade da equipe (PIKKARAINEN; SALO; KUUSELA; ABRAHAMSSON, 2012).

Neste novo modelo, baseado em colaboração e comunicação, o Gerente de Projetos deve agir como um facilitador, participando da decisão final juntamente com toda a equipe, ao invés de assumir o perfil controlador como o que vinha desempenhando até então, nos modelos tradicionais (BOEHM; TURNER, 2005; CONBOY et al., 2011; NERUR; MAHAPATRA; MANGALARAJ, 2005). Muitos Gerentes de Projetos não conseguem abandonar o papel autoritário, mantendo seus valores tradicionais de liderança e, consequentemente, apresentando resistência à transição ágil. Quando isto ocorre, a equipe do projeto, não acostumada a tomar decisões, acaba mantendo uma postura passiva, não tomando para si a responsabilidade do projeto (GANDOMANI; ZULZALIL; GHANI;SULTAN, 2013). Nestes casos, a fim de manter equipes auto gerenciáveis e com liderança compartilhada, é necessário ajustar o poder e a influência de todos os membros da equipe (ESPINOSA-CURIEL et al., 2018).

\subsubsection{Colaboração - RSL (UA 15)}

O trabalho em equipe é ressaltado, sendo extremamente importante a colaboração de todos (CHAN; THONG, 2009; CHEN; RAVICHANDAR; PROCTOR, 2016), pois todos os membros são responsáveis pela conclusão do trabalho, o que significa que o ownership do projeto deve ser compartilhado. Os benefícios adquiridos também pertencem à equipe como um todo e não apenas a um único membro. Quando as equipes não conseguem mudar esta mentalidade, a transição torna-se muito mais difícil (GANDOMANI; NAFCHI, 2016). 


\subsubsection{Resistência à mudança - RSL (UA 16)}

Para que a transição ágil ocorra de forma mais efetiva, é importante ter o buy-in de toda a equipe que participará do novo processo (CONBOY et al., 2011). Como a maioria das mudanças é realizada no âmbito das pessoas e de seus respectivos comportamentos, atitudes e mentalidades, a equipe pode oferecer resistência e ter dificuldade de adaptação às práticas ágeis, no caso de essa implantação ser feita top-down. Em contrapartida, se não houver obrigatoriedade de adoção do novo processo, a transição pode também não funcionar, pois a equipe entende que ela não é mandatória e, por isso, não se sentirá motivada a realizar a transformação (CHAN; THONG, 2009).

Por este motivo, é importante que a gestão comunique a todos da organização quais são os objetivos e os benefícios da transição, para que as equipes tenham expectativas claras em relação ao processo e participem ativamente da transformação (CONBOY et al., 2011; GANDOMANI; NAFCHI, 2015 e 2016; JOVANOVIĆ et al., 2017; MAHANTI, 2006). Quando há falta de conhecimento em relação às práticas ágeis, há certa tendência de maior resistência por parte da equipe, ou ainda de uma expectativa diferente da realidade, o que pode causar frustração ou desmotivação. A resistência pode ocorrer em função da dificuldade de adaptação de mentalidade, comportamentos e atitudes frente ao novo processo, devido ao grande desafio que esta transição propõe (GANDOMANI; NAFCHI, 2016). Quanto mais forte for a cultura da organização, maior resistência à mudança ela oferecerá (JOVANOVIĆ et al., 2017).

\subsubsection{Cliente dedicado - RSL (UA 17)}

Outro desafio importante a ser enfrentado refere-se aos clientes, que representam um papel fundamental para o sucesso do projeto (CHAN; THONG, 2009). Enquanto nos modelos tradicionais, os clientes são considerados apenas stakeholders que fazem parte do projeto, nos modelos ágeis, eles são considerados membros da equipe (Product Owner e Business Owner) e responsáveis pelas decisões de escopo, de objetivos e de prioridades. Sendo assim, os clientes são fatores críticos para o sucesso da implantação dos modelos ágeis e devem se dedicar ao projeto com o mesmo papel de colaboração e de comunicação que os demais membros da equipe. A falta de proximidade e de engajamento por parte do cliente também pode acarretar consequências negativas para o projeto, tais como atraso na tomada de 
decisões, de definição e de validação de funcionalidades do produto e de priorização do backlog (JOVANOVIĆ et al., 2017).

As equipes de desenvolvimento devem solicitar frequentemente o feedback do cliente, de forma colaborativa, para poderem ajustar os processos utilizando o conceito de 'melhoria contínua' (CHEN; RAVICHANDAR; PROCTOR, 2016). Deste modo, devem ser definidos intervalos de tempo fixos para que, ao término de cada um deles, haja um entregável que possa ser validado pelo cliente. O cliente deve entender também que, no modelo ágil, ele não irá mais definir todos os requerimentos no início do projeto, como acontecia nos projetos baseados em modelos tradicionais. Portanto, para se adaptar ao modelo ágil, ele deverá mudar sua mentalidade, passando a trabalhar com pacotes parciais do produto e não mais com o produto final (PIKKARAINEN; SALO; KUUSELA; ABRAHAMSSON, 2012).

\subsubsection{Visibilidade da equipe - RSL (UA 18)}

A equipe pode se sentir intimidada devido à extrema visibilidade do trabalho da equipe; à necessidade de comunicação em relação ao seu progresso; e à qualidade e interação com a alta gestão da organização. Neste sentido, é necessário empoderar todos os membros da equipe para que tenham autoridade para tomar decisões em relação aos temas do projeto. Também é preciso treiná-los em skills de comunicação, para que se sintam mais seguros ao interagir com os níveis hierárquicos mais altos (CONBOY et al., 2011).

\subsubsection{Mudança de mindset - RSL (UA 19)}

A contratação de um coach é de extrema importância para apoiar a mudança de mindset da organização durante o processo de transição (CONBOY et al., 2011). O melhor modelo é a contratação de um coach externo à organização, que possa trazer novas perspectivas para o negócio e um feedback não enviesado, reduzindo a resistência das equipes quanto à adoção de novas práticas.

\subsubsection{Desafios da Gestão na Análise da RSL}

Os desafios de gestão estão relacionados principalmente com a adaptação da organização ao perfil de colaboração e com a comunicação do modelo ágil, ao contrário do 
perfil de comando e controle do modelo tradicional. A sumarização destes desafios está descrita no APÊNDICE D - DESAFIOS DE GESTÃO (UAs 20 e 21).

\subsubsection{Apoio da gestão - RSL (UA 20)}

Uma das premissas para a implantação do modelo ágil é o apoio da alta gestão e a aceitação dos princípios ágeis que este processo requer, para que não sejam barreiras (CAO et al., 2009; CHAN; THONG, 2009; CHEN; RAVICHANDAR; PROCTOR, 2016; JOVANOVIĆ et al., 2017; MAHANTI, 2006; GANDOMANI et al., 2014). A gestão da organização deve estar comprometida com a adoção do modelo ágil, dando todo o suporte necessário durante o processo de transição (PIKKARAINEN; SALO; KUUSELA; ABRAHAMSSON, 2012). Além disso, ela deve entender que a filosofia ágil não se refere apenas à implementação dos projetos de uma forma mais rápida, mas à execução de uma nova forma de trabalho. Para se tornar uma organização ágil, todos os funcionários, incluindo os da gestão da organização, devem aceitar os valores de colaboração, de comunicação e de gestão descentralizada que a filosofia propõe.

\subsubsection{Gestão descentralizada - RSL (UA 21)}

Como o modelo ágil propõe uma forma de gestão descentralizada, baseada na colaboração da equipe (ao contrário do modelo tradicional, baseado em comando e controle), pode haver um desconforto por parte da gestão da organização, que não irá querer abdicar do poder exercido no modelo tradicional (CHEN; RAVICHANDAR; PROCTOR, 2016; GANDOMANI; ZULZALIL; GHANI; SULTAN; NAFCHI, 2013; GREGORY et al., 2016; GANDOMANI; NAFCHI, 2016; NERUR; MAHAPATRA; MANGALARAJ, 2005). Este tipo de liderança representa uma mudança drástica no modelo de gestão da organização, em seus papéis e em suas responsabilidades. A expectativa da gestão em manter os valores tradicionais depois de ocorrer a transição ágil pode ser um fator de resistência para a adoção do novo processo (COCKBURN; HIGHSMITH, 2001).

Os gestores precisarão abrir mão do micro management e delegar a tomada de decisões para a equipe do projeto, servindo apenas como suporte e remoção de barreiras (CHEN; RAVICHANDAR; PROCTOR, 2016). Um exemplo é o controle quanto ao custo, ao prazo e ao status do projeto. Como no modelo ágil não há uma visão clara no início do projeto quanto ao prazo de conclusão e nem quanto ao investimento total necessário, a alta 
gestão não consegue rastrear e acompanhar o projeto, por meio de relatórios com os quais estava acostumada, para saber se está caminhando conforme o esperado (COHN; FORD, 2003).

É importante que a gestão da organização redefina suas expectativas de controle em relação ao projeto, anteriormente baseadas em projetos entregues com escopo, custo e prazo, conforme o planejado e com uma documentação formal. Entretanto, no modelo ágil, os projetos devem ser entregues com qualidade e valor para o negócio e com o mínimo de documentação possível (GREGORY et al., 2016). Estas diferenças não podem ser percebidas como falta de controle do projeto e sim como aderência aos valores do novo modelo. Apesar da perda de autoridade, muitos gestores consideram que as vantagens do modelo ágil superam os desafios enfrentados (GANDOMANI; ZULZALIL; GHANI; SULTAN; NAFCHI, 2013). A mudança de mentalidade é imprescindível para o sucesso da transição ágil.

\subsubsection{Desafios da Organização na Análise da RSL}

Os desafios da organização devem ser considerados sobretudo pela área de Recursos Humanos (RH), que deve participar ativamente do processo de transição ágil, alterando sua política de contratação, avaliação e estrutura hierárquica para se adaptar aos novos valores ágeis. A sumarização destes desafios está descrita no APÊNDICE E - DESAFIOS DA ORGANIZAÇÃO (UAs de 22 a 25).

\subsubsection{Estrutura hierárquica - RSL (UA 22)}

Como o modelo ágil prevê a tomada de decisão por todos os membros da equipe, os níveis hierárquicos devem sofrer modificações, sendo reduzidos a uma estrutura horizontalizada em toda a organização. A formação das equipes passa a ser não mais por áreas funcionais, e sim por equipes multidisciplinares, o que requer uma alteração na estrutura de cargos (CONBOY et al., 2011).

\subsubsection{Treinamento - RSL (UA 23)}

A falta de conhecimento quanto aos valores e aos processos ágeis pode representar alto risco para o processo de transição. Assim, antes de iniciar o processo de transição, a organização deve investir em treinamento, não apenas para os membros da equipe de 
desenvolvimento, mas também para as demais equipes de negócio, que participarão dos projetos, para lhes apresentar as características do novo processo e definir as expectativas (GANDOMANI; ZULZALIL; GHANI; SULTAN; NAFCHI, 2013; JOVANOVIĆ et al., 2017; MAHANTI, 2006). Este treinamento deve ser prioridade para a organização e dele devem participar todos os envolvidos, incluindo a alta gestão e os demais stakeholders do projeto, para que possam ter uma visão clara e entendimento das práticas a serem implementadas (PIKKARAINEN; SALO; KUUSELA et al., 2012).

As equipes devem ser capacitadas tanto em relação aos processos e aos valores do modelo ágil, como também em relação a outras habilidades, uma vez que o alto nível de especialização dos modelos tradicionais deverá ser substituído por perfis multidisciplinares (GREGORY et al., 2016; JOVANOVIĆ et al., 2017). Sendo assim, deve ser considerada a capacitação da equipe em habilidades sociais (soft skills), como comunicação, trabalho em equipe e técnicas de apresentação, além do entendimento do negócio, uma vez que haverá uma exposição maior da equipe frente aos diferentes níveis hierárquicos (CONBOY et al., 2011).

4.1.4.3 Contratação de profissionais - RSL (UA 24)

Devido ao perfil multidisciplinar que a filosofia ágil requer, os perfis específicos deixam de ser valorizados nas organizações que adotam o modelo ágil. A partir da transição, a área de Recursos Humanos deve direcionar seus esforços para a contratação de profissionais qualificados tanto nas habilidades técnicas quanto na de negócios, além das habilidades sociais exigidas pelo modelo ágil, como a comunicação e a colaboração (CONBOY et al., 2011; MAHANTI, 2006).

\subsubsection{Avaliação de performance - RSL (UA 25)}

A implementação de modelos ágeis, impacta também na avaliação de performance, passando de uma avaliação individual, como ocorria nos modelos tradicionais, para uma avaliação em grupo, considerando critérios de colaboração, comunicação, interação e trabalho em equipe. As métricas de avaliação corporativa também devem ser adaptadas para considerar indicadores de performance em grupo, além dos critérios individuais existentes (CHEN; RAVICHANDAR; PROCTOR, 2016; CONBOY et al., 2011; GANDOMANI; NAFCHI, 2016). Sendo assim, a área de Recursos Humanos deve pensar em uma gestão de carreira que 
apresente vantagens para os funcionários no futuro e os motive a aceitar a transição, tais como recompensas, maior flexibilidade para mudança de carreira e oportunidades de trabalho dentro da própria organização (CHAN; THONG, 2009).

\subsection{ANÁLISE DOS RESULTADOS DA COLETA DE DADOS PRIMÁRIOS}

Neste subcapítulo serão analisados os dados primários coletados nas entrevistas, referentes a cada uma das Unidades de Análise, comparando a recomendação da literatura acadêmica com a aplicação da prática pela organização em questão. Em função das informações coletadas por meio das respostas dos entrevistados, foram identificadas Subunidades.

Para cada uma das questões das entrevistas foi elaborado um quadro, contendo cinco colunas. Na primeira coluna à esquerda consta a identificação do entrevistado (E1, E2, E3 e assim sucessivamente até E10), embora nem sempre todos eles estarão relacionados numa mesma questão. Nas colunas "Mensagem Principal" e "Mensagem Associada" constam os principais comentários dos entrevistados em relação a cada uma das questões. Nas colunas "Interpretação da mensagem principal" e "Interpretação da mensagem associada" constam as interpretações da própria autora em relação às respostas dos entrevistados. Na parte inferior de cada um dos quadros, foi inserida uma célula, identificada com as iniciais do nome da autora - MP, na qual consta sua análise geral em relação à Unidade ou à Subunidade de Análise, tendo como base tanto as respostas dadas pelos entrevistados para a questão específica, como também sua associação com as demais UAs.

\subsubsection{Desafios de Processos na Análise da Coleta de Dados Primários}

\subsubsection{Transição Big Bang - coleta de dados primários (UA 1)}

A recomendação é que a transição do modelo tradicional para o ágil seja realizada de forma gradual e iterativa, com a implantação de um projeto piloto. Somente depois da adequação da equipe às práticas ágeis, é que se recomenda a ampliação para os demais projetos, de acordo com o conceito de melhoria contínua. Neste cenário, durante a transição, pode ocorrer a aplicação de um modelo híbrido. 
a) Transição gradual

Todos os entrevistados mencionaram que a transição ocorreu de forma gradual na organização, embora tenha ocorrido variação na implantação das seguintes formas:

- Por unidade de negócio: três dos entrevistados (E1, E4 e E5) informaram que a transição iniciou pela área de negócios, expandindo progressivamente para as demais unidades;

- Por cadeia de valor: dois dos entrevistados (E2 e E9) informaram que houve um período de implantação de squads por cadeia de valor nas organizações, iniciando por uma ou mais squads e aumentando progressivamente na medida em que foi ocorrendo a adaptação das equipes. Porém, ambos informaram que a transição iniciou com um grande número de squads, tornando-se inviável. Foi, então, necessário reduzir a quantidade inicial, acrescentando-as à medida que as equipes foram se consolidando com o novo modelo;

- Por produto: dois dos entrevistados (E6 e E10) informaram que foram escolhidos alguns dos projetos estratégicos da companhia, geralmente envolvendo produtos digitais ou novos produtos de inovação, para serem desenvolvidos no modelo ágil. Os demais produtos ainda permaneceram no modelo tradicional por certo período até migrarem para o modelo ágil;

- Por práticas ágeis: três dos entrevistados (E3, E7 e E8) mencionaram que as novas práticas foram sendo introduzidas gradativamente, geralmente iniciando pelas cerimônias da sprint (Daily, Sprint Planning, Sprint Review e Sprint Retrospective), porém, com o tombamento total dos projetos para o novo modelo. Em alguns casos, esta estratégia resultou em um modelo híbrido intermediário (Quadro 3). 
Quadro 3 - Análise da coleta de dados: Transição Big Bang - Transição gradual

\begin{tabular}{|c|c|c|c|c|}
\hline \multirow{4}{*}{ 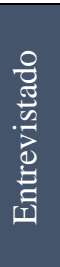 } & Unidade de Análise 1 & \multicolumn{3}{|l|}{ Transição Big Bang } \\
\hline & Questão & \multicolumn{3}{|c|}{$\begin{array}{l}\text { Q3: A implementação foi realizada de forma gradual, contínua, iterativa ou Big } \\
\text { Bang? Foi utilizado um projeto piloto para a transição? }\end{array}$} \\
\hline & Subunidade & \multicolumn{3}{|l|}{ Transição gradual } \\
\hline & Mensagem principal & $\begin{array}{c}\text { Interpretação da mensagem } \\
\text { principal }\end{array}$ & Mensagem associada & $\begin{array}{c}\text { Interpretação da } \\
\text { mensagem associada }\end{array}$ \\
\hline E1 & $\begin{array}{l}\text { "Foi gradual... Hoje o } \\
\text { modelo está na fase de } \\
\text { experimentação em } \\
\text { algumas unidades de } \\
\text { negócios. Nas áreas } \\
\text { escolhidas como piloto, } \\
\text { já aplicamos as } \\
\text { cerimônias e } \\
\text { ferramentas". }\end{array}$ & $\begin{array}{l}\text { A transição foi realizada por } \\
\text { unidade de negócio. }\end{array}$ & $\begin{array}{l}\text { "Teve uma fase inicial } \\
\text { para divulgar a cultura } \\
\text { ágil, com vídeos e } \\
\text { treinamentos. Depois } \\
\text { teve a contratação de } \\
\text { uma consultoria } \\
\text { externa para apoiar na } \\
\text { transformação". }\end{array}$ & $\begin{array}{l}\text { A transição só foi } \\
\text { efetivada depois da } \\
\text { contratação da } \\
\text { consultoria. } \mathrm{Na} \\
\text { primeira fase, era } \\
\text { apenas para } \\
\text { disseminar a ideia do } \\
\text { modelo ágil na } \\
\text { organização. }\end{array}$ \\
\hline E2 & $\begin{array}{l}\text { "Foi iterativa e } \\
\text { gradual... A gente } \\
\text { rampou inicialmente } \\
\text { alguns squads que a } \\
\text { gente entendia que } \\
\text { tinham alguns } \\
\text { conceitos ágeis já } \\
\text { rolando". }\end{array}$ & $\begin{array}{l}\text { A transição ágil iniciou pelas } \\
\text { squads com maior aderência ao } \\
\text { ágil. }\end{array}$ & $\begin{array}{l}\text { "Nós tínhamos planos } \\
\text { muito, mas muito } \\
\text { assim da NASA com } \\
\text { relação a rampar } 55 \\
\text { milhões de squads... E } \\
\text { daí o que a gente } \\
\text { percebeu, que era um } \\
\text { sonho utópico". }\end{array}$ & $\begin{array}{l}\text { Deveria ser mais } \\
\text { conservador. Iniciar } \\
\text { com poucas squads; } \\
\text { sanar os problemas e } \\
\text { depois ir } \\
\text { incrementando as } \\
\text { demais squads } \\
\text { (melhoria contínua). }\end{array}$ \\
\hline E3 & $\begin{array}{l}\text { "Foi gradual. A cada } \\
\text { release a gente ia se } \\
\text { adequando à } \\
\text { metodologia". }\end{array}$ & $\begin{array}{l}\text { As práticas ágeis foram sendo } \\
\text { introduzidas gradativamente } \\
\text { nas equipes. }\end{array}$ & $\begin{array}{l}\text { "Hoje a metodologia } \\
\text { de projetos é } \\
\text { totalmente diferente } \\
\text { da que a gente } \\
\text { começou". }\end{array}$ & $\begin{array}{l}\text { Esta estratégia de } \\
\text { transição pode gerar } \\
\text { um modelo híbrido } \\
\text { intermediário. }\end{array}$ \\
\hline E4 & $\begin{array}{l}\text { "Começou por uma } \\
\text { unidade de negócio, } \\
\text { uma área que atendia } \\
\text { os clientes". }\end{array}$ & $\begin{array}{l}\text { A transição foi realizada por } \\
\text { unidade de negócio. }\end{array}$ & $\begin{array}{l}\text { "Aí, depois, se a área } \\
\text { ainda fosse fazer } \\
\text { algum projeto } \\
\text { tradicional ia depender } \\
\text { do cliente... a menos } \\
\text { que o cliente falasse } \\
\text { especificamente que } \\
\text { queria aquilo no } \\
\text { modelo tradicional. } \\
\text { Mas aí ficaria mais } \\
\text { tradicional da porta } \\
\text { para fora, né? Porque } \\
\text { dentro o time estava } \\
\text { fazendo a daily, retro e } \\
\text { tudo o mais". }\end{array}$ & $\begin{array}{l}\text { Para as unidades de } \\
\text { negócio já migradas, } \\
\text { mesmo que o cliente } \\
\text { não concordasse com } \\
\text { o novo modelo, as } \\
\text { práticas ágeis foram } \\
\text { mantidas dentro da } \\
\text { organização. }\end{array}$ \\
\hline E5 & $\begin{array}{l}\text { "A gente embarcou } \\
\text { duas esteiras no ano } \\
\text { passado... Com as duas } \\
\text { novas esteiras que } \\
\text { foram criadas, essas } \\
\text { duas novas } \\
\text { automaticamente já } \\
\text { estão no ágil". }\end{array}$ & $\begin{array}{l}\text { A transição foi realizada por } \\
\text { unidade de negócio. }\end{array}$ & $\begin{array}{l}\text { "No primeiro semestre } \\
\text { a gente criou um } \\
\text { grupo de trabalho para } \\
\text { falar da } \\
\text { transformação... No } \\
\text { segundo semestre a } \\
\text { gente começou a criar } \\
\text { uns pilotos internos... } \\
\text { E a gente definiu a } \\
\text { proposta de contratar } \\
\text { uma consultoria para } \\
\text { fazer a } \\
\text { transformação..." }\end{array}$ & $\begin{array}{l}\text { Houve uma iniciativa } \\
\text { ágil na empresa, } \\
\text { porém de forma } \\
\text { tímida. A } \\
\text { implantação efetiva } \\
\text { nas unidades ocorreu } \\
\text { apenas depois da } \\
\text { contratação da } \\
\text { consultoria. }\end{array}$ \\
\hline
\end{tabular}




\begin{tabular}{|c|c|c|c|c|}
\hline \multirow{4}{*}{ 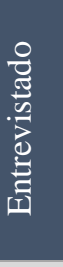 } & Unidade de Análise 1 & \multicolumn{3}{|l|}{ Transição Big Bang (Continuação) } \\
\hline & Questão & \multicolumn{3}{|c|}{$\begin{array}{l}\text { Q3: A implementação foi realizada de forma gradual, contínua, iterativa ou Big } \\
\text { Bang? Foi utilizado um projeto piloto para a transição? }\end{array}$} \\
\hline & Subunidade & \multicolumn{3}{|l|}{ Transição gradual } \\
\hline & Mensagem principal & $\begin{array}{c}\text { Interpretação da mensagem } \\
\text { principal }\end{array}$ & Mensagem associada & $\begin{array}{c}\text { Interpretação da } \\
\text { mensagem associada }\end{array}$ \\
\hline E6 & $\begin{array}{l}\text { "O PMO já estava com } \\
\text { alguns projetos em ágil, } \\
\text { já tinha dois times } \\
\text { ágeis rodando em } \\
\text { alguns novos } \\
\text { produtos". }\end{array}$ & $\begin{array}{l}\text { A implementação do modelo } \\
\text { ágil foi iniciada para os } \\
\text { projetos de novos produtos. }\end{array}$ & $\begin{array}{l}\text { "A palavra final da } \\
\text { Consultoria fortaleceu } \\
\text { e fez com que a } \\
\text { Empresa passasse a } \\
\text { investir de fato nisso". }\end{array}$ & $\begin{array}{l}\text { A contratação da } \\
\text { consultoria fortaleceu } \\
\text { a implantação do } \\
\text { modelo ágil na } \\
\text { organização. }\end{array}$ \\
\hline E7 & $\begin{array}{l}\text { "Eles começaram } \\
\text { introduzindo sprint... } \\
\text { Depois que cada } \\
\text { unidade já sabia rodar o } \\
\text { scrum, a gente foi falar } \\
\text { sobre release... Depois } \\
\text { que estava todo mundo } \\
\text { firme, aí eles } \\
\text { começaram a trazer o } \\
\text { framework". }\end{array}$ & $\begin{array}{l}\text { As práticas ágeis foram sendo } \\
\text { introduzidas gradativamente } \\
\text { nas equipes, chegando a atingir } \\
\text { o nível de ágil escalado. }\end{array}$ & $\begin{array}{l}\text { "Eles começaram em } \\
\text { junho e falaram: 'até } \\
\text { dezembro todo mundo } \\
\text { na agilidade... é para } \\
\text { mandar embora quem } \\
\text { é para mandar e } \\
\text { contratar quem é pra } \\
\text { contratar'. E além da } \\
\text { agilidade, eles } \\
\text { extinguiram os } \\
\text { terceiros". }\end{array}$ & $\begin{array}{l}\text { A diretoria da } \\
\text { organização definiu } \\
\text { um prazo curto para a } \\
\text { conclusão da } \\
\text { transição, com alto } \\
\text { impacto nas pessoas. }\end{array}$ \\
\hline E8 & $\begin{array}{l}\text { "O nosso Delivery } \\
\text { Manager foi montando } \\
\text { as equipes... E a gente } \\
\text { colocou a cadência nas } \\
\text { cerimônias... E aí no } \\
\text { final do ano o nosso } \\
\text { Agile Coach trabalhou } \\
\text { e a gente ... colocou } \\
\text { um time voltado para } \\
\text { produto". }\end{array}$ & $\begin{array}{l}\text { As práticas foram sendo } \\
\text { introduzidas paulatinamente, } \\
\text { por iniciativa do gestor e não } \\
\text { da organização. }\end{array}$ & $\begin{array}{l}\text { "Vieram as pessoas } \\
\text { para fazer os papéis... } \\
\text { mas o Delivery } \\
\text { Manager não } \\
\text { acompanhava, porque } \\
\text { ele mesmo falou: } \\
\text { 'gente, eu era sozinho } \\
\text { para fazer tudo, então } \\
\text { não tinha como'". }\end{array}$ & $\begin{array}{l}\text { Houve uma } \\
\text { dificuldade muito } \\
\text { grande para } \\
\text { implementar o } \\
\text { modelo ágil sem o } \\
\text { apoio da organização. }\end{array}$ \\
\hline E9 & $\begin{array}{l}\text { "A gente chegou a } \\
\text { montar } 8 \text { squads. Só } \\
\text { que tinha tanto } \\
\text { problema, tanta } \\
\text { instabilidade... que } \\
\text { quando a Consultoria } \\
\text { entrou, ela falou: 'nós } \\
\text { vamos focar e trabalhar } \\
\text { em } 4 \text { squads... Quando } \\
\text { a gente estiver bem } \\
\text { consolidado, a gente } \\
\text { expande". }\end{array}$ & $\begin{array}{l}\text { A transição ágil foi realizada } \\
\text { por squads, porém houve a } \\
\text { necessidade de reduzir a } \\
\text { quantidade inicial para sanar os } \\
\text { problemas antes de escalar para } \\
\text { as demais squads. }\end{array}$ & $\begin{array}{l}\text { "A gente desmontou } \\
\text { as } 8 \text { [squads], focou só } \\
\text { em } 4 \text {. Essas } 4 \text { a gente } \\
\text { veio melhorando e } \\
\text { crescendo... Mas fez } \\
\text { um monte de coisas e } \\
\text { em dezembro estava } \\
\text { bem consolidado... e } \\
\text { hoje a gente tem } 16 \\
\text { squads". }\end{array}$ & $\begin{array}{l}\text { A transição deve ser } \\
\text { conservadora, } \\
\text { utilizando o conceito } \\
\text { de melhoria contínua. } \\
\text { Assim que eles } \\
\text { reduziram a } \\
\text { quantidade e focaram } \\
\text { nos problemas, foi } \\
\text { possível escalar o } \\
\text { modelo. }\end{array}$ \\
\hline E10 & $\begin{array}{l}\text { "Eu cuido de um } \\
\text { produto... O Escritório } \\
\text { de Projetos pediu para } \\
\text { que eu implementasse o } \\
\text { modelo ágil". }\end{array}$ & $\begin{array}{l}\text { A implementação do modelo } \\
\text { ágil foi iniciada para os } \\
\text { projetos de novos produtos. }\end{array}$ & $\begin{array}{l}\text { "Só que as lideranças } \\
\text { não acreditam nesse } \\
\text { modelo... Então, você } \\
\text { não pode, por } \\
\text { exemplo, chamar de } \\
\text { Planning, chamar de } \\
\text { Daily, não pode } \\
\text { chamar de Review. } \\
\text { Você tem que chamar } \\
\text { de reunião de } \\
\text { planejamento". }\end{array}$ & $\begin{array}{l}\text { A decisão de } \\
\text { implementar novos } \\
\text { produtos utilizando o } \\
\text { modelo ágil ocorreu } \\
\text { de forma prematura, } \\
\text { sem que a empresa } \\
\text { estivesse preparada } \\
\text { para a transformação. }\end{array}$ \\
\hline
\end{tabular}




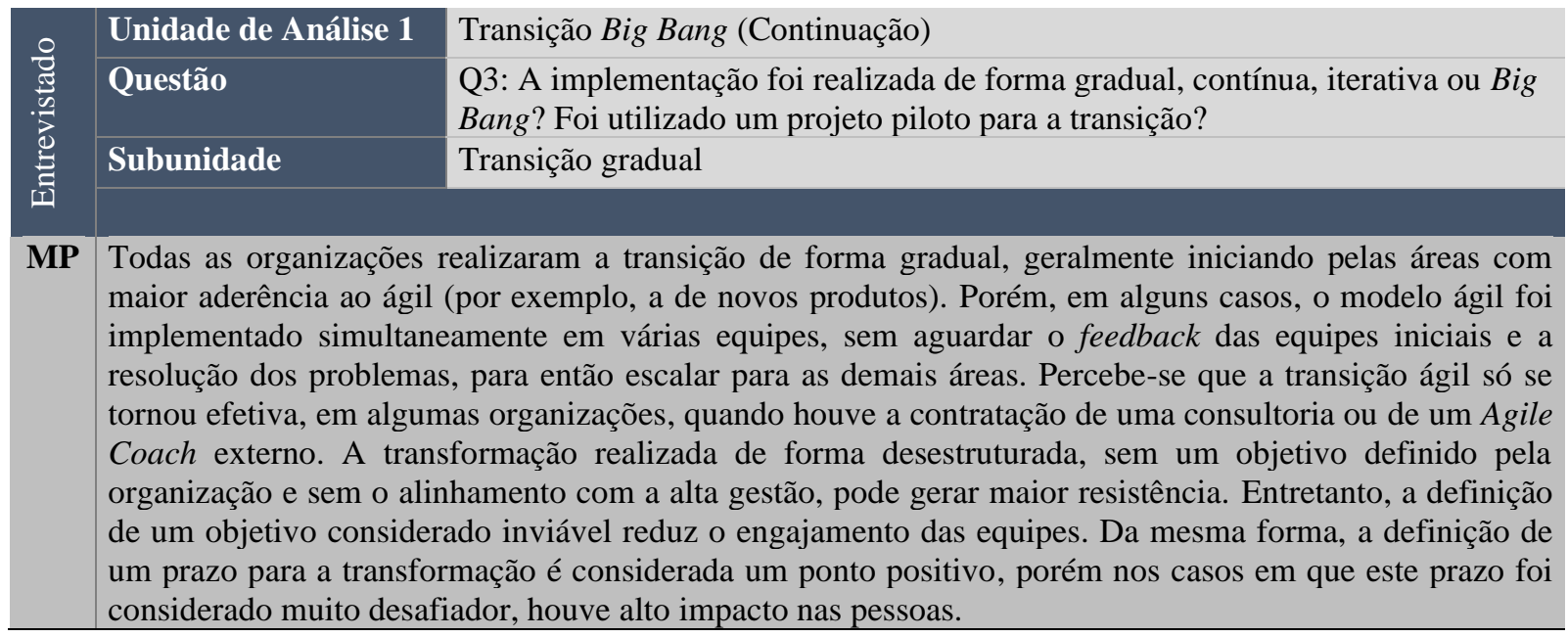

Fonte: Quadro elaborado pela autora, com base nas entrevistas.

b) Modelo híbrido

A transição gradual, mencionada acima, pode resultar na aplicação temporária de um modelo híbrido de gestão de projetos, enquanto as práticas ágeis ainda não estiverem absorvidas pelas equipes. Cinco dos entrevistados (E2, E3, E7, E8 e E10) mencionaram a existência deste modelo intermediário (muitas vezes denominado 'cascágil'), que contempla a aplicação de algumas práticas ágeis pelas equipes em transição (por exemplo, pela equipe de Tecnologia), porém mantendo a estrutura do projeto no modelo tradicional (Quadro 4).

Quadro 4 - Análise da coleta de dados: Transição Big Bang - Modelo híbrido

\begin{tabular}{|c|c|c|c|c|}
\hline \multirow{4}{*}{ 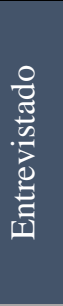 } & Unidade de Análise 1 & \multicolumn{3}{|l|}{ Transição Big Bang } \\
\hline & Questão & \multicolumn{3}{|c|}{$\begin{array}{l}\text { Q6: Houve algum período em que os modelos híbridos, com práticas e projetos } \\
\text { tradicionais e ágeis, foram executados simultaneamente? }\end{array}$} \\
\hline & Subunidade & \multicolumn{3}{|l|}{ Modelo híbrido } \\
\hline & Mensagem principal & $\begin{array}{c}\text { Interpretação da } \\
\text { mensagem } \\
\text { principal }\end{array}$ & $\begin{array}{l}\text { Mensagem } \\
\text { associada }\end{array}$ & $\begin{array}{l}\text { Interpretação da mensagem } \\
\text { associada }\end{array}$ \\
\hline E2 & $\begin{array}{l}\text { "O que é o cascágil? ... } \\
\text { Eu faço todo o meu } \\
\text { planejamento em } \\
\text { sprints, mas eu só } \\
\text { entrego numa data lá na } \\
\text { frente. Então eu faseio. } \\
\text { Eu coloco lá as histórias } \\
\text { priorizadas nas sprints. } \\
\text { Eu testo e guardo". }\end{array}$ & $\begin{array}{l}\text { Foi priorizada a } \\
\text { aplicação das } \\
\text { práticas ágeis nas } \\
\text { equipes, mantendo } \\
\text { a estrutura do } \\
\text { projeto tradicional. }\end{array}$ & $\begin{array}{l}\text { "Se a gente for } \\
\text { colocar numa linha } \\
\text { do tempo, a gente } \\
\text { começou pelas } \\
\text { squads para depois } \\
\text { disseminar para os } \\
\text { projetos". }\end{array}$ & $\begin{array}{l}\text { É importante inserir a cultura de } \\
\text { realização dos ritos ágeis nas } \\
\text { equipes desde o início, mesmo que } \\
\text { os resultados da agilidade ainda não } \\
\text { sejam obtidos. }\end{array}$ \\
\hline
\end{tabular}




\begin{tabular}{|c|c|c|c|c|}
\hline \multirow{4}{*}{ 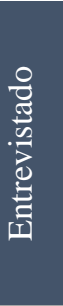 } & Unidade de Análise 1 & \multicolumn{3}{|c|}{ Transição Big Bang (Continuação) } \\
\hline & Questão & \multicolumn{3}{|c|}{$\begin{array}{l}\text { Q6: Houve algum período em que os modelos híbridos, com práticas e projetos } \\
\text { tradicionais e ágeis, foram executados simultaneamente? }\end{array}$} \\
\hline & Subunidade & \multicolumn{3}{|l|}{ Modelo híbrido } \\
\hline & Mensagem principal & $\begin{array}{l}\text { Interpretação da } \\
\text { mensagem } \\
\text { principal }\end{array}$ & $\begin{array}{l}\text { Mensagem } \\
\text { associada }\end{array}$ & $\begin{array}{c}\text { Interpretação da mensagem } \\
\text { associada }\end{array}$ \\
\hline E3 & $\begin{array}{l}\text { "Antes a gente falava } \\
\text { que era um 'cascágil'. } \\
\text { Eram duas semanas de } \\
\text { desenvolvimento e duas } \\
\text { semanas de } \\
\text { homologação... Agora } \\
\text { não. A gente trabalha } \\
\text { com duas semanas e as } \\
\text { coisas vão acontecendo } \\
\text { em paralelo para ganhar } \\
\text { agilidade". }\end{array}$ & $\begin{array}{l}\text { Foi priorizada a } \\
\text { aplicação das } \\
\text { práticas ágeis nas } \\
\text { equipes, mantendo } \\
\text { a estrutura do } \\
\text { projeto tradicional. }\end{array}$ & $\begin{array}{l}\text { "Demorava duas } \\
\text { semanas } \\
\text { desenvolvendo, e } \\
\text { quando chegava na } \\
\text { homologação } \\
\text { capotava... Agora } \\
\text { não. Você vai } \\
\text { desenvolvendo e vai } \\
\text { entregando... Nisso a } \\
\text { gente evoluiu muito. } \\
\text { Mas os ritos em si, } \\
\text { eles são bem } \\
\text { parecidos com os que } \\
\text { a gente tinha desde o } \\
\text { começo". }\end{array}$ & $\begin{array}{l}\text { É importante inserir a cultura de } \\
\text { realização dos ritos ágeis nas } \\
\text { equipes desde o início, mesmo que } \\
\text { os resultados da agilidade ainda não } \\
\text { sejam obtidos. }\end{array}$ \\
\hline E7 & $\begin{array}{l}\text { "Eu tive que } \\
\text { transformar as entregas } \\
\text { pendentes do [modelo] } \\
\text { cascata. Eu coloquei } \\
\text { numa linha de tempo } \\
\text { dentro de sprint. Ficou } \\
\text { um 'cascágil' ali naquela } \\
\text { fase de transição, até } \\
\text { terminar aquelas } \\
\text { entregas que já estavam } \\
\text { comprometidas em } \\
\text { projetos". }\end{array}$ & $\begin{array}{l}\text { As entregas foram } \\
\text { priorizadas de } \\
\text { acordo com o } \\
\text { modelo ágil, porém } \\
\text { houve necessidade } \\
\text { de analisar as que } \\
\text { já estavam } \\
\text { comprometidas. }\end{array}$ & $\begin{array}{l}\text { "Eu peguei, fiz a lista } \\
\text { de tudo, passei para o } \\
\text { PO, e falei: 'olha, isso } \\
\text { aqui eram todas } \\
\text { coisas } \\
\text { comprometidas, } \\
\text { como é que a gente } \\
\text { vai fazer agora?' Eu } \\
\text { envolvi o PO e o time } \\
\text { junto, porque o time } \\
\text { tem que falar se eles } \\
\text { vão entregar ou não". }\end{array}$ & $\begin{array}{l}\text { É importante } \\
\text { envolver o PO e } \\
\text { a equipe de } \\
\text { desenvolvimento } \\
\text { na decisão de } \\
\text { priorização, para } \\
\text { que eles se } \\
\text { sintam parte da } \\
\text { decisão. }\end{array}$ \\
\hline E8 & $\begin{array}{l}\text { "Não tinha retrospectiva } \\
\text { e refinamento. Eles } \\
\text { faziam uma planning e } \\
\text { um tipo review... o time } \\
\text { falava o que fazia, mas } \\
\text { não necessariamente ele } \\
\text { mostrava". }\end{array}$ & $\begin{array}{l}\text { A não } \\
\text { obrigatoriedade da } \\
\text { realização das } \\
\text { cerimônias é um } \\
\text { risco para a } \\
\text { transição, pois } \\
\text { impacta no } \\
\text { engajamento da } \\
\text { equipe. }\end{array}$ & $\begin{array}{l}\text { "Na minha opinião, } \\
\text { só ter as cerimônias } \\
\text { não é transformar } \\
\text { uma empresa em ágil, } \\
\text { né. Eu acho que tem } \\
\text { muito mais coisa } \\
\text { ainda por vir". }\end{array}$ & $\begin{array}{l}\text { Neste caso, a empresa não evoluiu } \\
\text { com a adoção da cultura ágil depois } \\
\text { da aplicação das cerimônias. }\end{array}$ \\
\hline E10 & $\begin{array}{l}\text { "Eles começaram muito } \\
\text { ágeis, e agora estão } \\
\text { mais híbridos... Porque } \\
\text { uma PO não concorda } \\
\text { com o ágil... Então ela } \\
\text { acha que tem que ter } \\
\text { uma reunião de status } \\
\text { report...". }\end{array}$ & $\begin{array}{l}\text { A não } \\
\text { obrigatoriedade da } \\
\text { realização das } \\
\text { cerimônias é um } \\
\text { risco para a } \\
\text { transição, pois } \\
\text { impacta no } \\
\text { engajamento da } \\
\text { equipe. }\end{array}$ & & \\
\hline
\end{tabular}

MP Como a adoção das novas práticas gera resistência nas equipes, o modelo híbrido é importante para que elas incorporem gradativamente a cultura ágil. Porém, as organizações que não evoluem neste modelo, incrementando as práticas e as equipes que participam do processo, não conseguem atingir todos os benefícios da agilidade. Além disso, quando a organização não considera como mandatória a adoção das práticas ágeis, há um alto risco na adoção do novo modelo, podendo resultar no seu abandono pelas equipes.

Fonte: Quadro elaborado pela autora, com base nas entrevistas. 
4.2.1.2 Preparação para a transição ágil - coleta de dados primários (UA 2)

A literatura recomenda que as organizações tenham um motivador claro para a realização da transição, que justifique a adoção do modelo ágil. Além disso, deve haver um assessment prévio na organização, para avaliar se ela está preparada para a transição e se o modelo ágil se adapta à cultura organizacional.

a) Motivadores para a transformação

Questionados quanto aos motivadores para a transição ágil pela organização, três dos entrevistados (E2, E3 e E9) informaram que o principal deles foi a nova concorrência de mercado que a organização passou a sofrer, gerando uma pressão pelo desenvolvimento de produtos e serviços inovadores em um menor prazo. Outros três entrevistados (E5, E7 e E10) citaram a necessidade de a organização acompanhar o mercado, considerando um "modismo" a ser seguido. Apenas dois dos entrevistados (E1 e E6) mencionaram o reposicionamento estratégico da organização como o principal motivador da transformação ágil. Dois dos entrevistados (E4 e E8) relataram também a iniciativa de alguns líderes para a implementação do modelo ágil em sua equipe. O entrevistado $\mathrm{E} 4$ relatou que a transição evoluiu posteriormente para uma implementação global da organização, porém, o entrevistado E8 afirmou que não houve o apoio da organização para que o modelo ágil fosse adotado pelas demais áreas (Quadro 5).

Quadro 5 - Análise da coleta de dados: Preparação para a transição ágil - Motivador para a transformação

\begin{tabular}{|c|c|c|c|c|}
\hline & Unidade de Análise 2 & \multicolumn{3}{|c|}{ Preparação para a transição ágil } \\
\hline 曽 & Questão & \multicolumn{3}{|c|}{$\begin{array}{l}\text { Q1: Qual foi o principal motivador para a empresa decidir pelo projeto de } \\
\text { transformação ágil? }\end{array}$} \\
\hline$\stackrel{3}{\Xi}$ & Subunidade & \multicolumn{3}{|c|}{ Motivador para a transformação } \\
\hline 甜 & Mensagem principal & $\begin{array}{l}\text { Interpretação da } \\
\text { mensagem principal }\end{array}$ & Mensagem associada & $\begin{array}{c}\text { Interpretação da } \\
\text { mensagem associada }\end{array}$ \\
\hline E1 & $\begin{array}{l}\text { "Foi uma } \\
\text { movimentação } \\
\text { estratégica porque a alta } \\
\text { administração entendeu } \\
\text { que esta transição traria } \\
\text { mais valor para a } \\
\text { empresa e também mais } \\
\text { foco no cliente interno". }\end{array}$ & $\begin{array}{l}\text { Não houve na } \\
\text { organização uma } \\
\text { pressão para a entrega } \\
\text { mais rápida ou com } \\
\text { menor custo, apenas } \\
\text { para geração de valor } \\
\text { para o cliente interno. }\end{array}$ & $\begin{array}{l}\text { "Agora, os usuários } \\
\text { estão junto com as } \\
\text { áreas técnicas... então } \\
\text { isso traz mais valor } \\
\text { para a entrega e o } \\
\text { projeto ocorre de forma } \\
\text { mais rápida". }\end{array}$ & $\begin{array}{l}\text { A entrega mais rápida foi } \\
\text { consequência da } \\
\text { transformação ágil na } \\
\text { organização, porém não o } \\
\text { objetivo. }\end{array}$ \\
\hline
\end{tabular}




\begin{tabular}{|c|c|c|c|c|}
\hline \multirow{4}{*}{ 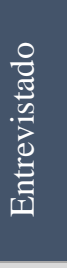 } & Unidade de Análise 2 & \multicolumn{3}{|c|}{ Preparação para a transição ágil (Continuação) } \\
\hline & Questão & \multicolumn{3}{|c|}{$\begin{array}{l}\text { Q1: Qual foi o principal motivador para a empresa decidir pelo projeto de } \\
\text { transformação ágil? }\end{array}$} \\
\hline & Subunidade & \multicolumn{3}{|c|}{ Motivador para a transformação } \\
\hline & Mensagem principal & $\begin{array}{l}\text { Interpretação da } \\
\text { mensagem principal }\end{array}$ & Mensagem associada & $\begin{array}{l}\text { Interpretação da } \\
\text { mensagem associada }\end{array}$ \\
\hline E2 & $\begin{array}{l}\text { "Até } 4 \text { anos atrás nós } \\
\text { reinávamos unicamente } \\
\text { nesse mercado e com a } \\
\text { pressão de entrega cada } \\
\text { vez maior... A gente viu } \\
\text { o que o processo } \\
\text { anterior que nós } \\
\text { tínhamos de } \\
\text { desenvolvimento de } \\
\text { software e de gestão de } \\
\text { projetos não abraçava } \\
\text { esse time-to-market que } \\
\text { a gente tem 'hoje'". }\end{array}$ & $\begin{array}{l}\text { O principal motivador } \\
\text { da organização foi a } \\
\text { nova concorrência do } \\
\text { mercado que, por ser } \\
\text { mais ágil, possui um } \\
\text { melhor time-to-market. }\end{array}$ & $\begin{array}{l}\text { "O concorrente lança } \\
\text { para depois a gente } \\
\text { correr atrás. Então, a } \\
\text { tentativa de } \\
\text { digitalizar... os nossos } \\
\text { processos é para tentar } \\
\text { ser a vanguarda e não } \\
\text { reativo". }\end{array}$ & $\begin{array}{l}\text { A organização estava } \\
\text { acostumada a ser } \\
\text { protagonista no mercado de } \\
\text { atuação, porém perdeu este } \\
\text { espaço para a concorrência } \\
\text { devido aos seus processos } \\
\text { burocráticos. }\end{array}$ \\
\hline $\mathbf{E 3}$ & $\begin{array}{l}\text { "O principal motivador, } \\
\text { para mim, foi ganhar } \\
\text { tempo de mercado. A } \\
\text { gente demorava muito } \\
\text { para lançar produto... } \\
\text { então a gente precisou } \\
\text { se movimentar e ser } \\
\text { mais ágil". }\end{array}$ & $\begin{array}{l}\text { A organização precisou } \\
\text { se tornar mais ágil para } \\
\text { desenvolver novos } \\
\text { produtos mais } \\
\text { rapidamente. }\end{array}$ & $\begin{array}{l}\text { "Agora é um } \\
\text { adquirente a cada } \\
\text { esquina. E como elas } \\
\text { começam } \\
\text { pequenininhas, elas são } \\
\text { naturalmente mais } \\
\text { ágeis". }\end{array}$ & $\begin{array}{l}\text { O principal motivador da } \\
\text { organização foi a nova } \\
\text { concorrência do mercado } \\
\text { que, por ser mais ágil, } \\
\text { possui um melhor time-to- } \\
\text { market. }\end{array}$ \\
\hline $\mathbf{E 4}$ & $\begin{array}{l}\text { "A Vice-Presidente da } \\
\text { Empresa começou a } \\
\text { fazer alguns webcasts } \\
\text { falando sobre } \\
\text { agilidade... Então, } \\
\text { basicamente, eu acho } \\
\text { que eu fui a primeira } \\
\text { pessoa que pegou esses } \\
\text { treinamentos e começou } \\
\text { a aplicar de fato". }\end{array}$ & $\begin{array}{l}\text { A primeira fase da } \\
\text { transição dependeu da } \\
\text { proatividade dos } \\
\text { líderes da organização, } \\
\text { pois não era } \\
\text { mandatória. }\end{array}$ & $\begin{array}{l}\text { "Eu apliquei com o } \\
\text { meu time. A 'galera' } \\
\text { gostou e começou a me } \\
\text { chamar. Aí a gestão viu } \\
\text { que tinha uma coisa } \\
\text { acontecendo lá na } \\
\text { Costa Rica que a gente } \\
\text { precisaria de alguém } \\
\text { para liderar. Falaram: } \\
\text { 'vai lá e vê se você } \\
\text { consegue fazer'. Aí, eu } \\
\text { fui". }\end{array}$ & $\begin{array}{l}\text { A segunda fase da transição } \\
\text { foi mais estruturada, } \\
\text { envolvendo um processo } \\
\text { global da organização, } \\
\text { aplicado em diversos países } \\
\text { de forma escalada. }\end{array}$ \\
\hline E5 & $\begin{array}{l}\text { "Acho que uma pressão } \\
\text { de alguns executivos do } \\
\text { conselho... O objetivo } \\
\text { deles era porque o } \\
\text { mercado está fazendo e } \\
\text { vocês [nós] têm } \\
\text { [tínhamos] que fazer } \\
\text { também. Não tinha } \\
\text { muito claro quais eram } \\
\text { os motivos... É um } \\
\text { pouco mais pela } \\
\text { modinha". }\end{array}$ & $\begin{array}{l}\text { A falta de um } \\
\text { motivador claro da } \\
\text { organização apresenta } \\
\text { um risco para a } \\
\text { transição, pois não fica } \\
\text { claro o objetivo que se } \\
\text { quer atingir. }\end{array}$ & & \\
\hline E6 & $\begin{array}{l}\text { "Foi o resultado de um } \\
\text { planejamento } \\
\text { estratégico feito em } \\
\text { parceria com a } \\
\text { Consultoria". }\end{array}$ & $\begin{array}{l}\text { O alinhamento da } \\
\text { transição ágil com o } \\
\text { planejamento } \\
\text { estratégico da } \\
\text { organização representa } \\
\text { um dos critérios de } \\
\text { sucesso da } \\
\text { transformação. }\end{array}$ & & \\
\hline
\end{tabular}




\begin{tabular}{|c|c|c|c|c|}
\hline \multirow{4}{*}{ 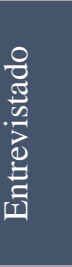 } & Unidade de Análise 2 & \multicolumn{3}{|c|}{ Preparação para a transição ágil (Continuação) } \\
\hline & Questão & \multicolumn{3}{|c|}{$\begin{array}{l}\text { Q1: Qual foi o principal motivador para a empresa decidir pelo projeto de } \\
\text { transformação ágil? }\end{array}$} \\
\hline & Subunidade & \multicolumn{3}{|c|}{ Motivador para a transformação } \\
\hline & Mensagem principal & $\begin{array}{c}\text { Interpretação da } \\
\text { mensagem principal }\end{array}$ & Mensagem associada & $\begin{array}{c}\text { Interpretação da } \\
\text { mensagem associada }\end{array}$ \\
\hline E7 & $\begin{array}{l}\text { "Foi para acompanhar o } \\
\text { mercado mesmo... E o } \\
\text { diretor que entrou tinha } \\
\text { uma Startup... Então, } \\
\text { ele trouxe isso muito } \\
\text { forte... Ele acreditava } \\
\text { muito na agilidade por } \\
\text { causa da própria Startup } \\
\text { dele e falou: 'agora a } \\
\text { gente vai ser ágil e } \\
\text { acabou'". }\end{array}$ & $\begin{array}{l}\text { A pressão interna para } \\
\text { a transição ágil pelos } \\
\text { executivos da } \\
\text { organização pode ser } \\
\text { considerada um risco, } \\
\text { caso seja executada de } \\
\text { forma top-down, sem a } \\
\text { análise da } \\
\text { aplicabilidade do } \\
\text { modelo na } \\
\text { organização. }\end{array}$ & & \\
\hline E8 & $\begin{array}{l}\text { "Eu entendo que é o } \\
\text { próprio mercado... A } \\
\text { Empresa sofreu uma } \\
\text { mudança de pessoas, e } \\
\text { as pessoas que vieram } \\
\text { trouxeram esse } \\
\text { framework". }\end{array}$ & $\begin{array}{l}\text { A transição dependeu } \\
\text { da proatividade dos } \\
\text { líderes da organização, } \\
\text { principalmente, em } \\
\text { decorrência dos novos } \\
\text { funcionários que } \\
\text { traziam o modelo ágil } \\
\text { do mercado. }\end{array}$ & & \\
\hline E9 & $\begin{array}{l}\text { "A empresa quis fazer } \\
\text { IPO em 2018, e para } \\
\text { isso fazia parte da tese } \\
\text { do banco avançar para o } \\
\text { mercado digital. Porque } \\
\text { qualquer banco hoje que } \\
\text { esteja fora dessa tese } \\
\text { digital, está fora do } \\
\text { mercado". }\end{array}$ & $\begin{array}{l}\text { O principal motivador } \\
\text { da organização foi a } \\
\text { nova concorrência do } \\
\text { mercado que, por ser } \\
\text { mais ágil, possui um } \\
\text { melhor time-to-market. }\end{array}$ & & \\
\hline E10 & $\begin{array}{l}\text { "Foi uma decisão do } \\
\text { Escritório de Projetos } \\
\text { com os diretores de } \\
\text { todas as áreas. Houve } \\
\text { uma reunião no final do } \\
\text { ano passado, e nessa } \\
\text { reunião foi dito: esse é } \\
\text { [era] o portfólio } \\
\text { estratégico para } 2020, \text { e } \\
\text { que esses projetos serão } \\
\text { [seriam] implementados } \\
\text { de maneira ágil". }\end{array}$ & $\begin{array}{l}\text { A pressão interna para } \\
\text { a transição ágil pelos } \\
\text { executivos da } \\
\text { organização pode ser } \\
\text { considerada um risco, } \\
\text { caso seja executada de } \\
\text { forma top-down, sem a } \\
\text { análise da } \\
\text { aplicabilidade do } \\
\text { modelo na } \\
\text { organização. }\end{array}$ & & \\
\hline MP & \multicolumn{4}{|c|}{$\begin{array}{l}\text { Dentre os motivadores para a transição ágil mencionados pelos entrevistados, os principais são a } \\
\text { necessidade de inovação pelas organizações e o lançamento de produtos no menor time-to-market. Esta } \\
\text { necessidade é constatada, principalmente, em organizações tradicionais, acostumadas a liderar no seu } \\
\text { segmento e que precisam reagir às novas startups para se manterem competitivas no mercado. Além } \\
\text { destes, também foram mencionadas tanto a necessidade de acompanhamento do mercado quanto a } \\
\text { decisão sobre a realização da transição de forma top-down pelos executivos da organização. Porém, } \\
\text { nestes casos, o impacto nos processos e na cultura foi muito maior. }\end{array}$} \\
\hline
\end{tabular}

Fonte: Quadro elaborado pela autora, com base nas entrevistas. 
b) Realização de assessment prévio

Quanto à realização de um assessment prévio para identificar o alinhamento do modelo ágil com a estratégia da organização, apenas quatro dos entrevistados (E1, E2, E5 e E6) tinham conhecimento sobre sua realização antes da tomada de decisão sobre a transição. Outros três entrevistados (E3, E7 e E9) informaram que a transição foi uma decisão executiva, sem a análise prévia da adequação da filosofia ágil à cultura da organização (Quadro 6).

Quadro 6 - Análise da coleta de dados: Preparação para a transição ágil - Realização de assessment prévio

\begin{tabular}{|c|c|c|c|c|}
\hline \multirow{4}{*}{ 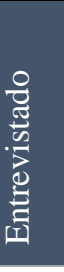 } & Unidade de Análise 2 & \multicolumn{3}{|c|}{ Preparação para a transição ágil } \\
\hline & Questão & \multicolumn{3}{|c|}{$\begin{array}{l}\text { Q2: Houve assessment prévio quanto à viabilidade da transição e o } \\
\text { alinhamento com os objetivos estratégicos? }\end{array}$} \\
\hline & Subunidade & \multicolumn{3}{|c|}{ Realização de assessment prévio } \\
\hline & Mensagem principal & $\begin{array}{l}\text { Interpretação da } \\
\text { mensagem principal }\end{array}$ & Mensagem associada & $\begin{array}{l}\text { Interpretação da } \\
\text { mensagem associada }\end{array}$ \\
\hline E1 & $\begin{array}{l}\text { "Foi alinhada com a } \\
\text { estratégia da empresa, } \\
\text { ser mais eficiente tanto } \\
\text { interna quanto } \\
\text { externamente". }\end{array}$ & $\begin{array}{l}\text { Houve um assessment } \\
\text { prévio e a transição ágil } \\
\text { foi de encontro ao } \\
\text { objetivo estratégico de } \\
\text { maior eficiência da } \\
\text { organização. }\end{array}$ & & \\
\hline E2 & $\begin{array}{l}\text { "A Consultoria } 1 \text { fez o } \\
\text { Planejamento } \\
\text { Estratégico, que foi um } \\
\text { projeto que olhou onde a } \\
\text { Empresa B gostaria de } \\
\text { estar daqui a } 5 \text { anos. Na } \\
\text { sequência, veio a } \\
\text { Consultoria 2, que fez } \\
\text { todo o processo de } \\
\text { Transformação Digital". }\end{array}$ & $\begin{array}{l}\text { Houve um assessment } \\
\text { prévio e a transição ágil } \\
\text { foi de encontro ao } \\
\text { objetivo estratégico da } \\
\text { organização. }\end{array}$ & & \\
\hline $\mathbf{E 3}$ & $\begin{array}{l}\text { "O que foi decidido é } \\
\text { que a gente precisava } \\
\text { entregar mais rápido. } \\
\text { Teve consultoria mais } \\
\text { para impor como seriam } \\
\text { as entregas, a } \\
\text { metodologia que a gente } \\
\text { iria trabalhar. Mas, se } \\
\text { teve realmente um } \\
\text { estudo, eu desconheço". }\end{array}$ & $\begin{array}{l}\text { A entrevistada } \\
\text { desconhece se houve um } \\
\text { assessment prévio. Foi } \\
\text { uma decisão dos } \\
\text { executivos da } \\
\text { organização. }\end{array}$ & $\begin{array}{l}\text { "O que chega para a } \\
\text { gente é que foi } \\
\text { decidido, eu não sei se } \\
\text { teve esse assessment". }\end{array}$ & $\begin{array}{l}\text { Embora a E3 seja da } \\
\text { mesma organização que } \\
\text { a E2, constatamos que } \\
\text { não houve } \\
\text { cascateamento das } \\
\text { informações em todos } \\
\text { os níveis da } \\
\text { organização. }\end{array}$ \\
\hline
\end{tabular}




\begin{tabular}{|c|c|c|c|c|}
\hline \multirow{4}{*}{ 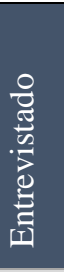 } & Unidade de Análise 2 & \multicolumn{3}{|c|}{ Preparação para a transição ágil (Continuação) } \\
\hline & Questão & \multicolumn{3}{|c|}{$\begin{array}{l}\text { Q2: Houve assessment prévio quanto à viabilidade da transição e o } \\
\text { alinhamento com os objetivos estratégicos? }\end{array}$} \\
\hline & Subunidade & \multicolumn{3}{|c|}{ Realização de assessment prévio } \\
\hline & Mensagem principal & $\begin{array}{l}\text { Interpretação da } \\
\text { mensagem principal }\end{array}$ & Mensagem associada & $\begin{array}{l}\text { Interpretação da } \\
\text { mensagem associada }\end{array}$ \\
\hline E5 & $\begin{array}{l}\text { "Isso começou a ser } \\
\text { feito no ano passado } \\
\text { quando veio a } \\
\text { consultoria... Antes do } \\
\text { ano passado foi mais } \\
\text { sensibilização". }\end{array}$ & $\begin{array}{l}\text { Houve um assessment } \\
\text { depois da contratação da } \\
\text { consultoria, quando foi } \\
\text { dado início à transição de } \\
\text { forma massiva. }\end{array}$ & $\begin{array}{l}\text { "Os objetivos } \\
\text { estratégicos são mais de } \\
\text { negócio e menos de } \\
\text { produtividade, e o ágil } \\
\text { fala mais de } \\
\text { produtividade. Não está } \\
\text { tão claro para eles ainda } \\
\text { que o ágil vai ajudar a } \\
\text { atingir alguns objetivos } \\
\text { estratégicos. Mas esse } \\
\text { trabalho já começou a } \\
\text { ser feito com alguns } \\
\text { executivos". }\end{array}$ & $\begin{array}{l}\text { Apesar de o modelo ágil } \\
\text { fazer parte do } \\
\text { planejamento } \\
\text { estratégico da } \\
\text { organização, não está } \\
\text { claro como ele irá } \\
\text { ajudar a atingir os } \\
\text { objetivos. }\end{array}$ \\
\hline E6 & $\begin{array}{l}\text { "Foi uma sugestão da } \\
\text { Consultoria que a gente } \\
\text { fosse para um caminho } \\
\text { de Business Agility... } \\
\text { Mas, até chegar lá, você } \\
\text { tem toda uma jornada... } \\
\text { Sugeriram que os novos } \\
\text { produtos de inovação } \\
\text { fossem executados no } \\
\text { modelo ágil". }\end{array}$ & $\begin{array}{l}\text { A transição ágil é apenas } \\
\text { o primeiro passo para o } \\
\text { reposicionamento } \\
\text { estratégico da } \\
\text { organização no longo } \\
\text { prazo. }\end{array}$ & & \\
\hline E7 & $\begin{array}{l}\text { "A gerente de } \\
\text { Governança... que } \\
\text { convenceu o comitê". }\end{array}$ & $\begin{array}{l}\text { A decisão dos } \\
\text { executivos, sem um } \\
\text { assessment se o modelo } \\
\text { ágil se encaixaria na } \\
\text { cultura da organização, } \\
\text { pode ser considerada um } \\
\text { risco para a transição. }\end{array}$ & & \\
\hline E9 & $\begin{array}{l}\text { "Nem cogitaram a } \\
\text { possibilidade de não ser } \\
\text { ágil... tudo o que é } \\
\text { digital é ágil... Então } \\
\text { não teve nem discussão, } \\
\text { ia ser assim e pronto". }\end{array}$ & $\begin{array}{l}\text { A decisão dos } \\
\text { executivos, sem um } \\
\text { assessment se o modelo } \\
\text { ágil se encaixaria na } \\
\text { cultura da organização, } \\
\text { pode ser considerada um } \\
\text { risco para a transição. }\end{array}$ & & \\
\hline MP & \multicolumn{4}{|c|}{$\begin{array}{l}\text { A realização do assessment é de extrema importância para identificar os objetivos da transição e o nível } \\
\text { de maturidade que se deseja atingir, além de avaliar o nível de aderência da organização aos processos } \\
\text { ágeis. A decisão dos executivos, sem um assessment se o modelo ágil se encaixaria na cultura da } \\
\text { organização, pode ser considerada um risco para a transição. }\end{array}$} \\
\hline
\end{tabular}

Fonte: Quadro elaborado pela autora, com base nas entrevistas.

c) Aplicação de framework de transição

A aplicação de framework de transição pela consultoria contratada ou pela equipe de transição interna pode contribuir para a adoção de um processo estruturado e para a análise 
dos resultados de forma efetiva. Três dos entrevistados (E1, E2 e E3) não se lembraram se houve a aplicação de framework durante a transição. Outros três entrevistados (E4, E5 e E7) informaram que a consultoria contratada aplicou um processo de transição para a realização dos treinamentos, avaliação do nível de maturidade, acompanhamento dos resultados com os times e replicação do modelo de forma escalada. O entrevistado E6 buscou consultorias que não apresentassem um framework pronto, com o objetivo de construir um modelo adaptado à organização. O entrevistado E8, por sua vez, explicou que a contratação do Agile Coach, externo à organização, foi feita no modelo on demand, apenas atuando pontualmente na orientação das equipes (Quadro 7).

Quadro 7 - Análise da coleta de dados: Preparação para a transição ágil - Aplicação de framework de transição

\begin{tabular}{|c|c|c|c|c|}
\hline \multirow{4}{*}{ 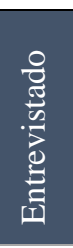 } & \multirow{3}{*}{$\begin{array}{l}\text { Unidade de Análise } 2 \\
\text { Questão } \\
\text { Subunidade }\end{array}$} & \multicolumn{3}{|c|}{ Preparação para a transição ágil } \\
\hline & & \multicolumn{3}{|c|}{ Q5: Houve a aplicação de um processo de transição ou framework? } \\
\hline & & \multicolumn{3}{|c|}{ Aplicação de framework de transição } \\
\hline & Mensagem principal & $\begin{array}{c}\text { Interpretação da } \\
\text { mensagem principal }\end{array}$ & Mensagem associada & $\begin{array}{c}\text { Interpretação da } \\
\text { mensagem associada }\end{array}$ \\
\hline E1 & $\begin{array}{l}\text { "Na época, foi } \\
\text { divulgado, mas eu não } \\
\text { me lembro } \\
\text { exatamente". }\end{array}$ & $\begin{array}{l}\text { O entrevistado não se } \\
\text { lembrou se houve a } \\
\text { aplicação de um } \\
\text { framework, porém } \\
\text { descreveu } \\
\text { posteriormente algumas } \\
\text { fases da transição. }\end{array}$ & $\begin{array}{l}\text { "Primeiro, teve uma } \\
\text { onda de treinamentos } \\
\text { com as áreas e depois } \\
\text { eles aplicaram um } \\
\text { assessment, um } \\
\text { questionário para } \\
\text { medir o nível de } \\
\text { maturidade do ágil nas } \\
\text { equipes. Após o piloto, } \\
\text { eles aplicaram o } \\
\text { assessment novamente } \\
\text { para verificar a } \\
\text { evolução". }\end{array}$ & $\begin{array}{l}\text { A transição contemplou um } \\
\text { assessment do nível de } \\
\text { maturidade da empresa; } \\
\text { uma fase de treinamentos; e } \\
\text { um assessment posterior } \\
\text { para avaliar a evolução do } \\
\text { nível de maturidade. }\end{array}$ \\
\hline E2 & $\begin{array}{l}\text { "Eu não sei se eles } \\
\text { [Consultoria] vieram } \\
\text { com algum framework } \\
\text { de prateleira. Mas, eu } \\
\text { imagino que quando } \\
\text { eles entenderam como } \\
\text { funciona a Empresa B e } \\
\text { quais eram os nossos } \\
\text { desafios... eles devem } \\
\text { ter proposto alguma } \\
\text { customização em cima } \\
\text { de um framework que } \\
\text { eles conhecem". }\end{array}$ & $\begin{array}{l}\text { O entrevistado não se } \\
\text { lembrou se houve a } \\
\text { aplicação de um } \\
\text { framework. }\end{array}$ & & \\
\hline E3 & $\begin{array}{l}\text { "Eu não me lembro... A } \\
\text { gente olhava mais } \\
\text { aquele mundinho ali do } \\
\text { projeto mesmo". }\end{array}$ & $\begin{array}{l}\text { O entrevistado não se } \\
\text { lembrou se houve a } \\
\text { aplicação de um } \\
\text { framework. }\end{array}$ & & \\
\hline
\end{tabular}




\begin{tabular}{|c|c|c|c|c|}
\hline \multirow{4}{*}{ 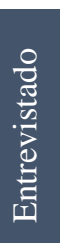 } & Unidade de Análise 2 & \multicolumn{3}{|c|}{ Preparação para a transição ágil (Continuação) } \\
\hline & Questão & \multicolumn{3}{|c|}{ Q5: Houve a aplicação de um processo de transição ou framework? } \\
\hline & Subunidade & \multicolumn{3}{|c|}{ Aplicação de framework de transição } \\
\hline & Mensagem principal & $\begin{array}{c}\text { Interpretação da } \\
\text { mensagem principal }\end{array}$ & Mensagem associada & $\begin{array}{c}\text { Interpretação da } \\
\text { mensagem associada }\end{array}$ \\
\hline $\mathbf{E 4}$ & $\begin{array}{l}\text { "A gente tinha o desafio } \\
\text { de fazer } 1500 \text { pessoas, } \\
\text { depois } 5000 \text {, então a } \\
\text { gente precisava de um } \\
\text { modelo, não dava para } \\
\text { fazer só corpo a corpo } \\
\text { com os times como eu } \\
\text { fazia". }\end{array}$ & $\begin{array}{l}\text { Houve a aplicação de } \\
\text { um framework apenas } \\
\text { na segunda fase da } \\
\text { transição, para } \\
\text { replicação do modelo } \\
\text { em várias áreas. }\end{array}$ & & \\
\hline E5 & $\begin{array}{l}\text { "Primeiro, a imersão } \\
\text { para a gente definir... } \\
\text { como a gente ia } \\
\text { trabalhar... Depois, uma } \\
\text { onda de treinamentos. } \\
\text { Depois, trabalho de } \\
\text { campo, nova onda de } \\
\text { treinamento e trabalho } \\
\text { de campo. Isso } \\
\text { pensando na esteira } \\
\text { implementada". }\end{array}$ & $\begin{array}{l}\text { Houve a definição de } \\
\text { um modelo de } \\
\text { implantação de cada } \\
\text { área, incluindo as fases } \\
\text { de imersão, treinamento } \\
\text { e trabalho de campo. }\end{array}$ & & \\
\hline E6 & $\begin{array}{l}\text { "Era uma coisa que eu } \\
\text { estava fugindo, da } \\
\text { forma pronta... Tinha } \\
\text { uma metodologia de } \\
\text { trabalho... mas, foi tudo } \\
\text { feito a } 4 \text { mãos... A gente } \\
\text { fechou em } 3 \text { frentes que } \\
\text { a gente chamou de } \\
\text { Capacitação, Coaching } \\
\text { e Guidance". }\end{array}$ & $\begin{array}{l}\text { É importante que o } \\
\text { processo de } \\
\text { transformação utilizado } \\
\text { seja adaptado à } \\
\text { realidade da } \\
\text { organização. }\end{array}$ & $\begin{array}{l}\text { "Fizemos um modelo } \\
\text { de maturidade, } \\
\text { pegando ali boas } \\
\text { práticas... O projeto } \\
\text { durou um ano } \\
\text { inicialmente, e de } 2 \text { em } \\
2 \text { meses a gente rodava } \\
\text { esse assessment". }\end{array}$ & $\begin{array}{l}\text { Houve assessment prévio } \\
\text { para avaliar o nível de } \\
\text { maturidade das equipes. } \\
\text { A aplicação periódica do } \\
\text { assessment para avaliar o } \\
\text { nível de maturidade das } \\
\text { equipes é uma estratégia } \\
\text { eficiente para avaliar os } \\
\text { resultados da transição. }\end{array}$ \\
\hline E7 & $\begin{array}{l}\text { "A Consultoria trouxe o } \\
\text { framework próprio, pois } \\
\text { ela é muito madura em } \\
\text { agilidade... Eles } \\
\text { começaram } \\
\text { introduzindo sprint... Aí } \\
\text { eles deram vários } \\
\text { treinamentos sobre o } \\
\text { scrum, o que o scrum } \\
\text { agrega... Depois que } \\
\text { cada unidade já sabia } \\
\text { rodar o scrum, a gente } \\
\text { foi falar sobre release". }\end{array}$ & $\begin{array}{l}\text { Houve a aplicação de } \\
\text { um modelo de } \\
\text { treinamento das squads, } \\
\text { a partir dos princípios } \\
\text { ágeis, ressaltando a } \\
\text { importância de cada } \\
\text { conceito e agregando } \\
\text { novas funcionalidades à } \\
\text { medida que as equipes } \\
\text { foram se tornando } \\
\text { sólidas. }\end{array}$ & $\begin{array}{l}\text { "Isso aí é importante, } \\
\text { você não pode chegar } \\
\text { arregaçando, agora } \\
\text { todo mundo vai rodar } \\
\text { ágil... Primeiro fizeram } \\
\text { toda a estrutura ali para } \\
\text { depois ir construindo } \\
\text { blocos maiores em } \\
\text { cima com outros } \\
\text { conceitos". }\end{array}$ & $\begin{array}{l}\text { A entrevistada ressaltou a } \\
\text { importância do treinamento } \\
\text { de forma gradual, } \\
\text { primeiramente trazendo os } \\
\text { principais conceitos ágeis e, } \\
\text { depois, incrementando com } \\
\text { as demais funcionalidades. }\end{array}$ \\
\hline
\end{tabular}




\begin{tabular}{|c|c|c|c|c|}
\hline & Unidade de Análise 2 & \multicolumn{3}{|c|}{ Preparação para a transição ágil (Continuação) } \\
\hline & Questão & \multicolumn{3}{|c|}{ Q5: Houve a aplicação de um processo de transição ou framework? } \\
\hline & Subunidade & \multicolumn{3}{|c|}{ Aplicação de framework de transição } \\
\hline 节 & Mensagem principal & $\begin{array}{c}\text { Interpretação da } \\
\text { mensagem principal }\end{array}$ & Mensagem associada & $\begin{array}{c}\text { Interpretação da } \\
\text { mensagem associada }\end{array}$ \\
\hline E8 & $\begin{array}{l}\text { "Conhecendo as pessoas } \\
\text { que trouxeram isso. } \\
\text { Acho que foi um Go } \\
\text { Horse total... É uma } \\
\text { pessoa da consultoria } \\
\text { que vai, mas, ele vai on } \\
\text { demand para a gente. } \\
\text { Ele faz alguns eventos } \\
\text { com a gente; facilita } \\
\text { algumas reuniões... } \\
\text { Mas, assim, é um } \\
\text { trabalho pontual, então } \\
\text { ele vê como a gente está } \\
\text { trabalhando... a gente } \\
\text { pede orientação". }\end{array}$ & $\begin{array}{l}\text { Não há um processo } \\
\text { definido para a } \\
\text { transição ágil. O Agile } \\
\text { Coach apoia as equipes } \\
\text { sob demanda. }\end{array}$ & $\begin{array}{l}\text { "Não tinha um plano } \\
\text { de trabalho. E são } \\
\text { coisas que a gente vai } \\
\text { vendo no meio do } \\
\text { caminho. Então não } \\
\text { estava estruturado um } \\
\text { script... até porque não } \\
\text { faz muito sentido, né? } \\
\text { Isso é mais do } \\
\text { 'GPzão', né, ter um } \\
\text { plano. Tem que ir } \\
\text { sentindo como as } \\
\text { pessoas vão". }\end{array}$ & $\begin{array}{l}\text { A entrevistada acredita que } \\
\text { o modelo ágil não requer } \\
\text { um plano, nem mesmo } \\
\text { durante o período de } \\
\text { transição. }\end{array}$ \\
\hline & \multicolumn{4}{|c|}{$\begin{array}{l}\text { A aplicação de um framework de transição muitas vezes não foi percebida pelos entrevistados. Porém, } \\
\text { mesmo nestes casos, constatamos que foi aplicado um processo estruturado pela equipe de transição. Os } \\
\text { frameworks incluem o plano de implantação e o escalonamento do modelo ágil, bem como o catálogo de } \\
\text { treinamentos e o acompanhamento das equipes adaptados ao contexto da organização. Em alguns casos, } \\
\text { incluíram também os assessments iniciais e os periódicos para avaliar a evolução do nível de maturidade } \\
\text { ágil das equipes. As transições realizadas sob demanda, sem um planejamento ou aplicação de um modelo } \\
\text { estruturado, impactam o engajamento das equipes e aumentam o abandono das novas práticas. }\end{array}$} \\
\hline
\end{tabular}

Fonte: Quadro elaborado pela autora, com base nas entrevistas.

d) Organização preparada

Cinco dos entrevistados (E1, E4, E5, E6 e E7) acreditavam que a organização estava preparada para o modelo ágil e que a transição ocorreu no momento adequado. Já os entrevistados E2, E3, E9 e E10 entenderam que a organização não estava preparada para o modelo ágil. Eles mencionaram que os principais motivos para isso foram a cultura tradicional da organização e a realização do processo de forma top-down, sem o devido cuidado com as pessoas e com os processos atuais (Quadro 8). 
Quadro 8 - Análise da coleta de dados: Preparação para a transição ágil - Organização preparada

\begin{tabular}{|c|c|c|c|c|}
\hline \multirow{4}{*}{ 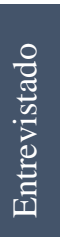 } & Unidade de Análise 2 & \multicolumn{3}{|c|}{ Preparação para a transição ágil } \\
\hline & Questão & \multicolumn{3}{|c|}{ Q28: A empresa estava preparada para a transição? } \\
\hline & Subunidade & \multicolumn{3}{|l|}{ Organização preparada } \\
\hline & Mensagem principal & $\begin{array}{l}\text { Interpretação da } \\
\text { mensagem principal }\end{array}$ & Mensagem associada & $\begin{array}{l}\text { Interpretação da } \\
\text { mensagem associada }\end{array}$ \\
\hline E1 & $\begin{array}{l}\text { "A empresa estava } \\
\text { preparada e absorveu } \\
\text { bem a transição... Já } \\
\text { estava buscando uma } \\
\text { nova cultura com } \\
\text { mais colaboração". }\end{array}$ & $\begin{array}{l}\text { A percepção da } \\
\text { entrevistada foi de que } \\
\text { a empresa estava } \\
\text { preparada para } \\
\text { absorver a cultura ágil } \\
\text { naquele momento. }\end{array}$ & & \\
\hline E2 & $\begin{array}{l}\text { "Não estávamos... As } \\
\text { pessoas... claramente, } \\
\text { muitas delas foram } \\
\text { jogadas lá em papéis } \\
\text { que elas não } \\
\text { dominavam. Mas, } \\
\text { assim, eu acho que } \\
\text { não dava mais para } \\
\text { esperar". }\end{array}$ & $\begin{array}{l}\text { A transição foi } \\
\text { realizada sem ter } \\
\text { cuidado com as pessoas } \\
\text { e com os novos } \\
\text { processos. }\end{array}$ & $\begin{array}{l}\text { "Eu acho que foi uma } \\
\text { decisão estratégica da } \\
\text { companhia, a gente já } \\
\text { sabia que ia ter } \\
\text { efeitos colaterais, } \\
\text { mas eu acho que... } \\
\text { essa mudança tinha } \\
\text { que acontecer". }\end{array}$ & $\begin{array}{l}\text { Mesmo a organização } \\
\text { não estando preparada, a } \\
\text { transformação tinha que } \\
\text { ocorrer para que ela } \\
\text { conseguisse se } \\
\text { posicionar frente à } \\
\text { concorrência. }\end{array}$ \\
\hline $\mathbf{E 3}$ & $\begin{array}{l}\text { "Não estava } \\
\text { preparada, foi top- } \\
\text { down, na mudança de } \\
\text { presidente. Ele veio } \\
\text { muito com esse olhar } \\
\text { de 'temos que ser } \\
\text { ágeis e fim'... Então, } \\
\text { eu acho que foi bem } \\
\text { brusca a } \\
\text { transformação... por } \\
\text { isso que não está } \\
\text { sendo fácil". }\end{array}$ & $\begin{array}{l}\text { A transição foi } \\
\text { realizada sem ter } \\
\text { cuidado com as pessoas } \\
\text { e com os novos } \\
\text { processos, de forma } \\
\text { top-down. }\end{array}$ & $\begin{array}{l}\text { "Vai ter que adaptar, } \\
\text { é um caminho sem } \\
\text { volta. Não tem como } \\
\text { falar 'vamos voltar ao } \\
\text { que era antes'. Isso } \\
\text { não existe". }\end{array}$ & $\begin{array}{l}\text { Mesmo a empresa não } \\
\text { estando preparada, a } \\
\text { transformação tinha que } \\
\text { ocorrer para que a } \\
\text { organização conseguisse } \\
\text { se posicionar frente à } \\
\text { concorrência. }\end{array}$ \\
\hline $\mathbf{E 4}$ & $\begin{array}{l}\text { "Sim. A Empresa } \\
\text { começou bem } \\
\text { depois... Ela fez no } \\
\text { tempo dela". }\end{array}$ & $\begin{array}{l}\text { A percepção da } \\
\text { entrevistada foi de que } \\
\text { a empresa estava } \\
\text { preparada para } \\
\text { absorver a cultura ágil } \\
\text { naquele momento. }\end{array}$ & & \\
\hline E5 & $\begin{array}{l}\text { "Eu acho que estava } \\
\text { no momento } \\
\text { oportuno". }\end{array}$ & $\begin{array}{l}\text { A percepção do } \\
\text { entrevistado foi de que } \\
\text { a empresa estava } \\
\text { preparada para } \\
\text { absorver a cultura ágil } \\
\text { naquele momento. }\end{array}$ & & \\
\hline E6 & $\begin{array}{l}\text { "Estava. Estava até } \\
\text { um pouquinho } \\
\text { atrasada". }\end{array}$ & $\begin{array}{l}\text { A percepção do } \\
\text { entrevistado foi de que } \\
\text { a empresa estava } \\
\text { preparada para } \\
\text { absorver a cultura ágil, } \\
\text { porém a transição já } \\
\text { deveria ter sido iniciada } \\
\text { anteriormente. }\end{array}$ & & \\
\hline
\end{tabular}

(Continua) 


\begin{tabular}{|c|c|c|c|c|}
\hline \multirow{4}{*}{ 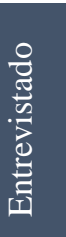 } & Unidade de Análise 2 & \multicolumn{3}{|c|}{ Preparação para a transição ágil (Continuação) } \\
\hline & Questão & \multicolumn{3}{|c|}{ Q28: A empresa estava preparada para a transição? } \\
\hline & Subunidade & \multicolumn{3}{|l|}{ Organização preparada } \\
\hline & Mensagem principal & $\begin{array}{l}\text { Interpretação da } \\
\text { mensagem principal }\end{array}$ & Mensagem associada & $\begin{array}{l}\text { Interpretação da } \\
\text { mensagem associada }\end{array}$ \\
\hline E7 & $\begin{array}{l}\text { "Eu acho que o time } \\
\text { acompanhou bem. } \\
\text { Quem se adaptou, } \\
\text { acompanhou bem. } \\
\text { Quem não se adaptou, } \\
\text { saiu". }\end{array}$ & $\begin{array}{l}\text { A percepção do } \\
\text { entrevistado foi de que } \\
\text { a empresa estava } \\
\text { preparada para } \\
\text { absorver a cultura ágil. } \\
\text { Seria natural que } \\
\text { houvesse pessoas mais } \\
\text { resistentes, que não se } \\
\text { adaptassem às } \\
\text { mudanças. }\end{array}$ & & \\
\hline E9 & $\begin{array}{l}\text { "Tem um tema de } \\
\text { Change Management } \\
\text { aí muito forte, de } \\
\text { cultura, que foi um } \\
\text { choque...Acultura da } \\
\text { Empresa é um dos } \\
\text { nossos maiores } \\
\text { desafios. É um } \\
\text { banco... muito } \\
\text { tradicional, que tinha } \\
\text { uma cultura } \\
\text { hierárquica muito } \\
\text { forte de comando e } \\
\text { controle. E aí você } \\
\text { sair de uma empresa } \\
\text { de comando e } \\
\text { controle para ir para o } \\
\text { mundo da agilidade é } \\
\text { muito difícil". }\end{array}$ & $\begin{array}{l}\text { A organização não } \\
\text { estava preparada para a } \\
\text { nova cultura do modelo } \\
\text { ágil. }\end{array}$ & $\begin{array}{l}\text { "Acho que a gente já } \\
\text { está mega atrasado. } \\
\text { Eu acho que eles já } \\
\text { deviam ter feito isso } \\
\text { há muito tempo... A } \\
\text { gente tinha que ter } \\
\text { feito esse movimento } \\
2 \text { anos antes do IPO... } \\
\text { E eles começaram } \\
\text { praticamente com o } \\
\text { plano de avançar o } \\
\text { IPO, foi muito } \\
\text { errado". }\end{array}$ & $\begin{array}{l}\text { Mesmo a empresa não } \\
\text { estando preparada, a } \\
\text { transformação tinha que } \\
\text { ocorrer para que a } \\
\text { organização conseguisse } \\
\text { se posicionar frente à } \\
\text { concorrência. }\end{array}$ \\
\hline E10 & $\begin{array}{l}\text { "O Escritório de } \\
\text { Projetos pediu para } \\
\text { que eu implementasse } \\
\text { o modelo ágil. Só que } \\
\text { as lideranças não } \\
\text { acreditam } \\
\text { [acreditavam] nesse } \\
\text { [naquele] modelo. } \\
\text { Então. tem um } \\
\text { processo de } \\
\text { transformação cultural } \\
\text { em andamento, forte". }\end{array}$ & $\begin{array}{l}\text { A organização não } \\
\text { estava preparada para a } \\
\text { nova cultura do modelo } \\
\text { ágil e ainda há muita } \\
\text { resistência por parte } \\
\text { das pessoas. }\end{array}$ & & \\
\hline MP & $\begin{array}{l}\text { Os entrevistados que } \\
\text { referiram-se à falta de } \\
\text { comando e controle) e } \\
\text { que as organizações te } \\
\text { níveis executivos quan } \\
\text { menos resistência à m } \\
\text { entrevistados entender } \\
\text { casos, ela já deveria te } \\
\text { frente à nova concorrêr }\end{array}$ & $\begin{array}{l}\text { onsideraram que a organ } \\
\text { alinhamento com sua cu } \\
\text { à realização da transição } \\
\text { nham cuidado com as pe } \\
\text { to nos operacionais, para } \\
\text { ddança. Mesmo nos caso } \\
\text { am que a transição ágil } \\
\text { ocorrido anteriormente, } \\
\text { cia. }\end{array}$ & $\begin{array}{l}\text { hização não estava pre } \\
\text { ltura atual (por exemp } \\
\text { de forma top-down. Po } \\
\text { essoas durante o proces } \\
\text { que elas acreditem no } \\
\text { s em que a organizaçã } \\
\text { era mandatória para a } \\
\text { para que a organização }\end{array}$ & $\begin{array}{l}\text { arada para o modelo ágil } \\
\text { o, culturas tradicionais de } \\
\text { este motivo, é importante } \\
\text { so de transição, tanto nos } \\
\text { novo modelo e ofereçam } \\
\text { não estava preparada, os } \\
\text { organização e, em muitos } \\
\text { conseguisse se posicionar }\end{array}$ \\
\hline
\end{tabular}

Fonte: Quadro elaborado pela autora, com base nas entrevistas. 
4.2.1.3 Resultados da transição - coleta de dados primários (UA 3)

A transição para o modelo ágil gera impacto na cultura da organização, principalmente no início do processo, quando as equipes ainda não estão adaptadas ao novo modelo. A recomendação da literatura é que a organização adote um processo de melhoria contínua e considere a curva de conhecimento como parte do processo.

\section{a) Benefícios da transição}

O maior benefício do modelo ágil, mencionado por cinco dos entrevistados (E1, E2, E3, E4, E6 e E8), foi a redução do tempo de entrega dos projetos de desenvolvimento. Três dos entrevistados (E2, E8 e E9) também mencionaram o aumento na quantidade de entregas. Os motivos para esta melhoria foram a proximidade entre as áreas de Negócios e a de Tecnologia e a composição da Squad por uma equipe multidisciplinar, que já realizava as atividades de desenvolvimento e testes.

O modelo ágil também resultou em uma melhor qualidade técnica dos desenvolvimentos de software, com menos incidentes em produção, como mencionado por três dos entrevistados (E2, E4 e E6), e na alteração de processos, de acordo com o conceito de melhoria contínua. Além disso, os entrevistados E7 e E9 relataram que as organizações começaram a avaliar melhor as demandas e a implementar apenas aquelas que realmente agregavam valor para o negócio, utilizando o critério de priorização do modelo ágil. Outros dois entrevistados (E2 e E7) mencionaram a transparência e a visibilidade do modelo ágil como os seus principais benefícios.

No que diz respeito às pessoas, os entrevistados E1, E4, E7, E8 e E9 mencionaram benefícios internos na equipe, incluindo maior autonomia, colaboração e engajamento, além de maior satisfação do cliente devido à proximidade com a equipe de desenvolvimento.

O custo dos projetos foi mencionado como um ponto positivo, segundo o entrevistado E4, porém, como um ponto negativo, segundo os entrevistados E2, E6 e E9, devido ao alto custo para manter as equipes dedicadas no modelo ágil. Alguns outros pontos negativos foram mencionados isoladamente pelos entrevistados E2 e E6. Porém, todos entendem que a implantação do modelo ágil trouxe muito mais pontos positivos do que negativos para a organização (Quadro 9). 
Quadro 9 - Análise da coleta de dados: Resultados da transição - Benefícios da transição

\begin{tabular}{|c|c|c|c|c|}
\hline \multirow{4}{*}{$\cdot \frac{0}{0}$} & Unidade de Análise 3 & \multicolumn{3}{|l|}{ Resultados da transição } \\
\hline & Questão & \multicolumn{3}{|c|}{$\begin{array}{l}\text { Q21: O que mudou nos projetos depois da transição para o modelo ágil? O } \\
\text { que melhorou ou piorou (tempo, custo, qualidade)? }\end{array}$} \\
\hline & Subunidade & \multicolumn{3}{|l|}{ Benefícios da transição } \\
\hline & Mensagem principal & $\begin{array}{l}\text { Interpretação da } \\
\text { mensagem principal }\end{array}$ & Mensagem associada & $\begin{array}{c}\text { Interpretação da } \\
\text { mensagem associada }\end{array}$ \\
\hline E1 & $\begin{array}{l}\text { "Melhorou muito ter as } \\
\text { áreas de } \\
\text { desenvolvimento e as de } \\
\text { testes na mesma squad... } \\
\text { a autonomia das pessoas, } \\
\text { dos analistas... Os } \\
\text { projetos estão mais } \\
\text { alinhados entre a área } \\
\text { técnica e a de negócio... } \\
\text { Novos produtos foram } \\
\text { entregues de forma mais } \\
\text { rápida para o mercado". }\end{array}$ & $\begin{array}{l}\text { Entrega mais rápida, } \\
\text { autonomia da equipe, } \\
\text { alinhamento entre a área } \\
\text { de negócios e } \\
\text { tecnologia. }\end{array}$ & $\begin{array}{l}\text { "Como o negócio da } \\
\text { empresa é regulado, } \\
\text { alguns processos não } \\
\text { conseguem entrar no } \\
\text { ágil e as áreas usam isso } \\
\text { como muleta". }\end{array}$ & $\begin{array}{l}\text { Dificuldade em incluir a } \\
\text { agilidade no negócio } \\
\text { regulado. }\end{array}$ \\
\hline E2 & $\begin{array}{l}\text { "Aumentou a nossa } \\
\text { velocidade de entrega, } \\
\text { quantidade de entregas e } \\
\text { qualidade nas entregas... } \\
\text { quantidade de incidentes, } \\
\text { rollback". }\end{array}$ & $\begin{array}{l}\text { Entrega mais rápida, } \\
\text { quantidade de entregas, } \\
\text { qualidade da entrega. }\end{array}$ & $\begin{array}{l}\text { "Está muito caro rampar } \\
\text { uma squad... em } \\
\text { projetos poderia ser } \\
\text { mais caro... mas, eu } \\
\text { acho que ainda assim é } \\
\text { um custo alto para } \\
\text { organização". }\end{array}$ & $\begin{array}{l}\text { Custo da estrutura de } \\
\text { squads muito elevado, } \\
\text { pois requer equipes } \\
\text { dedicadas. }\end{array}$ \\
\hline $\mathbf{E 3}$ & "Entregas mais rápidas". & Entrega mais rápida. & $\begin{array}{l}\text { "Se posicionar mais no } \\
\text { mercado". }\end{array}$ & $\begin{array}{l}\text { A entrega mais rápida } \\
\text { possibilitou à empresa } \\
\text { retomar o time-to- } \\
\text { market. }\end{array}$ \\
\hline E4 & $\begin{array}{l}\text { "Satisfação do time... O } \\
\text { tempo dos projetos } \\
\text { reduziu... também } \\
\text { reduziu os custos... } \\
\text { Aumentou o retorno da } \\
\text { empresa sobre esses } \\
\text { projetos... qualidade } \\
\text { também a gente teve } \\
\text { melhoria". }\end{array}$ & $\begin{array}{l}\text { Entrega mais rápida, } \\
\text { satisfação da equipe, } \\
\text { qualidade da entrega e } \\
\text { retorno sobre os } \\
\text { projetos. }\end{array}$ & & \\
\hline E5 & $\begin{array}{l}\text { "Hoje o PMO não sabe } \\
\text { dizer quanto tempo a } \\
\text { gente demora para } \\
\text { entregar um projeto. } \\
\text { Então não tem como eu } \\
\text { dizer que eu demorava } \\
\text { tanto e depois do ágil } \\
\text { passei a demorar tanto". }\end{array}$ & $\begin{array}{l}\text { Não existem métricas } \\
\text { para analisar os } \\
\text { benefícios da transição } \\
\text { ágil. }\end{array}$ & $\begin{array}{l}\text { "O ferramental não está } \\
\text { ajudando... Eu não } \\
\text { tenho a comparação } \\
\text { com o antes porque eu } \\
\text { não tenho essa } \\
\text { informação". }\end{array}$ & $\begin{array}{l}\text { Faltam ferramentas } \\
\text { apropriadas para medir e } \\
\text { comparar os resultados } \\
\text { de entrega dos projetos } \\
\text { depois da transição ágil. }\end{array}$ \\
\hline E6 & $\begin{array}{l}\text { "A gente levava um ano } \\
\text { e meio... e a gente } \\
\text { começou a conseguir pôr } \\
\text { o produto no mercado } \\
\text { em } 6,8 \text { meses... } \\
\text { Melhorou a qualidade da } \\
\text { entrega". }\end{array}$ & $\begin{array}{l}\text { Entrega mais rápida e } \\
\text { qualidade da entrega. }\end{array}$ & $\begin{array}{l}\text { "O custo não teve como } \\
\text { mensurar, aí é } \\
\text { percepção, não é } \\
\text { dado... primeira } \\
\text { sensação de que é mais } \\
\text { caro... porque você } \\
\text { trabalha dedicado". }\end{array}$ & $\begin{array}{l}\text { Custo da estrutura de } \\
\text { squads é muito elevado, } \\
\text { pois requer equipes } \\
\text { dedicadas. }\end{array}$ \\
\hline
\end{tabular}

(Continua) 


\begin{tabular}{|c|c|c|c|c|}
\hline \multirow{4}{*}{ 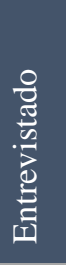 } & Unidade de Análise 3 & \multicolumn{3}{|c|}{ Resultados da transição (Continuação) } \\
\hline & Questão & \multicolumn{3}{|c|}{$\begin{array}{l}\text { Q21: O que mudou nos projetos depois da transição para o modelo ágil? O } \\
\text { que melhorou ou piorou (tempo, custo, qualidade)? }\end{array}$} \\
\hline & Subunidade & \multicolumn{3}{|l|}{ Benefícios da transição } \\
\hline & Mensagem principal & $\begin{array}{c}\text { Interpretação da } \\
\text { mensagem principal }\end{array}$ & Mensagem associada & $\begin{array}{c}\text { Interpretação da } \\
\text { mensagem associada }\end{array}$ \\
\hline E7 & $\begin{array}{l}\text { " Eu vi um benefício } \\
\text { muito grande... teve } \\
\text { realmente essa } \\
\text { transparência muito } \\
\text { maior... O cliente final } \\
\text { está muito mais } \\
\text { satisfeito, porque... } \\
\text { estava mais claro o que } \\
\text { ia ser entregue pelo } \\
\text { menos no trimestre". }\end{array}$ & $\begin{array}{l}\text { Transparência, } \\
\text { alinhamento de negócios } \\
\text { e tecnologia. }\end{array}$ & & \\
\hline E8 & $\begin{array}{l}\text { "Estamos muito mais } \\
\text { organizados... Ficou } \\
\text { melhor [o tempo dos } \\
\text { projetos] porque a gente } \\
\text { consegue avaliar... a } \\
\text { retrospectiva é o segredo } \\
\text { do negócio, você parar, } \\
\text { olhar, ver o que foi bom, } \\
\text { o que precisa mudar... } \\
\text { Não é fruto só da } \\
\text { agilidade... O que } \\
\text { prevalece... é a sinergia } \\
\text { do time... A gente fez } \\
\text { muita entrega no ano } \\
\text { passado". }\end{array}$ & $\begin{array}{l}\text { Entrega mais rápida, } \\
\text { quantidade de entregas, } \\
\text { processo mais } \\
\text { organizado, melhoria } \\
\text { contínua para melhoria } \\
\text { de processos e sinergia } \\
\text { da equipe. }\end{array}$ & $\begin{array}{l}\text { "O time está começando } \\
\text { ainda... Então não está } \\
\text { com a mesma } \\
\text { velocidade... Daqui a } \\
\text { pouco vai ter } \\
\text { transição... Tem gente } \\
\text { que está chegando, tem } \\
\text { gente que vai sair... } \\
\text { Vocês vão ter que } \\
\text { considerar as } \\
\text { velocidades dessas } \\
\text { transições". }\end{array}$ & $\begin{array}{l}\text { O alto turnover da } \\
\text { organização deve ser } \\
\text { considerado para } \\
\text { calcular a velocidade da } \\
\text { entrega da equipe. }\end{array}$ \\
\hline E9 & $\begin{array}{l}\text { "Entregar mais... engajar } \\
\text { mais funcionários, } \\
\text { porque eles têm mais } \\
\text { autonomia na tomada de } \\
\text { decisão... Fazer com que } \\
\text { todo mundo olhasse os } \\
\text { números do BP... } \\
\text { objetivos muito claros... } \\
\text { Melhorou } \\
\text { direcionamento... as } \\
\text { pessoas passaram a } \\
\text { acreditar e quebrou } \\
\text { muito a resistência". }\end{array}$ & $\begin{array}{l}\text { Quantidade de entregas, } \\
\text { autonomia da equipe, } \\
\text { menor resistência. } \\
\text { OKR resultou em } \\
\text { melhor direcionamento } \\
\text { estratégico. }\end{array}$ & $\begin{array}{l}\text { "Percepção de que os } \\
\text { times legados do } \\
\text { modelo cascata } \\
\text { entregam muito mais... } \\
\text { Gente que está há muito } \\
\text { tempo fazendo a mesma } \\
\text { coisa... Difícil garantir } \\
\text { entrega para um time } \\
\text { muito novo, no mesmo } \\
\text { ritmo que um time que } \\
\text { está há } 20 \text { anos } \\
\text { trabalhando com a } \\
\text { mesma coisa". }\end{array}$ & $\begin{array}{l}\text { A percepção da } \\
\text { organização é de que o } \\
\text { custo aumentou com o } \\
\text { modelo ágil, devido à } \\
\text { curva de conhecimento } \\
\text { da equipe. }\end{array}$ \\
\hline E10 & $\begin{array}{l}\text { "O mindset... de que é } \\
\text { possível a entrega de } \\
\text { modo rápido... O } \\
\text { acompanhamento em } \\
\text { fluxo de Kanban, a visão } \\
\text { colaborativa de } \\
\text { entrega... O processo de } \\
\text { cocriação". }\end{array}$ & $\begin{array}{l}\text { Mudança de mindset, } \\
\text { processos, colaboração e } \\
\text { cocriação. }\end{array}$ & & \\
\hline
\end{tabular}

(Continua) 


\begin{tabular}{|c|c|c|}
\hline & Unidade de Análise 3 & Resultados da transição (Continuação) \\
\hline & Questão & $\begin{array}{l}\text { Q21: O que mudou nos projetos depois da transição para o modelo ágil? O } \\
\text { que melhorou ou piorou (tempo, custo, qualidade)? }\end{array}$ \\
\hline & Subunidade & Benefícios da transição \\
\hline MP & \multicolumn{2}{|c|}{$\begin{array}{l}\text { A transição ágil trouxe muitos benefícios para as organizações, tanto em relação aos processos, incluindo } \\
\text { entregas mais rápidas e com maior qualidade, quanto em relação às pessoas, com maior integração e } \\
\text { colaboração entre as equipes. É importante que haja indicadores e ferramentas para medirem os } \\
\text { resultados antes e depois da transição e analisarem a evolução do modelo, bem como para identificarem } \\
\text { os pontos de melhoria. A autonomia do modelo ágil impacta positivamente a satisfação e o engajamento } \\
\text { das equipes, devido à participação de todos no processo. Foi identificado também um ponto de atenção } \\
\text { em relação ao custo de manutenção de equipes dedicadas, considerado ainda maior no modelo ágil, e que } \\
\text { deve ser levado em consideração no momento da decisão dos projetos a serem mantidos no modelo ágil } \\
\text { ou no tradicional. }\end{array}$} \\
\hline
\end{tabular}

Fonte: Quadro elaborado pela autora, com base nas entrevistas.

b) Objetivos atingidos

Três dos entrevistados (E2, E3 e E5) entenderam que os resultados da transição ainda não foram atingidos, mas que a empresa está no caminho certo. Outros três entrevistados (E1, E4 e E8) acreditaram que os objetivos foram atingidos e um deles (E6) que, inclusive, já foram superados (Quadro 10).

Quadro 10 - Análise da coleta de dados: Resultados da transição - Objetivos atingidos

\begin{tabular}{|c|c|c|c|c|}
\hline \multirow{4}{*}{ 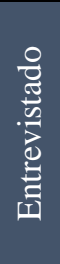 } & Unidade de Análise 3 & \multicolumn{3}{|l|}{ Resultados da transição } \\
\hline & Questão & \multicolumn{3}{|c|}{$\begin{array}{l}\text { Q26: Você acredita que os objetivos da transformação (motivadores) foram } \\
\text { atingidos com a transição ágil? }\end{array}$} \\
\hline & Subunidade & \multicolumn{3}{|l|}{ Objetivos atingidos } \\
\hline & Mensagem principal & $\begin{array}{c}\text { Interpretação da } \\
\text { mensagem principal }\end{array}$ & Mensagem associada & $\begin{array}{c}\text { Interpretação da } \\
\text { mensagem associada }\end{array}$ \\
\hline E1 & $\begin{array}{l}\text { "Acho que já foi } \\
\text { atingido e está no } \\
\text { caminho certo. O próprio } \\
\text { projeto piloto é um case } \\
\text { de sucesso". }\end{array}$ & $\begin{array}{l}\text { Objetivos atingidos. A } \\
\text { organização está no } \\
\text { caminho certo. }\end{array}$ & $\begin{array}{l}\text { "Não teve métricas e } \\
\text { indicadores da equipe de } \\
\text { transição ou da } \\
\text { consultoria para avaliar } \\
\text { se o resultado foi } \\
\text { positivo. Isso é uma } \\
\text { percepção minha de que } \\
\text { esse objetivo já foi } \\
\text { atingido". }\end{array}$ & $\begin{array}{l}\text { A percepção do } \\
\text { entrevistado foi de que } \\
\text { os objetivos foram } \\
\text { atingidos. }\end{array}$ \\
\hline E2 & $\begin{array}{l}\text { "Estamos no caminho... } \\
\text { os indicadores já } \\
\text { refletem isso". }\end{array}$ & $\begin{array}{l}\text { Objetivos parcialmente } \\
\text { atingidos. Os } \\
\text { indicadores comprovam } \\
\text { que a organização está } \\
\text { no caminho certo. }\end{array}$ & $\begin{array}{l}\text { "Para atingir aquele } \\
\text { objetivo final que nós } \\
\text { tínhamos, ainda tem } \\
\text { uma montanha que a } \\
\text { gente vai precisar } \\
\text { escalar... mas, estamos } \\
\text { no caminho e os } \\
\text { indicadores já traduzem } \\
\text { que estamos no caminho } \\
\text { certo". }\end{array}$ & $\begin{array}{l}\text { A entrevistada ressaltou } \\
\text { a importância de estar no } \\
\text { caminho certo, mas os } \\
\text { objetivos ainda estão } \\
\text { longe de serem atingidos } \\
\text { (talvez pela ambição do } \\
\text { objetivo). }\end{array}$ \\
\hline
\end{tabular}

(Continua) 


\begin{tabular}{|c|c|c|c|c|}
\hline \multirow{4}{*}{ 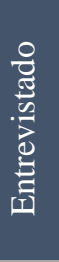 } & Unidade de Análise 3 & \multicolumn{3}{|c|}{ Resultados da transição (Continuação) } \\
\hline & Questão & \multicolumn{3}{|c|}{$\begin{array}{l}\text { Q26: Você acredita que os objetivos da transformação (motivadores) foram } \\
\text { atingidos com a transição ágil? }\end{array}$} \\
\hline & Subunidade & \multicolumn{3}{|l|}{ Objetivos atingidos } \\
\hline & Mensagem principal & $\begin{array}{l}\text { Interpretação da } \\
\text { mensagem principal }\end{array}$ & Mensagem associada & $\begin{array}{l}\text { Interpretação da } \\
\text { mensagem associada }\end{array}$ \\
\hline E3 & $\begin{array}{l}\text { "Estão sendo } \\
\text { atingidos... a gente } \\
\text { ainda está } \\
\text { engatinhando". }\end{array}$ & $\begin{array}{l}\text { Objetivos parcialmente } \\
\text { atingidos, porém, ainda } \\
\text { falta muito para cumpri- } \\
\text { los. }\end{array}$ & & \\
\hline $\mathbf{E 4}$ & $\begin{array}{l}\text { "Acho que no geral } \\
\text { sim... empresa } \\
\text { extremamente } \\
\text { competitiva. Ela tem } \\
\text { mais de } 100 \text { anos, e } \\
\text { continua se } \\
\text { reinventando". }\end{array}$ & $\begin{array}{l}\text { Objetivos atingidos. A } \\
\text { organização continua se } \\
\text { reinventando }\end{array}$ & & \\
\hline E5 & $\begin{array}{l}\text { "Não, ainda não... Está } \\
\text { [no caminho certo]". }\end{array}$ & $\begin{array}{l}\text { Objetivos parcialmente } \\
\text { atingidos. }\end{array}$ & $\begin{array}{l}\text { "Eu acho que os } \\
\text { objetivos são mais } \\
\text { nossos do que dos } \\
\text { executivos... O } \\
\text { tombamento das duas } \\
\text { primeiras esteiras e a } \\
\text { instituição do catálogo } \\
\text { de serviços do LACE... } \\
\text { criar a governança de } \\
\text { portfólio ágil das } \\
\text { esteiras no PMO". }\end{array}$ & $\begin{array}{l}\text { Os objetivos atingidos } \\
\text { referem-se à área do } \\
\text { LACE, tais como o } \\
\text { tombamento das squads } \\
\text { para o modelo ágil, } \\
\text { governança e catálogo } \\
\text { de serviços prestados } \\
\text { pela equipe. }\end{array}$ \\
\hline E6 & $\begin{array}{l}\text { "Foram até superados... } \\
\text { A gente já estava falando } \\
\text { de ágil escalado, que a } \\
\text { ideia era fazer depois de } \\
2 \text { anos... treinamentos } \\
\text { em Business Agility... } \\
\text { Inception... Design } \\
\text { Thinking... continuous } \\
\text { delivery... Coisas que } \\
\text { não estavam no radar } \\
\text { inicial foram se } \\
\text { encaixando ali no nosso } \\
\text { dia a dia". }\end{array}$ & $\begin{array}{l}\text { Objetivos superados, } \\
\text { pois a organização } \\
\text { realizou atividades que } \\
\text { não estavam previstas } \\
\text { no objetivo inicial da } \\
\text { transição. }\end{array}$ & & \\
\hline E8 & $\begin{array}{l}\text { "Para o que eles } \\
\text { queriam, eles } \\
\text { conseguiram". }\end{array}$ & $\begin{array}{l}\text { A percepção da } \\
\text { entrevistada foi de que } \\
\text { os objetivos foram } \\
\text { atingidos. }\end{array}$ & & \\
\hline MP & $\begin{array}{l}\text { Para que a organização co } \\
\text { claramente definidos ante } \\
\text { que os objetivos foram } \\
\text { transformação, que não n } \\
\text { mesma forma, o entrevist } \\
\text { de práticas de Ágil Escal } \\
\text { objetivos iniciais da tran } \\
\text { cumpridos referem-se prir } \\
\text { o mindset ágil. }\end{array}$ & $\begin{array}{l}\text { nsiga avaliar se os objetivo } \\
\text { s de a transição ter inicia } \\
\text { atingidos, essa visão r } \\
\text { ecessariamente era o de } \\
\text { ado que entende que os ob } \\
\text { ado, Inception e demais c } \\
\text { sição. Os entrevistados } \\
\text { ccipalmente à necessidade }\end{array}$ & $\begin{array}{l}\text { s foram atingidos, é neces } \\
\text { lo. Considerando-se os el } \\
\text { fere-se ao cumpriment } \\
\text { mplementar o modelo ás } \\
\text { jetivos foram superados, } \\
\text { onceitos de Business Agil } \\
\text { ue consideram que os o } \\
\text { de implantação nas dema }\end{array}$ & $\begin{array}{l}\text { ário que eles tenham sido } \\
\text { trevistados que acreditam } \\
\text { do objetivo inicial da } \\
\text { il na empresa inteira. Da } \\
\text { efere-se à implementação } \\
\text { ty, que estavam além dos } \\
\text { jetivos ainda não foram } \\
\text { s áreas e de mudança para }\end{array}$ \\
\hline
\end{tabular}

Fonte: Quadro elaborado pela autora, com base nas entrevistas. 
c) Realização de assessment posterior

Quanto à realização de um assessment depois da transição, há uma grande variação na forma como cada organização avaliou os resultados. Os entrevistados E1 e E5, ambos da Empresa A, informaram que houve divulgação apenas sobre o tombamento das equipes para o modelo ágil, por exemplo, em relação à quantidade de funcionários treinados e de equipes migradas. Dois outros entrevistados (E7 e E8) referiram-se à apresentação das entregas realizadas depois da transição para o modelo ágil, sem um comparativo com as entregas realizadas anteriormente. O entrevistado E9 comparou o processo de gestão de demandas antes e depois da transição e definiu indicadores de melhoria contínua. Dois dos entrevistados (E2 e E6) mencionaram também a avaliação do nível de maturidade da organização antes e depois da transição (Quadro 11).

Quadro 11 - Análise da coleta de dados: Resultados da transição - Realização de assessment posterior

\begin{tabular}{|c|c|c|c|c|}
\hline \multirow{4}{*}{ 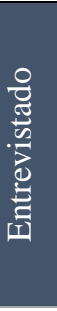 } & Unidade de Análise 3 & \multicolumn{3}{|l|}{ Resultados da Transição } \\
\hline & Questão & \multicolumn{3}{|c|}{$\begin{array}{l}\text { Q27: Houve assessment dos resultados obtidos depois da transição e } \\
\text { comparação com os resultados anteriores para medir o impacto com métricas } \\
\text { e indicadores? }\end{array}$} \\
\hline & Subunidade & \multicolumn{3}{|c|}{ Realização de assessment posterior } \\
\hline & Mensagem principal & $\begin{array}{c}\text { Interpretação da } \\
\text { mensagem principal }\end{array}$ & Mensagem associada & $\begin{array}{l}\text { Interpretação da } \\
\text { mensagem associada }\end{array}$ \\
\hline E1 & $\begin{array}{l}\text { "Tem uma } \\
\text { comunicação... com os } \\
\text { números do treinamento, } \\
\text { a quantidade de projetos } \\
\text { piloto, tombamento por } \\
\text { linha de negócio". }\end{array}$ & $\begin{array}{l}\text { Os indicadores refletem } \\
\text { o resultado da transição } \\
\text { e não o das entregas. }\end{array}$ & & \\
\hline E2 & $\begin{array}{l}\text { "Estamos melhorando } \\
\text { nosso indicador de } \\
\text { velocidade... squads } \\
\text { com um nível de } \\
\text { maturidade melhor... } \\
\text { processo de lean... } \\
\text { processo de melhoria } \\
\text { contínua dentro das } \\
\text { squads". }\end{array}$ & $\begin{array}{l}\text { A organização possui } \\
\text { indicadores para análise } \\
\text { das entregas e da } \\
\text { melhoria contínua. }\end{array}$ & & \\
\hline $\mathbf{E 3}$ & "Eu nunca vi". & $\begin{array}{l}\text { A entrevistada } \\
\text { desconhece se existem } \\
\text { indicadores. }\end{array}$ & $\begin{array}{l}\text { "Talvez tenham nesses } \\
\text { fóruns do Digital, mas o } \\
\text { povo não cascateia". }\end{array}$ & $\begin{array}{l}\text { Não houve } \\
\text { cascateamento das } \\
\text { informações para todos } \\
\text { os níveis da organização. }\end{array}$ \\
\hline
\end{tabular}




\begin{tabular}{|c|c|c|c|c|}
\hline \multirow{4}{*}{ 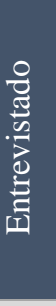 } & Unidade de Análise 3 & \multicolumn{3}{|c|}{ Resultados da Transição (Continuação) } \\
\hline & Questão & \multicolumn{3}{|c|}{$\begin{array}{l}\text { Q27: Houve assessment dos resultados obtidos depois da transição e } \\
\text { comparação com os resultados anteriores para medir o impacto com métricas } \\
\text { e indicadores? }\end{array}$} \\
\hline & Subunidade & \multicolumn{3}{|c|}{ Realização de assessment posterior } \\
\hline & Mensagem principal & $\begin{array}{l}\text { Interpretação da } \\
\text { mensagem principal }\end{array}$ & Mensagem associada & $\begin{array}{l}\text { Interpretação da } \\
\text { mensagem associada }\end{array}$ \\
\hline E4 & $\begin{array}{l}\text { "Mapeamento de } \\
\text { processos, identificação } \\
\text { de lead time, cycle time e } \\
\text { throughput... A } \\
\text { Empresa C tinha base } \\
\text { Lean". }\end{array}$ & $\begin{array}{l}\text { A organização aplicou } \\
\text { indicadores Lean para } \\
\text { melhoria de processos. }\end{array}$ & $\begin{array}{l}\text { "A gente foi } \\
\text { identificando onde eram } \\
\text { os gargalos... Eu não } \\
\text { consigo melhorar se isso } \\
\text { não for eliminado, aí a } \\
\text { empresa viu que } \\
\text { precisava fazer essa } \\
\text { mudança de forma } \\
\text { global". }\end{array}$ & $\begin{array}{l}\text { Houve melhoria de } \\
\text { processos de forma } \\
\text { global, evidenciando os } \\
\text { gargalos. }\end{array}$ \\
\hline E5 & $\begin{array}{l}\text { "Quantas pessoas } \\
\text { envolvidas, quantas } \\
\text { pessoas foram treinadas, } \\
\text { quais os serviços a gente } \\
\text { disponibilizou, eventos } \\
\text { que a gente organizou". }\end{array}$ & $\begin{array}{l}\text { Os indicadores refletem } \\
\text { o resultado da transição } \\
\text { e não o das entregas. }\end{array}$ & $\begin{array}{l}\text { "Esse ano a gente tem } \\
\text { que urgentemente } \\
\text { evoluir nos } \\
\text { indicadores". }\end{array}$ & $\begin{array}{l}\text { Necessidade de melhorar } \\
\text { os indicadores da } \\
\text { organização. }\end{array}$ \\
\hline E6 & $\begin{array}{l}\text { "No início, com } \\
\text { maturidade zero, a visão } \\
\text { era das práticas, negócio } \\
\text { e melhoria contínua... } \\
\text { Até chegar no nível } 4, \\
\text { que é de Business } \\
\text { Agility. Então a gente } \\
\text { saiu do nível zero para 1, } \\
\text { em } 6 \text { meses... todas as } \\
\text { squads rodando com as } \\
\text { práticas, cerimônias... A } \\
\text { meta era chegar, em um } \\
\text { ano, ao nível } 1.5 \text { de } \\
\text { maturidade". }\end{array}$ & $\begin{array}{l}\text { Os indicadores referem- } \\
\text { se ao nível de } \\
\text { maturidade da aplicação } \\
\text { das práticas ágeis. }\end{array}$ & & \\
\hline E7 & $\begin{array}{l}\text { "Não teve o } \\
\text { comparativo, só mostrou } \\
\text { o que estava sendo } \\
\text { entregue". }\end{array}$ & $\begin{array}{l}\text { Foram apresentadas } \\
\text { apenas as entregas e não } \\
\text { um indicador de } \\
\text { evolução. }\end{array}$ & & \\
\hline E8 & $\begin{array}{l}\text { "Não, não tem } \\
\text { indicador... Teve uma } \\
\text { apresentação... e a gente } \\
\text { fez muita entrega no ano } \\
\text { passado... foi bem } \\
\text { importante". }\end{array}$ & $\begin{array}{l}\text { Foram apresentadas } \\
\text { apenas as entregas e não } \\
\text { um indicador de } \\
\text { evolução. }\end{array}$ & & \\
\hline E9 & $\begin{array}{l}\text { "Apresentação de como } \\
\text { era antes e como está } \\
\text { agora... a gestão de } \\
\text { demandas passa a ser } \\
\text { dessa nova forma". }\end{array}$ & $\begin{array}{l}\text { Houve uma } \\
\text { apresentação } \\
\text { comparando o processo } \\
\text { de gestão de demandas } \\
\text { antes e depois da } \\
\text { transição ágil. }\end{array}$ & & \\
\hline
\end{tabular}

(Continua) 


\begin{tabular}{|c|c|c|}
\hline \multirow{3}{*}{ 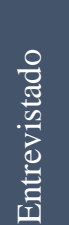 } & Unidade de Análise 3 & Resultados da Transição (Continuação) \\
\hline & Questão & $\begin{array}{l}\text { Q27: Houve assessment dos resultados obtidos depois da transição e } \\
\text { comparação com os resultados anteriores para medir o impacto com métricas } \\
\text { e indicadores? }\end{array}$ \\
\hline & Subunidade & Realização de assessment posterior \\
\hline MP & \multicolumn{2}{|c|}{$\begin{array}{l}\text { Houve uma grande variação nas métricas utilizadas para definir o sucesso da transição: algumas } \\
\text { organizações mediram o resultado da migração das equipes, enquanto outras analisaram os indicadores } \\
\text { de projetos, compararam o processo anterior ao atual, ou ainda compararam o nível de maturidade ági } \\
\text { das equipes. Apenas alguns dos entrevistados relataram que as métricas foram utilizadas no processo de } \\
\text { melhoria contínua, para definição dos temas em que a organização deveria atuar. Outros descreveram } \\
\text { que a organização ainda carecia da definição de métricas para conseguir avaliar os resultados da } \\
\text { transição. }\end{array}$} \\
\hline
\end{tabular}

Fonte: Quadro elaborado pela autora, com base nas entrevistas.

d) Inovação

Quanto à inovação, cinco dos entrevistados (E1, E4, E6, E7 e E9) acreditavam que a organização havia se tornado mais inovadora depois da implantação do modelo ágil, na maioria das vezes impulsionada pela aplicação de sessões de Inception ou de Design Thinking com os clientes. Dois dos entrevistados (E5 e E10) acreditavam que a organização estava mais inovadora, porém não necessariamente devido à implantação do modelo ágil. O entrevistado E2 relatou a demora da organização no reposicionamento no mercado e na implementação do modelo ágil como fatores que facilitaram a ascensão das startups, que já nasceram no modelo ágil, oferecendo produtos e serviços inovadores (Quadro 12).

Quadro 12 - Análise da coleta de dados: Resultados da transição - Inovação

\begin{tabular}{|c|c|c|c|c|}
\hline & Unidade de Análise 3 & \multicolumn{3}{|l|}{ Resultados da Transição } \\
\hline 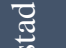 & Questão & \multicolumn{3}{|c|}{ Q24: A empresa tornou-se mais inovadora depois da transformação ágil? } \\
\hline 2 & Subunidade & \multicolumn{3}{|l|}{ Inovação } \\
\hline 표 & Mensagem principal & $\begin{array}{c}\text { Interpretação da } \\
\text { mensagem principal }\end{array}$ & Mensagem associada & $\begin{array}{c}\text { Interpretação da } \\
\text { mensagem associada }\end{array}$ \\
\hline E1 & $\begin{array}{l}\text { "Sim, está mais apta } \\
\text { para inovação, mas } \\
\text { ainda está nos passos } \\
\text { iniciais". }\end{array}$ & $\begin{array}{l}\text { A organização tornou- } \\
\text { se mais inovadora, } \\
\text { porém ainda está nos } \\
\text { passos iniciais. }\end{array}$ & & \\
\hline
\end{tabular}

(Continua) 


\begin{tabular}{|c|c|c|c|c|}
\hline \multirow{4}{*}{ 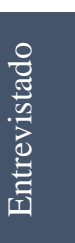 } & \multirow{3}{*}{$\begin{array}{l}\text { Unidade de Análise } 3 \\
\text { Questão } \\
\text { Subunidade }\end{array}$} & \multicolumn{3}{|c|}{ Resultados da Transição (Continuação) } \\
\hline & & \multicolumn{3}{|c|}{ Q24: A empresa tornou-se mais inovadora depois da transformação ágil? } \\
\hline & & \multicolumn{3}{|l|}{ Inovação } \\
\hline & Mensagem principal & $\begin{array}{l}\text { Interpretação da } \\
\text { mensagem principal }\end{array}$ & Mensagem associada & $\begin{array}{l}\text { Interpretação da } \\
\text { mensagem associada }\end{array}$ \\
\hline $\mathbf{E 2}$ & $\begin{array}{l}\text { “A gente ainda está } \\
\text { muito na retaguarda. } \\
\text { Mas, foi efeito de } \\
\text { muitos anos de } \\
\text { procrastinação... Vai } \\
\text { demorar para a gente ser } \\
\text { novamente uma marca } \\
\text { protagonista nesse } \\
\text { mercado... Mas, } \\
\text { estamos caminhando... } \\
\text { Não estamos parados } \\
\text { mais". }\end{array}$ & $\begin{array}{l}\text { Está no caminho, } \\
\text { porém, ainda está nos } \\
\text { passos iniciais devido à } \\
\text { decisão tardia de } \\
\text { migrar seus processos. }\end{array}$ & $\begin{array}{l}\text { “A Empresa B sempre } \\
\text { esteve num pedestal... } \\
\text { 'Eu não vou mudar meu } \\
\text { preço porque eu sou uma } \\
\text { marca diferenciada, uma } \\
\text { marca premium"”. }\end{array}$ & $\begin{array}{l}\text { Foi necessária uma } \\
\text { mudança da mentalidade } \\
\text { da organização para que } \\
\text { decidisse se transformar. }\end{array}$ \\
\hline $\mathbf{E 3}$ & "Não". & $\begin{array}{l}\text { A organização não se } \\
\text { tornou mais inovadora } \\
\text { depois da } \\
\text { transformação ágil. }\end{array}$ & & \\
\hline $\mathbf{E 4}$ & $\begin{array}{l}\text { “Acho que sim.... Junto } \\
\text { com a agilidade, a } \\
\text { Empresa C começou a } \\
\text { aplicar algumas práticas } \\
\text { de Design Thinking... a } \\
\text { gente trazia o cliente } \\
\text { para entender as dores } \\
\text { deles e para fazer } \\
\text { ideação e pensar em } \\
\text { soluções”. }\end{array}$ & $\begin{array}{l}\text { A organização tornou- } \\
\text { se mais inovadora ao } \\
\text { aplicar práticas de } \\
\text { Design Thinking com } \\
\text { os clientes. }\end{array}$ & & \\
\hline $\mathbf{E 5}$ & $\begin{array}{l}\text { "Eu acho que não por } \\
\text { causa da transformação } \\
\text { ágil. Acho que pelo } \\
\text { próprio movimento do } \\
\text { mercado. A agilidade } \\
\text { está ajudando a entregar } \\
\text { esses produtos, mas não } \\
\text { é por isso que a gente } \\
\text { decidiu fazer novos } \\
\text { produtos". }\end{array}$ & $\begin{array}{l}\text { A organização está } \\
\text { mais inovadora, mas } \\
\text { não devido à } \\
\text { transformação ágil. }\end{array}$ & & \\
\hline E6 & $\begin{array}{l}\text { "Com certeza... sessões } \\
\text { de Design Thinking com } \\
\text { os clientes... para fazer } \\
\text { um modelo de ideação... } \\
\text { inovação não } \\
\text { necessariamente } \\
\text { tecnológica... mais do } \\
\text { ponto de vista de } \\
\text { produto". }\end{array}$ & $\begin{array}{l}\text { A organização tornou- } \\
\text { se mais inovadora ao } \\
\text { aplicar práticas de } \\
\text { Design Thinking com } \\
\text { os clientes. }\end{array}$ & & \\
\hline E7 & $\begin{array}{l}\text { "Sim, porque a Empresa } \\
\text { E é muito preocupada } \\
\text { em acompanhar o } \\
\text { mercado... Eles foram } \\
\text { se reinventando". }\end{array}$ & $\begin{array}{l}\text { A organização tornou- } \\
\text { se mais inovadora e } \\
\text { está sempre buscando } \\
\text { novas tecnologias. }\end{array}$ & & \\
\hline
\end{tabular}

(Continua) 


\begin{tabular}{|c|c|c|c|c|}
\hline & Unidade de Análise 3 & \multicolumn{3}{|c|}{ Resultados da Transição (Continuação) } \\
\hline & Questão & \multicolumn{3}{|c|}{ Q24: A empresa tornou-se mais inovadora depois da transformação ágil? } \\
\hline & Subunidade & \multicolumn{3}{|l|}{ Inovação } \\
\hline$\underset{\text { [I }}{\vec{E}}$ & Mensagem principal & $\begin{array}{l}\text { Interpretação da } \\
\text { mensagem principal }\end{array}$ & Mensagem associada & $\begin{array}{c}\text { Interpretação da } \\
\text { mensagem associada }\end{array}$ \\
\hline E8 & $\begin{array}{l}\text { "O ágil está na camada } \\
\text { do 'fazer', o 'criar' a } \\
\text { gente ainda não usa. O } \\
\text { que eu entendo que } \\
\text { poderia trazer ganho é o } \\
\text { Design Thinking, as } \\
\text { Inceptions". }\end{array}$ & $\begin{array}{l}\text { A organização poderia } \\
\text { se tornar mais } \\
\text { inovadora se aplicasse } \\
\text { as práticas de Design } \\
\text { Thinking e Inception. }\end{array}$ & & \\
\hline E9 & $\begin{array}{l}\text { "A gente faz muita } \\
\text { reunião de Inception... } \\
\text { de Design Thinking... } \\
\text { UX... para fazer } \\
\text { pesquisa com cliente... } \\
\text { área de benchmarking... } \\
\text { comitê de inovação, } \\
\text { então tudo isso } \\
\text { contribuiu muito para a } \\
\text { gente melhorar a } \\
\text { inovação na empresa". }\end{array}$ & $\begin{array}{l}\text { A organização tornou- } \\
\text { se mais inovadora ao } \\
\text { aplicar práticas de } \\
\text { Design Thinking, } \\
\text { Inception e UX com os } \\
\text { clientes. Além disso, } \\
\text { criou uma área de } \\
\text { benchmarking e o } \\
\text { comitê de inovação. }\end{array}$ & & \\
\hline E10 & $\begin{array}{l}\text { "Eu acho que eles estão } \\
\text { querendo entregar coisas } \\
\text { novas. A forma, que } \\
\text { seria a agilidade, é que } \\
\text { de repente não está [no } \\
\text { caminho]". }\end{array}$ & $\begin{array}{l}\text { A organização está } \\
\text { mais inovadora, mas } \\
\text { não devido à } \\
\text { transformação ágil. }\end{array}$ & $\begin{array}{l}\text { "Eles não perceberam o } \\
\text { que é o MVP, o que é } \\
\text { entregar por } \\
\text { experimentação... } \\
\text { características da } \\
\text { inovação... que não } \\
\text { foram absorvidas. 'Eu } \\
\text { quero conseguir mudar a } \\
\text { qualquer momento } \\
\text { porque eu sou criativo'... } \\
\text { E aí tem muita perda de } \\
\text { foco". }\end{array}$ & $\begin{array}{l}\text { A organização ainda não } \\
\text { possui o mindset ágil } \\
\text { para a inovação, } \\
\text { considerando conceitos } \\
\text { de experimentação e de } \\
\text { MVP. A mudança de } \\
\text { prioridade gera perda de } \\
\text { foco da equipe no } \\
\text { desenvolvimento dos } \\
\text { projetos. }\end{array}$ \\
\hline MP & \multicolumn{4}{|c|}{$\begin{array}{l}\text { O modelo ágil possibilitou a implementação de produtos inovadores de forma mais rápida, porém, não } \\
\text { necessariamente fez com que a organização se tornasse mais inovadora. O que realmente impactou na } \\
\text { inovação foram as práticas como as de Inception, Design Thinking e UX (User Experience), focadas no } \\
\text { cliente e que permitem feedbacks imediatos. O conceito de experimentação do modelo ágil também foi } \\
\text { um fator essencial para a inovação, pois permitiu que produtos e serviços fossem lançados de forma } \\
\text { mais rápida para a obtenção do feedback do cliente, antes do desenvolvimento de todas as } \\
\text { funcionalidades. }\end{array}$} \\
\hline
\end{tabular}

Fonte: Quadro elaborado pela autora, com base nas entrevistas.

e) Pendências da transição

Considerando-se a percepção dos entrevistados quanto ao que falta à organização para que ela se torne mais ágil, as respostas variaram bastante. Porém, em todas nota-se o desejo de ir além da simples implementação das práticas ágeis. Dois dos entrevistados (E1 e E2) mencionaram a necessidade de implementar o modelo ágil nas demais áreas da organização. Quatro dos entrevistados (E4, E6, E7 e E9) citaram a necessidade de elevar o nível de 
maturidade das equipes, através da implantação do Ágil Escalado em toda a cadeia de valor e da integração do modelo operacional com os objetivos estratégicos (Quadro 13).

Quadro 13 - Análise da coleta de dados: Resultados da transição - Pendências da transição

\begin{tabular}{|c|c|c|c|c|}
\hline \multirow{4}{*}{ 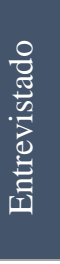 } & Unidade de Análise 3 & \multicolumn{3}{|l|}{ Resultados da transição } \\
\hline & Questão & \multicolumn{3}{|c|}{$\begin{array}{l}\text { Q29: O que você acredita que ainda falte mudar para que a empresa seja mais } \\
\text { ágil? }\end{array}$} \\
\hline & Subunidade & \multicolumn{3}{|l|}{ Pendências da transição } \\
\hline & Mensagem principal & $\begin{array}{l}\text { Interpretação da } \\
\text { mensagem principal }\end{array}$ & Mensagem associada & $\begin{array}{l}\text { Interpretação da } \\
\text { mensagem associada }\end{array}$ \\
\hline E1 & $\begin{array}{l}\text { "Falta implementar nas } \\
\text { áreas cross, RH, jurídico } \\
\text { e infra". }\end{array}$ & $\begin{array}{l}\text { Implantar o modelo ágil } \\
\text { nas demais áreas que } \\
\text { impactam projetos. }\end{array}$ & & \\
\hline $\mathbf{E} 2$ & $\begin{array}{l}\text { "Eu acho que a cultura } \\
\text { tem que mudar, as } \\
\text { pessoas têm que } \\
\text { mudar... Precisa abarcar } \\
\text { a empresa como um } \\
\text { todo, por exemplo, } \\
\text { processos em RH, } \\
\text { processos no jurídico, } \\
\text { que são áreas que... } \\
\text { impactam projetos... e } \\
\text { priorização". }\end{array}$ & $\begin{array}{l}\text { Implantar o modelo ágil } \\
\text { nas demais áreas que } \\
\text { impactam projetos e } \\
\text { mudar a cultura. }\end{array}$ & & \\
\hline $\mathbf{E 3}$ & $\begin{array}{l}\text { "É mais a gente se } \\
\text { estruturar... A gente é } \\
\text { desorganizado na hora } \\
\text { de falar o que a gente vai } \\
\text { atacar... Acho que nem o } \\
\text { básico... a gente } \\
\text { consegue fazer". }\end{array}$ & $\begin{array}{l}\text { Focar na priorização dos } \\
\text { projetos. }\end{array}$ & $\begin{array}{l}\text { A gente leva milhares de } \\
\text { riscos... mas eles } \\
\text { falam... "vamos em } \\
\text { frente... as decisões são } \\
\text { top-down... Então é isso } \\
\text { que eu acho que não é } \\
\text { ágil, que falta o conceito } \\
\text { do mínimo". }\end{array}$ & $\begin{array}{l}\text { Ainda há uma hierarquia } \\
\text { muito forte na } \\
\text { organização que impacta } \\
\text { a priorização dos } \\
\text { projetos. }\end{array}$ \\
\hline E4 & $\begin{array}{l}\text { "Atuar mais no nível } \\
\text { estratégico... por ser } \\
\text { uma empresa global, os } \\
\text { diretores estão nos EUA, } \\
\text { então a estratégia era } \\
\text { feita lá". }\end{array}$ & $\begin{array}{l}\text { Atuar no nível } \\
\text { estratégico. }\end{array}$ & & \\
\hline $\mathbf{E 5}$ & $\begin{array}{l}\text { "Falta... o RH encabeçar } \\
\text { a mudança de alguns } \\
\text { cargos executivos que } \\
\text { bem ou mal ainda são } \\
\text { um câncer para a } \\
\text { empresa... O RH não } \\
\text { pode ser político, ele } \\
\text { tem que comprar briga. } \\
\text { E não é comprar briga } \\
\text { para vir de bermuda. } \\
\text { Não adianta dar fruta } \\
\text { todo dia e não ter } \\
\text { qualidade de vida". }\end{array}$ & $\begin{array}{l}\text { Mudar a cultura da } \\
\text { organização, } \\
\text { principalmente no nível } \\
\text { executivo. }\end{array}$ & & \\
\hline
\end{tabular}




\begin{tabular}{|c|c|c|c|c|}
\hline \multirow{4}{*}{ 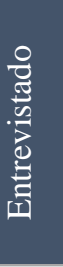 } & Unidade de Análise 3 & \multicolumn{3}{|c|}{ Resultados da transição (Continuação) } \\
\hline & Questão & \multicolumn{3}{|c|}{$\begin{array}{l}\text { Q29: O que você acredita que ainda falte mudar para que a empresa seja mais } \\
\text { ágil? }\end{array}$} \\
\hline & Subunidade & \multicolumn{3}{|l|}{ Pendências da transição } \\
\hline & Mensagem principal & $\begin{array}{l}\text { Interpretação da } \\
\text { mensagem principal }\end{array}$ & Mensagem associada & $\begin{array}{l}\text { Interpretação da } \\
\text { mensagem associada }\end{array}$ \\
\hline E6 & $\begin{array}{l}\text { "Quando você pensa em } \\
\text { orçamento, quando você } \\
\text { pensa em meta, ainda é o } \\
\text { modelo tradicional... } \\
\text { ainda não tem uma } \\
\text { estrutura de value } \\
\text { stream... Ainda está } \\
\text { muito orçamentado por } \\
\text { projeto, vamos dizer } \\
\text { assim, ainda falta subir o } \\
\text { nível dessa agilidade". }\end{array}$ & $\begin{array}{l}\text { Atuar no nível } \\
\text { estratégico e aumentar o } \\
\text { nível de maturidade ágil. }\end{array}$ & $\begin{array}{l}\text { "Mas não era a meta do } \\
\text { projeto. A meta do } \\
\text { projeto era botar para } \\
\text { rodar... Eu não sei se } \\
\text { necessariamente é esse o } \\
\text { objetivo". }\end{array}$ & $\begin{array}{l}\text { O nível de Business } \\
\text { Agility não era uma } \\
\text { meta do projeto de } \\
\text { transição. }\end{array}$ \\
\hline E7 & $\begin{array}{l}\text { "Amadurecer o ágil } \\
\text { escalado... O pessoal } \\
\text { não entendia ainda o que } \\
\text { era release muito bem... } \\
\text { talvez migrar a própria } \\
\text { área de negócio". }\end{array}$ & $\begin{array}{l}\text { Aumentar o nível de } \\
\text { maturidade ágil. }\end{array}$ & & \\
\hline E8 & "A parte Discovery". & $\begin{array}{l}\text { Atuar nos processos de } \\
\text { Discovery (por exemplo, } \\
\text { Inception e Design } \\
\text { Thinking). }\end{array}$ & & \\
\hline E9 & $\begin{array}{l}\text { "Melhorar a maturidade } \\
\text { dos times ágeis... Fazer } \\
\text { direito uma cerimônia. } \\
\text { Saber priorizar... Olhar } \\
\text { o } O K R \text { antes de sair } \\
\text { desenvolvendo. } \\
\text { Aprender a fazer } \\
\text { pesquisa com o cliente } \\
\text { antes de desenvolver". }\end{array}$ & $\begin{array}{l}\text { Aumentar o nível de } \\
\text { maturidade ágil e atuar } \\
\text { no nível estratégico. }\end{array}$ & & \\
\hline MP & \multicolumn{4}{|c|}{$\begin{array}{l}\text { A implantação das práticas ágeis apenas na área de tecnologia não foi suficiente para realizar a } \\
\text { transformação ágil nas organizações. Por este motivo, alguns dos entrevistados consideraram que a } \\
\text { transição deveria ser realizada também nas demais áreas, focando na mudança de cultura da organização. } \\
\text { Para os casos em que o modelo e a cultura ágil já estavam sedimentados na organização, pode-se } \\
\text { aumentar o nível de maturidade, incluindo práticas de Discovery (como por exemplo, Inception e Design } \\
\text { Thinking) e atuando em um nível mais estratégico (com a implementação de OKR's e de Business } \\
\text { Agility). }\end{array}$} \\
\hline
\end{tabular}

Fonte: Quadro elaborado pela autora, com base nas entrevistas.

\subsubsection{Processos organizacionais - coleta de dados primários (UA 4)}

A adequação dos processos organizacionais ao novo modelo requer cuidado para que sejam aplicados apenas os processos ágeis que façam sentido para a cultura da organização e sejam mantidos os tradicionais que funcionem bem. A segregação entre os projetos desenvolvidos em cada modelo depende da estratégia da organização, podendo ser por unidade de negócio, por tipo de produto ou por característica do projeto. Neste último caso, 
conforme mencionado pelos entrevistados E2, E6 e E9, não há na organização o objetivo de migrá-los para o modelo ágil. Alguns exemplos citados pelos entrevistados foram projetos regulatórios ou que possuíam um processo muito bem definido, com escopo e prazo determinados. A organização deve avaliar os casos pontualmente para identificar quais tipos de projetos serão executados de forma ágil e quais os que serão mantidos no modelo tradicional (Quadro 14).

Quadro 14 - Análise da coleta de dados: Processos organizacionais

\begin{tabular}{|c|c|c|c|c|}
\hline \multirow{3}{*}{ 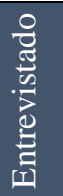 } & \multirow{3}{*}{$\begin{array}{l}\text { Unidade de Análise } 4 \\
\text { Questão } \\
\text { Mensagem principal }\end{array}$} & \multirow{2}{*}{\multicolumn{3}{|c|}{$\begin{array}{l}\text { Processos Organizacionais } \\
\text { Q7: A empresa ainda implementa projetos no modelo tradicional? }\end{array}$}} \\
\hline & & & & \\
\hline & & $\begin{array}{l}\text { Interpretação da } \\
\text { mensagem principal }\end{array}$ & Mensagem associada & $\begin{array}{c}\text { Interpretação da } \\
\text { mensagem associada }\end{array}$ \\
\hline $\mathbf{E 2}$ & $\begin{array}{l}\text { "É um projeto grande, } \\
\text { de visibilidade. É um } \\
\text { projeto que tem uma } \\
\text { pressão por ser um } \\
\text { projeto mandatório. É } \\
\text { um projeto que vai } \\
\text { mudar muito os } \\
\text { processos da empresa". }\end{array}$ & $\begin{array}{l}\text { A organização ainda } \\
\text { mantém a estrutura } \\
\text { tradicional para projetos } \\
\text { regulatórios, com o } \\
\text { papel de Gerente de } \\
\text { Projetos. }\end{array}$ & & \\
\hline E6 & $\begin{array}{l}\text { " Começou a vir aquela } \\
\text { pressão de 'tudo tem } \\
\text { que ser ágil'... Uma } \\
\text { normativa... que a } \\
\text { empresa já tem o know- } \\
\text { how... tem data limite } \\
\text { de normativa, tem } \\
\text { escopo dado". }\end{array}$ & $\begin{array}{l}\text { A organização ainda } \\
\text { mantém a estrutura } \\
\text { tradicional para projetos } \\
\text { regulatórios, com o } \\
\text { papel de Gerente de } \\
\text { Projetos. }\end{array}$ & $\begin{array}{l}\text { "Tem projetos que por } \\
\text { característica não fazia } \\
\text { sentido você criar uma } \\
\text { estrutura... Os clientes } \\
\text { querem cronograma". }\end{array}$ & $\begin{array}{l}\text { A criação da estrutura } \\
\text { ágil é citada como um } \\
\text { componente custoso para } \\
\text { a organização, pois } \\
\text { requer equipe dedicada. } \\
\text { Ainda há grande pressão } \\
\text { dos clientes para a } \\
\text { definição de datas de } \\
\text { entrega e envio do } \\
\text { cronograma. }\end{array}$ \\
\hline E9 & $\begin{array}{l}\text { "No fundo, não é tudo } \\
\text { que funciona } 100 \% \text { no } \\
\text { modelo ágil". }\end{array}$ & $\begin{array}{l}\text { A organização ainda } \\
\text { mantém a estrutura } \\
\text { tradicional para alguns } \\
\text { projetos. }\end{array}$ & $\begin{array}{l}\text { "Não faz sentido eu } \\
\text { colocar um 'produteiro' } \\
\text { para desenvolver um } \\
\text { robô". }\end{array}$ & $\begin{array}{l}\text { A criação da estrutura } \\
\text { ágil é citada como um } \\
\text { componente custoso para } \\
\text { a organização, pois } \\
\text { requer equipe dedicada. }\end{array}$ \\
\hline MP & \multicolumn{4}{|c|}{$\begin{array}{l}\text { Houve percepção por parte dos entrevistados de que nem todos os projetos adaptaram-se ao modelo ágil. } \\
\text { Por exemplo, projetos que possuíam requisitos bem definidos, para os quais a organização já possuía } \\
\text { know-how de como executá-los ou projetos com necessidade de informar o prazo de entrega ao mercado. } \\
\text { É importante que a organização defina quais tipos de projetos serão realizados de forma ágil e quais } \\
\text { serão mantidos no modelo tradicional, de acordo com sua característica. Esta definição deve considerar o } \\
\text { custo dos projetos, que pode ser mais baixo no modelo tradicional. }\end{array}$} \\
\hline
\end{tabular}

Fonte: Quadro elaborado pela autora, com base nas entrevistas.

4.2.1.5 Estimativas - coleta de dados primários (UA 5)

A recomendação da literatura é que a estimativa de custo e de prazo dos projetos desenvolvidos no modelo ágil seja realizada em alto nível, antes do início do projeto, para a aprovação do investimento inicial, e que, a cada detalhamento, seja revisada de acordo com o 
andamento do projeto. Porém, observa-se que muitos executivos, principalmente nos níveis hierárquicos mais altos, ainda não se sentem confortáveis em não conhecer o prazo final e nem o custo total do projeto antes de sua execução. Sendo assim, diversas organizações ainda mantêm as estimativas no modelo tradicional, incluindo as práticas ágeis apenas durante o desenvolvimento e mantendo a necessidade de aprovação de Change Requests pelos executivos, caso haja desvios de prazo ou de custo do projeto.

a) Necessidade de estimativas

Os entrevistados E1, E5 e E10 informaram que ainda existia na organização a necessidade da aprovação do Business Case, antes do início do projeto, incluindo a estimativa de custo e de prazo. Além disso, o entrevistado E10 ressaltou também que, para os projetos ágeis, a estimativa não é realizada pela equipe de desenvolvimento, podendo gerar divergências entre a estimativa e a execução. No ponto de vista do entrevistado E8, a equipe costuma informar apenas a estimativa de prazo, incluindo a quantidade de sprints necessárias para o desenvolvimento do projeto e cabe à área de Recursos Humanos o controle do custo do projeto.

Os entrevistados E2, E3, E4 e E6 informaram que era feita uma estimativa em alto nível no início do projeto, que era detalhada à medida que o projeto ia sendo executado. As estimativas geralmente levaram em consideração a classificação de tamanho do projeto (por exemplo, Pequeno, Médio ou Grande) e, posteriormente, o desvio em relação à estimativa inicial era mensurado. Apenas os entrevistados E7 e E9 informaram que suas organizações não trabalhavam com um prazo definido para a entrega do projeto. O entrevistado E9 informou que a organização solicitava um prazo apenas quando o projeto era estratégico. Caso contrário, trabalhava apenas com resultados, no modelo de ágil escalado (nível de maturidade alto) (Quadro 15). 
Quadro 15 - Análise da coleta de dados: Estimativas - Necessidade de estimativas

\begin{tabular}{|c|c|c|c|c|}
\hline \multirow{4}{*}{ 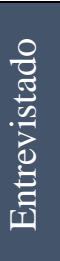 } & Análise 5 & \multicolumn{3}{|l|}{ Estimativas } \\
\hline & Questão & \multicolumn{3}{|c|}{$\begin{array}{l}\text { Q13: Como é feita a estimativa de custo e de prazo do projeto? A organização } \\
\text { trabalha com o conceito de MVP? }\end{array}$} \\
\hline & Subunidade & \multicolumn{3}{|l|}{ Necessidade de estimativas } \\
\hline & Mensagem principal & $\begin{array}{l}\text { Interpretação da } \\
\text { mensagem principal }\end{array}$ & Mensagem associada & $\begin{array}{c}\text { Interpretação da } \\
\text { mensagem associada }\end{array}$ \\
\hline E1 & $\begin{array}{l}\text { "A estimativa ainda tem, } \\
\text { mesmo com o ágil, na } \\
\text { fase de aprovação do } \\
\text { projeto". }\end{array}$ & $\begin{array}{l}\text { A organização trabalha } \\
\text { com a aprovação do } \\
\text { Business Case antes do } \\
\text { início do projeto, } \\
\text { incluindo estimativa de } \\
\text { custo e de prazo. }\end{array}$ & $\begin{array}{l}\text { "Se houve necessidade } \\
\text { de orçamento adicional, } \\
\text { precisa de aprovação... } \\
\text { A gestão não vê com } \\
\text { bons olhos quando o } \\
\text { custo adicional foi } \\
\text { inesperado". }\end{array}$ & $\begin{array}{l}\text { Ainda há a necessidade } \\
\text { de aprovação de Change } \\
\text { Requests, caso haja } \\
\text { desvio de custo e de } \\
\text { prazo. }\end{array}$ \\
\hline E2 & $\begin{array}{l}\text { "Quando eu começo um } \\
\text { projeto que é ágil, eu } \\
\text { começo com um } \\
\text { valor...O projeto XPTO }{ }^{1} \\
\text { vai ser em ágil e ele tem } \\
1.2 \text { milhão... Quais são } \\
\text { os skills que eu preciso? } \\
\text { Isso vai dar } 100 \text { mil por } \\
\text { mês... então eu sei que eu } \\
\text { tenho um fôlego de } \\
\text { alocação de } 12 \text { meses". }\end{array}$ & $\begin{array}{l}\text { A organização trabalha } \\
\text { com uma estimativa em } \\
\text { alto nível no início do } \\
\text { projeto, incluindo as } \\
\text { equipes } \\
\text { multidisciplinares. }\end{array}$ & $\begin{array}{l}\text { "O que eu vou fazer } \\
\text { nesses } 12 \text { meses? Eu } \\
\text { vou fazer aquilo que o } \\
\text { meu PO e BO priorizam } \\
\text { dentro das sprints e eu } \\
\text { vou trabalhando tão } \\
\text { simples quanto o fôlego } \\
\text { que eu tenho de } \\
\text { orçamento para manter } \\
\text { a equipe". }\end{array}$ & $\begin{array}{l}\text { O conceito de } \\
\text { priorização é utilizado } \\
\text { para definir o que será } \\
\text { entregue dentro do } \\
\text { orçamento do projeto. }\end{array}$ \\
\hline E3 & $\begin{array}{l}\text { "A gente tem as reuniões } \\
\text { de release planning. } \\
\text { Então a gente já escreve } \\
\text { as histórias bem alto } \\
\text { nível... E aí a gente faz } \\
\text { os story points... Então } \\
\text { no nível macro a gente } \\
\text { monta as sprints da } \\
\text { release baseado nessa } \\
\text { estimativa de story } \\
\text { points". }\end{array}$ & $\begin{array}{l}\text { A equipe do projeto } \\
\text { realiza uma estimativa } \\
\text { em alto nível no início } \\
\text { do mesmo para fechar o } \\
\text { escopo de cada release. }\end{array}$ & $\begin{array}{l}\text { "Fechamos os requisitos } \\
\text { da release... Para não } \\
\text { ter desvio, que aí já é } \\
\text { muito mais assertivo a } \\
\text { questão de custo e } \\
\text { prazo... Porque nem } \\
\text { sempre o que a gente } \\
\text { achou que ia entregar na } \\
\text { release a gente entrega, } \\
\text { então pode ter desvio } \\
\text { também de } \\
\text { funcionalidade, não só } \\
\text { de custo. ". }\end{array}$ & $\begin{array}{l}\text { Pode haver desvio de } \\
\text { custo, de prazo ou de } \\
\text { funcionalidade do que } \\
\text { será entregue em cada } \\
\text { release à medida que o } \\
\text { projeto vai sendo } \\
\text { detalhado. }\end{array}$ \\
\hline E4 & $\begin{array}{l}\text { "A gente fazia um PMG } \\
\text { ou um planning poker } \\
\text { com os times e aí depois } \\
\text { a gente acompanhava por } \\
\text { um burndown, conforme } \\
\text { isso ia sendo concluído... } \\
\text { E aí, com base nisso, a } \\
\text { gente conseguia } \\
\text { confirmar que as } \\
\text { estimativas estavam } \\
\text { funcionando e também } \\
\text { aprender com as métricas } \\
\text { para dar estimativas } \\
\text { baseadas em dados". }\end{array}$ & $\begin{array}{l}\text { A organização trabalha } \\
\text { com estimativas iniciais } \\
\text { em alto nível, de acordo } \\
\text { com a classificação de } \\
\text { tamanho do projeto, e } \\
\text { acompanha o que está } \\
\text { sendo entregue durante a } \\
\text { execução. Também } \\
\text { existe um conceito de } \\
\text { melhoria contínua, } \\
\text { visando sempre a prover } \\
\text { estimativas melhores. }\end{array}$ & $\begin{array}{l}\text { "Você sai daquele } \\
\text { modelo de projetos } \\
\text { tradicional, onde eu } \\
\text { ficava dois meses só } \\
\text { junto com o gestor de } \\
\text { projeto fazendo o } \\
\text { cronograma... para } \\
\text { depois jogar tudo no } \\
\text { lixo porque mudava } \\
\text { tudo... Eu tinha um } \\
\text { projeto de } 6 \text { meses, } \\
\text { então se eu reduzo a } \\
\text { parte de planejamento já } \\
\text { reduziu bastante ele, } \\
\text { tipo uns } 20 \% \text { do tempo } \\
\text { desse projeto, porque o } \\
\text { time ia puxando e } \\
\text { fazendo". }\end{array}$ & $\begin{array}{l}\text { A entrevistada ressaltou } \\
\text { que as estimativas do } \\
\text { modelo tradicional não } \\
\text { eram cumpridas. } \\
\text { Portanto, houve uma } \\
\text { redução no prazo de } \\
\text { entrega dos projetos, } \\
\text { depois da adoção do } \\
\text { modelo ágil, devido à } \\
\text { redução do tempo de } \\
\text { planejamento. Houve } \\
\text { também redução de risco } \\
\text { no modelo ágil, quando } \\
\text { as estimativas passaram } \\
\text { a ser definidas pela } \\
\text { equipe no modelo } \\
\text { "puxado". }\end{array}$ \\
\hline
\end{tabular}

\footnotetext{
${ }^{1}$ Expressão utilizada para se referir a um projeto qualquer.
} 


\begin{tabular}{|c|c|c|c|c|}
\hline \multirow{4}{*}{ 용 } & Unidade de Análise 5 & \multicolumn{3}{|l|}{ Estimativas (Continuação) } \\
\hline & Questão & \multicolumn{3}{|c|}{$\begin{array}{l}\text { Q13: Como é feita a estimativa de custo e de prazo do projeto? A organização } \\
\text { trabalha com o conceito de MVP? }\end{array}$} \\
\hline & Subunidade & \multicolumn{3}{|l|}{ Necessidade de estimativas } \\
\hline & Mensagem principal & $\begin{array}{l}\text { Interpretação da } \\
\text { mensagem principal }\end{array}$ & Mensagem associada & $\begin{array}{l}\text { Interpretação da } \\
\text { mensagem associada }\end{array}$ \\
\hline E5 & $\begin{array}{l}\text { "A liberação de } \\
\text { orçamento, tem lugares } \\
\text { que a galera está pedindo } \\
\text { anual. E aí quando você } \\
\text { vai abrir um business } \\
\text { case você puxa dessa } \\
\text { poupança que foi aberta } \\
\text { para você. E a Equipe } \\
\text { Multidisciplinar, as áreas } \\
\text { cross, eles envolvem } \\
\text { esses caras para dizer } \\
\text { quanto eles vão gastar e } \\
\text { vai puxando dali". }\end{array}$ & $\begin{array}{l}\text { A organização trabalha } \\
\text { com a aprovação do } \\
\text { Business Case antes do } \\
\text { início do projeto, } \\
\text { incluindo estimativa de } \\
\text { custo e de prazo. }\end{array}$ & & \\
\hline E6 & $\begin{array}{l}\text { "Em época de } \\
\text { orçamento, a pessoa } \\
\text { defendia um período e } \\
\text { um custo para entregar } \\
\text { um produto com as } \\
\text { características em alto } \\
\text { nível... A gente fazia um } \\
\text { time multidisciplinar... } \\
\text { para discutir aquele } \\
\text { escopo... E aí eu já sabia } \\
\text { que ia levar oito meses, } \\
\text { com o time M, leva para } \\
\text { a diretoria e aprova... E } \\
\text { aí eu passava a reportar o } \\
\text { backlog como ele estava } \\
\text { acontecendo e o que } \\
\text { estava sendo entregue". }\end{array}$ & $\begin{array}{l}\text { A organização trabalha } \\
\text { com estimativas iniciais } \\
\text { em alto nível, de acordo } \\
\text { com a classificação de } \\
\text { tamanho do projeto e } \\
\text { acompanha o que está } \\
\text { sendo entregue durante a } \\
\text { execução. }\end{array}$ & $\begin{array}{l}\text { "A gente levava um ano } \\
\text { e meio naquele processo } \\
\text { todo, às vezes só para a } \\
\text { área de negócios } \\
\text { estimar... levava } 2,3 \\
\text { meses, e a gente } \\
\text { começou a conseguir } \\
\text { pôr o produto no } \\
\text { mercado em } 6,8 \text { meses } \\
\text { já testando ali". }\end{array}$ & $\begin{array}{l}\text { O entrevistado ressaltou } \\
\text { que houve uma redução } \\
\text { no prazo de entrega dos } \\
\text { projetos, depois da } \\
\text { adoção do modelo ágil, } \\
\text { devido à redução do } \\
\text { tempo de planejamento. }\end{array}$ \\
\hline E7 & $\begin{array}{l}\text { "A gente começou a } \\
\text { fazer o planejamento } \\
\text { anual. Eu vou gastar isso } \\
\text { daqui e tenho isso daqui } \\
\text { previsto no ano". }\end{array}$ & $\begin{array}{l}\text { A organização trabalha } \\
\text { com uma estimativa } \\
\text { anual de entregas e } \\
\text { budget associado. }\end{array}$ & $\begin{array}{l}\text { "Como a agilidade não } \\
\text { crava uma data fixa do } \\
\text { projeto como um todo... } \\
\text { você não tem uma data } \\
\text { de marco final daquele } \\
\text { projeto... Então você } \\
\text { fala, 'ah, o projeto ágil } \\
\text { não tem uma data para } \\
\text { finalizar'. Mas no } \\
\text { [modelo] cascata nunca } \\
\text { se cumpre a data } \\
\text { também. Pode até ter a } \\
\text { data, mas nunca se } \\
\text { cumpre". }\end{array}$ & $\begin{array}{l}\text { A entrevistada ressaltou } \\
\text { que as estimativas do } \\
\text { modelo tradicional } \\
\text { geralmente não são } \\
\text { cumpridas, portanto, o } \\
\text { desconhecimento sobre } \\
\text { o prazo do projeto no } \\
\text { modelo ágil não é uma } \\
\text { desvantagem. }\end{array}$ \\
\hline
\end{tabular}




\begin{tabular}{|c|c|c|c|c|}
\hline \multirow{4}{*}{ 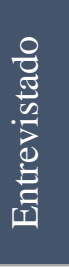 } & Unidade de Análise 5 & \multicolumn{3}{|l|}{ Estimativas (Continuação) } \\
\hline & Questão & \multicolumn{3}{|c|}{$\begin{array}{l}\text { Q13: Como é feita a estimativa de custo e de prazo do projeto? A organização } \\
\text { trabalha com o conceito de MVP? }\end{array}$} \\
\hline & Subunidade & \multicolumn{3}{|l|}{ Necessidade de estimativas } \\
\hline & Mensagem principal & $\begin{array}{c}\text { Interpretação da } \\
\text { mensagem principal }\end{array}$ & Mensagem associada & $\begin{array}{c}\text { Interpretação da } \\
\text { mensagem associada }\end{array}$ \\
\hline E8 & $\begin{array}{l}\text { "A gente não tem o olhar } \\
\text { de custo... mas o RH } \\
\text { tem, porque a gente tem } \\
\text { que lançar as nossas } \\
\text { horas... O que a gente } \\
\text { passa é só uma } \\
\text { estimativa de quantas } \\
\text { sprints vamos demorar... } \\
\text { Tanto produtos quanto os } \\
\text { executivos, a gente tem } \\
\text { um acompanhamento". }\end{array}$ & $\begin{array}{l}\text { A equipe do projeto } \\
\text { realiza apenas a } \\
\text { estimativa de prazo de } \\
\text { entrega do projeto, que é } \\
\text { acompanhada pelos } \\
\text { executivos durante a } \\
\text { execução. }\end{array}$ & $\begin{array}{l}\text { "A gente tem que avisar } \\
\text { no decorrer do } \\
\text { andamento, e sempre } \\
\text { embasado, porque que } \\
\text { não entregou. Pode } \\
\text { acontecer? Pode, mas aí } \\
\text { a gente vai registrando } \\
\text { os impedimentos no } \\
\text { meio do caminho". }\end{array}$ & $\begin{array}{l}\text { Os impedimentos devem } \\
\text { ser reportados aos } \\
\text { executivos para que, } \\
\text { caso haja algum desvio, } \\
\text { esteja embasado. }\end{array}$ \\
\hline E9 & $\begin{array}{l}\text { "Tudo é baseado no } \\
\text { OKR... Esse aqui é o } \\
\text { roadmap de ações, esses } \\
\text { são os Key Results que } \\
\text { eu pretendo atingir com } \\
\text { essas ações e essas } \\
\text { funcionalidades, para eu } \\
\text { atingir o meu objetivo } \\
\text { final". }\end{array}$ & $\begin{array}{l}\text { Não há acompanhamento } \\
\text { de prazo de entrega dos } \\
\text { projetos, apenas de } \\
\text { resultados obtidos por } \\
\text { meio de OKR's. }\end{array}$ & $\begin{array}{l}\text { "Quando o negócio é } \\
\text { meio importante, assim, } \\
\text { estratégico, eles querem } \\
\text { saber prazo. Quando o } \\
\text { negócio é menos } \\
\text { estratégico, eles só } \\
\text { querem saber se você } \\
\text { está atingindo o OKR } \\
\text { ou não". }\end{array}$ & $\begin{array}{l}\text { Os executivos requerem } \\
\text { um prazo de entrega } \\
\text { apenas quando o projeto } \\
\text { é estratégico. }\end{array}$ \\
\hline E10 & $\begin{array}{l}\text { "[A estimativa] é cascata } \\
\text { até chegar no prazo e } \\
\text { custo... E a squad vai } \\
\text { dizer, porque como o } \\
\text { custo é fixo, eles só } \\
\text { precisam validar o prazo, } \\
\text { então se aquele prazo } \\
\text { estimado é aquele } \\
\text { mesmo que o time de } \\
\text { Arquitetura e Demandas } \\
\text { estimou ou não". }\end{array}$ & $\begin{array}{l}\text { Para os projetos ágeis, a } \\
\text { estimativa não é feita } \\
\text { pela mesma equipe que } \\
\text { os desenvolve, podendo } \\
\text { gerar divergências entre } \\
\text { a estimativa e a } \\
\text { execução. }\end{array}$ & $\begin{array}{l}\text { "Eles querem um } \\
\text { planejamento detalhado } \\
\text { com entrega rápida. Eu } \\
\text { falei: 'gente, isso tem } \\
\text { um nome, isso chama } \\
\text { Go Horse'. Não existe } \\
\text { planejamento detalhado } \\
\text { com entrega rápida, isso } \\
\text { não funciona". }\end{array}$ & $\begin{array}{l}\text { O entrevistado ressaltou } \\
\text { a dificuldade de manter } \\
\text { um modelo híbrido de } \\
\text { estimativas, com } \\
\text { planejamento detalhado } \\
\text { do modelo tradicional e } \\
\text { execução rápida do } \\
\text { modelo ágil. }\end{array}$ \\
\hline MP & \multicolumn{4}{|c|}{$\begin{array}{l}\text { Ainda há grande dificuldade de aceitação pelas organizações da execução dos projetos sem prazo } \\
\text { definido. Apenas dois dos entrevistados informaram que suas organizações não requeriam o prazo para a } \\
\text { entrega do projeto. Mesmo as que trabalhavam com estimativas em alto nível, no início do projeto, ainda } \\
\text { precisavam reportar os desvios aos executivos, mantendo, em alguns casos, o modelo tradicional de } \\
\text { aprovação de Change Requests. Outro fato apontado pelos entrevistados foi que o prazo definido no } \\
\text { modelo tradicional, na maioria das vezes, não é cumprido, portanto, o desconhecimento sobre o prazo do } \\
\text { projeto no modelo ágil não é uma desvantagem. Sendo assim, deve-se levar em conta a vantagem de } \\
\text { entrega mais rápida no modelo ágil, devido à redução do tempo de planejamento tradicional. }\end{array}$} \\
\hline
\end{tabular}

Fonte: Quadro elaborado pela autora, com base nas entrevistas.

b) Conceito de MVP (Mínimo Produto Viável)

Outra grande dificuldade apontada pelos entrevistados é a aceitação do conceito de MVP pela organização. Dois dos entrevistados (E2 e E10) relataram a dificuldade das organizações em aceitarem o modelo de experimentação e o lançamento de MVP's de baixa qualidade no mercado. Apenas dois dos entrevistados (E6 e E9) informaram que aplicavam o 
conceito de MVP nas organizações e, mesmo assim, detalharam as dificuldades de entregarem um produto inacabado no mercado, de lidar com o conceito de pronto e de ter áreas não ágeis na companhia (Quadro 16).

Quadro 16 - Análise da coleta de dados: Estimativas - Conceito de MVP

\begin{tabular}{|c|c|c|c|c|}
\hline \multirow{4}{*}{ 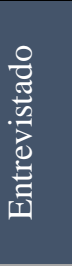 } & Unidade de Análise 5 & \multicolumn{3}{|l|}{ Estimativas } \\
\hline & Questão & \multicolumn{3}{|c|}{$\begin{array}{l}\text { Q13: Como é feita a estimativa de custo e de prazo do projeto? A } \\
\text { organização trabalha com o conceito de MVP? }\end{array}$} \\
\hline & Subunidade & \multicolumn{3}{|l|}{ Conceito de MVP } \\
\hline & Mensagem principal & $\begin{array}{c}\text { Interpretação da } \\
\text { mensagem principal }\end{array}$ & Mensagem associada & $\begin{array}{c}\text { Interpretação da } \\
\text { mensagem associada }\end{array}$ \\
\hline $\mathbf{E} 2$ & $\begin{array}{l}\text { "A gente tem MVP's de } \\
\text { baixíssima qualidade, } \\
\text { então, assim, não é um } \\
\text { mínimo produto viável". }\end{array}$ & $\begin{array}{l}\text { Risco de lançamento do } \\
\text { produto sem qualidade } \\
\text { suficiente, mesmo no } \\
\text { modelo de } \\
\text { experimentação. }\end{array}$ & & \\
\hline E6 & $\begin{array}{l}\text { "A gente levava um ano } \\
\text { e meio naquele processo } \\
\text { todo... e a gente } \\
\text { começou a conseguir } \\
\text { pôr o produto no } \\
\text { mercado em } 6,8 \text { meses } \\
\text { já testando ali". }\end{array}$ & $\begin{array}{l}\text { Redução no tempo de } \\
\text { lançamento dos } \\
\text { produtos com a adoção } \\
\text { do conceito de MVP. }\end{array}$ & $\begin{array}{l}\text { "Começou a ter uma } \\
\text { dificuldade de lidar com } \\
\text { o conceito de pronto... } \\
\text { Tem um monte de coisa } \\
\text { ainda que precisa ser } \\
\text { melhorada... Você } \\
\text { começa a ter o produto } \\
\text { do ponto de vista MVP } \\
\text { no mercado, mas não } \\
\text { está no padrão dos } \\
\text { outros produtos. Então } \\
\text { você cria outros } \\
\text { problemas". }\end{array}$ & $\begin{array}{l}\text { Dificuldade em } \\
\text { comparar o tempo de } \\
\text { lançamento de um } \\
\text { produto pronto (no } \\
\text { modelo tradicional) com } \\
\text { um MVP (modelo ágil). }\end{array}$ \\
\hline E9 & $\begin{array}{l}\text { "O conceito de MVP } \\
\text { está bem enraizado. Tem } \\
\text { que entregar alguma } \\
\text { coisa, tem que começar } \\
\text { com um MVP. Você vai } \\
\text { evoluindo". }\end{array}$ & $\begin{array}{l}\text { A área de Digital da } \\
\text { organização trabalha } \\
\text { muito bem com o } \\
\text { conceito de MVP. }\end{array}$ & $\begin{array}{l}\text { "Ainda tem gente que só } \\
\text { aceita projeto } \\
\text { completo... De } 350 \\
\text { itens que eles queriam } \\
\text { desenvolver, o MVP } \\
\text { deles tinha 250. Então, } \\
\text { assim, eles não } \\
\text { entendem". }\end{array}$ & $\begin{array}{l}\text { Nas áreas ainda não } \\
\text { migradas para o ágil, } \\
\text { ainda há dificuldade por } \\
\text { parte da organização em } \\
\text { aceitar o lançamento de } \\
\text { um produto no mercado } \\
\text { sem todas as } \\
\text { funcionalidades. }\end{array}$ \\
\hline E10 & $\begin{array}{l}\text { "Os 'caras' têm a cultura } \\
\text { de produto pronto... } \\
\text { Então, essa ideia do } \\
\text { MVP, para eles, é o } \\
\text { 'produto para } \\
\text { lançamento', não } \\
\text { necessariamente o } \\
\text { mínimo viável... Eles } \\
\text { não perceberam o que é } \\
\text { o MVP, o que é entregar } \\
\text { por experimentação". }\end{array}$ & $\begin{array}{l}\text { Dificuldade por parte da } \\
\text { organização em aceitar } \\
\text { o lançamento de um } \\
\text { produto no mercado } \\
\text { sem todas as } \\
\text { funcionalidades. }\end{array}$ & $\begin{array}{l}\text { "Ela não entende que a } \\
\text { gente precisa entregar } \\
\text { rápido, errar rápido e } \\
\text { experimentar... A parte } \\
\text { toda de experimentação, } \\
\text { não é bem vista porque } \\
\text { eles pensam, como a } \\
\text { gente vai chegar, vai } \\
\text { botar um troço no } \\
\text { mercado e vai errar?" }\end{array}$ & $\begin{array}{l}\text { Dificuldade em lançar } \\
\text { um produto passível de } \\
\text { erros no mercado e de } \\
\text { lidar com o conceito de } \\
\text { experimentação. }\end{array}$ \\
\hline MP & $\begin{array}{l}\text { Houve grande dificuldade } \\
\text { "inacabados" no mercado } \\
\text { de produtos no menor t } \\
\text { qualidade, sem pensar no }\end{array}$ & $\begin{array}{l}\text { or parte das organiza } \\
\text { eguindo o conceito d }\end{array}$ & radicionais em aceitar & $\begin{array}{l}\text { ançamento de produtos } \\
\text { ressão pelo lançamento } \\
\text { ado produtos de baixa }\end{array}$ \\
\hline
\end{tabular}

Fonte: Quadro elaborado pela autora, com base nas entrevistas. 
c) Priorização

Alguns dos entrevistados afirmaram que a organização possui dificuldade na priorização das histórias da sprint, muitas vezes alterando o escopo durante sua execução devido a decisões dos executivos. Os entrevistados E2 e E3, ambos da Empresa B, também descreveram as dificuldades de a organização trabalhar internamente com a priorização dos projetos, impactando tanto no prazo dos projetos quanto na produtividade e na satisfação da equipe. Apenas o entrevistado E7 informou que a organização trabalha com o conceito de priorização, considerado um grande benefício do modelo ágil (Quadro 17).

Quadro 17 - Análise da coleta de dados: Estimativas - Priorização

\begin{tabular}{|c|c|c|c|c|}
\hline \multirow{4}{*}{ 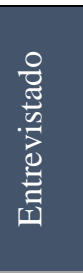 } & Unidade de Análise 5 & \multicolumn{3}{|l|}{ Estimativas } \\
\hline & Questão & \multicolumn{3}{|c|}{$\begin{array}{l}\text { Q13: Como é feita a estimativa de custo e de prazo do projeto? A } \\
\text { organização trabalha com o conceito de MVP? }\end{array}$} \\
\hline & Subunidade & \multicolumn{3}{|l|}{ Priorização } \\
\hline & Mensagem principal & $\begin{array}{l}\text { Interpretação da } \\
\text { mensagem principal }\end{array}$ & Mensagem associada & $\begin{array}{l}\text { Interpretação da } \\
\text { mensagem associada }\end{array}$ \\
\hline $\mathbf{E 2}$ & $\begin{array}{l}\text { "O grande desafio da } \\
\text { Empresa B, não } \\
\text { superado, se chama } \\
\text { priorizar... tudo tem que } \\
\text { ser para ontem. Então é } \\
\text { muita coisa acontecendo } \\
\text { ao mesmo tempo e se a } \\
\text { gente não sabe priorizar } \\
\text { a gente acaba } \\
\text { negligenciando, digamos } \\
\text { assim, o que é a prática } \\
\text { do ágil". }\end{array}$ & $\begin{array}{l}\text { A dificuldade da } \\
\text { organização em } \\
\text { priorizar projetos gera a } \\
\text { sobrecarga de atividades } \\
\text { para as equipes e a } \\
\text { perda de produtividade. }\end{array}$ & $\begin{array}{l}\text { "Quando a gente não } \\
\text { foca e não sabe } \\
\text { priorizar, a gente tem } \\
\text { times que se desgastam } \\
\text { muito... e isso acaba } \\
\text { mexendo muito com a } \\
\text { organização, então você } \\
\text { tem um clima muito } \\
\text { mais difícil". }\end{array}$ & $\begin{array}{l}\text { A falta de entendimento } \\
\text { em relação ao que é } \\
\text { importante para a } \\
\text { organização gera } \\
\text { impacto na } \\
\text { produtividade e na } \\
\text { satisfação da equipe. }\end{array}$ \\
\hline $\mathbf{E 3}$ & $\begin{array}{l}\text { "Tudo é prioritário. As } \\
\text { coisas se conflitam; os } \\
\text { projetos não se conver- } \\
\text { sam. Como está todo } \\
\text { mundo ali no desespero } \\
\text { de entregar o seu, você } \\
\text { não olha o todo". }\end{array}$ & $\begin{array}{l}\text { A dificuldade da } \\
\text { organização em } \\
\text { priorizar projetos gera } \\
\text { sobrecarga de atividades } \\
\text { para as equipes e perda } \\
\text { de produtividade. }\end{array}$ & & \\
\hline E7 & $\begin{array}{l}\text { "A gente trabalha muito } \\
\text { o conceito de valor... isso } \\
\text { aqui realmente está } \\
\text { trazendo valor? Por que } \\
\text { você está colocando isso } \\
\text { dentro dessa sprint? Isso } \\
\text { realmente é o mais } \\
\text { importante? Antes eu } \\
\text { não questionava, vinha. } \\
\text { Eles falavam: 'é para ser } \\
\text { entregue isso'. Ninguém } \\
\text { falava se trazia valor ou } \\
\text { não. Agora não, tudo se } \\
\text { questiona se traz valor } \\
\text { ou não". }\end{array}$ & $\begin{array}{l}\text { A organização } \\
\text { conseguiu mudar o } \\
\text { mindset para priorizar } \\
\text { apenas as atividades que } \\
\text { geravam valor para a } \\
\text { empresa. }\end{array}$ & & (Continua) \\
\hline
\end{tabular}




\begin{tabular}{|c|c|c|c|c|}
\hline \multirow{4}{*}{ 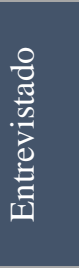 } & Unidade de Análise 5 & \multicolumn{3}{|l|}{ Estimativas (Continuação) } \\
\hline & Questão & \multicolumn{3}{|c|}{$\begin{array}{l}\text { Q13: Como é feita a estimativa de custo e de prazo do projeto? A } \\
\text { organização trabalha com o conceito de MVP? }\end{array}$} \\
\hline & Subunidade & \multicolumn{3}{|l|}{ Priorização } \\
\hline & Mensagem principal & $\begin{array}{l}\text { Interpretação da } \\
\text { mensagem principal }\end{array}$ & Mensagem associada & $\begin{array}{l}\text { Interpretação da } \\
\text { mensagem associada }\end{array}$ \\
\hline E8 & $\begin{array}{l}\text { "Chega o executivo } \\
\text { pedindo uma coisa que } \\
\text { para ele faz sentido... } \\
\text { porque é uma } \\
\text { oportunidade, então tem } \\
\text { que atender". }\end{array}$ & $\begin{array}{l}\text { Dificuldade em manter } \\
\text { o escopo da sprint, } \\
\text { devido à intervenção } \\
\text { dos executivos durante a } \\
\text { sua execução, mantendo } \\
\text { o modelo top-down de } \\
\text { tomada de decisões. }\end{array}$ & $\begin{array}{l}\text { "Ele [executivo] não } \\
\text { entende como } \\
\text { funcionam as } \\
\text { prioridades, o backlog. } \\
\text { Falta um pouco esse } \\
\text { entendimento... E por } \\
\text { mais que você como } \\
\text { SM tente falar... ainda } \\
\text { vale o crachá". }\end{array}$ & $\begin{array}{l}\text { Falta de conhecimento } \\
\text { em relação ao modelo } \\
\text { ágil pelo executivo, } \\
\text { demandando a } \\
\text { participação nos } \\
\text { treinamentos. }\end{array}$ \\
\hline E9 & $\begin{array}{l}\text { "A gente precisa } \\
\text { melhorar a maturidade } \\
\text { dos times ágeis... saber } \\
\text { priorizar corretamente } \\
\text { uma determinada } \\
\text { funcionalidade. Olhar o } \\
\text { OKR antes de sair } \\
\text { desenvolvendo. } \\
\text { Aprender a fazer } \\
\text { pesquisa com o cliente, } \\
\text { antes de desenvolver, } \\
\text { não pós } \\
\text { desenvolvimento". }\end{array}$ & $\begin{array}{l}\text { Apesar de já utilizar a } \\
\text { priorização como } \\
\text { conceito na área de } \\
\text { Digital, ainda há a } \\
\text { necessidade de melhorar } \\
\text { o nível de maturidade } \\
\text { para priorizar as } \\
\text { funcionalidades, de } \\
\text { acordo com o resultado } \\
\text { obtido ou com o } \\
\text { feedback do cliente". }\end{array}$ & & \\
\hline E10 & $\begin{array}{l}\text { "Eles querem a qualquer } \\
\text { momento poder incluir e } \\
\text { retirar coisas. Ah, mas } \\
\text { não é ágil? Ágil eu posso } \\
\text { incluir e retirar". }\end{array}$ & $\begin{array}{l}\text { Dificuldade em manter } \\
\text { o escopo da sprint, } \\
\text { devido à intervenção da } \\
\text { área de Produtos durante } \\
\text { a sua execução. }\end{array}$ & $\begin{array}{l}\text { "Se a gente não } \\
\text { conseguir dar o foco por } \\
\text { pelo menos } 15 \text { dias, a } \\
\text { gente vai começar a ter } \\
\text { perda de tempo na } \\
\text { mudança de foco". }\end{array}$ & $\begin{array}{l}\text { A alternância da } \\
\text { priorização definida } \\
\text { gera impacto na } \\
\text { produtividade e na } \\
\text { satisfação da equipe. }\end{array}$ \\
\hline MP & \multicolumn{4}{|c|}{$\begin{array}{l}\text { A priorização de projetos e de funcionalidades de acordo com o valor para o negócio ainda é um desafio } \\
\text { para as organizações, pois requer mudança de mindset em todos os níveis hierárquicos. A mudança } \\
\text { constante de priorização e a tomada de decisões de forma top-down foram fatores de grande insatisfação } \\
\text { e de perda da produtividade das equipes, além de impactarem no prazo de entrega dos projetos. }\end{array}$} \\
\hline
\end{tabular}

Fonte: Quadro elaborado pela autora, com base nas entrevistas.

4.2.1.6 Relatórios de status - coleta de dados primários (UA 6)

A literatura recomenda que os relatórios de status sejam adaptados ao modelo ágil, utilizando gráficos de burndown ou indicadores simples de acompanhamento, além da validação do software ao invés de relatório. Os entrevistados E1 e E5 informaram que a organização ainda mantém a prática de elaboração de Status Report (Relatórios de Status), mesmo depois da adoção do modelo ágil. Os entrevistados E6, E7 e E9 relataram que não existe mais o conceito de Status Report estimulando as práticas de gestão visual nas squads ou por meio de uma ferramenta de disponibilização de informações. O entrevistado E10 
afirmou que foi necessário retomar a um modelo híbrido de divulgação das informações, devido à não adesão da organização aos ritos ágeis (Quadro 18).

\section{Quadro 18 - Análise da coleta de dados: Relatórios de status}

\begin{tabular}{|c|c|c|c|c|}
\hline \multirow{3}{*}{ 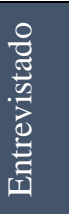 } & Unidade de Análise 6 & \multicolumn{3}{|c|}{ Relatórios de status (Status Report) } \\
\hline & Questão & \multicolumn{3}{|c|}{$\begin{array}{l}\text { Q14: Como é feito o acompanhamento de acordo com esta estimativa? A } \\
\text { gestão da empresa está confortável com estes reportes? }\end{array}$} \\
\hline & Mensagem principal & $\begin{array}{l}\text { Interpretação da } \\
\text { mensagem principal }\end{array}$ & Mensagem associada & $\begin{array}{l}\text { Interpretação da } \\
\text { mensagem associada }\end{array}$ \\
\hline E1 & $\begin{array}{l}\text { "A gente envia um } \\
\text { status report, que pode } \\
\text { ter gráficos ou somente } \\
\text { texto. Squads mais } \\
\text { maduras têm } \\
\text { burndown". }\end{array}$ & $\begin{array}{l}\text { O Status Report é } \\
\text { enviado pelo GP mesmo } \\
\text { para os projetos ágeis. }\end{array}$ & $\begin{array}{l}\text { "Cronograma macro e } \\
\text { acompanhamento do } \\
\text { orçamento têm em todos } \\
\text { os status reports dos } \\
\text { projetos". }\end{array}$ & $\begin{array}{l}\text { A organização ainda } \\
\text { requer um } \\
\text { acompanhamento de } \\
\text { prazo e de custo do } \\
\text { projeto. }\end{array}$ \\
\hline E5 & $\begin{array}{l}\text { "Aí você tomba para o } \\
\text { ágil e o cara não tem } \\
\text { entrada no dia a dia de } \\
\text { squad. Ocara precisa } \\
\text { fazer status report. Aí } \\
\text { vira o chato } \\
\text { perguntando, porque } \\
\text { efetivamente esse cara } \\
\text { não está no dia a dia". }\end{array}$ & $\begin{array}{l}\text { O Status Report é } \\
\text { enviado pelo GP mesmo } \\
\text { para os projetos ágeis, } \\
\text { porém o entrevistado } \\
\text { ressaltou que o papel do } \\
\text { GP não faz sentido } \\
\text { neste caso. }\end{array}$ & & \\
\hline E6 & $\begin{array}{l}\text { "A gente criou farol, se } \\
\text { você olhar todos os } \\
\text { quadros de gestão visual } \\
\text { tinham faróis. A gente } \\
\text { conseguiu comprar } \\
\text { aquelas luminárias de } \\
\text { piscina que você } \\
\text { conseguiria mudar de } \\
\text { cor. Então quando a } \\
\text { squad estava com um } \\
\text { problema, a gente } \\
\text { mudava de cor, você } \\
\text { olhava e sabia em qual } \\
\text { squad você tinha que ir. }\end{array}$ & $\begin{array}{l}\text { A equipe passou a criar } \\
\text { várias opções de gestão } \\
\text { visual para substituir o } \\
\text { Status Report. }\end{array}$ & $\begin{array}{l}\text { "Aquele hábito dos } \\
\text { executivos de esperar o } \\
\text { status report na mesa } \\
\text { deles...ou aquela } \\
\text { reunião de Status Report } \\
\text { semanal, onde a gente } \\
\text { passou a provocar que } \\
\text { eles passassem a ir nas } \\
\text { squads de gestão } \\
\text { visual". }\end{array}$ & $\begin{array}{l}\text { Houve certa resistência } \\
\text { dos executivos em não } \\
\text { receberem o relatório da } \\
\text { forma como estavam } \\
\text { acostumados e a } \\
\text { passarem a ter que ir nas } \\
\text { squads. }\end{array}$ \\
\hline E7 & $\begin{array}{l}\text { "Eu falei: 'gente, isso } \\
\text { aqui não é Status } \\
\text { Report. Vocês precisam } \\
\text { se conversar. Eu não } \\
\text { vou ficar perguntando } \\
\text { nada'. Agora como } \\
\text { Gerente de Projetos eu } \\
\text { chegava lá perguntando. } \\
\text { Então mudou } \\
\text { completamente". }\end{array}$ & $\begin{array}{l}\text { A SM relatou que } \\
\text { compartilhou com a } \\
\text { equipe a } \\
\text { responsabilidade do } \\
\text { status do projeto e } \\
\text { explicou a necessidade } \\
\text { de todos se sentirem } \\
\text { responsáveis pelo } \\
\text { projeto ao invés de se } \\
\text { sentirem "cobrados" } \\
\text { pelo GP. }\end{array}$ & & \\
\hline
\end{tabular}

(Continua) 


\begin{tabular}{|c|c|c|c|c|}
\hline \multirow{3}{*}{ 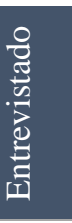 } & Unidade de Análise 6 & \multicolumn{3}{|c|}{ Relatórios de status (Status Report) (Continuação) } \\
\hline & Questão & \multicolumn{3}{|c|}{$\begin{array}{l}\text { Q14: Como é feito o acompanhamento de acordo com esta estimativa? A } \\
\text { gestão da empresa está confortável com estes reportes? }\end{array}$} \\
\hline & Mensagem principal & $\begin{array}{l}\text { Interpretação da } \\
\text { mensagem principal }\end{array}$ & Mensagem associada & $\begin{array}{c}\text { Interpretação da } \\
\text { mensagem associada }\end{array}$ \\
\hline E9 & $\begin{array}{l}\text { "Eu criei um } \\
\text { Sharepoint. Dentro do } \\
\text { Sharepoint, eu abri uma } \\
\text { página para cada } \\
\text { squad... E com esse } \\
\text { modelo, eu divulguei } \\
\text { essas páginas do } \\
\text { Sharepoint e falei: } \\
\text { 'agora eu não preciso } \\
\text { mais ficar fazendo } \\
\text { apresentação de } \\
\text { resultados'". }\end{array}$ & $\begin{array}{l}\text { A entrevistada relatou } \\
\text { que as informações } \\
\text { ficam disponíveis em } \\
\text { uma ferramenta, que } \\
\text { pode ser acessada por } \\
\text { todos da organização } \\
\text { para saber o status dos } \\
\text { projetos. }\end{array}$ & & \\
\hline E10 & $\begin{array}{l}\text { "Ela [PO] acha que tem } \\
\text { que ter a reunião de } 3 \\
\text { P's: o que aconteceu no } \\
\text { passado, o que está } \\
\text { acontecendo no } \\
\text { presente, e os próximos } \\
\text { passos. Ou seja, reunião } \\
\text { de status normal, status } \\
\text { report". }\end{array}$ & $\begin{array}{l}\text { O entrevistado relatou o } \\
\text { abandono do rito das } \\
\text { dailies e o retorno ao } \\
\text { modelo tradicional de } \\
\text { Status Report. }\end{array}$ & $\begin{array}{l}\text { "A reclamação das } \\
\text { dailies é porque eu não } \\
\text { tinha tempo, mas você } \\
\text { vai gastar o mesmo } \\
\text { tempo que você gastaria } \\
\text { numa daily". }\end{array}$ & $\begin{array}{l}\text { A falta de engajamento } \\
\text { das equipes gerou o } \\
\text { churn da aplicação das } \\
\text { práticas ágeis e retorno } \\
\text { ao modelo tradicional. }\end{array}$ \\
\hline MP & \multicolumn{4}{|c|}{$\begin{array}{l}\text { Ainda há demanda por parte dos executivos das organizações em receberem formalmente o Status } \\
\text { Report do projeto. A visibilidade do modelo ágil traz outras opções de Status Report, que demandam } \\
\text { uma mudança de mindset pela organização para acessar as informações disponíveis. }\end{array}$} \\
\hline
\end{tabular}

Fonte: Quadro elaborado pela autora, com base nas entrevistas.

4.2.1.7 Comunicação - coleta de dados primários (UA 8)

A comunicação é um dos pontos críticos da transição, pois requer uma mudança para o modelo ágil de colaboração entre os membros da equipe, sem os processos formais do modelo tradicional.

a) Melhoria na comunicação

Seis dos entrevistados (E1, E2, E4, E5, E6 e E7) informaram que a comunicação melhorou depois da adoção do modelo ágil, principalmente no interior da equipe. O benefício é maior quando a equipe está próxima, reduzindo barreiras de comunicação entre o PO e a equipe de desenvolvimento. Os entrevistados E8, E9 e E10, por sua vez, acreditam que a comunicação entre as áreas ainda é um desafio. Apenas um dos entrevistados (E3) informou que a comunicação piorou depois da implantação do modelo ágil, devido à realização de 
muitos projetos simultâneos e à consequente falta de tempo dos membros das equipes (Quadro 19).

Quadro 19 - Análise da coleta de dados: Comunicação - Melhoria na comunicação

\begin{tabular}{|c|c|c|c|c|}
\hline \multirow{4}{*}{ 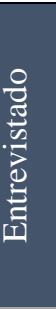 } & Unidade de Análise 8 & \multicolumn{3}{|l|}{ Comunicação } \\
\hline & Questão & \multirow{2}{*}{\multicolumn{3}{|c|}{$\begin{array}{l}\text { Q17: A comunicação entre as equipes melhorou? Atualmente, como é a } \\
\text { comunicação interna da equipe e com as outras áreas? Como era } \\
\text { anteriormente? } \\
\text { Melhoria na comunicação }\end{array}$}} \\
\hline & Subunidade & & & \\
\hline & Mensagem principal & $\begin{array}{l}\text { Interpretação da } \\
\text { mensagem principal }\end{array}$ & Mensagem associada & $\begin{array}{l}\text { Interpretação da } \\
\text { mensagem principal }\end{array}$ \\
\hline E1 & $\begin{array}{l}\text { "Melhorou muito... Os } \\
\text { principais ganhos são } \\
\text { quando o PO está } \\
\text { presente. E o } \\
\text { compartilhamento de } \\
\text { informações entre DEV e } \\
\text { QA. }\end{array}$ & $\begin{array}{l}\text { Houve melhoria na } \\
\text { comunicação com o } \\
\text { modelo ágil, } \\
\text { principalmente entre as } \\
\text { áreas de Negócios e a } \\
\text { de Tecnologia. }\end{array}$ & & \\
\hline E2 & $\begin{array}{l}\text { "Indicador de } \\
\text { comunicação nós não } \\
\text { temos... Comunicação é } \\
\text { um pouco difícil de você } \\
\text { medir, mas eu acho que é } \\
\text { nítida a melhoria na } \\
\text { comunicação". }\end{array}$ & $\begin{array}{l}\text { Houve melhoria na } \\
\text { comunicação com o } \\
\text { modelo ágil, porém é } \\
\text { percepção da própria } \\
\text { entrevistada, pois o } \\
\text { tema é subjetivo. }\end{array}$ & & \\
\hline $\mathbf{E 3}$ & $\begin{array}{l}\text { "Piorou... ninguém tem } \\
\text { tempo de ler } e \text {-mail... Mas } \\
\text { em contrapartida... essa } \\
\text { facilidade de falar em } \\
\text { grupo, de estar online, } \\
\text { então, isso acabou } \\
\text { ajudando a fazer as } \\
\text { coisas". }\end{array}$ & $\begin{array}{l}\text { A comunicação piorou } \\
\text { depois da implantação } \\
\text { do modelo ágil, devido } \\
\text { à falta de priorização } \\
\text { da organização. Porém, } \\
\text { atualmente a } \\
\text { tecnologia auxilia } \\
\text { neste gap. }\end{array}$ & & \\
\hline E4 & $\begin{array}{l}\text { "A Empresa C focou } \\
\text { muito na aplicação de } \\
\text { práticas dentro do time, } \\
\text { mas a questão de } \\
\text { interdependência, a } \\
\text { comunicação intra-times, } \\
\text { intra-áreas, a gente não } \\
\text { chegou a trabalhar isso". }\end{array}$ & $\begin{array}{l}\text { Houve melhoria na } \\
\text { comunicação interna } \\
\text { das equipes, mas não } \\
\text { entre elas. }\end{array}$ & & \\
\hline E5 & $\begin{array}{l}\text { "Melhorou... temos } \\
\text { evoluído aos poucos, mas } \\
\text { estamos evoluindo... Em } \\
\text { algumas esteiras o pessoal } \\
\text { de negócios já está } \\
\text { "sentando' perto de TI". }\end{array}$ & $\begin{array}{l}\text { Houve melhoria na } \\
\text { comunicação com o } \\
\text { modelo ágil, } \\
\text { principalmente, entre } \\
\text { as áreas de Negócios e } \\
\text { de Tecnologia. }\end{array}$ & & \\
\hline E6 & $\begin{array}{l}\text { "A gente rodava Daily... } \\
\text { um GP que está passando } \\
\text { por um problema, o } \\
\text { Scrum Master tinha uma } \\
\text { informação que podia } \\
\text { ajudar, então, isso foi } \\
\text { realmente muito bom". }\end{array}$ & $\begin{array}{l}\text { Houve melhoria na } \\
\text { comunicação interna } \\
\text { da equipe. }\end{array}$ & $\begin{array}{l}\text { "Do ponto de vista da } \\
\text { informação executiva, aí } \\
\text { não evoluiu muito". }\end{array}$ & $\begin{array}{l}\text { Não houve melhoria na } \\
\text { comunicação no nível } \\
\text { executivo. Eles ainda } \\
\text { esperam uma } \\
\text { comunicação formal } \\
\text { (por exemplo, o Status } \\
\text { Report). }\end{array}$ \\
\hline
\end{tabular}




\begin{tabular}{|c|c|c|c|c|}
\hline \multirow{4}{*}{ 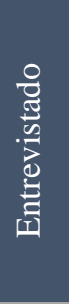 } & Unidade de Análise 8 & \multicolumn{3}{|c|}{ Comunicação (Continuação) } \\
\hline & Questão & \multicolumn{3}{|c|}{$\begin{array}{l}\text { Q17: A comunicação entre as equipes melhorou? Atualmente, como é a } \\
\text { comunicação interna da equipe e com as outras áreas? Como era } \\
\text { anteriormente? }\end{array}$} \\
\hline & Subunidade & \multicolumn{3}{|l|}{ Melhoria na comunicação } \\
\hline & Mensagem principal & $\begin{array}{l}\text { Interpretação da } \\
\text { mensagem principal }\end{array}$ & Mensagem associada & $\begin{array}{l}\text { Interpretação da } \\
\text { mensagem principal }\end{array}$ \\
\hline E7 & $\begin{array}{l}\text { "O ágil aproxima mais as } \\
\text { pessoas... A própria } \\
\text { equipe pode tirar de } \\
\text { impedimento se } \\
\text { relacionando com os } \\
\text { demais". }\end{array}$ & $\begin{array}{l}\text { Houve melhoria na } \\
\text { comunicação interna } \\
\text { da equipe. }\end{array}$ & $\begin{array}{l}\text { "Vai muito da } \\
\text { personalidade de cada } \\
\text { um, porque tem gente } \\
\text { que não gosta de ajudar. } \\
\text { Mas, no geral, o ágil } \\
\text { promove isso". }\end{array}$ & $\begin{array}{l}\text { A comunicação } \\
\text { depende da } \\
\text { personalidade das } \\
\text { pessoas e não somente } \\
\text { do modelo ágil. }\end{array}$ \\
\hline E8 & $\begin{array}{l}\text { "A comunicação ainda é } \\
\text { uma dor... A agilidade } \\
\text { não trabalhou a } \\
\text { comunicação... O meu } \\
\text { time é bem alinhado... é } \\
\text { muito transparente... Mas, } \\
\text { são vários times e, às } \\
\text { vezes o pessoal no topo } \\
\text { pensa em alguma coisa, } \\
\text { fala com alguns e isso não } \\
\text { dá sintonia em todo } \\
\text { mundo". }\end{array}$ & $\begin{array}{l}\text { A comunicação ainda é } \\
\text { um desafio para a } \\
\text { organização. Houve } \\
\text { melhoria na } \\
\text { comunicação interna } \\
\text { das equipes, mas não } \\
\text { entre elas. }\end{array}$ & $\begin{array}{l}\text { "Entrou uma outra } \\
\text { pessoa... que permeia por } \\
\text { todas as squads... o SM } \\
\text { dos SM's. Então, hoje a } \\
\text { gente já não tem mais } \\
\text { essa dor, porque ele sabe } \\
\text { do que eu estou fazendo, } \\
\text { ele sabe do que o outro } \\
\text { faz. E se precisar ele } \\
\text { interage com a gente". }\end{array}$ & $\begin{array}{l}\text { Importância de haver na } \\
\text { organização um papel } \\
\text { de integração entre as } \\
\text { squads. }\end{array}$ \\
\hline E9 & $\begin{array}{l}\text { "Eu como responsável } \\
\text { pela governança... sendo } \\
\text { o elo de comunicação das } \\
\text { pessoas... está bem } \\
\text { centralizado na minha } \\
\text { área, e é um trabalho bem } \\
\text { difícil, mas o nosso maior } \\
\text { desafio seguramente é a } \\
\text { comunicação". }\end{array}$ & $\begin{array}{l}\text { A comunicação ainda é } \\
\text { um desafio para a } \\
\text { organização. }\end{array}$ & $\begin{array}{l}\text { "A gente tem Syncs... que } \\
\text { são reuniões de } \\
\text { sincronismo... A gente } \\
\text { discute sempre } \\
\text { interdependências". }\end{array}$ & $\begin{array}{l}\text { Importância de haver na } \\
\text { organização um papel } \\
\text { de integração entre as } \\
\text { squads. }\end{array}$ \\
\hline E10 & $\begin{array}{l}\text { "Nós temos um monte de } \\
\text { nichos, um monte de } \\
\text { feudos... dentro do } \\
\text { portfólio... tem vários } \\
\text { projetos. E tem as dailies } \\
\text { nossas... com o gerente de } \\
\text { portfólio. Porque esse } \\
\text { gerente de portfólio é um } \\
\text { nomeado para ir às } \\
\text { reuniões mais } \\
\text { importantes". }\end{array}$ & $\begin{array}{l}\text { Existe o papel de } \\
\text { gerente de portfólio, } \\
\text { que realiza a } \\
\text { integração entre todos } \\
\text { os projetos. }\end{array}$ & & \\
\hline MP & \multicolumn{4}{|c|}{$\begin{array}{l}\text { A percepção de alguns dos entrevistados foi de que, com o modelo ágil, houve melhoria na comunicação } \\
\text { interna da equipe e entre as áreas de Tecnologia e de Negócios, devido à formação das equipes } \\
\text { multidisciplinares. Porém, a comunicação ainda é um desafio para algumas organizaçôes e, mesmo com } \\
\text { o modelo ágil, diversos entrevistados relataram a dificuldade na comunicação entre as áreas. É } \\
\text { importante a criação de um papel de integração para realizar o sincronismo entre as equipes e minimizar } \\
\text { o problema de comunicação. }\end{array}$} \\
\hline
\end{tabular}

Fonte: Quadro elaborado pela autora, com base nas entrevistas. 
b) Visibilidade do modelo ágil

Outro ponto citado por cinco dos entrevistados (E2, E4, E5, E7 e E10) é a visibilidade que o modelo ágil traz, principalmente por meio dos ritos, evidenciando não apenas o trabalho que vem sendo realizado pelas equipes, mas também os problemas encontrados (Quadro 20).

Quadro 20 - Análise da coleta de dados: Comunicação - Visibilidade do modelo ágil

\begin{tabular}{|c|c|c|c|c|}
\hline \multirow{4}{*}{ 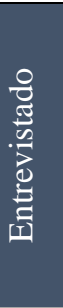 } & Unidade de Análise 8 & \multicolumn{3}{|l|}{ Comunicação } \\
\hline & Questão & \multicolumn{3}{|c|}{$\begin{array}{l}\text { Q17: A comunicação entre as equipes melhorou? Atualmente, como é a } \\
\text { comunicação interna da equipe e com as outras áreas? Como era } \\
\text { anteriormente? }\end{array}$} \\
\hline & Subunidade & \multicolumn{3}{|c|}{ Visibilidade do modelo ágil } \\
\hline & Mensagem principal & $\begin{array}{c}\text { Interpretação da } \\
\text { mensagem principal }\end{array}$ & Mensagem associada & $\begin{array}{c}\text { Interpretação da } \\
\text { mensagem associada }\end{array}$ \\
\hline E2 & $\begin{array}{l}\text { "Dar mais visibilidade } \\
\text { das entregas que a gente } \\
\text { faz... conseguindo fazer } \\
\text { os ritos de forma } \\
\text { cadenciada, e a gente } \\
\text { divulga isso para a } \\
\text { companhia, por que está } \\
\text { lá no Jira essas } \\
\text { informações acessíveis } \\
\text { para todo mundo". }\end{array}$ & $\begin{array}{l}\text { O modelo ágil traz } \\
\text { maior visibilidade por } \\
\text { meio dos ritos e da } \\
\text { divulgação de } \\
\text { informações para a } \\
\text { organização. }\end{array}$ & & \\
\hline E4 & $\begin{array}{l}\text { "Uma coisa importante } \\
\text { que a gente tem da } \\
\text { agilidade é... } \\
\text { visibilidade para o que o } \\
\text { time está fazendo... ou } \\
\text { também sobre } \\
\text { priorização...Tem um } \\
\text { monte de trabalho } \\
\text { invisível que era feito } \\
\text { dentro do time que a } \\
\text { gente conseguiu mapear, } \\
\text { reduzir automatizar". }\end{array}$ & $\begin{array}{l}\text { O modelo ágil traz } \\
\text { maior visibilidade por } \\
\text { meio de ritos e também } \\
\text { pela melhoria na } \\
\text { priorização das } \\
\text { atividades. }\end{array}$ & & \\
\hline E5 & $\begin{array}{l}\text { "Evidenciamos os } \\
\text { problemas... A agilidade } \\
\text { sempre faz isso, } \\
\text { evidencia problema... As } \\
\text { pessoas passam por um } \\
\text { processo de 'nossa, } \\
\text { quanta coisa errada tem } \\
\text { aqui"'. }\end{array}$ & $\begin{array}{l}\text { O modelo ágil traz } \\
\text { maior visibilidade às } \\
\text { atividades e aos } \\
\text { problemas das equipes. }\end{array}$ & & \\
\hline E7 & $\begin{array}{l}\text { "Tem muito mais } \\
\text { transparência... Porque } \\
\text { você fica o tempo todo } \\
\text { expondo o que você está } \\
\text { fazendo". }\end{array}$ & $\begin{array}{l}\text { O modelo ágil traz } \\
\text { maior visibilidade por } \\
\text { meio dos ritos. }\end{array}$ & $\begin{array}{l}\text { "Você pensa que é } \\
\text { solto, mas eu acho que } \\
\text { é muito pelo contrário, } \\
\text { agora você tem mais } \\
\text { controle". }\end{array}$ & $\begin{array}{l}\text { A percepção da } \\
\text { entrevistada foi de que o } \\
\text { modelo ágil traz maior } \\
\text { controle do que o } \\
\text { tradicional. }\end{array}$ \\
\hline
\end{tabular}

(Continua) 


\begin{tabular}{|c|c|c|c|c|}
\hline \multirow{4}{*}{ 定 } & Unidade de Análise 8 & \multicolumn{3}{|c|}{ Comunicação (Continuação) } \\
\hline & Questão & \multicolumn{3}{|c|}{$\begin{array}{l}\text { Q17: A comunicação entre as equipes melhorou? Atualmente, como é a } \\
\text { comunicação interna da equipe e com as outras áreas? Como era } \\
\text { anteriormente? }\end{array}$} \\
\hline & Subunidade & \multicolumn{3}{|c|}{ Visibilidade do modelo ágil } \\
\hline & Mensagem principal & $\begin{array}{l}\text { Interpretação da } \\
\text { mensagem principal }\end{array}$ & Mensagem associada & $\begin{array}{c}\text { Interpretação da } \\
\text { mensagem associada }\end{array}$ \\
\hline E10 & $\begin{array}{l}\text { "Deu esse problema, } \\
\text { porque temos um } \\
\text { problema... que acontece } \\
\text { isso mesmo. Aí ninguém } \\
\text { sabia... Então, tem umas } \\
\text { gambiarras que ninguém } \\
\text { nunca soube, e todo } \\
\text { mundo passou a saber". }\end{array}$ & $\begin{array}{l}\text { O modelo ágil traz } \\
\text { maior visibilidade às } \\
\text { atividades e aos } \\
\text { problemas das equipes. }\end{array}$ & & \\
\hline MP & \multicolumn{4}{|c|}{$\begin{array}{l}\text { O modelo ágil traz maior visibilidade ao trabalho das equipes, porém, também aos problemas ocorridos. } \\
\text { Por isso, pode haver resistência por parte das equipes por esta transparência, inclusive no nível } \\
\text { executivo. }\end{array}$} \\
\hline
\end{tabular}

Fonte: Quadro elaborado pela autora, com base nas entrevistas.

4.2.1.8 Integração com outras áreas - coleta de dados primários (UA 11)

Enquanto alguns processos ainda estiverem sendo realizados no modelo tradicional por diversas áreas, a implantação do modelo ágil apenas por parte da organização pode gerar impacto no tempo de execução dos projetos.

Quatro dos entrevistados (E1, E2, E5 e E6) mencionaram que a implantação do modelo ágil ocorreu apenas em parte da organização, geralmente nas áreas de Tecnologia e de Produtos. Os entrevistados E7, E9 e E10 relataram que a implantação do novo modelo ocorreu inicialmente na área de Digital e, posteriormente, foi expandida para a área de Tecnologia. O entrevistado E8 declarou que a transição foi realizada apenas na área de Tecnologia e não foi expandida para as demais (Quadro 21).

Quadro 21 - Análise da coleta de dados: Integração com outras áreas - Implantação nas demais áreas

\begin{tabular}{|c|c|c|c|c|}
\hline 0 & Unidade de Análise 11 & \multicolumn{3}{|l|}{ Integração com outras áreas } \\
\hline ర్ & Questão & \multicolumn{3}{|c|}{ Q22: O modelo ágil é utilizado por todas as áreas da organização? } \\
\hline$\sum_{0}^{2}$ & Subunidade & \multicolumn{3}{|c|}{ Implantação nas demais áreas } \\
\hline 壳 & Mensagem principal & $\begin{array}{l}\text { Interpretação da } \\
\text { mensagem principal }\end{array}$ & $\begin{array}{c}\text { Mensagem } \\
\text { associada }\end{array}$ & $\begin{array}{c}\text { Interpretação da } \\
\text { mensagem associada }\end{array}$ \\
\hline E1 & $\begin{array}{l}\text { "Falta gente suficiente para } \\
\text { dar continuidade à transição } \\
\text { dentro dessas áreas [cross]... } \\
\text { Deve estar no plano do } \\
\text { projeto de Transformação } \\
\text { Ágil". }\end{array}$ & $\begin{array}{l}\text { A implantação do } \\
\text { modelo ágil nas demais } \\
\text { áreas depende de mão de } \\
\text { obra. }\end{array}$ & & \\
\hline
\end{tabular}




\begin{tabular}{|c|c|c|c|c|}
\hline \multirow{4}{*}{ 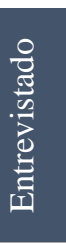 } & Unidade de Análise 11 & \multicolumn{3}{|c|}{ Integração com outras áreas (Continuação) } \\
\hline & Questão & \multicolumn{3}{|c|}{ Q22: O modelo ágil é utilizado por todas as áreas da organização? } \\
\hline & Subunidade & \multicolumn{3}{|c|}{ Implantação nas demais áreas } \\
\hline & Mensagem principal & $\begin{array}{c}\text { Interpretação da } \\
\text { mensagem principal }\end{array}$ & $\begin{array}{l}\text { Mensagem } \\
\text { associada }\end{array}$ & $\begin{array}{c}\text { Interpretação da } \\
\text { mensagem associada }\end{array}$ \\
\hline E2 & $\begin{array}{l}\text { "Os processos... precisam } \\
\text { melhorar ainda bastante... } \\
\text { integração com outros times } \\
\text { que não estão em squad. } \\
\text { Porque muitas vezes eu } \\
\text { preciso ter uma história que } \\
\text { eu priorizo, ela depende de } \\
\text { uma outra área que não está } \\
\text { alocada numa squad". }\end{array}$ & $\begin{array}{l}\text { A implantação do } \\
\text { modelo ágil nas demais } \\
\text { áreas traria maior } \\
\text { agilidade ao processo. }\end{array}$ & & \\
\hline E5 & $\begin{array}{l}\text { "O financeiro já teve algumas } \\
\text { iniciativas... compras } \\
\text { também... Várias áreas de } \\
\text { infraestrutura, TI, segurança, } \\
\text { já se mexeram". }\end{array}$ & $\begin{array}{l}\text { Existe uma iniciativa de } \\
\text { implantação do modelo } \\
\text { ágil nas demais áreas. }\end{array}$ & $\begin{array}{l}\text { “A nossa } \\
\text { participação não } \\
\text { está tão sólida. Eu } \\
\text { não sei se o trabalho } \\
\text { está evoluindo... A } \\
\text { gente não está } \\
\text { olhando para eles } \\
\text { por questões de } \\
\text { braço". }\end{array}$ & $\begin{array}{l}\text { A implantação do } \\
\text { modelo ágil nas demais } \\
\text { áreas depende de mão } \\
\text { de obra. }\end{array}$ \\
\hline E6 & $\begin{array}{l}\text { “Antes de a gente começar } \\
\text { com a transformação ágil, } \\
\text { eles [Infraestrutura e } \\
\text { Arquitetura] já estavam } \\
\text { tentando implantar Devops... } \\
\text { isso está colado no Scrum... } \\
\text { eles não faziam parte } \\
\text { integrante da squad... eram } \\
\text { acionados quando eu tivesse } \\
\text { alguma necessidade”. }\end{array}$ & $\begin{array}{l}\text { Existe uma iniciativa de } \\
\text { implantação do modelo } \\
\text { ágil nas demais áreas. }\end{array}$ & & \\
\hline E7 & $\begin{array}{l}\text { "O piloto tinha sido o } \\
\text { Digital... Eles tinham } \\
\text { adotado a agilidade na equipe } \\
\text { de TI, não estava ainda na } \\
\text { empresa inteira". }\end{array}$ & $\begin{array}{l}\text { A implantação do } \\
\text { modelo ágil iniciou na } \\
\text { área de Digital e } \\
\text { posteriormente na de } \\
\text { Tecnologia. }\end{array}$ & & \\
\hline E8 & $\begin{array}{l}\text { "Isso veio para tecnologia, } \\
\text { mas ficou ali como se fosse } \\
\text { uma necessidade só da } \\
\text { tecnologia e não como uma } \\
\text { oportunidade para as outras } \\
\text { áreas". }\end{array}$ & $\begin{array}{l}\text { A implantação do } \\
\text { modelo ágil ocorreu } \\
\text { apenas na área de } \\
\text { Tecnologia. }\end{array}$ & $\begin{array}{l}\text { "Eu entendo que } \\
\text { deveria mudar nas } \\
\text { outras áreas. Aliás, } \\
\text { deveria começar } \\
\text { como um todo, } \\
\text { sabe? Todo mundo } \\
\text { entender o } \\
\text { processo". }\end{array}$ & $\begin{array}{l}\text { A percepção da } \\
\text { entrevistada foi de que a } \\
\text { transição ágil deveria } \\
\text { permear todas as áreas } \\
\text { da organização. }\end{array}$ \\
\hline E9 & $\begin{array}{l}\text { "O mundo físico é } 100 \% \\
\text { cascata; e o mundo Digital é } \\
100 \% \text { ágil... Essa transição } \\
\text { do resto do banco e do resto } \\
\text { da tecnologia, ainda vai ser } \\
\text { complexa. }\end{array}$ & $\begin{array}{l}\text { A implantação do } \\
\text { modelo ágil iniciou na } \\
\text { área de Digital e } \\
\text { posteriormente na de } \\
\text { Tecnologia. }\end{array}$ & & \\
\hline E10 & $\begin{array}{l}\text { "Existe uma área da } \\
\text { companhia, o Digital, que faz } \\
\text { o site, e essa área é toda } \\
\text { ágill". }\end{array}$ & $\begin{array}{l}\text { A implantação do } \\
\text { modelo ágil iniciou na } \\
\text { área de Digital e } \\
\text { posteriormente na de } \\
\text { Tecnologia. }\end{array}$ & & \\
\hline
\end{tabular}




\begin{tabular}{|c|c|c|}
\hline 0 & Unidade de Análise 11 & Integração com outras áreas (Continuação) \\
\hline 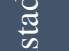 & Questão & Q22: O modelo ágil é utilizado por todas as áreas da organização? \\
\hline 8 & Subunidade & Implantação nas demais áreas \\
\hline $\mathbf{M}$ & \multicolumn{2}{|c|}{$\begin{array}{l}\text { A implantação do modelo ágil nas diversas áreas que participaram do projeto foi um fator chave para que } \\
\text { todo o processo fosse otimizado. Diversas organizações iniciaram a adoção em uma área de Digital ou de } \\
\text { Tecnologia, porém não expandiram para as demais, podendo gerar barreiras no andamento do projeto e } \\
\text { não colher todos os benefícios do novo modelo. }\end{array}$} \\
\hline
\end{tabular}

Fonte: Quadro elaborado pela autora, com base nas entrevistas.

\subsubsection{Desafios de Pessoas na Análise da Coleta de Dados Primários}

\subsubsection{Papéis e responsabilidades - coleta de dados primários (UA 13)}

A transição para o modelo ágil acarreta impacto nos papéis e nas responsabilidades dos membros da equipe, principalmente em relação aos soft skills. Por este motivo, a literatura recomenda que os treinamentos incluam não somente os novos processos ágeis em si, mas também as novas competências comportamentais que os membros das equipes devem assumir.

a) Novas responsabilidades

Seis dos entrevistados (E1, E2, E3, E5, E7 e E10) mencionaram que houve mudanças de papéis e de responsabilidades da equipe, o que exigiu um perfil multidisciplinar que muitos dos membros não tinham. Dois dos entrevistados (E3 e E10) mencionaram o aumento de responsabilidades do $\mathrm{PO}$ nos projetos ágeis, as quais faziam parte da gama de atuação do Gerente de Projetos na metodologia tradicional. Quatro dos entrevistados (E1, E2, E5 e E7) também mencionaram a mudança no papel do Scrum Master, agregando outras responsabilidades (soft skills e conhecimento do negócio) além do perfil técnico (Quadro 22). 
Quadro 22 - Análise da coleta de dados: Papéis e responsabilidade - Novas responsabilidades

\begin{tabular}{|c|c|c|c|c|}
\hline \multirow{4}{*}{ 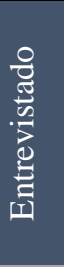 } & Unidade de Análise 13 & \multirow{2}{*}{\multicolumn{3}{|c|}{$\begin{array}{l}\text { Papéis e responsabilidades } \\
\text { Q16: Quais os impactos nas atividades e skills da equipe antes e depois da } \\
\text { transição? }\end{array}$}} \\
\hline & Questão & & & \\
\hline & Subunidade & \multicolumn{3}{|l|}{ Novas responsabilidades } \\
\hline & Mensagem principal & $\begin{array}{l}\text { Interpretação da } \\
\text { mensagem principal }\end{array}$ & Mensagem associada & $\begin{array}{l}\text { Interpretação da } \\
\text { mensagem associada }\end{array}$ \\
\hline E1 & $\begin{array}{l}\text { "As áreas de } \\
\text { desenvolvimento, por } \\
\text { exemplo, têm um maior } \\
\text { detalhamento do produto, } \\
\text { com a participação do } \\
\text { cliente ou dos PO's mais } \\
\text { de perto no projeto". }\end{array}$ & $\begin{array}{l}\text { Houve mudança no papel } \\
\text { da equipe de } \\
\text { desenvolvimento, } \\
\text { agregando outras } \\
\text { responsabilidades } \\
\text { (conhecimento do } \\
\text { negócio), além do perfil } \\
\text { técnico. }\end{array}$ & & \\
\hline E2 & $\begin{array}{l}\text { "O líder técnico, ele tem } \\
\text { que desenvolver não só a } \\
\text { habilidade técnica, mas a } \\
\text { habilidade também de } \\
\text { gestão indireta ... Já } \\
\text { numa squad você começa } \\
\text { a ter alguns soft skills que } \\
\text { precisam ser } \\
\text { desenvolvidos... Então } \\
\text { sim, tem uma mudança aí } \\
\text { drástica, com relação a } \\
\text { soft skills, } \\
\text { principalmente". }\end{array}$ & $\begin{array}{l}\text { Houve mudança no papel } \\
\text { do Scrum Master, } \\
\text { agregando outras } \\
\text { responsabilidades, soft } \\
\text { skills, além do perfil } \\
\text { técnico. }\end{array}$ & & \\
\hline E3 & $\begin{array}{l}\text { "A gente [PO] tem que } \\
\text { sair priorizando, } \\
\text { conversando com as } \\
\text { áreas, fechando plano, } \\
\text { estimando, tudo num } \\
\text { curto espaço de tempo... } \\
\text { Eu não tinha esse papel } \\
\text { antes... Agora eu acho } \\
\text { que a responsabilidade é } \\
\text { um pouco maior nesse } \\
\text { sentido. Se você não } \\
\text { define, se você não bate o } \\
\text { martelo, o projeto } \\
\text { também não anda". }\end{array}$ & $\begin{array}{l}\text { Houve aumento de } \\
\text { responsabilidades do PO } \\
\text { nos projetos ágeis, os } \\
\text { quais faziam parte da } \\
\text { gama de } \\
\text { responsabilidades do } \\
\text { Gerente de Projetos, na } \\
\text { metodologia tradicional. }\end{array}$ & & \\
\hline E5 & $\begin{array}{l}\text { "Todo mundo acha que é } \\
\text { fácil ser Scrum Master... } \\
\text { o Scrum Master não é de } \\
\text { processos, muitas vezes } \\
\text { ele é técnico". }\end{array}$ & $\begin{array}{l}\text { Dificuldade na transição } \\
\text { do papel de } \\
\text { desenvolvedor (perfil } \\
\text { técnico) para Scrum } \\
\text { Master (perfil de } \\
\text { processos). }\end{array}$ & & \\
\hline E7 & $\begin{array}{l}\text { "O Team Lead teve que } \\
\text { agregar algumas coisas } \\
\text { que não eram da } \\
\text { funcionalidade do Scrum } \\
\text { Master... essa parte do } \\
\text { RH, de controle de } \\
\text { férias". }\end{array}$ & $\begin{array}{l}\text { Houve mudança no papel } \\
\text { do Scrum Master, } \\
\text { agregando outras } \\
\text { responsabilidades }(\mathrm{RH}) \\
\text { além do perfil técnico. } \\
\text { Inclusive, ele passou a } \\
\text { ser chamado Team Lead. }\end{array}$ & & \\
\hline
\end{tabular}




\begin{tabular}{|c|c|c|c|c|}
\hline \multirow{4}{*}{ 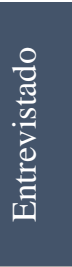 } & Unidade de Análise 13 & \multicolumn{3}{|c|}{ Papéis e responsabilidades (Continuação) } \\
\hline & Questão & \multicolumn{3}{|c|}{$\begin{array}{l}\text { Q16: Quais os impactos nas atividades e skills da equipe antes e depois da } \\
\text { transição? }\end{array}$} \\
\hline & Subunidade & \multicolumn{3}{|l|}{ Novas responsabilidades } \\
\hline & Mensagem principal & $\begin{array}{l}\text { Interpretação da } \\
\text { mensagem principal }\end{array}$ & Mensagem associada & $\begin{array}{l}\text { Interpretação da } \\
\text { mensagem associada }\end{array}$ \\
\hline E10 & $\begin{array}{l}\text { "Eles querem o poder de } \\
\text { gerenciar o projeto como } \\
\text { PO’s, isso seria a parte } \\
\text { mais importante e tal. } \\
\text { Mas, as } \\
\text { responsabilidades de PO } \\
\text { não querem a questão de } \\
\text { propor escopo, a questão } \\
\text { de trazer as partes } \\
\text { interessadas, de manter } \\
\text { todo mundo engajado". }\end{array}$ & $\begin{array}{l}\text { Houve aumento de } \\
\text { responsabilidades do PO } \\
\text { nos projetos ágeis, os } \\
\text { quais faziam parte da } \\
\text { gama do Gerente de } \\
\text { Projetos, na metodologia } \\
\text { tradicional. }\end{array}$ & & \\
\hline MP & \multicolumn{4}{|c|}{$\begin{array}{l}\text { Houve uma redistribuição de papéis internos das equipes. O PO assumiu responsabilidades que antes } \\
\text { cabiam ao Gerente de Projetos. O SM deve ter um perfil de liderança, além do técnico. } \\
\text { É importante que as equipes estejam preparadas para assumir estes novos papéis, por meio de } \\
\text { treinamentos ou do acompanhamento da equipe de transição. }\end{array}$} \\
\hline
\end{tabular}

Fonte: Quadro elaborado pela autora, com base nas entrevistas.

b) Perfil da equipe

A mudança do perfil da equipe em alguns casos resultou na substituição dos funcionários que não se adaptaram ao novo modelo. Dois dos entrevistados (E6 e E7) mencionaram que houve substituição de integrantes da equipe durante a transição ágil. Um dos entrevistados (E8) mencionou que o alto turnover da organização colaborou para a mudança de papéis dos funcionários. As pessoas que não tinham o perfil ágil foram sendo desligadas naturalmente da organização e os novos funcionários foram sendo contratados de acordo com o novo perfil demandado. Em um caso extremo, um dos entrevistados (E9) mencionou que houve a contratação externa de praticamente toda a equipe de Transformação Digital da organização, devido à falta de aderência dos funcionários existentes ao novo perfil. Neste caso, a empresa preferiu trazer o perfil ágil e arcar com a curva de aprendizado do negócio, ao invés de treinar no novo modelo os funcionários internos que já conheciam o negócio (Quadro 23). 
Quadro 23 - Análise da coleta de dados: Papéis e responsabilidades - Perfil da equipe

\begin{tabular}{|c|c|c|c|c|}
\hline \multirow{4}{*}{ 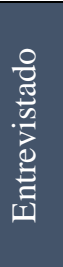 } & Unidade de Análise 13 & \multicolumn{3}{|l|}{ Papéis e responsabilidades } \\
\hline & Questão & \multicolumn{3}{|c|}{$\begin{array}{l}\text { Q16: Quais os impactos nas atividades e skills da equipe antes e depois da } \\
\text { transição? }\end{array}$} \\
\hline & Subunidade & \multicolumn{3}{|l|}{ Perfil da equipe } \\
\hline & Mensagem principal & $\begin{array}{l}\text { Interpretação da } \\
\text { mensagem principal }\end{array}$ & Mensagem associada & $\begin{array}{c}\text { Interpretação da } \\
\text { mensagem associada }\end{array}$ \\
\hline E6 & $\begin{array}{l}\text { "Algumas pessoas se } \\
\text { adaptaram e ficaram; } \\
\text { outras foram } \\
\text { substituídas porque não } \\
\text { se adaptaram". }\end{array}$ & $\begin{array}{l}\text { Houve substituição dos } \\
\text { funcionários que não se } \\
\text { adaptaram ao novo } \\
\text { modelo. }\end{array}$ & $\begin{array}{l}\text { “Principalmente da área } \\
\text { de negócios você não } \\
\text { consegue ir para o } \\
\text { mercado e substituir... } \\
\text { Você vai ter que dar } \\
\text { treinamento para os } \\
\text { 'caras', porque você vai } \\
\text { precisar reter o } \\
\text { conhecimento de } \\
\text { negócios dentro da } \\
\text { organização". }\end{array}$ & $\begin{array}{l}\text { Necessidade de reter o } \\
\text { conhecimento de } \\
\text { negócios dentro da } \\
\text { organização, treinando } \\
\text { as pessoas para o perfil } \\
\text { ágil. }\end{array}$ \\
\hline E7 & $\begin{array}{l}\text { "A gente controla } \\
\text { resultado. Você está } \\
\text { entregando, você está } \\
\text { entregando. Você não } \\
\text { está entregando, você } \\
\text { vai para o olho da rua". }\end{array}$ & $\begin{array}{l}\text { Houve substituição dos } \\
\text { funcionários que não se } \\
\text { adaptaram ao novo } \\
\text { modelo. }\end{array}$ & & \\
\hline E8 & $\begin{array}{l}\text { "Foram ganhando os } \\
\text { papéis... as pessoas } \\
\text { foram embora e vieram } \\
\text { os novos... Foi uma } \\
\text { transição um pouco } \\
\text { diferente... Foi turnover } \\
\text { mesmo". }\end{array}$ & $\begin{array}{l}\text { O alto turnover da } \\
\text { organização colaborou } \\
\text { para a mudança de } \\
\text { papéis. As pessoas que } \\
\text { não tinham o perfil ágil } \\
\text { foram sendo desligadas } \\
\text { da organização e os } \\
\text { novos funcionários } \\
\text { foram sendo contratados } \\
\text { de acordo com o novo } \\
\text { perfil demandado. }\end{array}$ & & \\
\hline E9 & $\begin{array}{l}\text { "A gente começou a } \\
\text { trazer todo mundo de } \\
\text { fora, porque ninguém de } \\
\text { dentro se adaptava, } \\
\text { ninguém tinha perfil... } \\
\text { Aí com a ciumeira que } \\
\text { gerou... a gente } \\
\text { começou a trazer } \\
\text { pessoas de dentro... Mas } \\
\text { te confesso que ainda é } \\
\text { mínimo, a grande } \\
\text { maioria veio de fora". }\end{array}$ & $\begin{array}{l}\text { Houve a contratação } \\
\text { externa de praticamente } \\
\text { toda a equipe de } \\
\text { Transformação Digital } \\
\text { da organização, devido à } \\
\text { falta de aderência dos } \\
\text { funcionários existentes } \\
\text { ao novo perfil. }\end{array}$ & & \\
\hline MP & \multicolumn{4}{|c|}{$\begin{array}{l}\text { A mudança no perfil da equipe resultou na substituição dos funcionários que não se adaptaram ao novo } \\
\text { modelo, ou ainda em um turnover natural na organização. Por este motivo, é imprescindível que o } \\
\text { processo de transição seja acompanhado pelo RH ou por uma equipe de Change Management. As } \\
\text { organizações devem investir na capacitação dos funcionários atuais quanto às novas competências } \\
\text { comportamentais e ao novo perfil multidisciplinar das equipes ágeis, ao invés de substituírem os } \\
\text { funcionários sem perfil, que não conhecem o negócio. }\end{array}$} \\
\hline
\end{tabular}

Fonte: Quadro elaborado pela autora, com base nas entrevistas. 
4.2.2.2 Tomada de decisão - coleta de dados primários (UA 14)

O modelo ágil requer uma mudança na tomada de decisão, em que toda a equipe do projeto passa a ter uma posição de protagonismo, mantendo o Gerente de Projetos apenas como um facilitador na resolução de impedimentos.

a) Papel do Gerente de Projetos

Quatro dos entrevistados (E1, E2, E5 e E6) informaram que o papel do Gerente de Projetos foi desmembrado entre o PO, o SM e os demais membros da equipe, passando a ter menos responsabilidades e podendo, inclusive, cuidar de uma quantidade maior de projetos, com um escopo menor de atuação em cada um deles. O entrevistado E5 mencionou que o papel do GP ainda não está claro depois da transição, devido à redução das suas responsabilidades. O entrevistado E3, por sua vez, informou que o GP foi substituído pelo AE, agregando funções de conhecimento do negócio, além das de planejamento (Quadro 24).

Quadro 24 - Análise da coleta de dados: Tomada de decisão - Papel do Gerente de Projetos

\begin{tabular}{|c|c|c|c|c|}
\hline \multirow{4}{*}{ 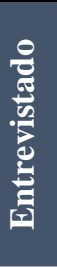 } & Unidade de Análise 14 & \multicolumn{3}{|l|}{ Tomada de decisão } \\
\hline & Questão & \multicolumn{3}{|c|}{$\begin{array}{l}\text { Q19: Houve mudança no papel de Gerente de Projetos antes e depois da } \\
\text { transição? Houve resistência? }\end{array}$} \\
\hline & Subunidade & \multicolumn{3}{|c|}{ Papel do Gerente de Projetos } \\
\hline & Mensagem principal & $\begin{array}{l}\text { Interpretação da } \\
\text { mensagem principal }\end{array}$ & Mensagem associada & $\begin{array}{c}\text { Interpretação da } \\
\text { mensagem associada }\end{array}$ \\
\hline E1 & $\begin{array}{l}\text { "Acho que para o GP } \\
\text { ficou mais light. H, hoje } \\
\text { temos menos atividades. } \\
\text { No modelo tradicional, o } \\
\text { GP controlava as } 10 \\
\text { áreas de conhecimento; } \\
\text { agora, a gestão está de } \\
\text { uma forma mais } \\
\text { simples". }\end{array}$ & $\begin{array}{l}\text { O papel do Gerente de } \\
\text { Projetos foi distribuído } \\
\text { entre o PO, o SM e os } \\
\text { demais membros da } \\
\text { equipe, passando a ter } \\
\text { menos responsabilidades. }\end{array}$ & $\begin{array}{l}\text { Os Gerentes de Projetos } \\
\text { receberam bem essa } \\
\text { transformação. }\end{array}$ & $\begin{array}{l}\text { A entrevistada informou } \\
\text { que não houve } \\
\text { resistência do GP. }\end{array}$ \\
\hline E2 & $\begin{array}{l}\text { "No papel de Gerente de } \\
\text { Projetos, a gente tem } \\
\text { uma gama de atuação } \\
\text { muito maior... Eu quero } \\
\text { saber o técnico. Eu, eu } \\
\text { controlo o custo. Eu, eu } \\
\text { vejo o risco... Num con- } \\
\text { texto de ágil, esses pa- } \\
\text { péis, essa responsabilida- } \\
\text { de é muito dividida com } \\
\text { o time como um todo, } \\
\text { porque existe essa ques- } \\
\text { tão do auto gerenciável". }\end{array}$ & $\begin{array}{l}\text { O papel do Gerente de } \\
\text { Projetos foi distribuído } \\
\text { entre o PO, o SM e os } \\
\text { demais membros da } \\
\text { equipe, passando a ter } \\
\text { menos responsabilidades. }\end{array}$ & $\begin{array}{l}\text { "Hoje, a minha área em } \\
\text { específico, ela tem três } \\
\text { papéis: ela tem um } \\
\text { papel de PMO mesmo; } \\
\text { ela tem um papel de } \\
\text { Agile Expert; e ela tem } \\
\text { um papel de Gerente de } \\
\text { Projetos. Vai depender } \\
\text { do tipo do projeto a } \\
\text { gente muda esse papel". }\end{array}$ & $\begin{array}{l}\text { Ainda existem } 3 \text { papéis } \\
\text { diferentes na } \\
\text { organização, que variam } \\
\text { de acordo com a } \\
\text { tipologia do projeto e o } \\
\text { escopo de atuação. }\end{array}$ \\
\hline
\end{tabular}




\begin{tabular}{|c|c|c|c|c|}
\hline \multirow{4}{*}{ 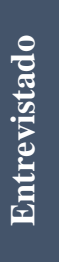 } & Unidade de Análise 14 & \multirow{2}{*}{\multicolumn{3}{|c|}{$\begin{array}{l}\text { Tomada de decisão (Continuação) } \\
\text { Q19: Houve mudança no papel de Gerente de Projetos antes e depois da } \\
\text { transição? Houve resistência? }\end{array}$}} \\
\hline & Questão & & & \\
\hline & Subunidade & \multicolumn{3}{|l|}{ Papel do Gerente de Projetos } \\
\hline & Mensagem principal & $\begin{array}{l}\text { Interpretação da } \\
\text { mensagem principal }\end{array}$ & Mensagem associada & $\begin{array}{l}\text { Interpretação da } \\
\text { mensagem associada }\end{array}$ \\
\hline E3 & $\begin{array}{l}\text { "Com o papel de AE, } \\
\text { primeiro ele começa a } \\
\text { olhar um pouco o } \\
\text { negócio, Ele não fica só } \\
\text { voltado ao } \\
\text { planejamento... mas, ele } \\
\text { teve que acrescentar } \\
\text { esses skills... Você tem } \\
\text { que saber do negócio } \\
\text { também, não fica só } \\
\text { preocupado com data". }\end{array}$ & $\begin{array}{l}\text { O GP foi substituído pelo } \\
\text { AE, que passou a agregar } \\
\text { mais funções de } \\
\text { conhecimento do } \\
\text { negócio, além do } \\
\text { planejamento já exigido } \\
\text { do GP. }\end{array}$ & & \\
\hline E5 & $\begin{array}{l}\text { "Existe uma falsa ideia } \\
\text { de que o PMO e o GP } \\
\text { têm que entender do } \\
\text { negócio... Meu skill não } \\
\text { é do negócio. Meu skill é } \\
\text { outro... Quando você cria } \\
\text { uma estrutura ágil, você } \\
\text { tem o PO. Então, você } \\
\text { não precisa de alguém } \\
\text { que entenda do negócio } \\
\text { além do PO". }\end{array}$ & $\begin{array}{l}\text { O papel do Gerente de } \\
\text { Projetos foi distribuído } \\
\text { entre o PO, o SM e os } \\
\text { demais membros da } \\
\text { equipe, passando a ter } \\
\text { menos responsabilidades. }\end{array}$ & $\begin{array}{l}\text { "Eu não conheço } \\
\text { nenhum lugar que a } \\
\text { gente entrou e que o GP } \\
\text { se encontrou. Para mim, } \\
\text { todos estão perdidos... } \\
\text { Eu vejo que eles só } \\
\text { estão marcando reunião } \\
\text { e organizando as coisas } \\
\text { para os diretores e } \\
\text { superintendentes... O } \\
\text { 'cara’ precisa fazer } \\
\text { status report, aí vira o } \\
\text { chato perguntando, por } \\
\text { quê?... não está no dia a } \\
\text { dia. Então eu vejo que o } \\
\text { GP perde a aderência } \\
\text { com a squad". }\end{array}$ & $\begin{array}{l}\text { O entrevistado ressaltou } \\
\text { que o papel do GP foi } \\
\text { reduzido depois da } \\
\text { transição ágil e ele } \\
\text { passou a realizar outras } \\
\text { atividades. }\end{array}$ \\
\hline E6 & $\begin{array}{l}\text { "Toda a parte financeira } \\
\text { era feita por um Gerente } \\
\text { de Projetos ou um } \\
\text { analista de projeto, mas } \\
\text { ele não tinha } \\
\text { interferência no dia a dia } \\
\text { da squad... Um GP } \\
\text { conseguia atender até } 6 \\
\text { ou } 7 \text { squads porque a } \\
\text { função dele era cuidar da } \\
\text { parte financeira". }\end{array}$ & $\begin{array}{l}\text { O papel do GP ficou } \\
\text { restrito ao controle do } \\
\text { orçamento do projeto, } \\
\text { sem atuação no escopo } \\
\text { ou no status do projeto. }\end{array}$ & & \\
\hline E7 & $\begin{array}{l}\text { "Quem resistiu mesmo } \\
\text { foram os Gerentes de } \\
\text { Projetos que não quise- } \\
\text { ram nem fazer o curso de } \\
\text { Scrum Master... Eu não } \\
\text { acredito nesse negócio, } \\
\text { aí está na rua hoje". }\end{array}$ & $\begin{array}{l}\text { Houve resistência dos } \\
\text { Gerentes de Projetos em } \\
\text { conhecerem o modelo } \\
\text { ágil, resultando na } \\
\text { substituição dos } \\
\text { funcionários. }\end{array}$ & & \\
\hline MP & $\begin{array}{l}\text { O papel do GP foi bastan } \\
\text { novos perfis de SM, de } \\
\text { resistência ao novo mode } \\
\text { Algumas organizações m } \\
\text { outras segregam os tipos } \\
\text { SM, PO ou AE. }\end{array}$ & $\begin{array}{l}\text { e reduzido em equipes ágei } \\
\text { O e da própria equipe de } \\
\text { lo e, em muitos casos, não } \\
\text { ntêm o papel de GP, porén } \\
\text { le projetos que requerem ur }\end{array}$ & $\begin{array}{l}\text { s, devido à distribuição } \\
\text { lesenvolvimento. Por is } \\
\text { se adaptaram, sendo } \\
\text { n com menos responsab } \\
\text { n GP, ou ainda mudam }\end{array}$ & $\begin{array}{l}\text { suas atividades entre os } \\
\text {, alguns GPs ofereceram } \\
\text { entualmente substituídos. } \\
\text { idades dentro do projeto; } \\
\text { ra um outro perfil, como }\end{array}$ \\
\hline
\end{tabular}

Fonte: Quadro elaborado pela autora, com base nas entrevistas. 
b) Autonomia da equipe

Em relação à autonomia da equipe, seis dos entrevistados (E2, E3, E5, E8 e E10) afirmaram que as equipes ágeis não possuíam autonomia para a tomada de decisão. $\mathrm{O}$ principal motivo, segundo três desses entrevistados (E5, E8 e E10), foi que a hierarquia da organização não delegava as responsabilidades para a equipe. Neste modelo, o PO não tem autonomia nem para decidir e nem para priorizar as funcionalidades dentro da sprint e depende do nível executivo para a tomada de decisão.

Outra dificuldade mencionada foi a concessão de autonomia para uma equipe nova, terceirizada, que não conhece o negócio da organização, principalmente no que tange ao perfil do seu negócio. O entrevistado E3 mencionou também que o PO possuía autonomia, porém a equipe ainda dependia muito da sua tomada de decisão dentro dos projetos, fazendo com que o PO virasse o "gargalo" do processo e acumulasse atividades e responsabilidades.

Em contrapartida, cinco dos entrevistados (E1, E4, E6, E7 e E9) informaram que a equipe do projeto passou a ter maior autonomia depois da transição para o modelo ágil, impactando positivamente sua motivação. Por fim, um dos entrevistados (E9) mencionou que mesmo a equipe tendo maior autonomia com o modelo ágil, ela ainda é nivelada na organização, principalmente quando comparado o nível estratégico com o operacional (Quadro 25).

Quadro 25 - Análise da coleta de dados: Tomada de decisão - Autonomia da equipe

\begin{tabular}{|c|c|c|c|c|}
\hline \multirow{4}{*}{ 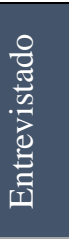 } & Unidade de Análise 14 & \multicolumn{3}{|l|}{ Tomada de decisão } \\
\hline & Questão & \multicolumn{3}{|c|}{ Q20: As equipes possuem autonomia para a tomada de decisão? } \\
\hline & Subunidade & \multicolumn{3}{|l|}{ Autonomia da equipe } \\
\hline & Mensagem principal & $\begin{array}{c}\text { Interpretação da } \\
\text { mensagem principal }\end{array}$ & Mensagem associada & $\begin{array}{c}\text { Interpretação da } \\
\text { mensagem associada }\end{array}$ \\
\hline E1 & $\begin{array}{l}\text { "O PO tem mais } \\
\text { autonomia para tomar } \\
\text { decisões sim. O } \\
\text { superintendente ou o } \\
\text { gerente não tem mais } \\
\text { que decidir sobre um } \\
\text { produto. Eles } \\
\text { conseguem decidir no } \\
\text { nível do analista". }\end{array}$ & $\begin{array}{l}\text { Existe autonomia do PO } \\
\text { para a tomada de } \\
\text { decisões. }\end{array}$ & $\begin{array}{l}\text { "E isso é bom porque } \\
\text { eles se sentem parte do } \\
\text { processo e ganham } \\
\text { autonomia". }\end{array}$ & $\begin{array}{l}\text { A autonomia impacta a } \\
\text { satisfação dos } \\
\text { funcionários. }\end{array}$ \\
\hline
\end{tabular}




\begin{tabular}{|c|c|c|c|c|}
\hline \multirow{4}{*}{ 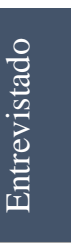 } & Unidade de Análise 14 & \multicolumn{3}{|c|}{ Tomada de decisão (Continuação) } \\
\hline & Questão & \multicolumn{3}{|c|}{ Q20: As equipes possuem autonomia para a tomada de decisão? } \\
\hline & Subunidade & \multicolumn{3}{|l|}{ Autonomia da equipe } \\
\hline & Mensagem principal & $\begin{array}{l}\text { Interpretação da } \\
\text { mensagem principal }\end{array}$ & Mensagem associada & $\begin{array}{l}\text { Interpretação da } \\
\text { mensagem associada }\end{array}$ \\
\hline $\mathbf{E 2}$ & $\begin{array}{l}\text { "Os processos da } \\
\text { Empresa B... Eu estou } \\
\text { mexendo no faturamento } \\
\text { das lojas... A gente está } \\
\text { passando por um } \\
\text { momento de um } \\
\text { turnover enorme na } \\
\text { companhia... As pessoas } \\
\text { são muito novas... elas } \\
\text { conhecem pouco o } \\
\text { negócio da Empresa... } \\
\text { Então é difícil você dar } \\
\text { autonomia para um time } \\
\text { que foi... recém } \\
\text { contratado pela } \\
\text { empresa... Somado a } \\
\text { isso, boa parte do time é } \\
\text { terceiro também". }\end{array}$ & $\begin{array}{l}\text { A entrevistada relatou a } \\
\text { dificuldade em dar } \\
\text { autonomia para a } \\
\text { equipe, devido ao tipo } \\
\text { do negócio, ao alto } \\
\text { turnover da organização } \\
\text { e ao modelo de } \\
\text { terceirização dos } \\
\text { funcionários. }\end{array}$ & & \\
\hline $\mathbf{E 3}$ & $\begin{array}{l}\text { "Eles não se sentem com } \\
\text { esse poder, então, tudo } \\
\text { tem que passar por mim. } \\
\text { Se eu não for lá e falar } \\
\text { OK, eu sinto que trava... } \\
\text { As coisas têm que fluir, } \\
\text { tem que dar empodera- } \\
\text { mento para o time para } \\
\text { ser ágil. Se ficar depen- } \\
\text { dendo de uma pessoa } \\
\text { não está ágil, porque a } \\
\text { pessoa vira o gargalo". }\end{array}$ & $\begin{array}{l}\text { A equipe ainda depende } \\
\text { do PO para a tomada de } \\
\text { decisões. }\end{array}$ & & \\
\hline $\mathbf{E 4}$ & $\begin{array}{l}\text { "Por mais que tenham } \\
\text { barreiras, às vezes, bom } \\
\text { eu consigo ir até aqui né, } \\
\text { por causa da gestão, mas } \\
\text { acho que a autonomia do } \\
\text { trabalho provavelmente } \\
\text { é o maior ganho que os } \\
\text { times tiveram". }\end{array}$ & $\begin{array}{l}\text { Existe autonomia da } \\
\text { equipe ágil para a } \\
\text { tomada de decisões, } \\
\text { apesar da estrutura } \\
\text { hierárquica da } \\
\text { organização. }\end{array}$ & $\begin{array}{l}\text { "Depois que começava } \\
\text { a fazer planning, daily, } \\
\text { retro, a satisfação do } \\
\text { time já aumentava". }\end{array}$ & $\begin{array}{l}\text { A autonomia impacta a } \\
\text { satisfação dos } \\
\text { funcionários. }\end{array}$ \\
\hline E5 & $\begin{array}{l}\text { "Eles têm um nível } \\
\text { limitado pela } \\
\text { característica da } \\
\text { companhia. Eles não têm } \\
\text { a visão estratégica do } \\
\text { negócio... A gente tem } \\
\text { uma empresa com } \\
\text { hierarquia, não adianta a } \\
\text { gente falar que acabou a } \\
\text { hierarquia, que o PO } \\
\text { decide... Para isso que } \\
\text { diretor existe". }\end{array}$ & $\begin{array}{l}\text { A estrutura hierárquica } \\
\text { da organização limita a } \\
\text { autonomia do PO. }\end{array}$ & & \\
\hline E6 & $\begin{array}{l}\text { "Dar autonomia, } \\
\text { davam... Mas... muitas } \\
\text { pessoas não queriam ter } \\
\text { autonomia". }\end{array}$ & $\begin{array}{l}\text { Existe autonomia da } \\
\text { equipe para a tomada de } \\
\text { decisões, porém nem } \\
\text { sempre é usufruída. }\end{array}$ & & (Continua) \\
\hline
\end{tabular}




\begin{tabular}{|c|c|c|c|c|}
\hline 0 & Unidade de Análise 14 & \multicolumn{3}{|c|}{ Tomada de decisão (Continuação) } \\
\hline 胥 & Questão & \multicolumn{3}{|c|}{ Q20: As equipes possuem autonomia para a tomada de decisão? } \\
\hline 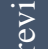 & Subunidade & \multicolumn{3}{|l|}{ Autonomia da equipe } \\
\hline$\underset{\text { 華 }}{\vec{E}}$ & Mensagem principal & $\begin{array}{c}\text { Interpretação da } \\
\text { mensagem principal }\end{array}$ & Mensagem associada & $\begin{array}{c}\text { Interpretação da } \\
\text { mensagem associada }\end{array}$ \\
\hline
\end{tabular}

E7 "Ele [o time] tem toda a A autonomia da equipe é autonomia na Planning... O PO traz priorizado o que ele precisa. E a equipe vai dizer 'consigo ou não consigo'".

E8 "O PO está na área de Tecnologia. Ele seria mais um escriba mesmo. Pega a demanda, passa para o time, mas não tem poder de decidir. Isso daí está com a área de produtos mesmo, eles que fazem a estratégia... Os executivos lá que priorizam o que eles entendem que é mais importante".

E9 "Eles têm autonomia para a tomada de decisão no nível mais micro... Quando a gente fala de macro experiência... está muito ainda no nível de Tribe Leader e no nível de diretor... aprova em diretoria e desce topdown para fazer".

E10 "Não, hoje não. Tem essa estrutura... da dentro da sprint, no que diz respeito à capacidade de entregas.

\section{O PO não tem} autonomia para a tomada de decisão. A priorização de funcionalidades ainda é realizada no nível executivo.

Product Manager... Os

PO's são funcionários da gerência de produtos, que está abaixo da diretoria de Inovação, e esses funcionários foram nomeados PO's porque eles estão seguindo ordens da Product Manager".

A autonomia da equipe é dentro da sprint, porém a estratégia ainda é decidida no nível executivo.

\section{As decisões são tomadas} no nível executivo.

.


4.2.2.3 Colaboração - coleta de dados primários (UA 15)

Há uma mudança drástica na colaboração entre os integrantes da equipe depois da transição para o modelo ágil, quando o ownership do projeto passa a ser compartilhado entre todos. Todos os entrevistados relataram que a colaboração melhorou consideravelmente depois da transformação ágil, sobretudo no interior na equipe. As dificuldades referiram-se sobretudo ao período de adaptação ao novo modelo e à colaboração entre as equipes (Quadro 26).

Quadro 26 - Análise da coleta de dados: Colaboração

\begin{tabular}{|c|c|c|c|c|}
\hline \multirow{3}{*}{ 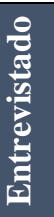 } & Unidade de Análise 15 & \multicolumn{3}{|l|}{ Colaboração } \\
\hline & Questão & \multicolumn{3}{|c|}{$\begin{array}{l}\text { Q18: A colaboração entre os membros da equipe melhorou? Os membros da } \\
\text { equipe sentem-se responsáveis pelo projeto (ownership)? }\end{array}$} \\
\hline & Mensagem principal & $\begin{array}{l}\text { Interpretação da } \\
\text { mensagem principal }\end{array}$ & Mensagem associada & $\begin{array}{c}\text { Interpretação da } \\
\text { mensagem associada }\end{array}$ \\
\hline E1 & $\begin{array}{l}\text { "Melhorou muito a } \\
\text { colaboração, no } \\
\text { assessment essa } \\
\text { melhoria é gritante". }\end{array}$ & $\begin{array}{l}\text { Houve melhoria na } \\
\text { colaboração depois da } \\
\text { transição para o modelo } \\
\text { ágil. Há métricas para } \\
\text { comprovar. }\end{array}$ & & \\
\hline E2 & $\begin{array}{l}\text { "Com certeza... Esse } \\
\text { senso de team building, } \\
\text { ele está muito já } \\
\text { enraizado". }\end{array}$ & $\begin{array}{l}\text { Houve melhoria na } \\
\text { colaboração depois da } \\
\text { transição para o modelo } \\
\text { ágil. }\end{array}$ & $\begin{array}{l}\text { "O BO tem um papel } \\
\text { muito bacana de } \\
\text { empoderamento da } \\
\text { squad, de atenção da } \\
\text { squad, porque quanto } \\
\text { mais o BO está presente } \\
\text { e ele dá voz à squad e } \\
\text { ele explica o porquê } \\
\text { tudo ali é importante, } \\
\text { mas a squad vê valor e } \\
\text { isso aumenta o } \\
\text { engajamento do time". }\end{array}$ & $\begin{array}{l}\text { O papel do Business } \\
\text { Owner (geralmente um } \\
\text { executivo) impacta o } \\
\text { empoderamento da } \\
\text { equipe. }\end{array}$ \\
\hline $\mathbf{E 3}$ & $\begin{array}{l}\text { "O time dentro daquele } \\
\text { projeto, daquele squad, } \\
\text { eles são super } \\
\text { colaborativos. Agora } \\
\text { quando é uma } \\
\text { necessidade de } \\
\text { colaboração fora do } \\
\text { squad, a gente sofre } \\
\text { mais com isso". }\end{array}$ & $\begin{array}{l}\text { A colaboração existe no } \\
\text { interior da própria } \\
\text { equipe, porém ainda é } \\
\text { um desafio entre as } \\
\text { equipes. }\end{array}$ & & \\
\hline $\mathbf{E 4}$ & $\begin{array}{l}\text { "No momento em que } \\
\text { você dá a missão para o } \\
\text { time... é } \\
\text { responsabilidade deles } \\
\text { garantir que aquilo vai } \\
\text { chegar no final. O gestor } \\
\text { está ali para facilitar, } \\
\text { para remover } \\
\text { obstáculos". }\end{array}$ & $\begin{array}{l}\text { Existe colaboração e } \\
\text { ownership dentro da } \\
\text { equipe. }\end{array}$ & & \\
\hline
\end{tabular}




\begin{tabular}{|c|c|c|c|c|}
\hline \multirow{3}{*}{ 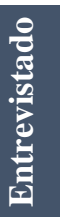 } & Unidade de Análise 15 & \multicolumn{3}{|l|}{ Colaboração (Continuação) } \\
\hline & Questão & \multicolumn{3}{|c|}{$\begin{array}{l}\text { Q18: A colaboração entre os membros da equipe melhorou? Os membros da } \\
\text { equipe sentem-se responsáveis pelo projeto (ownership)? }\end{array}$} \\
\hline & Mensagem principal & $\begin{array}{l}\text { Interpretação da } \\
\text { mensagem principal }\end{array}$ & Mensagem associada & $\begin{array}{l}\text { Interpretação da } \\
\text { mensagem associada }\end{array}$ \\
\hline $\mathbf{E 5}$ & $\begin{array}{l}\text { "Acho que tem } \\
\text { melhorado bastante... } \\
\text { Dentro de uma curva de } \\
\text { aprendizagem, a gente } \\
\text { está indo bem". }\end{array}$ & $\begin{array}{l}\text { Houve melhoria na } \\
\text { colaboração depois da } \\
\text { transição para o modelo } \\
\text { ágil. Porém ainda há } \\
\text { uma curva de } \\
\text { aprendizagem. }\end{array}$ & & \\
\hline E6 & $\begin{array}{l}\text { "Sim, melhorou... } \\
\text { diminuiu } 30 \% \text { dos } \\
\text { problemas que } \\
\text { chegavam em mim. Eu } \\
\text { consegui medir isso... as } \\
\text { pessoas começaram a } \\
\text { tentar resolver os } \\
\text { problemas". }\end{array}$ & $\begin{array}{l}\text { Houve melhoria na } \\
\text { colaboração depois da } \\
\text { transição para o modelo } \\
\text { ágil, com métricas para } \\
\text { comprovar. } \\
\text { Houve redução na } \\
\text { quantidade de } \\
\text { problemas que foram } \\
\text { escalados para o gestor } \\
\text { da equipe. }\end{array}$ & $\begin{array}{l}\text { "Nos primeiros seis } \\
\text { meses, a gente teve um } \\
\text { pouco de dificuldade } \\
\text { porque as pessoas ainda } \\
\text { não tinham clareza de } \\
\text { papel e de } \\
\text { responsabilidade... de } \\
\text { como colaborar uma } \\
\text { questão de } \\
\text { impedimento... Então, } \\
\text { no começo a gente teve } \\
\text { esse trabalho de } \\
\text { aculturamento. Teve } \\
\text { algumas pessoas } \\
\text { técnicas também que } \\
\text { não se adaptaram e } \\
\text { foram substituídas". }\end{array}$ & $\begin{array}{l}\text { Houve uma curva de } \\
\text { aprendizagem no início } \\
\text { da transição e também } \\
\text { impacto pela } \\
\text { substituição dos } \\
\text { membros da equipe. }\end{array}$ \\
\hline E7 & $\begin{array}{l}\text { "O time fala na } \\
\text { Planning: eu vou } \\
\text { entregar... Eles se } \\
\text { cobravam, cara, você vai } \\
\text { entregar? Você precisa } \\
\text { da minha ajuda?... Eles } \\
\text { tinham senso de } \\
\text { propriedade daquilo que } \\
\text { estava sendo feito e eles } \\
\text { queriam entregar } 100 \% \\
\text { da sprint". }\end{array}$ & $\begin{array}{l}\text { Existe colaboração e } \\
\text { ownership no interior da } \\
\text { equipe. }\end{array}$ & & \\
\hline E8 & $\begin{array}{l}\text { "Eu nunca trabalhei num } \\
\text { lugar em que as pessoas } \\
\text { fossem tão } \\
\text { colaborativas... Eu acho } \\
\text { que é institucional, } \\
\text { porque você pode ter um } \\
\text { problema e você pode ir } \\
\text { em qualquer mesa. Não } \\
\text { precisa falar com o } \\
\text { gestor, aquela coisa } \\
\text { hierárquica". }\end{array}$ & $\begin{array}{l}\text { Existe colaboração no } \\
\text { interior da equipe. }\end{array}$ & & \\
\hline E9 & $\begin{array}{l}\text { "Colaboração existe, ela } \\
\text { é bem forte... Uma vez } \\
\text { que uma depende da } \\
\text { outra, aí tem muita } \\
\text { colaboração". }\end{array}$ & $\begin{array}{l}\text { Existe colaboração no } \\
\text { interior da equipe. }\end{array}$ & & \\
\hline
\end{tabular}




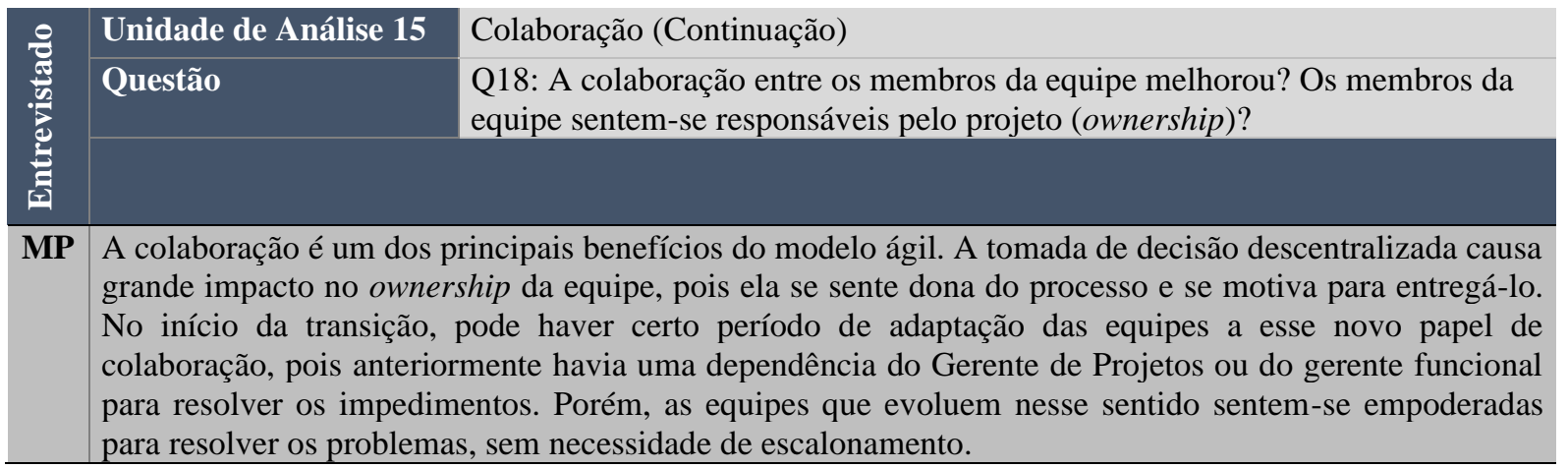

Fonte: Quadro elaborado pela autora, com base nas entrevistas.

\subsubsection{Resistência à Mudança - coleta de dados primários (UA 16)}

Como a maioria das mudanças é realizada no âmbito das pessoas, a equipe pode oferecer resistência e ter dificuldades para adaptação às práticas ágeis. A comunicação clara em relação ao processo de transição e ao novo modelo são recomendações da literatura para minimizar a resistência.

a) Resistência das equipes

Dentre os dez entrevistados, quatro (E1, E2, E5 e E8) relataram que houve baixa resistência das equipes durante a transição ágil. A maioria das equipes acreditava na transição ágil, apesar dos conflitos existentes entre as equipes durante o período de adaptação, ou da velocidade com que a organização gostaria que a transição ocorresse. Mas, todos mencionaram que é natural haver certa resistência por parte de algumas pessoas, principalmente quando se está alterando a forma como elas costumam trabalhar.

Quatro dos entrevistados (E3, E4, E6 e E10) mencionaram que houve resistência por parte de algumas equipes durante a transição ágil, principalmente pela de Produtos, que é uma das áreas mais impactadas. Os principais motivos foram o tempo de empresa e o acúmulo de responsabilidades depois da transição ágil.

Dois dos entrevistados (E7 e E9) informaram que houve resistência no início da transição, porém ela foi diminuindo gradativamente na medida em que as pessoas foram percebendo que o processo de transformação era uma realidade e que elas teriam que se adaptar para continuar na organização. Sempre há algumas pessoas mais resistentes que não se adaptam, mas a maioria passou a acreditar no novo modelo à medida que os resultados foram sendo apresentados (Quadro 27). 
Quadro 27 - Análise da coleta de dados: Resistência à mudança - Resistência das equipes

\begin{tabular}{|c|c|c|c|c|}
\hline \multirow{4}{*}{. } & Unidade de Análise 16 & \multicolumn{3}{|l|}{ Resistência à mudança } \\
\hline & Questão & \multicolumn{3}{|c|}{$\begin{array}{l}\text { Q12: A equipe e as demais áreas acreditavam na implantação do modelo ágil? } \\
\text { Houve aceitação ou resistência das áreas envolvidas? }\end{array}$} \\
\hline & Subunidade & \multicolumn{3}{|l|}{ Resistência das equipes } \\
\hline & Mensagem principal & $\begin{array}{l}\text { Interpretação da } \\
\text { mensagem principal }\end{array}$ & Mensagem associada & $\begin{array}{c}\text { Interpretação da } \\
\text { mensagem associada }\end{array}$ \\
\hline E1 & $\begin{array}{l}\text { "No geral, foi recebido } \\
\text { pela equipe de uma } \\
\text { forma positiva. Teve } \\
\text { pouca resistência e as } \\
\text { áreas abraçaram a } \\
\text { ideia". }\end{array}$ & $\begin{array}{l}\text { Houve baixa resistência } \\
\text { por parte das equipes } \\
\text { durante a transição ágil. }\end{array}$ & $\begin{array}{l}\text { "Claro que tiveram } \\
\text { exceções, mas foram } \\
\text { poucas, geralmente por } \\
\text { conflitos entre as áreas } \\
\text { de teste e DEV na } \\
\text { definição de papéis". }\end{array}$ & $\begin{array}{l}\text { Sempre há exceções quando } \\
\text { há mudanças na forma } \\
\text { como as pessoas costumam } \\
\text { trabalham. }\end{array}$ \\
\hline E2 & $\begin{array}{l}\text { "A gente acreditava que } \\
\text { ia dar certo, mas não no } \\
\text { ritmo que a empresa } \\
\text { queria que } \\
\text { acontecesse". }\end{array}$ & $\begin{array}{l}\text { Houve baixa resistência } \\
\text { por parte das equipes } \\
\text { durante a transição ágil, } \\
\text { relacionada à } \\
\text { velocidade da transição. } \\
\text { A equipe acreditou na } \\
\text { transição ágil. }\end{array}$ & $\begin{array}{l}\text { "No geral, sim. } \\
\text { Apoiavam, mas óbvio } \\
\text { que tem aquelas } \\
\text { pessoas que são mais } \\
\text { resistentes". }\end{array}$ & $\begin{array}{l}\text { Sempre há exceções quando } \\
\text { há mudanças na forma } \\
\text { como as pessoas costumam } \\
\text { trabalhar. }\end{array}$ \\
\hline $\mathbf{E 3}$ & $\begin{array}{l}\text { "Acho que é mais de } \\
\text { quem está ali na base } \\
\text { mesmo a resistência". }\end{array}$ & $\begin{array}{l}\text { Houve resistência } \\
\text { devido à prioridade das } \\
\text { demais áreas por não } \\
\text { estarem na transição } \\
\text { ágil. }\end{array}$ & $\begin{array}{l}\text { "Acho que no final } \\
\text { acreditavam... É } \\
\text { importante para a } \\
\text { empresa. Vamos vestir } \\
\text { a camisa e, então, } \\
\text { vamos em frente". }\end{array}$ & $\begin{array}{l}\text { A equipe acreditou na } \\
\text { transição ágil. }\end{array}$ \\
\hline E4 & $\begin{array}{l}\text { "Teve bastante } \\
\text { resistência, porque as } \\
\text { pessoas lá às vezes } \\
\text { tinham a minha idade } \\
\text { de experiência de } \\
\text { trabalho". }\end{array}$ & $\begin{array}{l}\text { Houve resistência, } \\
\text { principalmente por } \\
\text { parte dos funcionários } \\
\text { com maior tempo de } \\
\text { experiência. }\end{array}$ & $\begin{array}{l}\text { "Eu era muito } \\
\text { questionada quanto a } \\
\text { ‘quem você pensa que } \\
\text { é para vir aqui falar } \\
\text { como eu devo fazer o } \\
\text { meu trabalho?" }\end{array}$ & $\begin{array}{l}\text { Dificuldade da equipe em } \\
\text { aceitar mudanças na forma } \\
\text { como deve trabalhar. }\end{array}$ \\
\hline E5 & $\begin{array}{l}\text { "Eu acho que a maior } \\
\text { parte tem uma } \\
\text { expectativa positiva... } \\
\text { mas, acho que a } \\
\text { resistência tá dentro da } \\
\text { conta. Ela é baixa e } \\
\text { normal". }\end{array}$ & $\begin{array}{l}\text { Houve baixa resistência } \\
\text { das equipes durante a } \\
\text { transição ágil. }\end{array}$ & $\begin{array}{l}\text { "Sempre tem uma } \\
\text { galerinha que acha que } \\
\text { você está mexendo, } \\
\text { que vai atrapalhar } \\
\text { porque muda o modo } \\
\text { de trabalho das } \\
\text { pessoas". }\end{array}$ & $\begin{array}{l}\text { Sempre há exceções quando } \\
\text { há mudanças na forma } \\
\text { como as pessoas costumam } \\
\text { trabalhar. }\end{array}$ \\
\hline E6 & $\begin{array}{l}\text { "A área de produtos, } \\
\text { que é a mais } \\
\text { beneficiada do } \\
\text { processo, foi uma das } \\
\text { áreas que mais teve } \\
\text { dificuldade de lidar com } \\
\text { esse novo jeito de } \\
\text { executar, porque a área } \\
\text { de produtos passa a ter } \\
\text { uma responsabilidade } \\
\text { muito grande. Ela é } \\
\text { dona do produto e o } \\
\text { time é autossuficiente". }\end{array}$ & $\begin{array}{l}\text { A maior resistência foi } \\
\text { por parte da área de } \\
\text { Produtos, devido à } \\
\text { responsabilidade } \\
\text { adicional decorrente do } \\
\text { modelo ágil. }\end{array}$ & & \\
\hline
\end{tabular}

(Continua) 


\begin{tabular}{|c|c|c|c|c|}
\hline \multirow{4}{*}{ 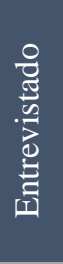 } & Unidade de Análise 16 & \multicolumn{3}{|c|}{ Resistência à mudança (Continuação) } \\
\hline & Questão & \multicolumn{3}{|c|}{$\begin{array}{l}\text { Q12: A equipe e as demais áreas acreditavam na implantação do modelo ágil? } \\
\text { Houve aceitação ou resistência das áreas envolvidas? }\end{array}$} \\
\hline & Subunidade & \multicolumn{3}{|l|}{ Resistência das equipes } \\
\hline & Mensagem principal & $\begin{array}{l}\text { Interpretação da } \\
\text { mensagem principal }\end{array}$ & Mensagem associada & $\begin{array}{l}\text { Interpretação da } \\
\text { mensagem associada }\end{array}$ \\
\hline E7 & $\begin{array}{l}\text { "No começo, ninguém } \\
\text { queria, depois, todo } \\
\text { mundo queria... Virou } \\
\text { aquele negócio: 'eu } \\
\text { também preciso estar } \\
\text { nesse movimento } \\
\text { porque o mundo inteiro } \\
\text { está se movimentando e } \\
\text { eu não estou'. Então, de } \\
\text { cara, todo mundo } \\
\text { resistiu. Mas depois, } \\
\text { passados uns } 2,3 \\
\text { meses, todo mundo } \\
\text { queria virar ágil". }\end{array}$ & $\begin{array}{l}\text { Houve mudança das } \\
\text { equipes, que no início } \\
\text { eram mais resistentes ao } \\
\text { novo modelo, mas } \\
\text { depois perceberam que } \\
\text { teriam que se } \\
\text { transformar. }\end{array}$ & $\begin{array}{l}\text { "Não todo mundo, mas } \\
\text { a maioria, né, porque } \\
\text { sempre tem uns mais } \\
\text { resistentes". }\end{array}$ & $\begin{array}{l}\text { Sempre há exceções quando } \\
\text { há mudança na forma como } \\
\text { as pessoas costumam } \\
\text { trabalhar. }\end{array}$ \\
\hline E8 & $\begin{array}{l}\text { "De tecnologia, não... } \\
\text { porque todo mundo já } \\
\text { conhecia. E acredito } \\
\text { que outras áreas } \\
\text { também não, as pessoas } \\
\text { não foram resistentes". }\end{array}$ & $\begin{array}{l}\text { Houve baixa resistência } \\
\text { das equipes durante a } \\
\text { transição ágil, devido } \\
\text { ao conhecimento do } \\
\text { novo processo } \\
\text { adquirido } \\
\text { anteriormente. }\end{array}$ & & \\
\hline E9 & $\begin{array}{l}\text { "Resistência é muito } \\
\text { baixa. A resistência } \\
\text { maior, por incrível que } \\
\text { pareça, é na área de } \\
\text { tecnologia do legado, } \\
\text { por um motivo simples. } \\
\text { As pessoas são um } \\
\text { bando de dinossauros, } \\
\text { que estão lá há } 20 \text { anos } \\
\text { e... morrem de medo de } \\
\text { perder o emprego". }\end{array}$ & $\begin{array}{l}\text { Existe resistência } \\
\text { principalmente por } \\
\text { parte dos funcionários } \\
\text { com maior tempo de } \\
\text { experiência. }\end{array}$ & $\begin{array}{l}\text { "Agora as áreas } \\
\text { realmente acreditam na } \\
\text { agilidade... No } \\
\text { começo não, mas agora } \\
\text { eles acreditam... } \\
\text { Melhorou porque as } \\
\text { pessoas passaram a } \\
\text { acreditar e quebrou } \\
\text { muito a resistência... A } \\
\text { dificuldade era a } \\
\text { resistência e a crença } \\
\text { no modelo". }\end{array}$ & $\begin{array}{l}\text { Houve mudança das } \\
\text { equipes, que no início eram } \\
\text { mais resistentes, mas } \\
\text { depois, passaram a acreditar } \\
\text { no modelo ágil. }\end{array}$ \\
\hline E10 & $\begin{array}{l}\text { "O problema está na } \\
\text { cadeia de stakeholders } \\
\text { de produtos". }\end{array}$ & $\begin{array}{l}\text { A maior resistência foi } \\
\text { por parte da área de } \\
\text { Produtos, que não } \\
\text { acreditava no modelo } \\
\text { ágil. }\end{array}$ & & \\
\hline MP & $\begin{array}{l}\text { A resistência, principaln } \\
\text { pessoas quanto ao novo } \\
\text { Como o modelo ágil in } \\
\text { funcionários mais antigo } \\
\text { estão acostumados, pois }\end{array}$ & $\begin{array}{l}\text { ente no início da transiçã } \\
\text { todelo ou ao aumento de } \\
\text { pacta os processos e as } \\
\text {, que não aceitam mudan } \\
\text { icreditam que funciona be }\end{array}$ & $\begin{array}{l}\text { estava frequentemente } \\
\text { sponsabilidades e de ati } \\
\text { essoas, há resistência } \\
\text { s no modo como costun } \\
\text {. }\end{array}$ & $\begin{array}{l}\text { relacionada à descrença das } \\
\text { idades das equipes. } \\
\text { incipalmente por parte dos } \\
\text { am trabalhar e com o qual já }\end{array}$ \\
\hline
\end{tabular}

Fonte: Quadro elaborado pela autora, com base nas entrevistas.

b) Comunicação dos objetivos da transição

A comunicação clara para todas as equipes quanto aos objetivos da transição e a transparência do processo é um dos principais fatores para reduzir a resistência das mesmas. 
Seis dos entrevistados (E1, E2, E4, E5, E6 e E7) relataram que houve uma comunicação clara por parte da organização, por meio de vídeos, treinamentos presenciais ou acompanhamento da equipe de transição. O entrevistado E5 informou que houve comunicação quanto à transição, porém apenas para as áreas impactadas.

Três dos entrevistados (E3, E8 e E9) informaram que não houve comunicação por parte da organização quanto à transição ágil. O entrevistado E9 informou que, no início, não houve comunicação. Quando houve a troca do presidente da organização e foi criada uma área responsável pela comunicação, começou a haver esta movimentação. $\mathrm{O}$ apoio da presidência é mencionado como um ponto relevante para a quebra de resistência na transformação ágil.

A importância do cascateamento da informação, desde o nível estratégico até o nível operacional, também foi mencionada pelos entrevistados E3 e E4, como uma forma de engajamento das equipes. Outro fator chave para a comunicação da transição é a divulgação das conquistas e realizações para toda a organização. A comunicação quanto ao processo de treinamento e às equipes que já participaram da transição aumenta o senso de pertencimento das equipes e promove o engajamento (Quadro 28).

Quadro 28 - Análise da coleta de dados: Resistência à mudança - Comunicação dos objetivos da transição

\begin{tabular}{|c|c|c|c|c|}
\hline \multirow{4}{*}{ 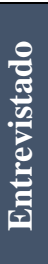 } & Unidade de Análise $\mathbf{1 6}$ & \multicolumn{3}{|l|}{ Resistência à mudança } \\
\hline & Questão & \multicolumn{3}{|c|}{$\begin{array}{l}\text { Q8: A gestão da empresa informou sobre os objetivos da mudança para o } \\
\text { modelo ágil? Houve transparência durante o processo de transição? }\end{array}$} \\
\hline & Subunidade & \multicolumn{3}{|c|}{ Comunicação dos objetivos da transição } \\
\hline & Mensagem principal & $\begin{array}{l}\text { Interpretação da } \\
\text { mensagem principal }\end{array}$ & Mensagem associada & $\begin{array}{l}\text { Interpretação da } \\
\text { mensagem associada }\end{array}$ \\
\hline E1 & $\begin{array}{l}\text { "Teve transparência } \\
\text { sobre o processo e sobre } \\
\text { os objetivos também. } \\
\text { Estava claro para todos } \\
\text { os funcionários qual era } \\
\text { o objetivo da empresa... } \\
\text { Foram feitos } \\
\text { treinamentos, } \\
\text { workshops, divulgações } \\
\text { na intranet, vídeos". }\end{array}$ & $\begin{array}{l}\text { Houve comunicação } \\
\text { quanto ao processo e } \\
\text { quanto aos objetivos da } \\
\text { transição. }\end{array}$ & & \\
\hline E2 & $\begin{array}{l}\text { "Foi comunicado para a } \\
\text { empresa como um todo, } \\
\text { inclusive tinha até } \\
\text { banners nas TV's, no } \\
\text { café, falando da } \\
\text { transformação digital da } \\
\text { empresa". }\end{array}$ & $\begin{array}{l}\text { Houve comunicação } \\
\text { quanto ao processo de } \\
\text { transição. }\end{array}$ & & \\
\hline
\end{tabular}

(Continua) 


\begin{tabular}{|c|c|c|c|c|}
\hline \multirow{4}{*}{ 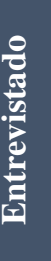 } & Unidade de Análise 16 & \multicolumn{3}{|c|}{ Resistência à mudança (Continuação) } \\
\hline & Questão & \multicolumn{3}{|c|}{$\begin{array}{l}\text { Q8: A gestão da empresa informou sobre os objetivos da mudança para o } \\
\text { modelo ágil? Houve transparência durante o processo de transição? }\end{array}$} \\
\hline & Subunidade & \multicolumn{3}{|c|}{ Comunicação dos objetivos da transição } \\
\hline & Mensagem principal & $\begin{array}{l}\text { Interpretação da } \\
\text { mensagem principal }\end{array}$ & Mensagem associada & $\begin{array}{l}\text { Interpretação da } \\
\text { mensagem associada }\end{array}$ \\
\hline $\mathbf{E 3}$ & $\begin{array}{l}\text { "Tem o fórum do } \\
\text { Digital... Acho que cada } \\
\text { área tem um } \\
\text { representante, mas pelo } \\
\text { menos na minha área } \\
\text { isso não é cascateado". }\end{array}$ & $\begin{array}{l}\text { A comunicação quanto à } \\
\text { transição não chegou em } \\
\text { todos os níveis da } \\
\text { organização. A } \\
\text { entrevistada ressaltou a } \\
\text { importância do } \\
\text { cascateamento das } \\
\text { informações pela gestão. }\end{array}$ & & \\
\hline E4 & $\begin{array}{l}\text { "Tinha uma } \\
\text { comunicação de que } \\
\text { tinha dado início e } \\
\text { depois tinha como se } \\
\text { fosse um termômetro, } \\
\text { que ia sendo } \\
\text { comunicado, conforme } \\
\text { os times iam sendo } \\
\text { formados". }\end{array}$ & $\begin{array}{l}\text { Houve comunicação } \\
\text { quanto ao status da } \\
\text { transição e à formação } \\
\text { dos times. }\end{array}$ & $\begin{array}{l}\text { "Se você não tem a } \\
\text { média gestão engajada } \\
\text { vira um telefone sem fio. } \\
\text { Uma parte recebe a } \\
\text { mensagem e uma parte } \\
\text { não... Faltou uma forma } \\
\text { de engajar todos os } \\
\text { níveis, não deixar a } \\
\text { comunicação se perder } \\
\text { no meio do caminho". }\end{array}$ & $\begin{array}{l}\text { A entrevistada ressaltou } \\
\text { a importância do } \\
\text { cascateamento das } \\
\text { informações na } \\
\text { organização. }\end{array}$ \\
\hline E5 & $\begin{array}{l}\text { "Ainda existe uma } \\
\text { resistência no sentido de } \\
\text { 'vamos tombar a } \\
\text { empresa inteira ou não'. } \\
\text { A gente fez divulgações } \\
\text { para as áreas que } \\
\text { estavam sendo } \\
\text { tombadas, e não para a } \\
\text { empresa inteira". }\end{array}$ & $\begin{array}{l}\text { Houve comunicação } \\
\text { quanto ao processo de } \\
\text { transição, porém apenas } \\
\text { para as áreas que } \\
\text { estavam sendo } \\
\text { transformadas. }\end{array}$ & & \\
\hline E6 & $\begin{array}{l}\text { "A comunicação do } \\
\text { projeto, da importância, } \\
\text { do porquê, ela foi } \\
\text { excelente. E tinha que } \\
\text { ser excelente, até porque } \\
\text { o próprio presidente da } \\
\text { empresa é um } \\
\text { entusiasta. Então, ele } \\
\text { fazia muito essa } \\
\text { comunicação } \\
\text { pessoalmente também". }\end{array}$ & $\begin{array}{l}\text { Houve comunicação } \\
\text { quanto ao processo e } \\
\text { aos objetivos da } \\
\text { transição, inclusive pelo } \\
\text { presidente que era o } \\
\text { sponsor desta } \\
\text { transformação. }\end{array}$ & & \\
\hline E7 & $\begin{array}{l}\text { "Eles [consultoria] } \\
\text { chamavam os Team } \\
\text { Leads antes para } \\
\text { conversar como iria } \\
\text { fazer para pegar tudo o } \\
\text { que estava no [modelo] } \\
\text { cascata para virar para o } \\
\text { ágil". }\end{array}$ & $\begin{array}{l}\text { Houve comunicação } \\
\text { quanto ao processo pela } \\
\text { consultoria contratada, a } \\
\text { cada nova área que era } \\
\text { transformada. }\end{array}$ & $\begin{array}{l}\text { "Toda vez que tinha uma } \\
\text { virada do [modelo] } \\
\text { cascata para o ágil eles } \\
\text { publicavam e mostravam } \\
\text { foto de todo mundo } \\
\text { comemorando... E aí } \\
\text { fortaleceu mesmo". }\end{array}$ & $\begin{array}{l}\text { A divulgação dos } \\
\text { resultados da transição e } \\
\text { a comemoração do novo } \\
\text { modelo foram } \\
\text { mencionados como } \\
\text { fatores de redução da } \\
\text { resistência. }\end{array}$ \\
\hline E8 & $\begin{array}{l}\text { "Não, não teve... Foi } \\
\text { uma transição do tipo: } \\
\text { 'vamos fazer assim } \\
\text { agora'. Não teve uma } \\
\text { estruturação". }\end{array}$ & $\begin{array}{l}\text { Não houve comunicação } \\
\text { quanto à transição na } \\
\text { organização. Foi uma } \\
\text { decisão da área de } \\
\text { Tecnologia. }\end{array}$ & & \\
\hline
\end{tabular}

(Continua) 


\begin{tabular}{|c|c|c|c|c|}
\hline \multirow{4}{*}{ 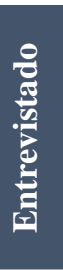 } & Unidade de Análise 16 & \multicolumn{3}{|c|}{ Resistência à mudança (Continuação) } \\
\hline & Questão & \multicolumn{3}{|c|}{$\begin{array}{l}\text { Q8: A gestão da empresa informou sobre os objetivos da mudança para o } \\
\text { modelo ágil? Houve transparência durante o processo de transição? }\end{array}$} \\
\hline & Subunidade & \multicolumn{3}{|c|}{ Comunicação dos objetivos da transição } \\
\hline & Mensagem principal & $\begin{array}{l}\text { Interpretação da } \\
\text { mensagem principal }\end{array}$ & Mensagem associada & $\begin{array}{l}\text { Interpretação da } \\
\text { mensagem associada }\end{array}$ \\
\hline E9 & $\begin{array}{l}\text { "Não, de jeito nenhum. } \\
\text { O presidente falava de } \\
\text { transformação digital, } \\
\text { mas o negócio era } \\
\text { totalmente etéreo... } \\
\text { Quando o novo } \\
\text { presidente entrou... a } \\
\text { gente mudou o } \\
\text { modelo... Começou a } \\
\text { fazer um trabalho muito } \\
\text { forte de comunicação, } \\
\text { de divulgação e } \\
\text { envolvimento de várias } \\
\text { áreas... Então começou } \\
\text { a comunicar muito } \\
\text { melhor esse ano. No ano } \\
\text { passado não tinha nada } \\
\text { disso". }\end{array}$ & $\begin{array}{l}\text { Não houve comunicação } \\
\text { no início da transição, } \\
\text { apenas quando ocorreu a } \\
\text { mudança na presidência } \\
\text { da organização. }\end{array}$ & $\begin{array}{l}\text { "Diretoria nova de } \\
\text { Transformação } \\
\text { Organizacional... tem } \\
\text { embaixo } 3 \\
\text { superintendências: uma } \\
\text { de Capital Humano, que } \\
\text { é RH, outra de Cultura, e } \\
\text { outra de Governança } \\
\text { ágil. Essa de } \\
\text { Governança... são } \\
\text { responsáveis por uma } \\
\text { série de projetos, } \\
\text { inclusive comunicação } \\
\text { para a empresa do que é } \\
\text { Digital". }\end{array}$ & $\begin{array}{l}\text { Foi criada uma nova } \\
\text { diretoria responsável } \\
\text { pela Transformação, } \\
\text { com uma } \\
\text { superintendência } \\
\text { responsável pela } \\
\text { comunicação do novo } \\
\text { processo. }\end{array}$ \\
\hline MP & \multicolumn{4}{|c|}{$\begin{array}{l}\text { A comunicação dos objetivos da transição para todos os níveis da organização é considerada essencial } \\
\text { para que todos os funcionários se sintam parte do processo e entendam os benefícios do novo modelo, } \\
\text { atuando, então, como um redutor da resistência à mudança. A comunicação também é eficiente na } \\
\text { divulgação dos resultados da transição, aumentando o senso de pertencimento e o engajamento das } \\
\text { equipes. Deve ocorrer sempre de forma estruturada, de preferência com o apoio da alta gestão. }\end{array}$} \\
\hline
\end{tabular}

Fonte: Quadro elaborado pela autora, com base nas entrevistas.

\section{c) Retorno ao modelo anterior}

Um ponto destacado por dois dos entrevistados (E3 e E4) foi a percepção por parte da organização, inclusive da gestão, de que voltariam ao modelo de trabalho anterior, após concluída a transição (Quadro 29). 
Quadro 29 - Análise da coleta de dados: Resistência à mudança - Retorno ao modelo anterior

\begin{tabular}{|c|c|c|c|c|}
\hline \multirow{4}{*}{ 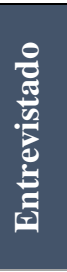 } & Unidade de Análise 16 & \multicolumn{3}{|l|}{ Resistência à mudança } \\
\hline & Questão & \multicolumn{3}{|c|}{$\begin{array}{l}\text { Q8: A gestão da empresa informou sobre os objetivos da mudança para o } \\
\text { modelo ágil? Houve transparência durante o processo de transição? }\end{array}$} \\
\hline & Subunidade & \multicolumn{3}{|c|}{ Retorno ao modelo anterior } \\
\hline & Mensagem principal & $\begin{array}{l}\text { Interpretação da } \\
\text { mensagem principal }\end{array}$ & Mensagem associada & $\begin{array}{l}\text { Interpretação da } \\
\text { mensagem associada }\end{array}$ \\
\hline $\mathbf{E 3}$ & $\begin{array}{l}\text { "Eu acho que vai ter que } \\
\text { adaptar, é um caminho } \\
\text { sem volta. Não tem } \\
\text { como falar 'vamos } \\
\text { voltar ao que era antes', } \\
\text { isso não existe. É isso } \\
\text { que eu falo para as } \\
\text { pessoas: é esse o } \\
\text { movimento e não } \\
\text { adianta falar 'que } \\
\text { saudade da empresa de } \\
\text { antes'. Não existe este } \\
\text { cenário de antes". }\end{array}$ & $\begin{array}{l}\text { Existe a percepção da } \\
\text { organização de que } \\
\text { voltaria ao modelo de } \\
\text { trabalho anterior após } \\
\text { concluída a transição. }\end{array}$ & & \\
\hline $\mathbf{E} 4$ & $\begin{array}{l}\text { "Eu fazia todo o trabalho } \\
\text { de Agile Coach, mas a } \\
\text { 'galera' falava: 'quando } \\
\text { terminar o teu trabalho } \\
\text { de treinar a galera você } \\
\text { pode voltar a fazer o que } \\
\text { você fazia antes', o que } \\
\text { não fazia nenhum } \\
\text { sentido. E eles falavam } \\
\text { como se fosse algo que } \\
\text { fosse acabar, e até hoje } \\
\text { não acabou, então é bem } \\
\text { complicado". }\end{array}$ & $\begin{array}{l}\text { Existe a percepção da } \\
\text { organização de que } \\
\text { voltaria ao modelo de } \\
\text { trabalho anterior após } \\
\text { concluída a transição. }\end{array}$ & & \\
\hline MP & \multicolumn{4}{|c|}{$\begin{array}{l}\text { A percepção de que, após o término da transição, os processos retomariam ao modelo anterior foi um } \\
\text { fator de grande resistência e refletiu na descrença quanto ao novo modelo, ressaltando a necessidade de } \\
\text { comunicação, treinamento e acompanhamento das equipes pela área responsável pela transição e pelo } \\
\text { apoio de Change Management. }\end{array}$} \\
\hline
\end{tabular}

Fonte: Quadro elaborado pela autora, com base nas entrevistas.

\subsubsection{Cliente dedicado - coleta de dados primários (UA 17)}

Embora na entrevista, não tenha havido nenhuma questão específica em relação à alocação de equipes dedicadas nos projetos, a dedicação do cliente foi abordada por quatro dos entrevistados (E1, E2, E3 e E6) quando questionados sobre a resistência das equipes. Eles relataram que houve dificuldades na alocação das equipes de negócio, pois as mesmas ainda estavam divididas entre a operação e os projetos, gerando atrasos na priorização e na tomada de decisão dos projetos (Quadro 30). 
Quadro 30 - Análise da coleta de dados: Cliente dedicado

\begin{tabular}{|c|c|c|c|c|}
\hline \multirow{3}{*}{ 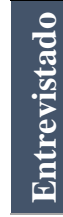 } & \multirow{3}{*}{\begin{tabular}{|l|} 
Unidade de Análise 17 \\
Questão \\
Mensagem principal
\end{tabular}} & \multirow{2}{*}{\multicolumn{3}{|c|}{$\begin{array}{l}\text { Cliente dedicado } \\
\text { Q12: A equipe e as demais áreas acreditavam na implantação do modelo ágil? } \\
\text { Houve aceitação ou resistência das áreas envolvidas? }\end{array}$}} \\
\hline & & & & \\
\hline & & $\begin{array}{l}\text { Interpretação da } \\
\text { mensagem principal }\end{array}$ & Mensagem associada & $\begin{array}{l}\text { Interpretação da } \\
\text { mensagem associada }\end{array}$ \\
\hline E1 & $\begin{array}{l}\text { "A dedicação da área de } \\
\text { negócio e a adaptação do } \\
\text { PO foi um desafio } \\
\text { superado. Antes, eles } \\
\text { não tinham } \\
\text { disponibilidade para } \\
\text { participar, fomos } \\
\text { pedindo } 2 \text { horas por dia, } \\
\text { depois, fomos } \\
\text { aumentando o período e } \\
\text { hoje já está bem } \\
\text { melhor". }\end{array}$ & $\begin{array}{l}\text { Solicitar a participação } \\
\text { do cliente nas principais } \\
\text { cerimônias (por } \\
\text { exemplo: Review e } \\
\text { Planning) e ir } \\
\text { aumentando } \\
\text { paulatinamente a partir } \\
\text { da comprovação dos } \\
\text { benefícios. }\end{array}$ & & \\
\hline E2 & $\begin{array}{l}\text { "Existem algumas áreas } \\
\text { que foram um pouco } \\
\text { resistentes... Elas tinham } \\
\text { que ceder um recurso } \\
\text { delas full time para ficar } \\
\text { em uma estrutura que } \\
\text { deveria cuidar só de } \\
\text { novas demandas... } \\
\text { Então... perder aquele } \\
\text { recurso que antes se } \\
\text { dividia entre projetos e a } \\
\text { condução da operação do } \\
\text { dia a dia foi um } \\
\text { problema". }\end{array}$ & $\begin{array}{l}\text { Dificuldade na alocação } \\
\text { de equipes dedicadas, } \\
\text { pois elas ainda estavam } \\
\text { divididas entre operação } \\
\text { e projetos. }\end{array}$ & & \\
\hline $\mathbf{E 3}$ & $\begin{array}{l}\text { "O timing da 'galera' que } \\
\text { está no dia a dia, na } \\
\text { operação, é totalmente } \\
\text { diferente de quem está } \\
\text { em projeto. Então isso é } \\
\text { difícil, porque eles têm } \\
\text { as prioridades deles, a } \\
\text { gente tem as nossas". }\end{array}$ & $\begin{array}{l}\text { Dificuldade na alocação } \\
\text { de equipes dedicadas, } \\
\text { pois elas ainda estavam } \\
\text { divididas entre operação } \\
\text { e projetos. }\end{array}$ & & \\
\hline E6 & $\begin{array}{l}\text { "Eles tinham as metas } \\
\text { para entregar deles, } \\
\text { então às vezes eles } \\
\text { deixavam de cumprir } \\
\text { algumas coisas. Quando } \\
\text { precisava fazer um } \\
\text { refinement, o PO nunca } \\
\text { estava disponível. O } \\
\text { Product Manager, às } \\
\text { vezes, não atuava como } \\
\text { deveria". }\end{array}$ & $\begin{array}{l}\text { Dificuldade na alocação } \\
\text { de equipes dedicadas, } \\
\text { pois elas ainda estavam } \\
\text { divididas entre operação } \\
\text { e projetos. } \\
\text { Impacto nas metas e na } \\
\text { execução do projeto, } \\
\text { quando o PO não está } \\
\text { disponível em tempo } \\
\text { integral. }\end{array}$ & & \\
\hline MP & $\begin{array}{l}\text { A principal dificuldade } \\
\text { responsabilidades dessas } \\
\text { metas diferenciadas entr }\end{array}$ & & $\begin{array}{l}\text { PO nas equipes ág } \\
\text { ào e projetos. Uma d } \\
\text { m a atuacão das dem }\end{array}$ & $\begin{array}{l}\text { deveu-se ao aumento de } \\
\text { ausas foi a definição de } \\
\text { ireas nos projetos. }\end{array}$ \\
\hline
\end{tabular}

Fonte: Quadro elaborado pela autora, com base nas entrevistas. 
4.2.2.6 Mudança de mindset - coleta de dados primários (UA 19)

A mudança de mindset da organização é um dos pontos mais difíceis da transformação, pois vai além da aplicação das práticas ágeis, requerendo também uma mudança de cultura. A alocação de uma consultoria ou de um coach externo e a criação de uma área de transformação são fatores que podem contribuir para esta mudança na organização.

a) Cultura ágil

Apenas três dos entrevistados (E4, E6 e E7) entenderam que houve efetivamente uma mudança de mindset na organização. No caso do entrevistado E4, esta mentalidade já estava enraizada devido à transformação lean ocorrida anteriormente. Quatro dos entrevistados (E1, E2, E3 e E5) informaram que já tinha ocorrido uma mudança de mindset, porém ainda estava em andamento. Dois dos entrevistados relataram também que existe mentalidade ágil apenas nas áreas de Transformação Digital da organização, que já nasceram com esta cultura. As demais áreas, transformadas do modelo cascata para o ágil, permaneceram com os valores tradicionais (Quadro 31).

Quadro 31 - Análise da coleta de dados: Mudança de mindset - Cultura ágil

\begin{tabular}{|c|c|c|c|c|}
\hline \multirow{4}{*}{ 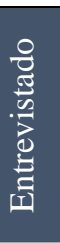 } & Unidade de Análise 19 & \multicolumn{3}{|l|}{ Mudança de mindset } \\
\hline & Questão & \multicolumn{3}{|c|}{ Q23: Houve mudança de mindset ou de cultura da empresa? } \\
\hline & Subunidade & \multicolumn{3}{|l|}{ Cultura ágil } \\
\hline & Mensagem principal & $\begin{array}{c}\text { Interpretação da } \\
\text { mensagem principal }\end{array}$ & Mensagem associada & $\begin{array}{c}\text { Interpretação da } \\
\text { mensagem associada }\end{array}$ \\
\hline E1 & $\begin{array}{l}\text { "Sim, ainda está em } \\
\text { processo". }\end{array}$ & $\begin{array}{l}\text { Houve mudança de } \\
\text { mindset, mas ainda está } \\
\text { em andamento. }\end{array}$ & $\begin{array}{l}\text { "A transformação ágil } \\
\text { está na meta de alguns } \\
\text { executivos de } \\
\text { governança". }\end{array}$ & $\begin{array}{l}\text { É importante que a } \\
\text { transformação digital } \\
\text { esteja na meta } \\
\text { compartilhada da } \\
\text { organização. }\end{array}$ \\
\hline $\mathbf{E 2}$ & $\begin{array}{l}\text { "Eu acho que sim. } \\
\text { Houve essa troca de } \\
\text { mindset, mas eu acho } \\
\text { que tem algumas } \\
\text { pessoas que } \\
\text { desvirtualizaram um } \\
\text { pouco". }\end{array}$ & $\begin{array}{l}\text { Houve mudança de } \\
\text { mindset, mas ainda há } \\
\text { desafios em algumas } \\
\text { áreas. }\end{array}$ & $\begin{array}{l}\text { "Existem áreas } \\
\text { específicas em que isso } \\
\text { está mais enraizado... } \\
\text { onde a gente tem } \\
\text { bastante pessoas que são } \\
\text { mais das antigas... } \\
\text { Existe um pouco mais } \\
\text { de restrição... Mas eu } \\
\text { acho que é um processo } \\
\text { que vai acontecer e se a } \\
\text { pessoa não mudar } \\
\text { rapidamente o mindset, } \\
\text { ela vai ficar por aí". }\end{array}$ & $\begin{array}{l}\text { Existe resistência } \\
\text { principalmente por parte } \\
\text { dos funcionários com } \\
\text { maior tempo de } \\
\text { experiência. Porém, a } \\
\text { transição é uma } \\
\text { realidade e quem não se } \\
\text { adaptar pode ser } \\
\text { substituído. }\end{array}$ \\
\hline
\end{tabular}




\begin{tabular}{|c|c|c|c|c|}
\hline \multirow{4}{*}{ 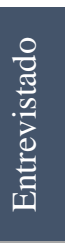 } & Unidade de Análise 19 & \multicolumn{3}{|c|}{ Mudança de mindset (Continuação) } \\
\hline & Questão & \multicolumn{3}{|c|}{ Q23: Houve mudança de mindset ou de cultura da empresa? } \\
\hline & Subunidade & \multicolumn{3}{|l|}{ Cultura ágil } \\
\hline & Mensagem principal & $\begin{array}{c}\text { Interpretação da } \\
\text { mensagem principal }\end{array}$ & Mensagem associada & $\begin{array}{c}\text { Interpretação da } \\
\text { mensagem associada }\end{array}$ \\
\hline $\mathbf{E 3}$ & $\begin{array}{l}\text { "O mindset sim, mas } \\
\text { não que a empresa está } \\
\text { preparada ainda para } \\
\text { isso... falta muito } \\
\text { ainda". }\end{array}$ & $\begin{array}{l}\text { Houve mudança de } \\
\text { mindset, mas ainda está } \\
\text { em andamento. }\end{array}$ & & \\
\hline E4 & $\begin{array}{l}\text { "Na Empresa C é um } \\
\text { pouco difícil de } \\
\text { identificar porque como } \\
\text { ela já tinha passado por } \\
\text { uma transformação lean } \\
\text { antes, então ela já tinha } \\
\text { uma mentalidade bem } \\
\text { enxuta... O que teve de } \\
\text { mudança foi que ela } \\
\text { estava com um foco } \\
\text { muito de redução de } \\
\text { custos por causa do } \\
\text { lean, e eu acho que com } \\
\text { o ágil... eu preciso olhar } \\
\text { também a satisfação do } \\
\text { cliente”. }\end{array}$ & $\begin{array}{l}\text { Houve mudança de } \\
\text { mindset, porém a } \\
\text { empresa já tinha passado } \\
\text { por uma transformação } \\
\text { lean anteriormente. }\end{array}$ & & \\
\hline E5 & $\begin{array}{l}\text { "Acho que já havia um } \\
\text { movimento pela própria } \\
\text { transformação cultural } \\
\text { da Empresa A, mas sim, } \\
\text { eu acho que põe o dedo } \\
\text { na ferida, expõe os } \\
\text { problemas e faz você } \\
\text { tomar uma atitude". }\end{array}$ & $\begin{array}{l}\text { Houve mudança de } \\
\text { mindset, mas ainda está } \\
\text { em andamento. }\end{array}$ & & \\
\hline E6 & "Sim, sem volta". & $\begin{array}{l}\text { Houve mudança de } \\
\text { mindset e é um caminho } \\
\text { sem volta. }\end{array}$ & & \\
\hline E7 & $\begin{array}{l}\text { "O time acompanhou } \\
\text { bem... O pessoal de TI } \\
\text { que migrou, todo mundo } \\
\text { gostou". }\end{array}$ & $\begin{array}{l}\text { Houve mudança de } \\
\text { mindset na organização } \\
\text { e foi bem recebida pela } \\
\text { equipe de Tecnologia. }\end{array}$ & $\begin{array}{l}\text { "Quem se adaptou, } \\
\text { acompanhou bem. } \\
\text { Quem não se adaptou, } \\
\text { saiu". }\end{array}$ & $\begin{array}{l}\text { Houve desligamento de } \\
\text { funcionários que não se } \\
\text { adaptaram ao novo } \\
\text { processo. }\end{array}$ \\
\hline E8 & $\begin{array}{l}\text { "Eu acho que o ágil se } \\
\text { adaptou à empresa, né, } \\
\text { ao contrário. Não é a } \\
\text { empresa que se adaptou } \\
\text { ao ágil". }\end{array}$ & $\begin{array}{l}\text { Não houve mudança de } \\
\text { cultura. Foram } \\
\text { implementadas apenas } \\
\text { as práticas ágeis que } \\
\text { faziam sentido para a } \\
\text { organização. }\end{array}$ & & \\
\hline
\end{tabular}

(Continua) 


\begin{tabular}{|c|c|c|c|c|}
\hline & Unidade de Análise 19 & \multicolumn{3}{|c|}{ Mudança de mindset (Continuação) } \\
\hline 0 & Questão & \multicolumn{3}{|c|}{ Q23: Houve mudança de mindset ou de cultura da empresa? } \\
\hline 忩 & Subunidade & \multicolumn{3}{|l|}{ Cultura ágil } \\
\hline 迳 & Mensagem principal & $\begin{array}{c}\text { Interpretação da } \\
\text { mensagem principal }\end{array}$ & Mensagem associada & $\begin{array}{c}\text { Interpretação da } \\
\text { mensagem associada }\end{array}$ \\
\hline E9 & $\begin{array}{l}\text { "De jeito nenhum. Só no } \\
\text { Digital. Está muito } \\
\text { longe de ter um mindset } \\
\text { ágil, muito longe". }\end{array}$ & $\begin{array}{l}\text { Houve mudança de } \\
\text { mindset apenas na área } \\
\text { Digital. O restante da } \\
\text { organização ainda } \\
\text { possui a mentalidade } \\
\text { tradicional. }\end{array}$ & $\begin{array}{l}\text { "O principal medo dele } \\
\text { era que a gente criasse } \\
\text { uma cultura de um } \\
\text { banco apartado... e que } \\
\text { isso gerasse ciumeira, } \\
\text { pouco envolvimento dos } \\
\text { diretores... Espalhou o } \\
\text { Digital nas áreas, em } \\
\text { várias diretorias... Eu } \\
\text { tenho a dificuldade } \\
\text { agora da governança... } \\
\text { Existe uma chance de } \\
\text { você criar uma cultura } \\
\text { digital em cada } \\
\text { diretoria". }\end{array}$ & $\begin{array}{l}\text { A área Digital foi } \\
\text { dissolvida internamente } \\
\text { na organização para } \\
\text { evitar a criação de uma } \\
\text { cultura diferenciada. } \\
\text { Porém, este novo } \\
\text { modelo possui o risco de } \\
\text { criação de uma cultura } \\
\text { Digital em cada } \\
\text { diretoria. }\end{array}$ \\
\hline E10 & $\begin{array}{l}\text { "Cada área tem o seu } \\
\text { próprio vício. Não tem } \\
\text { um mindset corporativo } \\
\text { com relação a isso... } \\
\text { Eles se organizam com } \\
\text { PM, PO, BO. Então, } \\
\text { assim, o mindset da } \\
\text { companhia já entende } \\
\text { essas siglas. Só não } \\
\text { funcionam como } \\
\text { deveriam funcionar, na } \\
\text { maioria dos casos". }\end{array}$ & $\begin{array}{l}\text { Não existe um mindset } \\
\text { único da organização. } \\
\text { Cada área possui uma } \\
\text { cultura diferente. }\end{array}$ & $\begin{array}{l}\text { "Como é o mindset } \\
\text { deles? Eu sou diretor, } \\
\text { então eu falo com } \\
\text { quem? Eu só posso falar } \\
\text { com diretor". }\end{array}$ & $\begin{array}{l}\text { Ainda existe o mindset } \\
\text { de hierarquia do modelo } \\
\text { tradicional. }\end{array}$ \\
\hline MP & \multicolumn{4}{|c|}{$\begin{array}{l}\text { A mudança de mindset na organização refere-se principalmente à aceitação do novo modelo de tomada } \\
\text { de decisão descentralizada pelas equipes e pelos executivos das organizações mais hierárquicas, e } \\
\text { também à aplicação dos novos processos de priorização e de experimentação, bastante disruptivos em } \\
\text { relação ao modelo tradicional. Em alguns casos, a mudança de mindset ocorreu apenas em algumas áreas } \\
\text { da organização, resultando em culturas diferenciadas entre as áreas. }\end{array}$} \\
\hline
\end{tabular}

Fonte: Quadro elaborado pela autora, com base nas entrevistas.

b) Contratação de consultoria

Uma das formas mais eficazes de pregar a mudança de mindset na organização é por meio da contratação de uma consultoria ou de uma equipe de transição para apoiar a transformação. No caso de uma consultoria externa, além de trazer a expertise do mercado, também aloca uma equipe isenta à organização, sem os vícios dos processos atuais, gerando menor resistência com as áreas internas. O papel dessa equipe na transição é importantíssimo, desde a aplicação das práticas e valores ágeis até o acompanhamento dos times e a divulgação dos resultados. 
Todos os entrevistados informaram que houve a contratação de uma consultoria externa para implementar a transição, variando apenas em relação ao escopo de atuação e ao momento da contratação. Nove dentre os dez entrevistados acreditaram que a consultoria foi imprescindível para a definição da estratégia e para a execução da transição. Apenas um entrevistado (E3) teve a percepção de que a consultoria não agregou valor à transição (Quadro 32).

Quadro 32 - Análise da coleta de dados: Mudança de mindset - Contratação de consultoria

\begin{tabular}{|c|c|c|c|c|}
\hline \multirow{4}{*}{ 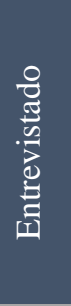 } & Unidade de Análise 19 & \multicolumn{3}{|l|}{ Mudança de mindset } \\
\hline & Questão & \multicolumn{3}{|c|}{$\begin{array}{l}\text { Q4: Houve a alocação de uma equipe de transformação ou de um coach para } \\
\text { auxiliar na transição? } \\
\text { Você acha que foi importante para a transformação? }\end{array}$} \\
\hline & Subunidade & \multicolumn{3}{|l|}{ Contratação de consultoria } \\
\hline & Mensagem principal & $\begin{array}{l}\text { Interpretação da } \\
\text { mensagem principal }\end{array}$ & Mensagem associada & $\begin{array}{l}\text { Interpretação da } \\
\text { mensagem associada }\end{array}$ \\
\hline E1 & $\begin{array}{l}\text { "Teve a contratação de } \\
\text { uma consultoria externa } \\
\text { para apoiar na } \\
\text { transformação... Foi } \\
\text { definida uma equipe } \\
\text { interna de transformação } \\
\text { que incluía... uma } \\
\text { equipe multidisciplinar } \\
\text { que lidera o projeto de } \\
\text { Transformação Âgil na } \\
\text { companhia... A } \\
\text { consultoria dava o } \\
\text { treinamento e treinava } \\
\text { facilitadores". }\end{array}$ & $\begin{array}{l}\text { Houve a contratação de } \\
\text { uma consultoria externa } \\
\text { especializada em } \\
\text { Transformação Digital, } \\
\text { que realizava os } \\
\text { treinamentos. Também } \\
\text { foi criada uma equipe de } \\
\text { transformação interna na } \\
\text { organização. }\end{array}$ & $\begin{array}{l}\text { "A consultoria foi } \\
\text { fundamental para a } \\
\text { disseminação da cultura } \\
\text { ágil, para aplicar } \\
\text { treinamentos, as } \\
\text { ferramentas e } \\
\text { cerimônias. A equipe } \\
\text { interna é alinhada com a } \\
\text { consultoria e eles são } \\
\text { responsáveis por fazer o } \\
\text { contato com as outras } \\
\text { equipes da empresa". }\end{array}$ & $\begin{array}{l}\text { O papel da consultoria } \\
\text { foi fundamental para a } \\
\text { disseminação do } \\
\text { mindset ágil. }\end{array}$ \\
\hline $\mathbf{E 2}$ & $\begin{array}{l}\text { "A consultoria fez todo } \\
\text { o processo de transição } \\
\text { da Empresa B para a } \\
\text { Transformação Digital". }\end{array}$ & $\begin{array}{l}\text { Houve a contratação de } \\
\text { uma consultoria externa } \\
\text { especializada em } \\
\text { Transformação Digital. }\end{array}$ & $\begin{array}{l}\text { "Super importante, } \\
\text { porque ela é uma } \\
\text { empresa que já } \\
\text { participou de } \\
\text { transformações digitais } \\
\text { em outras empresas. } \\
\text { Então, ela já sabe os } \\
\text { gargalos, os ofensores e } \\
\text { conseguiu nos ajudar a } \\
\text { passar por eles de uma } \\
\text { forma um pouco mais } \\
\text { branda". }\end{array}$ & $\begin{array}{l}\text { O papel da consultoria } \\
\text { foi fundamental, pois ela } \\
\text { já tem a expertise de } \\
\text { mercado e consegue } \\
\text { atuar nos principais } \\
\text { desafios. }\end{array}$ \\
\hline $\mathbf{E 3}$ & $\begin{array}{l}\text { "Teve consultoria mais } \\
\text { para impor como seriam } \\
\text { as entregas, a } \\
\text { metodologia que a gente } \\
\text { iria trabalhar". }\end{array}$ & $\begin{array}{l}\text { Houve a contratação de } \\
\text { uma consultoria externa } \\
\text { para aplicação do novo } \\
\text { modelo de trabalho. }\end{array}$ & $\begin{array}{l}\text { "Eu não acho que } \\
\text { agregou muito não. } \\
\text { Tanto que a gente } \\
\text { levava os inputs, eles } \\
\text { ajustavam. Mas não } \\
\text { acho que foi uma coisa } \\
\text { imprescindível". }\end{array}$ & $\begin{array}{l}\text { O papel da consultoria } \\
\text { não foi imprescindível } \\
\text { para a transformação. }\end{array}$ \\
\hline
\end{tabular}

(Continua) 


\begin{tabular}{|c|c|c|c|c|}
\hline \multirow{4}{*}{ 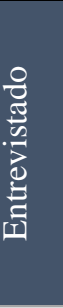 } & Unidade de Análise 19 & \multicolumn{3}{|c|}{ Mudança de mindset (Continuação) } \\
\hline & Questão & \multicolumn{3}{|c|}{$\begin{array}{l}\text { Q4: Houve a alocação de uma equipe de transformação ou de um coach para } \\
\text { auxiliar na transição? } \\
\text { Você acha que foi importante para a transformação? }\end{array}$} \\
\hline & Subunidade & \multicolumn{3}{|l|}{ Contratação de consultoria } \\
\hline & Mensagem principal & $\begin{array}{c}\text { Interpretação da } \\
\text { mensagem principal }\end{array}$ & Mensagem associada & $\begin{array}{c}\text { Interpretação da } \\
\text { mensagem associada }\end{array}$ \\
\hline $\mathbf{E 4}$ & $\begin{array}{l}\text { "Era um coach que foi } \\
\text { contratado externo para } \\
\text { começar na Costa Rica. } \\
\text { Era o piloto, e depois } \\
\text { fazer a replicação para } \\
\text { os outros países". }\end{array}$ & $\begin{array}{l}\text { Houve a contratação de } \\
\text { um coach externo, em } \\
\text { uma segunda fase, para } \\
\text { iniciar a transição em } \\
\text { um país e escalar para } \\
\text { os demais países da } \\
\text { organização. }\end{array}$ & $\begin{array}{l}\text { "Eu tive um gestor que } \\
\text { me deixou fazer o que } \\
\text { eu queria... A gente } \\
\text { tomava essas decisões } \\
\text { com o time". }\end{array}$ & $\begin{array}{l}\text { Inicialmente, a transição } \\
\text { ocorreu apenas na } \\
\text { equipe pela proatividade } \\
\text { da gestora. }\end{array}$ \\
\hline E5 & $\begin{array}{l}\text { "Com a consultoria, a } \\
\text { gente começou a fazer } \\
\text { os pilotos de verdade... } \\
\text { A gente deu sequência e } \\
\text { criou o LACE (Lean } \\
\text { Agile Center of } \\
\text { Excellence), que é o } \\
\text { grupo de } \\
\text { transformação". }\end{array}$ & $\begin{array}{l}\text { Houve a contratação de } \\
\text { uma consultoria externa } \\
\text { especializada, para } \\
\text { impulsionar a transição. } \\
\text { Também foi criada uma } \\
\text { equipe de transformação } \\
\text { interna na organização. }\end{array}$ & $\begin{array}{l}\text { "A gente ensina quais } \\
\text { são os papéis, quais são } \\
\text { as cerimonias... a gente } \\
\text { dá treinamento, dá } \\
\text { suporte para } S c r u m \\
\text { Master e para o } P O \text { ". }\end{array}$ & $\begin{array}{l}\text { O escopo do projeto foi } \\
\text { a realização de } \\
\text { treinamentos e } \\
\text { acompanhamento com } \\
\text { as equipes. }\end{array}$ \\
\hline E6 & $\begin{array}{l}\text { "Eu contratei uma } \\
\text { consultoria... Além de } \\
\text { toda a parte técnica, eu } \\
\text { tinha um profissional } \\
\text { que olhava a parte } \\
\text { humana, comunicação } \\
\text { visual". }\end{array}$ & $\begin{array}{l}\text { Houve a contratação de } \\
\text { uma consultoria externa } \\
\text { para definição do novo } \\
\text { modelo de trabalho, } \\
\text { incluindo Change } \\
\text { Management e } \\
\text { comunicação. }\end{array}$ & $\begin{array}{l}\text { "Agregou muito... } \\
\text { trouxe um } \\
\text { conhecimento que por } \\
\text { mais que eu tivesse } \\
\text { ali... eles trazem uma } \\
\text { visão de transformação. } \\
\text { Então, eles agregaram } \\
\text { muito com essa } \\
\text { expertise no time". }\end{array}$ & $\begin{array}{l}\text { O papel da consultoria } \\
\text { foi fundamental, pois ela } \\
\text { já tem a expertise do } \\
\text { mercado. }\end{array}$ \\
\hline E7 & $\begin{array}{l}\text { "Eles contrataram uma } \\
\text { empresa especialista em } \\
\text { agilidade... O Agile } \\
\text { Coach faz isso, dá } \\
\text { treinamento, acompanha } \\
\text { o time... até o time } \\
\text { atingir a maturidade. } \\
\text { Porque senão, o pessoal } \\
\text { abandona". }\end{array}$ & $\begin{array}{l}\text { Houve a contratação de } \\
\text { uma consultoria externa } \\
\text { para a realização de } \\
\text { treinamentos e } \\
\text { acompanhamento das } \\
\text { equipes. }\end{array}$ & $\begin{array}{l}\text { "Ele fez proposta para o } \\
\text { pessoal da Consultoria } \\
\text { virar interno da } \\
\text { Empresa E, e vários } \\
\text { Agile Coaches } \\
\text { aceitaram, aí e tirou a } \\
\text { Consultoria de lá... E } \\
\text { teve até um problema } \\
\text { com a Consultoria... } \\
\text { Ficou um clima bem } \\
\text { ruim". }\end{array}$ & $\begin{array}{l}\text { Houve contratação em } \\
\text { massa dos funcionários } \\
\text { da consultoria pela } \\
\text { organização, o que } \\
\text { gerou conflito. }\end{array}$ \\
\hline $\mathbf{E 8}$ & $\begin{array}{l}\text { "A gente tem o } \\
\text { privilégio de ter um } \\
\text { Agile Coach muito } \\
\text { especial, ele dá muitas } \\
\text { orientações... é uma } \\
\text { consultoria externa". }\end{array}$ & $\begin{array}{l}\text { Houve a contratação de } \\
\text { um coach externo para } \\
\text { orientar a equipe. }\end{array}$ & $\begin{array}{l}\text { "Ele vai on demand } \\
\text { para a gente. Então, ele } \\
\text { vai umas duas vezes por } \\
\text { semana. Ele faz alguns } \\
\text { eventos com a gente. } \\
\text { Ele facilita algumas } \\
\text { reuniões... A gente pede } \\
\text { orientação". }\end{array}$ & $\begin{array}{l}\text { A contratação foi } \\
\text { realizada on demand, } \\
\text { sem a definição de um } \\
\text { modelo de trabalho fixo. }\end{array}$ \\
\hline
\end{tabular}

(Continua) 


\begin{tabular}{|c|c|c|c|c|}
\hline \multirow{4}{*}{ 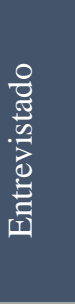 } & Unidade de Análise 19 & \multicolumn{3}{|c|}{ Mudança de mindset (Continuação) } \\
\hline & Questão & \multicolumn{3}{|c|}{$\begin{array}{l}\text { Q4: Houve a alocação de uma equipe de transformação ou de um coach para } \\
\text { auxiliar na transição? } \\
\text { Você acha que foi importante para a transformação? }\end{array}$} \\
\hline & Subunidade & \multicolumn{3}{|l|}{ Contratação de consultoria } \\
\hline & Mensagem principal & $\begin{array}{c}\text { Interpretação da } \\
\text { mensagem principal }\end{array}$ & Mensagem associada & $\begin{array}{c}\text { Interpretação da } \\
\text { mensagem associada }\end{array}$ \\
\hline E9 & $\begin{array}{l}\text { "A gente, inicialmente, } \\
\text { teve a consultoria } \\
\text { ajudando... Foi } \\
\text { promover o início da } \\
\text { digitalização... Veio } \\
\text { para fazer a estratégia do } \\
\text { modelo operacional, } \\
\text { mas eles também } \\
\text { implementaram... Foi } \\
\text { fundamental essa ajuda". }\end{array}$ & $\begin{array}{l}\text { Houve a contratação de } \\
\text { uma consultoria externa } \\
\text { para definição da } \\
\text { estratégia e da } \\
\text { implementação da } \\
\text { transformação. }\end{array}$ & $\begin{array}{l}\text { "Vem o bonitão, super } \\
\text { inteligente, que cobra } \\
\text { uma fortuna e te fala } \\
\text { uma estratégia linda, } \\
\text { maravilhosa. Na hora de } \\
\text { implementar... o } \\
\text { negócio não funciona... } \\
\text { A gente falou, o que } \\
\text { você falar você vai } \\
\text { implementar. Quando } \\
\text { você coloca uma } \\
\text { consultoria, eles estão } \\
\text { falando a mesma coisa } \\
\text { que a gente está } \\
\text { falando, a diferença é } \\
\text { que a gente está } \\
\text { pagando muitos milhões } \\
\text { por isso e todo mundo } \\
\text { acredita". }\end{array}$ & $\begin{array}{l}\text { A entrevistada ressaltou } \\
\text { a importância da } \\
\text { implementação pela } \\
\text { própria consultoria, } \\
\text { além da quebra de } \\
\text { resistência interna por se } \\
\text { tratar de uma } \\
\text { consultoria externa. }\end{array}$ \\
\hline E10 & $\begin{array}{l}\text { "E o PMO está virando } \\
\text { um TMO - } \\
\text { Transformation } \\
\text { Management Office... E } \\
\text { chamaram... alguns } \\
\text { consultores... para } \\
\text { impulsionar essa } \\
\text { transformação. E eu } \\
\text { estou entre eles... para } \\
\text { gerar um produto novo } \\
\text { da empresa". }\end{array}$ & $\begin{array}{l}\text { Houve a contratação de } \\
\text { alguns consultores para } \\
\text { impulsionar a } \\
\text { transformação, em } \\
\text { paralelo com a gestão } \\
\text { dos projetos de } \\
\text { implementação de novos } \\
\text { produtos. }\end{array}$ & $\begin{array}{l}\text { "Eu sou Agile Master, } \\
\text { mas funciono também } \\
\text { como Agile Coach em } \\
\text { alguns momentos, como } \\
\text { Scrum Master em } \\
\text { outros momentos". }\end{array}$ & $\begin{array}{l}\text { O consultor possui um } \\
\text { papel triplo de Agile } \\
\text { Master, Agile Coach e } \\
\text { Scrum Master. }\end{array}$ \\
\hline MP & \multicolumn{4}{|c|}{$\begin{array}{l}\text { O escopo de atuação das consultorias variou entre as organizações, incluindo a realização de } \\
\text { treinamentos, a aplicação de assessments para medir o nível de maturidade e o aculturamento das } \\
\text { equipes em fase de transição. A alocação de um Agile Coach para realizar o acompanhamento das } \\
\text { equipes foi um fator primordial para gerar engajamento, fortalecer o conhecimento e evitar o abandono } \\
\text { das práticas. Outro benefício mencionado por um dos entrevistados foi a contratação da consultoria para } \\
\text { realizar tanto a estratégia quanto a operacionalização da transição, podendo ajustar o modelo proposto } \\
\text { de acordo com os resultados obtidos. }\end{array}$} \\
\hline
\end{tabular}

Fonte: Quadro elaborado pela autora, com base nas entrevistas.

\subsubsection{Desafios da Gestão na Análise da Coleta de Dados Primários}

\subsubsection{Gestão descentralizada - coleta de dados primários (UA 21)}

A gestão pode apresentar certa resistência durante o processo de transição, por não aceitar a descentralização da tomada de decisão, que reduz o poder dos executivos. Sendo 
assim, a literatura recomenda que a equipe de transição auxilie na redefinição do papel da gestão e do tipo de controle que irá exercer, de forma a minimizar esta resistência.

Nas entrevistas realizadas, seis dos entrevistados (E1, E2, E4, E5, E9 e E10) informaram que houve resistência por parte dos executivos, principalmente no nível da média gestão (gerentes e coordenadores). Os principais motivos foram a perda do poder, a disponibilização de recursos das áreas para os projetos e a visibilidade das atividades da equipe advindas do modelo ágil. Outra dificuldade mencionada pelos entrevistados E2 e E4 foi o conhecimento do negócio que as equipes passam a ter com o modelo ágil, possibilitando o questionamento em relação ao valor que cada melhoria gera para o cliente. Um dos entrevistados (E10) mencionou que a resistência ocorreu pelo fato de a gestão da organização não acreditar no modelo ágil.

Dentre os entrevistados que declararam não ter havido resistência, um deles (E6) relatou que a transição para o modelo ágil foi apoiada pelo presidente da organização, o que reduziu a resistência da alta gestão. Mesmo assim, em alguns casos, houve dificuldade na aceitação das mudanças propostas pelo novo modelo. Outro entrevistado (E8) afirmou que acreditava não ter havido resistência da gestão, porém, ao mesmo tempo, explicou que o corpo executivo não possuía o entendimento completo quanto ao modelo ágil (Quadro 33).

Quadro 33 - Análise da coleta de dados: Gestão descentralizada

\begin{tabular}{|c|c|c|c|c|}
\hline \multirow{3}{*}{ 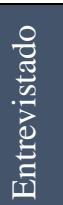 } & Unidade de Análise 21 & \multicolumn{3}{|l|}{ Gestão descentralizada } \\
\hline & Questão & \multicolumn{3}{|c|}{ Q9: Houve resistência da gestão na implantação ágil? } \\
\hline & Mensagem principal & $\begin{array}{l}\text { Interpretação da } \\
\text { mensagem principal }\end{array}$ & Mensagem associada & $\begin{array}{l}\text { Interpretação da } \\
\text { mensagem associada }\end{array}$ \\
\hline E1 & $\begin{array}{l}\text { "Teve resistência } \\
\text { principalmente da } \\
\text { gestão, pela questão da } \\
\text { hierarquia... Alguns } \\
\text { gestores têm medo de } \\
\text { perder o poder com a } \\
\text { descentralização das } \\
\text { decisões". }\end{array}$ & $\begin{array}{l}\text { Dificuldade na } \\
\text { descentralização das } \\
\text { decisões e medo de } \\
\text { perda do poder por parte } \\
\text { da média gestão. }\end{array}$ & & \\
\hline E2 & $\begin{array}{l}\text { "Você está mexendo } \\
\text { num território que é } \\
\text { meu, do que você está } \\
\text { falando? Sou eu quem } \\
\text { mando aqui". }\end{array}$ & $\begin{array}{l}\text { Medo de perda do poder } \\
\text { por parte da média } \\
\text { gestão. }\end{array}$ & $\begin{array}{l}\text { "Existem algumas áreas } \\
\text { que foram um pouco } \\
\text { resistentes... Elas } \\
\text { tinham que ceder um } \\
\text { recurso delas full time. } \\
\text { Ficar numa estrutura } \\
\text { que deveria cuidar só } \\
\text { de novas demandas". }\end{array}$ & $\begin{array}{l}\text { Dificuldade em ceder } \\
\text { recursos para as equipes } \\
\text { ágeis e medo de perder } \\
\text { a equipe. }\end{array}$ \\
\hline
\end{tabular}




\begin{tabular}{|c|c|c|c|c|}
\hline \multirow{3}{*}{ 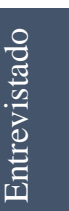 } & \multirow{2}{*}{\begin{tabular}{|l|} 
Unidade de Análise 21 \\
Questão
\end{tabular}} & \multicolumn{3}{|c|}{ Gestão descentralizada (Continuação) } \\
\hline & & \multicolumn{3}{|c|}{ Q9: Houve resistência da gestão na implantação ágil? } \\
\hline & Mensagem principal & $\begin{array}{l}\text { Interpretação da } \\
\text { mensagem principal }\end{array}$ & Mensagem associada & $\begin{array}{l}\text { Interpretação da } \\
\text { mensagem associada }\end{array}$ \\
\hline $\mathbf{E 3}$ & $\begin{array}{l}\text { "Não, eu acho que o } \\
\text { movimento da liderança } \\
\text { foi OK para a } \\
\text { transformação... Pelo } \\
\text { menos isso na liderança } \\
\text { eu não vejo, eles querem } \\
\text { sim ser mais ágeis". }\end{array}$ & $\begin{array}{l}\text { A percepção da } \\
\text { entrevistada foi de que } \\
\text { não há resistência da } \\
\text { liderança da } \\
\text { organização. }\end{array}$ & & \\
\hline E4 & $\begin{array}{l}\text { "A média gestão é o } \\
\text { maior desafio... Por que } \\
\text { você está vindo aqui } \\
\text { mexer com o meu time, } \\
\text { com a forma como eu } \\
\text { trabalho? Depois disso, } \\
\text { aqui o time vai ser auto } \\
\text { organizável, qual vai ser } \\
\text { o meu papel? Então, não } \\
\text { vai mais precisar de } \\
\text { gestão?" }\end{array}$ & $\begin{array}{l}\text { Medo de perda do poder } \\
\text { por parte da média } \\
\text { gestão. }\end{array}$ & & \\
\hline E5 & $\begin{array}{l}\text { "Sempre tem resistência. } \\
\text { O que eu vou fazer } \\
\text { agora? O que sobra para } \\
\text { mim? Perdi a equipe... } \\
\text { média gestão é o que } \\
\text { gera mais resistência". }\end{array}$ & $\begin{array}{l}\text { Medo de perda tanto do } \\
\text { poder quanto da equipe } \\
\text { por parte da média } \\
\text { gestão. }\end{array}$ & & \\
\hline E6 & $\begin{array}{l}\text { "Quando o presidente } \\
\text { bate o martelo a coisa } \\
\text { flui. Resistência não, } \\
\text { mas, em alguns } \\
\text { momentos, poderia ter } \\
\text { mais apoio". }\end{array}$ & $\begin{array}{l}\text { Houve baixa resistência } \\
\text { da gestão, devido ao } \\
\text { apoio do presidente. }\end{array}$ & & \\
\hline E8 & $\begin{array}{l}\text { "Não, porque o Delivery } \\
\text { Manager que trouxe... } \\
\text { Acho que não teve } \\
\text { empecilho não. Eu acho } \\
\text { que eles gostam, mas eu } \\
\text { acho que em algumas } \\
\text { coisas culturais as } \\
\text { pessoas ainda não têm o } \\
\text { mindset". }\end{array}$ & $\begin{array}{l}\text { Apesar de a entrevistada } \\
\text { mencionar que não } \\
\text { houve resistência por } \\
\text { parte da gestão, ela } \\
\text { também relatou que não } \\
\text { houve absorção total da } \\
\text { cultura ágil pelos } \\
\text { executivos. }\end{array}$ & $\begin{array}{l}\text { "O executivo nem } \\
\text { sempre esteve inserido. } \\
\text { Ele pode ter visto, eu } \\
\text { sei o que é ágil, tem as } \\
\text { cerimônias, roda a } \\
\text { sprint, mas ele, talvez, } \\
\text { não saiba o que é } \\
\text { mesmo". }\end{array}$ & $\begin{array}{l}\text { Os executivos não } \\
\text { possuem o } \\
\text { entendimento quanto ao } \\
\text { que é o modelo ágil, } \\
\text { dificultando a sua } \\
\text { aplicação e reforçando a } \\
\text { necessidade de } \\
\text { participação de todos os } \\
\text { níveis nos treinamentos. }\end{array}$ \\
\hline E9 & $\begin{array}{l}\text { "Você migrar de um } \\
\text { banco tradicional, } \\
\text { comando e controle, } \\
\text { para um banco ágil, com } \\
\text { autonomia e } \\
\text { independência, é muito } \\
\text { difícil". }\end{array}$ & $\begin{array}{l}\text { Dificuldade de mudança } \\
\text { de cultura na } \\
\text { organização, } \\
\text { principalmente em } \\
\text { organizações } \\
\text { tradicionalmente } \\
\text { hierárquicas, no modelo } \\
\text { de comando e controle. }\end{array}$ & $\begin{array}{l}\text { "A gente conseguiu } \\
\text { isso dentro do Digital, } \\
\text { mas a gente não } \\
\text { conseguiu isso para o } \\
\text { resto do banco". }\end{array}$ & $\begin{array}{l}\text { Criação de culturas } \\
\text { diferenciadas no interior } \\
\text { da organização. }\end{array}$ \\
\hline E10 & $\begin{array}{l}\text { "O Escritório de Projetos } \\
\text { pediu para que eu } \\
\text { implementasse o modelo } \\
\text { ágil. Só que as } \\
\text { lideranças não acreditam } \\
\text { nesse modelo". }\end{array}$ & $\begin{array}{l}\text { Dificuldade na transição, } \\
\text { quando a liderança não } \\
\text { acredita no novo } \\
\text { modelo. }\end{array}$ & & (Continua) \\
\hline
\end{tabular}




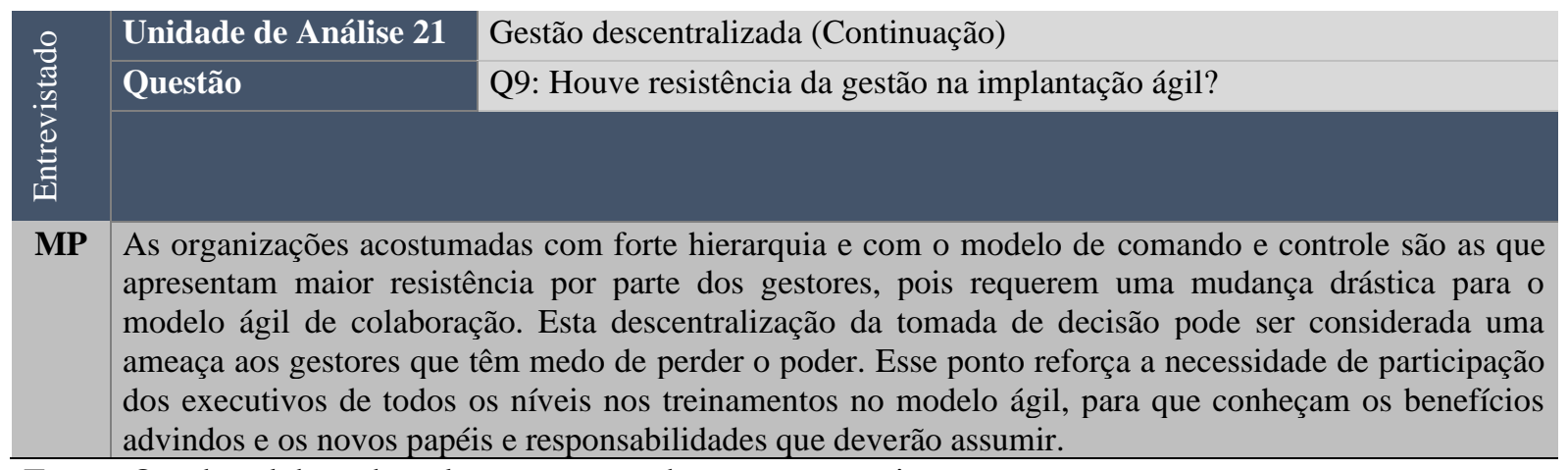

Fonte: Quadro elaborado pela autora, com base nas entrevistas.

\subsubsection{Desafios da Organização na Análise da Coleta de Dados Primários}

4.2.4.1 Estrutura hierárquica - coleta de dados primários (UA 22)

O modelo ágil prevê a horizontalização da estrutura hierárquica, além da formação de equipes multidisciplinares e não mais funcionais.

a) Redução dos níveis hierárquicos

Apenas o entrevistado E7 mencionou que houve redução dos níveis hierárquicos da organização depois da transição ágil, com a eliminação do nível de Coordenador na área de Tecnologia e com a distribuição de suas atividades aos demais membros da equipe. Outro entrevistado (E9) relatou que a horizontalização ocorreu a partir da dissolução da área de Transformação Digital por toda a organização, com o objetivo de disseminar a estratégia digital para todas as demais áreas. Porém, houve apenas redução no nível de tomada de decisão e não na estrutura hierárquica. Os demais entrevistados informaram que não houve redução de níveis hierárquicos, principalmente em organizações com uma hierarquia forte. Em um dos casos (E6), este achatamento de estrutura ocorreu antes mesmo da transformação ágil (Quadro 34). 
Quadro 34 - Análise da coleta de dados: Estrutura hierárquica - Redução dos níveis hierárquicos

\begin{tabular}{|c|c|c|c|c|}
\hline \multirow{4}{*}{ 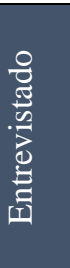 } & Unidade de Análise 22 & \multicolumn{3}{|l|}{ Estrutura hierárquica } \\
\hline & Questão & \multicolumn{3}{|c|}{$\begin{array}{l}\text { Q15: Quais os impactos na estrutura de cargos da empresa e níveis } \\
\text { hierárquicos? }\end{array}$} \\
\hline & Subunidade & \multicolumn{3}{|c|}{ Redução dos níveis hierárquicos } \\
\hline & Mensagem principal & $\begin{array}{l}\text { Interpretação da } \\
\text { mensagem principal }\end{array}$ & Mensagem associada & $\begin{array}{l}\text { Interpretação da } \\
\text { mensagem associada }\end{array}$ \\
\hline E2 & $\begin{array}{l}\text { "Não. E esse é um ponto } \\
\text { que desde o começo do } \\
\text { processo de } \\
\text { transformação está no } \\
\text { pipeline do time de } \\
\text { Change Management". }\end{array}$ & $\begin{array}{l}\text { Não houve } \\
\text { horizontalização da } \\
\text { estrutura da organização. }\end{array}$ & & \\
\hline $\mathbf{E 3}$ & $\begin{array}{l}\text { "Não passou a ser mais } \\
\text { horizontal". }\end{array}$ & $\begin{array}{l}\text { Não houve } \\
\text { horizontalização da } \\
\text { estrutura da organização. }\end{array}$ & & \\
\hline E6 & $\begin{array}{l}\text { "Achatamento de } \\
\text { estrutura não, porque já } \\
\text { tinha, inclusive, sido } \\
\text { feito um trabalho alguns } \\
\text { anos antes que já tinha } \\
\text { eliminado alguns cargos } \\
\text { intermediários... Não } \\
\text { tinha mais } \\
\text { superintendente". }\end{array}$ & $\begin{array}{l}\text { Não houve } \\
\text { horizontalização da } \\
\text { estrutura da organização, } \\
\text { pois o nível de } \\
\text { superintendente já havia } \\
\text { sido eliminado } \\
\text { anteriormente. }\end{array}$ & & \\
\hline E7 & $\begin{array}{l}\text { "Eu tenho a impressão } \\
\text { que sim. Porque antes } \\
\text { tinham poucos } \\
\text { coordenadores e esses } \\
\text { coordenadores eram } \\
\text { muito centralizadores... } \\
\text { Agora não... ficou mais } \\
\text { diluído entre muitos". }\end{array}$ & $\begin{array}{l}\text { Houve a redução do } \\
\text { nível de coordenador e } \\
\text { distribuição de trabalho } \\
\text { entre os diversos Team } \\
\text { Leads. }\end{array}$ & $\begin{array}{l}\text { "Foi tudo para o olho } \\
\text { da rua". }\end{array}$ & $\begin{array}{l}\text { A redução do nível do } \\
\text { coordenador ocorreu } \\
\text { por meio de demissão } \\
\text { dos funcionários. }\end{array}$ \\
\hline E9 & $\begin{array}{l}\text { "A estrutura de cargos } \\
\text { continua hierarquizada. } \\
\text { A estrutura de tomada de } \\
\text { decisão está } \\
\text { horizontalizada" }\end{array}$ & $\begin{array}{l}\text { A entrevistada informou } \\
\text { que houve } \\
\text { horizontalização, porém, } \\
\text { apenas, na tomada de } \\
\text { decisão e não na } \\
\text { estrutura hierárquica. }\end{array}$ & & \\
\hline MP & $\begin{array}{l}\text { A transformação ágil não } \\
\text { os níveis hierárquicos vig } \\
\text { tomada de decisão. }\end{array}$ & $\begin{array}{l}\text { está alterando a estrutura } \\
\text { entes, o que pode contribu }\end{array}$ & $\begin{array}{l}\text { S organizações, mant } \\
\text { para a resistência da } g\end{array}$ & $\begin{array}{l}\text { do, na maioria das vezes, } \\
\text { são à descentralização na }\end{array}$ \\
\hline
\end{tabular}

Fonte: Quadro elaborado pela autora, com base nas entrevistas.

b) Alteração na estrutura de cargos

Quanto à alteração na estrutura de cargos, a maioria dos entrevistados (E3, E4, E6, E7, E8, E9 e E10) relatou que houve uma renomeação e criação de novos cargos na organização, por exemplo: Analistas de Marketing passaram a ser Product Owners ou Gerentes de Projetos tornaram-se Scrum Masters ou Agile Experts. Dois dos entrevistados (E1 e E5) informaram 
que não houve alteração na estrutura de cargos. Os entrevistados E3, E4, E6 e E9 mencionaram que houve a criação de novos cargos, tais como UX, PO, SM e AE, porém, apenas os funcionários contratados após o início da transição receberam tais denominações, demandando, inclusive, o perfil multidisciplinar que o modelo ágil prevê. Os demais profissionais da organização, contratados anteriormente à transição, tiveram que se adaptar a estes novos papéis e responsabilidades, agregando funções que antes não lhes eram atribuídas (Quadro 35).

Quadro 35 - Análise da coleta de dados: Estrutura hierárquica - Alteração na estrutura de cargos

\begin{tabular}{|c|c|c|c|c|}
\hline \multirow{4}{*}{ 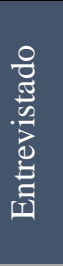 } & Unidade de Análise 22 & \multicolumn{3}{|l|}{ Estrutura hierárquica } \\
\hline & Questão & \multicolumn{3}{|c|}{$\begin{array}{l}\text { Q15: Quais os impactos na estrutura de cargos da empresa e níveis } \\
\text { hierárquicos? }\end{array}$} \\
\hline & Subunidade & \multicolumn{3}{|c|}{ Alteração na estrutura de cargos } \\
\hline & Mensagem principal & $\begin{array}{l}\text { Interpretação da } \\
\text { mensagem principal }\end{array}$ & Mensagem associada & $\begin{array}{l}\text { Interpretação da } \\
\text { mensagem associada }\end{array}$ \\
\hline E1 & $\begin{array}{l}\text { "Por enquanto, não } \\
\text { mudou nada nos cargos, } \\
\text { acho que isso vai } \\
\text { demorar porque a } \\
\text { empresa é bem } \\
\text { tradicional, com uma } \\
\text { hierarquia forte". }\end{array}$ & $\begin{array}{l}\text { Não houve alteração na } \\
\text { estrutura de cargos da } \\
\text { organização. }\end{array}$ & & \\
\hline E3 & $\begin{array}{l}\text { "Antes era Engenheiro } \\
\text { de Produtos e agora } \\
\text { virou PO. Antes era } \\
\text { PMO e agora virou AE, } \\
\text { que é o Agile Expert. } \\
\text { Então, nesse aspecto, } \\
\text { acho que realmente só } \\
\text { foi o nome mesmo". }\end{array}$ & $\begin{array}{l}\text { Houve a renomeação de } \\
\text { cargos na organização. }\end{array}$ & & \\
\hline E4 & $\begin{array}{l}\text { "Acabou só } \\
\text { renomeando os cargos. } \\
\text { Então, pessoas que já } \\
\text { estavam na coordenação } \\
\text { viraram Scrum Masters, } \\
\text { viraram PO's". }\end{array}$ & $\begin{array}{l}\text { Houve a renomeação de } \\
\text { cargos na organização. }\end{array}$ & $\begin{array}{l}\text { "As atividades acabaram } \\
\text { não mudando muito, } \\
\text { coordenadores que já } \\
\text { faziam o papel de } \\
\text { coordenação viraram } \\
\text { Scrum Masters só no } \\
\text { nome". }\end{array}$ & $\begin{array}{l}\text { Não houve mudança de } \\
\text { papéis e nem de } \\
\text { responsabilidades. }\end{array}$ \\
\hline E5 & $\begin{array}{l}\text { "Não existe um job } \\
\text { description... são coisas } \\
\text { que a gente quer que } \\
\text { sejam feitas este ano". }\end{array}$ & $\begin{array}{l}\text { Não houve alteração na } \\
\text { estrutura de cargos da } \\
\text { organização. }\end{array}$ & & \\
\hline E6 & $\begin{array}{l}\text { "No primeiro momento } \\
\text { foi só job description e } \\
\text { criação de novos cargos. } \\
\text { O PO que não tinha, o } \\
\text { SM que não tinha, o } \\
\text { Agile Coach que } \\
\text { entrou". }\end{array}$ & $\begin{array}{l}\text { Houve a renomeação e } \\
\text { criação de novos cargos } \\
\text { na organização. }\end{array}$ & & \\
\hline E7 & $\begin{array}{l}\text { "Você mudou só ali a } \\
\text { sua função, mas o cargo } \\
\text { mesmo ficou o que } \\
\text { estava na carteira". }\end{array}$ & $\begin{array}{l}\text { Houve a mudança de } \\
\text { função, sem a } \\
\text { renomeação efetiva do } \\
\text { cargo. }\end{array}$ & & (Continua) \\
\hline
\end{tabular}




\begin{tabular}{|c|c|c|c|c|}
\hline \multirow{4}{*}{ 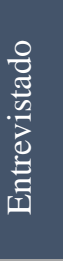 } & Unidade de Análise 22 & \multicolumn{3}{|c|}{ Estrutura hierárquica (Continuação) } \\
\hline & Questão & \multicolumn{3}{|c|}{$\begin{array}{l}\text { Q15: Quais os impactos na estrutura de cargos da empresa e níveis } \\
\text { hierárquicos? }\end{array}$} \\
\hline & Subunidade & \multicolumn{3}{|c|}{ Alteração na estrutura de cargos } \\
\hline & Mensagem principal & $\begin{array}{c}\text { Interpretação da } \\
\text { mensagem principal }\end{array}$ & Mensagem associada & $\begin{array}{c}\text { Interpretação da } \\
\text { mensagem associada }\end{array}$ \\
\hline E8 & $\begin{array}{l}\text { "Não teve mudança, } \\
\text { foram ganhando os } \\
\text { papéis". }\end{array}$ & $\begin{array}{l}\text { Houve a mudança de } \\
\text { função, sem a } \\
\text { renomeação efetiva do } \\
\text { cargo. }\end{array}$ & $\begin{array}{l}\text { "Foi uma transição } \\
\text { assim: as pessoas foram } \\
\text { embora e vieram os } \\
\text { novos". }\end{array}$ & $\begin{array}{l}\text { A mudança de cargos foi } \\
\text { resultado do turnover da } \\
\text { organização. }\end{array}$ \\
\hline E9 & $\begin{array}{l}\text { "Os cargos do mundo } \\
\text { digital não existiam... } \\
\text { O cargo de PO não } \\
\text { existia, o cargo de UX } \\
\text { não existia. Então sim, } \\
\text { mudou a estrutura de } \\
\text { cargos". }\end{array}$ & $\begin{array}{l}\text { Houve a criação de } \\
\text { novos cargos na } \\
\text { organização. }\end{array}$ & & \\
\hline E10 & $\begin{array}{l}\text { "São funções e não } \\
\text { cargos... A } \\
\text { coordenadora de } \\
\text { negócio da área de } \\
\text { Marketing é a PO do } \\
\text { meu projeto. A analista } \\
\text { de processos da área de } \\
\text { Produtos é uma outra } \\
\text { PO". }\end{array}$ & $\begin{array}{l}\text { Houve a mudança de } \\
\text { função, sem a } \\
\text { renomeação efetiva do } \\
\text { cargo. }\end{array}$ & $\begin{array}{l}\text { "A estrutura é } \\
\text { hierarquizada, eles só } \\
\text { trocaram o nome para } \\
\text { parecer ágil". }\end{array}$ & $\begin{array}{l}\text { Não houve mudança de } \\
\text { papéis e nem de } \\
\text { responsabilidades. }\end{array}$ \\
\hline MP & \multicolumn{4}{|c|}{$\begin{array}{l}\text { Na maioria das vezes, as organizações apenas renomearam os cargos anteriores para os novos cargos } \\
\text { ágeis, sem um treinamento adequado dos novos papéis e responsabilidades ou o apoio da equipe de } \\
\text { Change Management para acompanhar os impactos destas mudanças. Outra forma não tão nobre } \\
\text { percebida nas organizações foi a formação de novas equipes através da demissão ou do turnover dos } \\
\text { funcionários com os cargos anteriores e as novas contratações sendo realizadas para os novos cargos } \\
\text { ágeis. Esta opção impacta na curva de conhecimento e na motivação da equipe, criando uma } \\
\text { diferenciação entre os funcionários atuais e os novos. }\end{array}$} \\
\hline
\end{tabular}

Fonte: Quadro elaborado pela autora, com base nas entrevistas.

c) Criação da área de Transformação Digital

Quatro dos entrevistados (E6, E7, E9 e E10) informaram que foi criada uma área de Transformação Digital internamente na organização, responsável pelo desenvolvimento de alguns produtos de inovação. Dois destes entrevistados (E6 e E9) informaram que esta área também era responsável pela governança dos processos, pelo escritório de projetos e pela transição do modelo tradicional para o ágil. Além deles, dois outros entrevistados de uma mesma organização (E1 e E5) relataram a existência de uma área de Transformação Digital contendo apenas a governança dos processos, sem a responsabilidade de execução dos projetos (Quadro 36). 
Quadro 36 - Análise da coleta de dados: Estrutura hierárquica - Criação da área de Transformação Digital

\begin{tabular}{|c|c|c|c|c|}
\hline \multirow{4}{*}{ 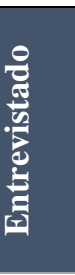 } & Unidade de Análise 22 & \multicolumn{3}{|l|}{ Estrutura hierárquica } \\
\hline & Questão & \multicolumn{3}{|c|}{$\begin{array}{l}\text { Q15: Quais os impactos na estrutura de cargos da empresa e níveis } \\
\text { hierárquicos? }\end{array}$} \\
\hline & Subunidade & \multicolumn{3}{|c|}{ Criação da área de Transformação Digital } \\
\hline & Mensagem principal & $\begin{array}{l}\text { Interpretação da } \\
\text { mensagem principal }\end{array}$ & Mensagem associada & $\begin{array}{c}\text { Interpretação da } \\
\text { mensagem associada }\end{array}$ \\
\hline E1 & $\begin{array}{l}\text { "Foi definida uma } \\
\text { equipe interna de } \\
\text { transformação que } \\
\text { incluía a área de PMO, } \\
\text { de TI e uma equipe } \\
\text { multidisciplinar que } \\
\text { lidera o projeto de } \\
\text { Transformação Ágil na } \\
\text { companhia... A equipe } \\
\text { interna é alinhada com a } \\
\text { consultoria e eles são } \\
\text { responsáveis por fazer o } \\
\text { contato com as outras } \\
\text { equipes da empresa". }\end{array}$ & $\begin{array}{l}\text { Foi criada uma área de } \\
\text { Transformação Digital } \\
\text { internamente na } \\
\text { organização, } \\
\text { responsável pela } \\
\text { governança dos } \\
\text { processos e pela } \\
\text { transição do modelo } \\
\text { tradicional para o ágil. }\end{array}$ & & \\
\hline $\mathbf{E 5}$ & $\begin{array}{l}\text { "A gente... criou o } \\
\text { LACE (Lean Agile } \\
\text { Center of Excellence), } \\
\text { que é o grupo de } \\
\text { transformação". }\end{array}$ & $\begin{array}{l}\text { Foi criada uma área de } \\
\text { Transformação Digital } \\
\text { internamente na } \\
\text { organização, } \\
\text { responsável pela } \\
\text { governança dos } \\
\text { processos e pela } \\
\text { transição do modelo } \\
\text { tradicional para o ágil. }\end{array}$ & & \\
\hline E6 & $\begin{array}{l}\text { "O PMO respondia para } \\
\text { a diretoria de } \\
\text { Desenvolvimento } \\
\text { Organizacional. Eu } \\
\text { estava abaixo da } \\
\text { Diretoria de TI, como a } \\
\text { maioria, e depois eu fui } \\
\text { para a Diretoria de DO". }\end{array}$ & $\begin{array}{l}\text { Foi criada uma área de } \\
\text { Transformação Digital } \\
\text { internamente na } \\
\text { organização, } \\
\text { responsável pelo } \\
\text { desenvolvimento de } \\
\text { alguns produtos de } \\
\text { inovação e de } \\
\text { governança dos } \\
\text { processos e também } \\
\text { pela transição do } \\
\text { modelo tradicional para } \\
\text { o ágil. Esta área estava } \\
\text { na mesma estrutura do } \\
\text { RH. }\end{array}$ & & \\
\hline E7 & $\begin{array}{l}\text { "O piloto tinha sido o } \\
\text { Digital... Eles cuidavam } \\
\text { do App... Ganhou muita } \\
\text { visibilidade porque } \\
\text { estava trazendo muito } \\
\text { retorno". }\end{array}$ & $\begin{array}{l}\text { Foi criada uma área de } \\
\text { Digital internamente na } \\
\text { organização, } \\
\text { responsável pelo } \\
\text { desenvolvimento de } \\
\text { alguns produtos de } \\
\text { inovação (aplicativo). }\end{array}$ & & \\
\hline
\end{tabular}

(Continua) 


\begin{tabular}{|c|c|c|c|c|}
\hline \multirow{4}{*}{ 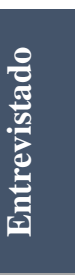 } & Unidade de Análise 22 & \multicolumn{3}{|c|}{ Estrutura hierárquica (Continuação) } \\
\hline & Questão & \multicolumn{3}{|c|}{$\begin{array}{l}\text { Q15: Quais os impactos na estrutura de cargos da empresa e níveis } \\
\text { hierárquicos? }\end{array}$} \\
\hline & Subunidade & \multicolumn{3}{|c|}{ Criação da área de Transformação Digital } \\
\hline & Mensagem principal & $\begin{array}{l}\text { Interpretação da } \\
\text { mensagem principal }\end{array}$ & Mensagem associada & $\begin{array}{l}\text { Interpretação da } \\
\text { mensagem associada }\end{array}$ \\
\hline E9 & $\begin{array}{l}\text { "O banco contratou um } \\
\text { diretor para formar uma } \\
\text { área específica de } \\
\text { Digital... Eu sou... } \\
\text { Digital Transformation } \\
\text { Leader, ou seja, eu } \\
\text { garanto a governança de } \\
\text { todas as tribos fim a fim, } \\
\text { e a garantia do método". }\end{array}$ & $\begin{array}{l}\text { Foi criada uma área de } \\
\text { Transformação Digital } \\
\text { internamente na } \\
\text { organização, } \\
\text { responsável pelo } \\
\text { desenvolvimento de } \\
\text { alguns produtos de } \\
\text { inovação (site e } \\
\text { aplicativo), além da } \\
\text { governança dos } \\
\text { processos, responsável } \\
\text { pela transição do } \\
\text { modelo tradicional para } \\
\text { o ágil. }\end{array}$ & $\begin{array}{l}\text { "Nosso CEO contratou } \\
\text { um diretor para uma } \\
\text { diretoria nova de } \\
\text { Transformação } \\
\text { Organizacional. A } \\
\text { diretoria dele tem abaixo } \\
3 \text { superintendências: } \\
\text { uma de Capital Humano, } \\
\text { que é RH; outra de } \\
\text { Cultura; e outra de } \\
\text { Governança ágil". }\end{array}$ & $\begin{array}{l}\text { Houve a mudança de } \\
\text { estrutura. Foi criada } \\
\text { uma nova diretoria, } \\
\text { incluindo a área de } \\
\text { Recursos Humanos e } \\
\text { permeando todas as } \\
\text { áreas da organização. }\end{array}$ \\
\hline E10 & $\begin{array}{l}\text { "Existe uma área da } \\
\text { companhia, o Digital, } \\
\text { que faz o site, e essa } \\
\text { área é toda ágil". }\end{array}$ & $\begin{array}{l}\text { Foi criada uma área de } \\
\text { Digital internamente na } \\
\text { organização, } \\
\text { responsável pelo } \\
\text { desenvolvimento de } \\
\text { alguns produtos de } \\
\text { inovação (site e } \\
\text { aplicativo). }\end{array}$ & & \\
\hline MP & \multicolumn{4}{|c|}{$\begin{array}{l}\text { A criação de uma área de Transformação Digital é importante para realizar a comunicação e o } \\
\text { acompanhamento da transição, os treinamentos e a definição dos novos processos ágeis. O ideal é que o } \\
\text { RH ou a equipe de Change Management também façam parte desta equipe geral, para que avaliem o } \\
\text { impacto causado nas pessoas durante esta transição. Em alguns casos, esta área também é responsável } \\
\text { pelo piloto de Transformação Digital, criado internamente na organização, incorporando o } \\
\text { desenvolvimento de produtos. Porém, a existência de um processo diferenciado para os produtos digitais } \\
\text { pode gerar culturas diferenciadas dentro da organização. }\end{array}$} \\
\hline
\end{tabular}

Fonte: Quadro elaborado pela autora, com base nas entrevistas.

\subsubsection{Treinamento - coleta de dados primários (UA 23)}

a)

\section{Realização do Treinamento}

A capacitação dos funcionários nos processos e valores ágeis é um dos principais fatores de sucesso da transição. A recomendação é, portanto, que sejam realizados treinamentos nas novas competências comportamentais que a equipe deverá assumir (soft skills) e no negócio da organização. Por isso, é essencial a participação da equipe de Recursos Humanos ou de uma equipe específica de Change Management.

Todos os entrevistados relataram que a organização realizou algum tipo de treinamento, geralmente incluindo os frameworks Scrum e Kanban e abordando princípios, papéis e responsabilidades do modelo ágil. Na maioria das vezes, os treinamentos foram 
organizados pela área responsável pela transformação ágil na organização ou pela consultoria contratada, e correspondiam a um passo da transformação. Em alguns casos, os treinamentos foram faseados e diversificados, geralmente iniciando por vídeos e, posteriormente, utilizando um método mais imersivo. Três dos entrevistados (E6, E7 e E9) mencionaram também a realização de treinamentos para a definição de produto, tais como Design Thinking e Inception. O entrevistado E9 mencionou também o treinamento de OKR.

Apenas quatro dos entrevistados (E2, E4, E5 e E6) mencionaram que ocorreram aos treinamentos de soft skills, sendo, em um dos casos (E4), oferecido apenas para a liderança da organização. No caso do entrevistado E6, houve uma maior preocupação quanto a esses treinamentos do que quanto aos do próprio modelo ágil. O entrevistado E10 mencionou que faltou um treinamento estruturado na organização sobre os valores ágeis, resultando em uma descrença da aplicação do modelo pela maioria das áreas. Além disso, os treinamentos realizados posteriormente, como o de $\mathrm{SAFe}$, geraram uma maior insatisfação dos funcionários, por não poderem aplicar estas práticas internamente na organização (Quadro 37).

Quadro 37 - Análise da coleta de dados: Treinamento

\begin{tabular}{|c|c|c|c|c|}
\hline \multirow{3}{*}{ 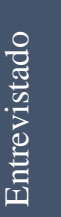 } & Unidade de Análise 23 & \multicolumn{3}{|l|}{ Treinamento } \\
\hline & Questão & \multicolumn{3}{|c|}{$\begin{array}{l}\text { Q11: Houve treinamento da equipe em novas habilidades (metodologia ágil, } \\
\text { negócio, soft skills)? }\end{array}$} \\
\hline & Mensagem principal & $\begin{array}{l}\text { Interpretação da } \\
\text { mensagem principal }\end{array}$ & Mensagem associada & $\begin{array}{l}\text { Interpretação da } \\
\text { mensagem associada }\end{array}$ \\
\hline E1 & $\begin{array}{l}\text { "Teve treinamento de } \\
\text { Fundamentos Ágeis, } \\
\text { sobre a metodologia, } \\
\text { para alinhamento do } \\
\text { conhecimento. Então, } \\
\text { teve curso de Scrum } \\
\text { Master, de PO e } \\
\text { Kanban... As áreas de } \\
\text { negócio, de } \\
\text { desenvolvimento e o } \\
\text { PMO participaram". }\end{array}$ & $\begin{array}{l}\text { Houve treinamento nos } \\
\text { métodos ágeis para as } \\
\text { equipes do projeto. }\end{array}$ & & \\
\hline E2 & $\begin{array}{l}\text { "Para quem estava na } \\
\text { época envolvido } \\
\text { diretamente com projeto, } \\
\text { ou sendo ponto focal de } \\
\text { projeto ou sendo AE, } \\
\text { PO, BO, todos tiveram } \\
\text { treinamentos". }\end{array}$ & $\begin{array}{l}\text { Houve treinamento nos } \\
\text { métodos ágeis para as } \\
\text { equipes do projeto. }\end{array}$ & $\begin{array}{l}\text { "Toda vez que a gente } \\
\text { vai lançar um squad, tem } \\
\text { uma agenda de } \\
\text { treinamentos, então aí } \\
\text { passa um pouco de team } \\
\text { building também... } \\
\text { sobre o método em si, } \\
\text { papéis e } \\
\text { responsabilidades, até } \\
\text { parte trabalhista é } \\
\text { falada". }\end{array}$ & $\begin{array}{l}\text { Os treinamentos eram } \\
\text { realizados no } \\
\text { lançamento de cada } \\
\text { squad, incluindo } \\
\text { metodologia e soft } \\
\text { skills. }\end{array}$ \\
\hline
\end{tabular}




\begin{tabular}{|c|c|c|c|c|}
\hline \multirow{3}{*}{ 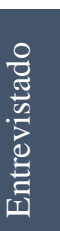 } & Unidade de Análise 23 & \multicolumn{3}{|c|}{ Treinamento (Continuação) } \\
\hline & Questão & \multicolumn{3}{|c|}{$\begin{array}{l}\text { Q11: Houve treinamento da equipe em novas habilidades (metodologia ágil, } \\
\text { negócio, soft skills)? }\end{array}$} \\
\hline & Mensagem principal & $\begin{array}{c}\text { Interpretação da } \\
\text { mensagem principal }\end{array}$ & Mensagem associada & $\begin{array}{c}\text { Interpretação da } \\
\text { mensagem associada }\end{array}$ \\
\hline $\mathbf{E 3}$ & $\begin{array}{l}\text { "A gente fez } \\
\text { treinamento... de como } \\
\text { seria a metodologia... } \\
\text { Treinamento isso } \\
\text { realmente tem... só da } \\
\text { metodologia do dia a dia } \\
\text { mesmo, dos ritos, papéis } \\
\text { e responsabilidades". }\end{array}$ & $\begin{array}{l}\text { Houve treinamento nos } \\
\text { métodos ágeis para as } \\
\text { equipes do projeto. }\end{array}$ & & \\
\hline E4 & $\begin{array}{l}\text { "Na primeira } \\
\text { transformação... cada } \\
\text { vídeo apresentava uma } \\
\text { prática... No caso da } \\
\text { segunda que teve com o } \\
\text { Kanban... eram cinco } \\
\text { dias de treinamento... } \\
\text {...[De soft skills] eles } \\
\text { começaram a dar esses } \\
\text { treinamentos para a } \\
\text { liderança. Então teve } \\
\text { diferentes modelos". }\end{array}$ & $\begin{array}{l}\text { Houve treinamento nos } \\
\text { métodos ágeis para as } \\
\text { equipes do projeto. Soft } \\
\text { skills apenas para a } \\
\text { liderança. }\end{array}$ & $\begin{array}{l}\text { "A gente começou a } \\
\text { fazer isso em escala... } \\
\text { eram } 5000 \text { pessoas. A } \\
\text { gente treinava uns } 6 \\
\text { times por semana". }\end{array}$ & $\begin{array}{l}\text { Houve treinamento em } \\
\text { escalas para todos da } \\
\text { organização (de grande } \\
\text { porte). }\end{array}$ \\
\hline E5 & $\begin{array}{l}\text { "A gente tem um } \\
\text { catálogo de treinamen- } \\
\text { tos... fundamentos de } \\
\text { ágil... Kanban... } \\
\text { Extreme Programming, e } \\
\text { ferramental... Soft skills } \\
\text { ficam mais a cargo de } \\
\text { RH". }\end{array}$ & $\begin{array}{l}\text { Houve treinamento nos } \\
\text { métodos ágeis para as } \\
\text { equipes do projeto. Soft } \\
\text { skills não fazem parte } \\
\text { do catálogo de } \\
\text { treinamento da } \\
\text { transição ágil. }\end{array}$ & & \\
\hline E6 & $\begin{array}{l}\text { "A gente teve... uma } \\
\text { trilha de capacitação bem } \\
\text { definida... treinamento } \\
\text { de Scrum no terceiro mês } \\
\text { do projeto... No primeiro } \\
\text { momento, a gente falou } \\
\text { de times altamente } \\
\text { capazes. A gente foi } \\
\text { mais para o lado de } \\
\text { cultura, de alta } \\
\text { performance, de } \\
\text { inteligência emocional, } \\
\text { do que propriamente } \\
\text { Guide... A gente queria } \\
\text { construir o nosso Guide e } \\
\text { dar treinamento sobre o } \\
\text { nosso Guide". }\end{array}$ & $\begin{array}{l}\text { Houve primeiramente } \\
\text { treinamento em soft } \\
\text { skills e depois nos } \\
\text { métodos ágeis, já } \\
\text { adaptados ao contexto } \\
\text { da organização. }\end{array}$ & $\begin{array}{l}\text { "Tinha a parte de } \\
\text { Produtos, Negócios, } \\
\text { Inception, ciclo de vida } \\
\text { do produto, como você } \\
\text { montar um roadmap, } \\
\text { times de alta } \\
\text { performance, soft skills". }\end{array}$ & $\begin{array}{l}\text { O escopo dos } \\
\text { treinamentos ia além } \\
\text { dos métodos ágeis, } \\
\text { incluindo também o } \\
\text { ciclo de vida do produto } \\
\text { e soft skills. }\end{array}$ \\
\hline E7 & $\begin{array}{l}\text { "Eles deram vários } \\
\text { treinamentos sobre o } \\
\text { scrum... depois eles } \\
\text { começaram a introduzir } \\
\text { o Kanban". }\end{array}$ & $\begin{array}{l}\text { Houve treinamento nos } \\
\text { métodos ágeis para as } \\
\text { equipes do projeto. }\end{array}$ & $\begin{array}{l}\text { "Eles têm uma outra } \\
\text { linha... de workshops } \\
\text { para outras empresas } \\
\text { virem na sua empresa. } \\
\text { Eu mesma participei de } \\
\text { um curso de Design } \\
\text { Thinking, que era um } \\
\text { conhecimento a mais, } \\
\text { que não era obrigatório". }\end{array}$ & $\begin{array}{l}\text { O escopo dos } \\
\text { treinamentos ia além } \\
\text { dos métodos ágeis, } \\
\text { incluindo também o } \\
\text { ciclo de vida do } \\
\text { produto. }\end{array}$ \\
\hline
\end{tabular}




\begin{tabular}{|c|c|c|c|c|}
\hline \multirow{3}{*}{ 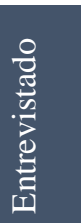 } & Unidade de Análise 23 & \multicolumn{3}{|c|}{ Treinamento (Continuação) } \\
\hline & Questão & \multicolumn{3}{|c|}{$\begin{array}{l}\text { Q11: Houve treinamento da equipe em novas habilidades (metodologia ágil, } \\
\text { negócio, soft skills)? }\end{array}$} \\
\hline & Mensagem principal & $\begin{array}{l}\text { Interpretação da } \\
\text { mensagem principal }\end{array}$ & Mensagem associada & $\begin{array}{l}\text { Interpretação da } \\
\text { mensagem associada }\end{array}$ \\
\hline E8 & $\begin{array}{l}\text { "Não tivemos } \\
\text { [treinamento de scrum]. } \\
\text { Cada um trouxe do seu } \\
\text { antigo trabalho". }\end{array}$ & $\begin{array}{l}\text { Não houve treinamento } \\
\text { nos métodos ágeis. } \\
\text { Houve contratação de } \\
\text { pessoas com o } \\
\text { conhecimento. }\end{array}$ & $\begin{array}{l}\text { "A gente fez algumas } \\
\text { coisas de cultura } \\
\text { organizacional, depois a } \\
\text { gente falou do } \\
\text { Manifesto... conceitos de } \\
\text { backlog... a gente } \\
\text { começou um } \\
\text { treinamento de liderança } \\
\text { agora... Foi só } \\
\text { tecnologia mesmo, junto } \\
\text { com o Agile Coach". }\end{array}$ & $\begin{array}{l}\text { O Agile Coach } \\
\text { ministrava treinamentos } \\
\text { sob demanda para o } \\
\text { time, à medida que iam } \\
\text { sendo identificadas as } \\
\text { necessidades. }\end{array}$ \\
\hline E9 & $\begin{array}{l}\text { "Técnicas ágeis, de } \\
\text { cerimônias, de OKRs... } \\
\text { como fazer Inception... } \\
\text { Design Thinking... } \\
\text { Kanban... a gente botou } \\
\text { quem não tinha } \\
\text { certificação para fazer } \\
\text { certificação... os Agile } \\
\text { Coaches... dão } \\
\text { treinamentos on the job } \\
\text { constantes e } \\
\text { treinamentos específicos } \\
\text { também". }\end{array}$ & $\begin{array}{l}\text { Houve treinamento nos } \\
\text { métodos ágeis, ciclo de } \\
\text { vida do produto, ágil } \\
\text { escalado, entre outros. } \\
\text { Não houve treinamento } \\
\text { em soft skills. }\end{array}$ & $\begin{array}{l}\text { "Focado nas pessoas que } \\
\text { estão no Digital". }\end{array}$ & $\begin{array}{l}\text { Os treinamentos eram } \\
\text { apenas para a equipe do } \\
\text { Digital, sem dar a } \\
\text { oportunidade de } \\
\text { conhecimento para as } \\
\text { demais áreas não } \\
\text { migradas. }\end{array}$ \\
\hline E10 & $\begin{array}{l}\text { "Banho de loja, nada... A } \\
\text { equipe do Escritório de } \\
\text { Projetos, pagou } \\
\text { certificação de } \\
\text { Management } 3.0 \text { e SAFe } \\
\text { para todo o time. Só que } \\
\text { o que eu brinco é que } \\
\text { eles escalaram um time } \\
\text { tradicional". }\end{array}$ & $\begin{array}{l}\text { Não houve treinamento } \\
\text { nos métodos ágeis, } \\
\text { porém houve } \\
\text { treinamento no ágil } \\
\text { escalado. }\end{array}$ & $\begin{array}{l}\text { "As pessoas não } \\
\text { implantavam o que a } \\
\text { gente certificou, e } \\
\text { começaram a sair". }\end{array}$ & $\begin{array}{l}\text { Alto turnover devido à } \\
\text { impossibilidade de } \\
\text { aplicação dos conceitos } \\
\text { obtidos nos } \\
\text { treinamentos. }\end{array}$ \\
\hline MP & \multicolumn{4}{|c|}{$\begin{array}{l}\text { Como o modelo ágil causa um grande impacto nas pessoas, deve-se tomar cuidado para que elas sejam } \\
\text { treinadas em relação aos novos papéis e responsabilidades que irão assumir. Porém, a maioria das } \\
\text { organizações focou apenas nos treinamentos relacionados aos novos processos e aos papéis e } \\
\text { responsabilidades, sem abordar competências comportamentais. As organizações que não ofereceram } \\
\text { treinamentos adequados foram as que sofreram maior resistência na aplicação das práticas ágeis, } \\
\text { principalmente quanto ao apoio da gestão e à integração com as demais áreas. }\end{array}$} \\
\hline
\end{tabular}

Fonte: Quadro elaborado pela autora, com base nas entrevistas.

b) Participação de Recursos Humanos

A transformação ágil demanda a atuação da área de Recursos Humanos da organização, porém, na prática, nem sempre isto ocorre. Sete dos entrevistados (E1, E2, E3, E5, E6, E7 e E9) mencionaram que houve participação do RH durante o processo de transformação ágil, porém, em apenas três casos (E6, E9 e E5) esta atuação foi realmente 
efetiva: os entrevistados E6 e E9 informaram que a área de Transformação Digital fazia parte da área de Recursos Humanos e o entrevistado E5 informou que existia um representante do RH na área de Transformação Digital (LACE). O entrevistado E2, por sua vez, mencionou que houve uma participação tímida do RH durante a transformação ágil, devido à alocação de recursos sem experiência neste processo. Por fim, o entrevistado E7 relatou que a participação do RH ocorreu devido à necessidade de demissão e de contratação de funcionários de forma massiva e não para apoiar o processo de transição (Quadro 38).

Quadro 38 - Análise da coleta de dados: Treinamento - Participação de Recursos Humanos

\begin{tabular}{|c|c|c|c|c|}
\hline \multirow{4}{*}{ 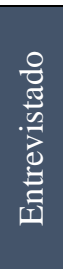 } & Unidade de Análise 23 & \multicolumn{3}{|l|}{ Treinamento } \\
\hline & Questão & \multicolumn{3}{|c|}{$\begin{array}{l}\text { Q10: Houve participação da área de Recursos Humanos ou de Change } \\
\text { Management durante a transição? }\end{array}$} \\
\hline & Subunidade & \multicolumn{3}{|c|}{ Participação de Recursos Humanos } \\
\hline & Mensagem principal & $\begin{array}{l}\text { Interpretação da } \\
\text { mensagem principal }\end{array}$ & Mensagem associada & $\begin{array}{l}\text { Interpretação da } \\
\text { mensagem associada }\end{array}$ \\
\hline E1 & $\begin{array}{l}\text { "Tem um gestor do RH } \\
\text { cuidando do processo... } \\
\text { O RH apoia muito na } \\
\text { disseminação dos } \\
\text { treinamentos". }\end{array}$ & $\begin{array}{l}\text { Houve participação do } \\
\text { RH na transição ágil, } \\
\text { principalmente na } \\
\text { aplicação de } \\
\text { treinamentos. }\end{array}$ & & \\
\hline E2 & $\begin{array}{l}\text { "A gente tem uma área } \\
\text { de Change } \\
\text { Management... Eles } \\
\text { poderiam ter sido muito } \\
\text { mais protagonistas nesse } \\
\text { processo... Pegamos } \\
\text { pessoas e... colocamos } \\
\text { em uma função... Não } \\
\text { que tivesse vivido o } \\
\text { processo de } \\
\text { transformação digital". }\end{array}$ & $\begin{array}{l}\text { A área de Change } \\
\text { Management não estava } \\
\text { preparada para apoiar a } \\
\text { transição, pois não tinha } \\
\text { conhecimento necessário } \\
\text { quanto ao mercado. }\end{array}$ & & \\
\hline $\mathbf{E 3}$ & $\begin{array}{l}\text { "Teve um movimento de } \\
\text { RH... falando da } \\
\text { transformação para o } \\
\text { digital". }\end{array}$ & $\begin{array}{l}\text { Houve participação do } \\
\text { RH na transição ágil. }\end{array}$ & & \\
\hline E4 & $\begin{array}{l}\text { "RH participou, mas no } \\
\text { sentido de aplicar lá } \\
\text { também, mas não deles } \\
\text { participarem do processo } \\
\text { com a gente. }\end{array}$ & $\begin{array}{l}\text { O RH participou da } \\
\text { transição como área } \\
\text { impactada e não } \\
\text { apoiando o processo. }\end{array}$ & & \\
\hline E5 & $\begin{array}{l}\text { "Tem uma pessoa do RH } \\
\text { no LACE... avaliação de } \\
\text { desempenho... plano de } \\
\text { carreira, descrição de } \\
\text { cargo, faixa salarial, } \\
\text { treinamento... Parte } \\
\text { cultural é outra coisa que } \\
\text { a gente também quer } \\
\text { envolver, contratação". }\end{array}$ & $\begin{array}{l}\text { Houve participação do } \\
\text { RH na transição ágil, na } \\
\text { aplicação de } \\
\text { treinamentos, no plano } \\
\text { de carreira, na avaliação } \\
\text { de desempenho etc. }\end{array}$ & & \\
\hline
\end{tabular}




\begin{tabular}{|c|c|c|c|c|}
\hline \multirow{4}{*}{ 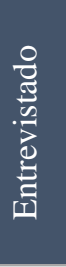 } & Unidade de Análise 23 & \multicolumn{3}{|c|}{ Treinamento (Continuação) } \\
\hline & Questão & \multicolumn{3}{|c|}{$\begin{array}{l}\text { Q10: Houve participação da área de Recursos Humanos ou de Change } \\
\text { Management durante a transição? }\end{array}$} \\
\hline & Subunidade & \multicolumn{3}{|c|}{ Participação de Recursos Humanos } \\
\hline & Mensagem principal & $\begin{array}{l}\text { Interpretação da } \\
\text { mensagem principal }\end{array}$ & Mensagem associada & $\begin{array}{l}\text { Interpretação da } \\
\text { mensagem associada }\end{array}$ \\
\hline E6 & $\begin{array}{l}\text { "O PMO respondia para } \\
\text { a diretoria de } \\
\text { Desenvolvimento } \\
\text { Organizacional". }\end{array}$ & $\begin{array}{l}\text { A área responsável pela } \\
\text { transição ágil respondia } \\
\text { para a equipe de } \\
\text { Desenvolvimento } \\
\text { Organizacional } \\
\text { (Recursos Humanos). }\end{array}$ & & \\
\hline E7 & $\begin{array}{l}\text { "O RH sempre esteve } \\
\text { muito próximo, porque } \\
\text { como teve uma demissão } \\
\text { em massa e uma } \\
\text { contratação em massa... } \\
\text { as pessoas que não } \\
\text { aderiram e foram } \\
\text { desligadas, mas também } \\
\text { teve uma absorção de } \\
\text { terceiros muito grande. } \\
\text { Então, o RH foi chamado } \\
\text { para fazer essa transição } \\
\text { junto com tecnologia". }\end{array}$ & $\begin{array}{l}\text { Houve participação do } \\
\text { RH na demissão dos } \\
\text { funcionários que não se } \\
\text { adaptaram ao novo } \\
\text { modelo e também na } \\
\text { contratação massiva dos } \\
\text { terceiros. }\end{array}$ & & \\
\hline E8 & $\begin{array}{l}\text { "Não, não teve. Foi só } \\
\text { tecnologia mesmo". }\end{array}$ & $\begin{array}{l}\text { Não houve a } \\
\text { participação do RH na } \\
\text { transição ágil. }\end{array}$ & & \\
\hline E9 & $\begin{array}{l}\text { "O nosso CEO contratou } \\
\text { um diretor para uma } \\
\text { diretoria nova de } \\
\text { Transformação } \\
\text { Organizacional. A } \\
\text { diretoria dele tem abaixo } \\
\text { três superintendências: } \\
\text { uma de Capital Humano, } \\
\text { que é o RH, outra de } \\
\text { Cultura, e outra de } \\
\text { Governança Ágil". }\end{array}$ & $\begin{array}{l}\text { A área responsável pela } \\
\text { transição ágil está na } \\
\text { mesma estrutura } \\
\text { organizacional de } \\
\text { Recursos Humanos. }\end{array}$ & & \\
\hline MP & \multicolumn{4}{|c|}{$\begin{array}{l}\text { A participação da área de RH ou de uma equipe de Change Management durante a transição ágil é de } \\
\text { extrema importância para apoiar as transformações culturais da organização, tais como a adaptação das } \\
\text { equipes aos novos papéis e responsabilidades e a aceitação do novo modelo de tomada de decisões } \\
\text { descentralizada pelos executivos. Porém, a maioria dos entrevistados relatou que não houve a } \\
\text { participação do RH ou que ela não foi efetiva no acompanhamento das pessoas durante a transição. }\end{array}$} \\
\hline
\end{tabular}

Fonte: Quadro elaborado pela autora, com base nas entrevistas.

\subsection{MAPEAMENTO DOS DESAFIOS E RECOMENDAÇÕES COM BASE NA COLETA DE DADOS}

Além das questões relacionadas especificamente com as Unidades de Análise identificadas na RSL, foram feitas duas outras perguntas adicionais aos entrevistados, a fim de possibilitar o mapeamento de suas percepções em relação aos principais desafios e recomendações encontrados em suas respectivas organizações. São elas: 
- Q25: Quais foram os maiores desafios da transformação ágil?

- Q30: Qual recomendação você daria para as organizações que estão iniciando o processo de transformação ágil?

Em relação à pergunta $\mathrm{Q} 25$, o desafio mencionado pela maioria dos entrevistados foi $\mathrm{o}$ engajamento das equipes, devido à:

- resistência dos gestores em ceder os membros da sua equipe funcional para as equipes multidisciplinares;

- concorrência com as atividades da área funcional, quando a transição não é meta para as demais equipes; e

- ideia de que a transição será um processo passageiro e depois de concluída, retornarse-á ao modelo anterior.

Além destes, outros desafios também foram mencionados por mais de um entrevistado. São eles:

- resistência da gestão devido à mudança para uma tomada de decisão descentralizada e medo de perda do poder depois da transição;

- dificuldade na priorização de projetos, focando apenas nos que trazem maior valor para o negócio.

Por fim, ainda foram mencionados outros desafios presentes nas organizações, como a visibilidade dos problemas, a comunicação, a cultura diferenciada e a descrença no modelo ágil. As respostas dos entrevistados podem ser observadas resumidamente no Quadro 39 a seguir.

Quadro 39 - Resumo das respostas dos entrevistados - Desafios da transformação ágil

\begin{tabular}{|c|c|c|c|c|c|c|c|c|c|c|}
\hline Desafio & E1 & E2 & E3 & E4 & $\mathbf{E 5}$ & E6 & E7 & E8 & E9 & E10 \\
\hline Engajamento das equipes & $\checkmark$ & $\checkmark$ & & $\checkmark$ & & $\checkmark$ & & & $\checkmark$ & $\checkmark$ \\
\hline Resistência da gestão & $\checkmark$ & & & & $\checkmark$ & & & & $\checkmark$ & \\
\hline Priorização de projetos & & $\checkmark$ & $\checkmark$ & & & & & & & \\
\hline Visibilidade dos problemas & & & & & $\checkmark$ & & & & & \\
\hline Importância das cerimônias & & & & & & & & $\checkmark$ & & \\
\hline Comunicação & & & & & & & & & $\checkmark$ & \\
\hline Cultura diferenciada & & & & & & & & & $\checkmark$ & \\
\hline Descrença no modelo ágil & & & & & & & & & & $\checkmark$ \\
\hline
\end{tabular}

Fonte: Quadro elaborado pela autora, com base nas entrevistas. 
Em relação à pergunta Q30, as principais recomendações mencionadas pelos entrevistados referem-se a:

- Necessidade de avaliar se o modelo ágil é aderente à cultura da organização, antes de iniciar a transição;

- Definir os objetivos da transição e obter a apoio da gestão;

- Realizar a transição gradativamente, utilizando o conceito de melhoria contínua, tendo como meta final implementar em todo o processo, por cadeia de valor;

- Comunicar os objetivos da transição e envolver as equipes, de todos os níveis hierárquicos, desde o início da transição;

- Criar uma área de Change Management, com a participação do RH, que apoie nos treinamentos, na atribuição dos novos papéis e responsabilidades e na formação das equipes;

- Definir metas compartilhadas para aumentar o engajamento das demais áreas com o novo processo;

- Realizar o acompanhamento das equipes no novo modelo e na divulgação dos resultados.

As respostas dos entrevistados podem ser observadas resumidamente no Quadro 40.

Quadro 40 - Resumo das respostas dos entrevistados - Recomendações às organizações

$\begin{array}{lllllllllll}\text { Recomendações } & \text { E1 } & \text { E2 } & \text { E3 } & \text { E4 } & \text { E5 } & \text { E6 } & \text { E7 } & \text { E8 } & \text { E9 } & \text { E10 }\end{array}$

Avaliar a aderência com a cultura e com a estratégia da organização

Definir os objetivos da transição

Obter o apoio da gestão

Pensar no processo fim a fim, por cadeia de valor

Realizar a transição gradativamente

Comunicar os objetivos da transição para todos os níveis

Envolver as equipes, desde o início

do processo de transição

Criar uma área de Change

Management

Treinar as equipes nas práticas, papéis e responsabilidades

Mesclar a equipe interna com as novas contratações

Definir metas compartilhadas entre as equipes

\begin{tabular}{lll} 
Acompanhar a transição com as & $\checkmark$ & $\checkmark$ \\
equipes & $\checkmark$ & $\checkmark$ \\
Divulgar os resultados da transição & $\checkmark$ & \\
\hline
\end{tabular}

Fonte: Quadro elaborado pela autora, com base nas entrevistas. 
4.4 APLICABILIDADE DAS PRÁTICAS RECOMENDADAS PELA LITERATURA ACADÊMICA

No que tange à aplicabilidade das práticas recomendadas, o objetivo foi verificar se as recomendações propostas pela literatura foram assimiladas pelas organizações analisadas (Quadro 41). 
Quadro 41-Recomendações da literatura acadêmica versus aplicabilidade pelas organizações analisadas

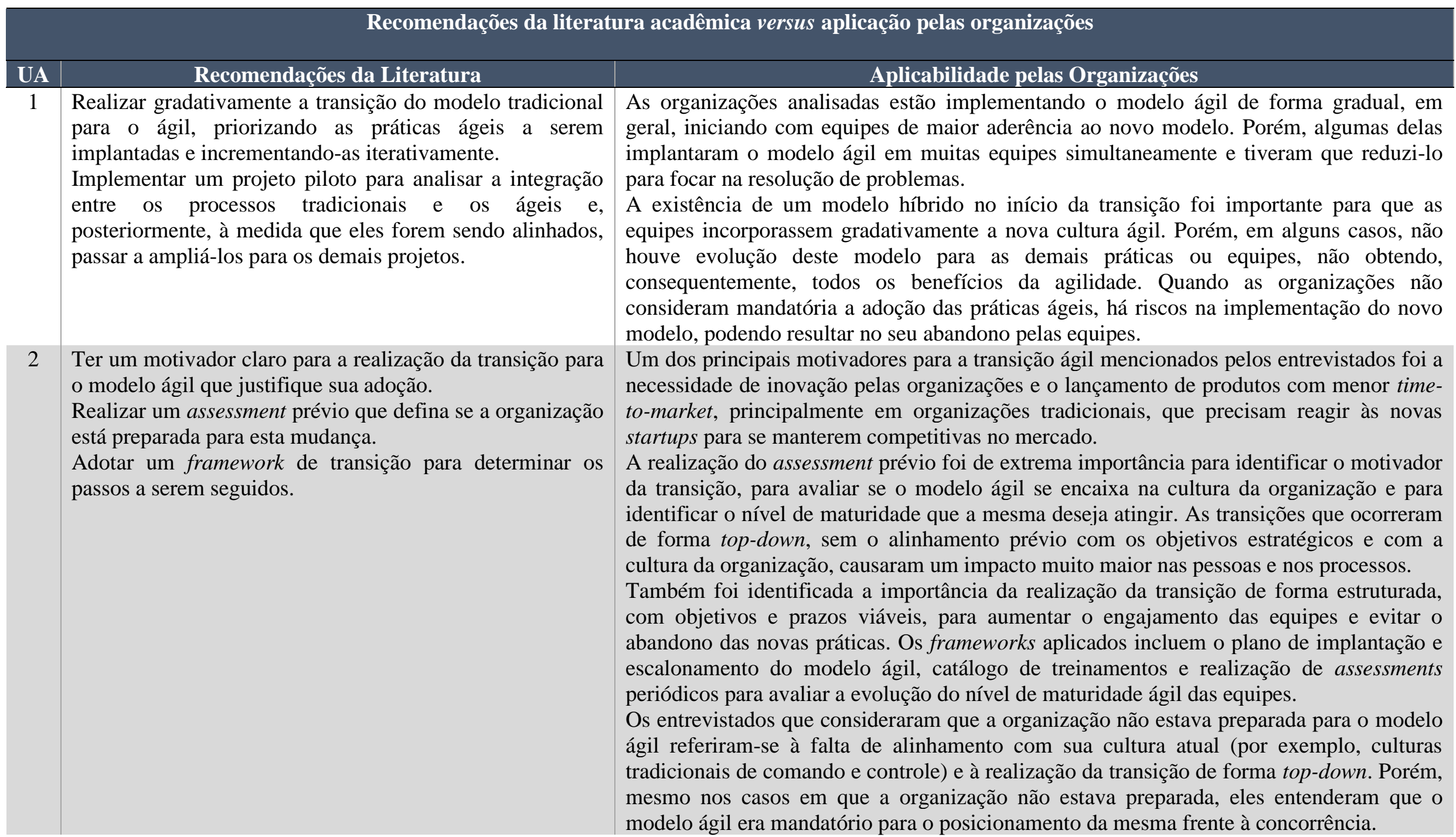


3 A organização deve adotar um processo de melhoria contínua, priorizando algumas práticas e evoluindo à medida que as equipes forem se adaptando às práticas já aplicadas e aos resultados obtidos.

Os resultados do modelo ágil devem ser medidos e comparados com os resultados anteriores no modelo tradicional, para apoiar na evolução do processo.

4 Definir previamente, antes do início do projeto, quais processos serão adotados e alinhar com as distintas áreas da organização qual será entregue.

Implementar um projeto piloto para analisar a integração entre os processos tradicionais e os ágeis e ampliar para os demais projetos à medida que os processos forem sendo alinhados.

\section{(Continuação)}

A transição ágil trouxe muitos benefícios para as organizações, tanto em relação aos processos, incluindo entregas mais rápidas e com maior qualidade, quanto em relação às pessoas, com maior integração e colaboração entre as equipes. Porém, para que a organização conseguisse avaliar o cumprimento dos objetivos, foi necessário que eles tivessem sido definidos claramente antes de iniciar a transição. Também foi necessário haver indicadores e ferramentas para aferir os resultados.

Houve uma grande variação nas métricas utilizadas para definir o sucesso da transição e apenas alguns dos entrevistados relataram que elas foram utilizadas no processo de melhoria contínua, estabelecendo os temas nos quais a organização deveria atuar. Outros relataram que a organização ainda carecia da definição de métricas para que conseguisse avaliar os resultados.

A percepção de alguns dos entrevistados foi de que os objetivos da transição ainda não haviam sido atingidos, principalmente devido à necessidade de implantação nas demais áreas e de mudança para o mindset ágil.

Quanto à inovação, o modelo ágil não necessariamente faz com que as organizações se tornem mais inovadoras. O que realmente impacta na inovação são práticas de experimentação, como as de Inception e Design Thinking, focadas no feedback do cliente.

Alguns dos entrevistados entenderam que nem todos os projetos adaptam-se ao modelo ágil, tais como os projetos com escopo bem definido ou os que a organização já possui know-how. É importante que a organização defina quais tipos de projetos serão realizados de forma ágil e quais serão mantidos no modelo tradicional, conforme a característica de cada produto. Esta definição deve considerar o custo dos projetos, que pode ser mais baixo no modelo tradicional, devido ao custo de manutenção de equipes dedicadas ao modelo ágil. 
5 Prover uma estimativa de custo e de prazo em alto nível, no início do projeto e aprovar o investimento inicial. A cada detalhamento do projeto, revisar as estimativas.

As organizações ainda têm grande dificuldade em aceitar a execução de projetos sem um prazo definido. Apenas dois dentre os dez entrevistados informaram que suas organizações não requerem o prazo de entrega do projeto. Mesmo as organizações que trabalham com estimativas em alto nível, ainda precisam reportar os desvios aos executivos e, em alguns casos, solicitar a aprovação de Change Requests. Porém, alguns dos entrevistados declararam que o prazo definido no modelo tradicional, na maioria das vezes, não é cumprido, portanto há benefício na utilização do modelo ágil.

Outra dificuldade apontada pelos entrevistados foi o lançamento de produtos sem todas as suas funcionalidades, de acordo com o conceito de experimentação.

Apesar de ser um dos pilares do modelo ágil, a priorização de projetos e funcionalidades de acordo com o valor para o negócio ainda é um desafio para as organizações, pois demanda uma mudança de mindset. A mudança constante de priorização e a tomada de decisões de forma top-down são fatores de grande insatisfação e perda de produtividade das equipes por impactarem no prazo de entrega dos projetos.

6 Definir milestones adaptados ao modelo ágil e, com base neles, criar relatórios básicos.

Medir o progresso através do gráfico de burndown.

Os executivos das organizações ainda demandam o recebimento formal do Status Report do projeto. A visibilidade do modelo ágil traz outras opções de Status Report, que demandam mudança de mindset pela organização para acessar as informações disponíveis.

Avaliar o progresso do projeto baseado na entrega do software funcionando.

8 A nova forma de comunicação do modelo ágil requer maior integração e comunicação entre a equipe.

A percepção de alguns dos entrevistados foi de que com o modelo ágil houve melhoria na comunicação interna da equipe e entre as áreas de Tecnologia e Negócios, devido à formação de equipes multidisciplinares. Porém, a comunicação ainda é um desafio para algumas organizações. Mesmo com o modelo ágil, diversos entrevistados mencionaram a dificuldade na comunicação entre as áreas. É importante a criação de um papel de integração para realizar o sincronismo entre as equipes e para minimizar o problema de comunicação.

O modelo ágil também traz maior visibilidade ao que as equipes estão fazendo, porém também aos problemas ocorridos. Por isso, pode haver resistência por parte das equipes quanto a esta transparência, inclusive no nível executivo. 


\section{UA Recomendações da Literatura}

11 Comunicar (top-down) a importância de utilizar o mesmo modelo inter-áreas e os impactos pelo fato de as equipes não estarem em sintonia.

13 Treinar toda a equipe do projeto no modelo ágil, em negócio e em soft skills.

Alocar membros da equipe em um único projeto para manterem o foco e a agilidade.

14 O Gerente de Projetos deve assumir um papel de facilitador da equipe e não mais de liderança, estimulando todos a contribuírem com a tomada de decisão do projeto. A equipe do projeto deve assumir uma posição de protagonismo e ser auto organizável.

\section{Aplicabilidade pelas Organizacões}

A implantação do modelo ágil nas diversas áreas que participam do projeto é fator chave para que todo o processo seja otimizado. Diversas organizações iniciaram a adoção em uma área Digital ou de Tecnologia, porém não a expandiram para as demais, gerando diversas barreiras para o andamento do projeto e não colhendo todos os benefícios do novo modelo.

Há uma redistribuição de papéis no interior das equipes. O PO assume responsabilidades que antes eram atribuídas ao Gerente de Projetos. O SM deve ter um perfil de liderança, além do técnico.

A mudança no perfil da equipe pode resultar também na substituição de funcionários que não se adaptarem ao novo modelo, ou ainda em um turnover natural na organização. Por este motivo, é imprescindível que o processo de transição seja acompanhado pelo RH ou por uma equipe de Change Management e que haja a capacitação dos funcionários nas novas competências comportamentais e no novo perfil multidisciplinar que deverão assumir. Porém, vemos que poucas organizações investiram no treinamento de seus funcionários em soft skills e em negócio.

O papel do GP é bastante reduzido em equipes ágeis, devido à distribuição entre os novos perfis de SM, de $\mathrm{PO}$ e da própria equipe de desenvolvimento. Algumas organizações mantiveram o papel de GP, porém lhe atribuindo menores responsabilidades internas; outras, segregaram os tipos de projetos que requeriam um GP, ou ainda mudaram para outro perfil, como SM, PO ou AE.

A autonomia das equipes ágeis ainda é uma grande dificuldade para as organizações, principalmente em relação ao poder de decisão do PO quanto às funcionalidades do produto. Organizações tradicionais, enraizadas no modelo de comando e controle, ainda dependem da tomada de decisão dos executivos, até mesmo para o nível de definição e priorização de funcionalidades.

As organizações que delegam a tomada de decisão para o nível da equipe, de acordo com a proposta do modelo ágil, percebem um impacto positivo na produtividade e na satisfação dos funcionários. 


\section{UA Recomendações da Literatura}

15 Todos os membros da equipe devem assumir um papel colaborativo e manterem o ownership compartilhado do projeto.

16 A gestão deve comunicar à equipe os objetivos da transição, para ter expectativas claras quanto ao processo e às práticas ágeis.

Também deve haver obrigatoriedade de adotar o novo processo na organização, caso contrário, a equipe não se sentirá motivada para mudar.

17 Manter clientes dedicados ao projeto, com o mesmo papel de colaboração e de comunicação que os demais membros da equipe. Criar um entregável a cada intervalo de tempo fixo, que possa ser validado pelo cliente.

Treinar os clientes nos processos e nos valores do modelo ágil.

\section{A plicabilidade pelas Organizač̃es}

Todos os entrevistados relataram que a colaboração melhorou consideravelmente depois da transformação ágil, principalmente no interior da equipe.

A tomada de decisão descentralizada causa grande impacto no ownership da equipe, pois ela se sente dona do processo e se motiva para entregá-lo.

No início da transição, pode haver um período de adaptação das equipes a esse novo papel de colaboração, pois havia, anteriormente, dependência do Gerente de Projetos ou do Gerente Funcional para resolver os impedimentos. Porém, as equipes que evoluem nesse sentido, sentem-se empoderadas para resolver os problemas, sem necessidade de escalonamento.

A maioria dos entrevistados relatou que houve resistência das equipes, principalmente no início da transição, relacionada à descrença das pessoas quanto ao novo modelo ou ao aumento de responsabilidades e de atividades das equipes.

Como o modelo ágil impacta os processos e as pessoas, houve resistência principalmente por parte dos funcionários mais antigos, que não aceitavam ter que mudar a forma como trabalhavam, pois já estavam acostumados.

A comunicação dos objetivos da transição foi realizada pela maioria das organizações e atuou como redutor de resistência.

A comunicação também foi considerada eficiente na divulgação dos resultados da transição, aumentando o senso de pertencimento e o engajamento das equipes.

A percepção de que, após o término da transição, os processos retornariam ao modelo anterior foi um fator de grande resistência e refletiu na descrença quanto ao novo modelo, ressaltando a necessidade de comunicação, de treinamento e de acompanhamento das equipes pela área responsável pela transição e pelo apoio de Change Management.

A principal dificuldade na dedicação do cliente ou PO nas equipes ágeis deve-se ao aumento de responsabilidades dessas áreas, que devem se dividir entre operação e projetos. Uma das causas é a definição de metas diferenciadas entre as equipes, que não priorize a atuação das demais áreas nos projetos.

(Continua) 
19 Treinar a equipe do projeto no modelo ágil.

Alocar um coach externo à organização para apoiar o processo de transição.

Definir uma equipe de transição para apoiar na aplicação do modelo.
A mudança de mindset na organização refere-se principalmente à aceitação do novo modelo de tomada de decisão descentralizada pelas equipes e pelos executivos das organizações mais hierárquicas e à aplicação dos novos processos de priorização e de experimentação, bastante disruptivos em relação ao modelo tradicional. Em alguns casos, a mudança de mindset ocorreu apenas em algumas áreas da organização, resultando em culturas diferenciadas entre si.

Todos os entrevistados informaram que houve contratação de uma consultoria externa para implementar a transição, variando apenas em relação ao escopo de atuação. A alocação de um Agile Coach para realizar o acompanhamento com as equipes é um fator primordial para gerar engajamento, fortalecer o conhecimento e evitar o abandono das práticas. Outro benefício mencionado por um dos entrevistados foi a contratação da consultoria para realizar tanto a estratégia quanto a operacionalização da transição, podendo ajustar o modelo proposto de acordo com os resultados obtidos.

21 Reduzir o micro management dos níveis gerenciais e delegar a tomada de decisões.

Redefinir as expectativas de controle do projeto, tais como estimativas e relatórios de progresso.

22 Modificar os níveis hierárquicos, reduzindo-os a uma estrutura mais horizontalizada em toda a organização.
A maior parte dos entrevistados informou que houve resistência dos executivos, principalmente no nível da média gestão, devido ao medo de perda do poder; à disponibilização de seus recursos para os projetos; e à visibilidade e questionamento das atividades da sua equipe.

As organizações acostumadas à forte hierarquia e ao modelo de comando e controle são as que apresentam maior resistência por parte dos gestores, pois requerem uma mudança drástica para o modelo ágil de colaboração. Esta descentralização da tomada de decisão pode ser considerada uma ameaça aos gestores que têm medo de perder o poder.

A transformação ágil não está alterando a estrutura das organizações, mantendo, na maioria das vezes, os níveis hierárquicos vigentes, o que pode contribuir para a resistência da gestão à descentralização na tomada de decisão.

$\mathrm{Na}$ maioria das vezes, os cargos foram apenas renomeados para os novos cargos ágeis, sem um treinamento adequado em relação à atribuição dos novos papéis e das novas responsabilidades ou mesmo sem o apoio da equipe de Change Management para acompanhar os impactos destas mudanças. Outra forma não tão nobre percebida nas 


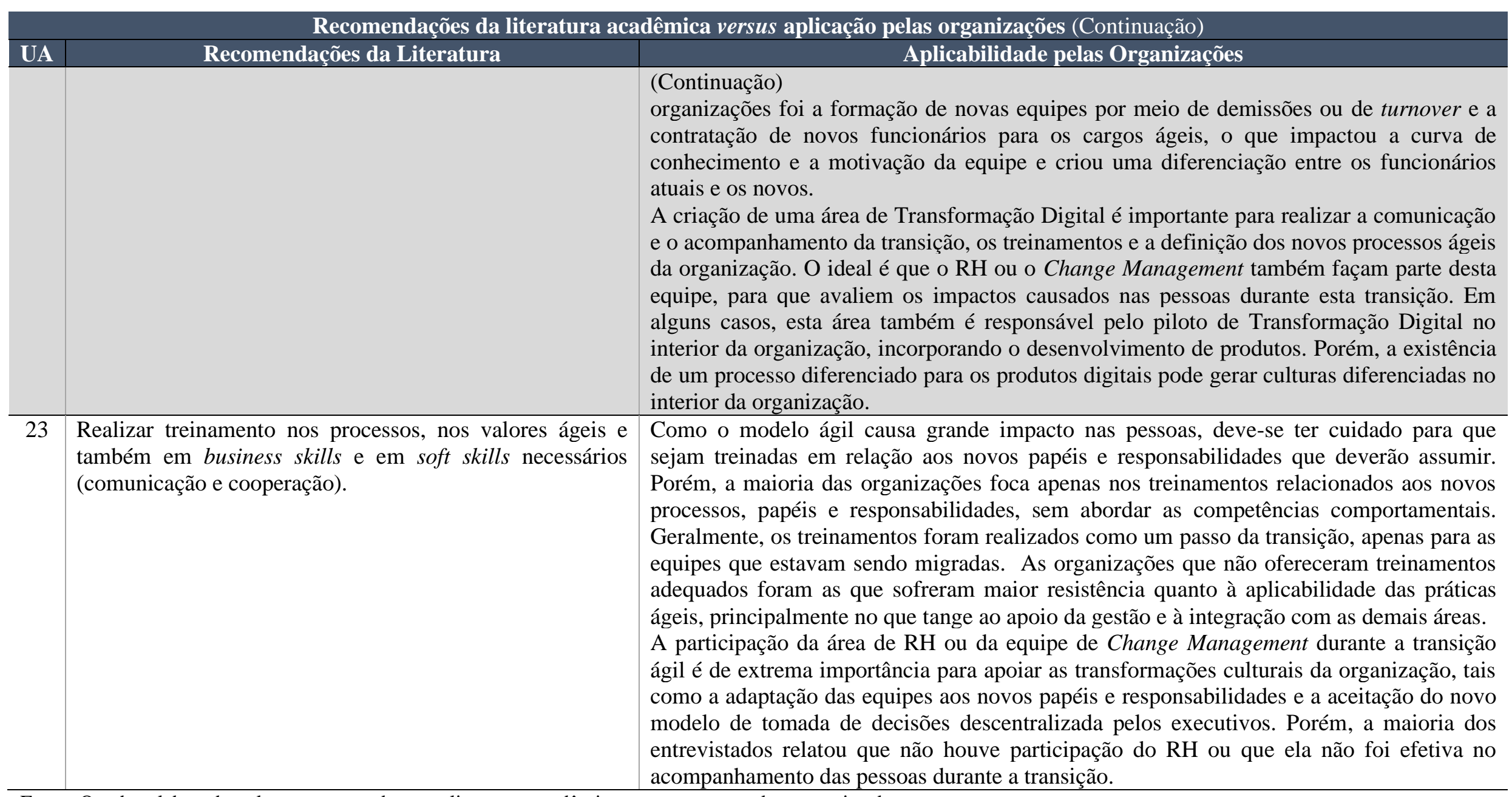

Fonte: Quadro elaborado pela autora, com base na literatura acadêmica e nas respostas dos entrevistados. 


\subsection{PRÁTICAS RECOMENDADAS}

O objetivo da presente pesquisa foi atingido ao elaborar as recomendações quanto às principais práticas que podem facilitar a realização da transição do modelo tradicional para o ágil no que tange à gestão de projetos de desenvolvimento de software. Estas práticas foram baseadas tanto na literatura acadêmica quanto nas respostas dos entrevistados em relação aos principais desafios e recomendações (Quadro 41), bem como na percepção pessoal da autora sobre os demais pontos de atenção identificados durante as entrevistas.

Assim como foi feito na Análise dos Resultados da RSL e da Coleta de Dados Primários, as Práticas Recomendadas também foram subdividas em Processos, Pessoas, Gestão e Organização.

\subsubsection{Processos}

- Avaliar a aderência do modelo ágil com a estratégia da organização (UA 2).

A literatura recomenda que, antes de iniciar a transição, a organização tenha um motivador claro, de modo que a mesma esteja alinhada aos seus objetivos estratégicos, (conforme subitem 4.1.1.2 Preparação para a transição ágil - RSL). As entrevistas permitiram constatar que, para que haja a sustentabilidade do novo modelo, a transição deve ser o objetivo da organização como um todo, e não apenas uma iniciativa de uma área indivual. As transições realizadas apenas em uma área específica, sem o apoio da alta gestão da organização, apresentaram um risco muito maior ao serem executadas (conforme subitem 4.2.1.2 Preparação para a transição ágil - coleta de dados primários).

- Definir os objetivos da transição (UA 2 e UA 3).

A recomendação da literatura é que seja realizado um assessment antes de iniciar a transição para o modelo ágil e outro depois de sua conclusão (conforme subitens 4.1.1.2 Preparação para a transição ágil - RSL e 4.1.1.3 Resultados da transição RSL), a fim de identificar o nível de maturidade ágil inicial e o final da organização. Porém, a pesquisa exploratória identificou a necessidade adicional de definir, no assessment inicial, quais eram os objetivos da transição e o nível de maturidade ágil almejado pela organização para possibilitar o acompanhamento dos resultados no assessment final (conforme subitem 4.2.1.3 Resultados da transição - coleta de dados 
primários). Estes objetivos devem ser alinhados com a alta e a média gestão, tanto no nível estratégico quanto no operacional, para que haja o apoio efetivo de todos os níveis da gestão. Também é importante definir os indicadores e os milestones que serão acompanhados durante o processo para avaliar se a transição está sendo bem sucedida.

- Pensar em todo o processo por cadeia de valor, porém executar a transição gradativamente (UA 1).

A realização da transição de forma gradual e iterativa é recomendação unânime tanto pela literatura (conforme subitem 4.1.1.1 Transição Big Bang - RSL) quanto pela prática nas organizações analisadas (conforme subitem 4.2.1.1 Transição Big Bang coleta de dados primários), pois minimiza a resistência das equipes, escalando o novo modelo somente após a adaptação das equipes atuais. Todos os entrevistados mencionaram que a transição iniciou gradativamente na organização. Porém, constatou-se que a transição para o modelo ágil em apenas uma área específica não agrega valor à organização (conforme subitens 4.2.1.1 Transição Big Bang - coleta de dados primários e 4.2.1.3 Resultados da transição - coleta de dados primários). Portanto, a fim de evitar gargalos no processo, também devem ser envolvidas as demais áreas que fazem parte da cadeia de valor do produto, tais como as de Produtos, Compras, Infraestrutura e outras. Ao realizar a transição, deve-se iniciar com uma área piloto, geralmente com a que apresenta maior aderência ao modelo ágil e, seguindo o conceito de melhoria contínua, ir agregando paulatinamente as demais áreas que participam do processo e conforme ofeedback da equipe.

- Criar um modelo híbrido intermediário (UA 1).

A transição gradual muitas vezes resulta na criação de um modelo híbrido no início da transição, iniciando com algumas práticas e expandindo gradativamente, conforme as equipes forem se adaptando. A literatura reconhece a prática de modelos híbridos de gestão de projetos (conforme subitem 2.1.3 Modelos Híbridos de Gestão de Projetos), porém, constatou-se durante as entrevistas (conforme subitem 4.2.1.1 Transição Big Bang - coleta de dados primários) que a realização dos ritos ágeis deve ser considerada mandatória desde o início da transição, para minimizar o risco de abandono do novo modelo pelas equipes e para evoluir na transição até que sejam atingidos todos os benefícios da agilidade. 
- Adaptar o modelo ágil aos processos da organização (UA 4).

Cada organização atua em um segmento distinto, entrega produtos distintos e possui uma cultura distinta. Portanto, dependendo do tipo de produto ou do projeto, sempre haverá necessidade de adaptar o modelo ágil aos processos atuais da organização, resultando, muitas vezes, em um modelo híbrido ou na manutenção de processos tradicionais e ágeis paralelamente. A literatura afirma que o modelo ágil não é adaptável a todos os tipos de projeto (conforme subitem 4.1.1.4 Processos organizacionais - RSL). Porém, alguns dos entrevistados informaram que as organizações pressionam para que todos os projetos fossem migrados para o modelo ágil (conforme subitem 4.2.1.4 Processos organizacionais - coleta de dados primários). Para superar este desafio, as organizações devem avaliar, no início da transição, quais processos serão migrados para o modelo ágil e quais os que serão mantidos no modelo tradicional, considerando a eficiência e o custo da transição e revisando-os periodicamente, a cada ciclo de maturidade.

- Priorizar os projetos que geram valor para o negócio (UA 5).

A priorização dos projetos de acordo com a geração de valor foi descrita como uma prática mandatória do modelo ágil (conforme subitem 2.1.2 Modelos de Gestão de Projetos Ágeis), pois direciona a execução de atividades realmente importantes para a organização e aumenta a satisfação das equipes, evitando que realizem muitas atividades simultaneamente ou ainda que percam o foco com a troca frequente de atividades. Na pesquisa bibliográfica, a priorização de projetos não foi identificada como um desafio ou uma Unidade de Análise a ser estudada. Porém, no decorrer das entrevistas, foi mencionada como uma das principais dificuldades das organizações depois da transição para o modelo ágil (subitem 4.2.1.5 Estimativas - coleta de dados primários). Esta priorização deve ser considerada um rito periódico na organização (por exemplo, trimestralmente) e deve estar alinhada com os seus objetivos estratégicos.

- Adotar o modelo de experimentação (UA 5).

Um dos principais conceitos do modelo ágil, utilizado principalmente na inovação de produtos, é a criação do MVP (conforme subitem 2.1.2 Modelos de Gestão de Projetos Ágeis). Trata-se de um produto que ainda não possui todas as funcionalidades 
desejadas, mas pode ser lançado no mercado em forma de experimentação. As entrevistas realizadas demonstraram grande resistência por parte das organizações na adoção do modelo de experimentação, devido à necessidade de mudança de mindset no lançamento de "produtos inacabados" ao mercado. Porém, tal modelo foi considerado pelos entrevistados como uma importante prática ágil de inovação de produtos (conforme subitem 4.2.1.5 Estimativas - coleta de dados primários). A aplicação de processos de Discovery, tais como Inception e Design Thinking, que trazem o cliente interno ou externo para a obtenção de feedback, auxiliam na priorização das atividades agregando valor para o negócio (conforme subitem 4..2.1.3 Resultados da transição - coleta de dados primários).

\subsubsection{Pessoas}

- Comunicar os objetivos da transição para todos os níveis hierárquicos (UA 16). Ao iniciar a transição para o modelo ágil, deve-se comunicar claramente a todos da organização quais serão os objetivos e como ocorrerá o processo de transição, garantindo que a informação seja cascateada para todos os níveis hierárquicos, conforme descrito na literatura (conforme subitem 4.1.2.5 Resistência à mudança RSL). É imprescindível que haja a participação das equipes desde o início da transição, para que todos se sintam parte do processo e contribuam com a definição do novo modelo. Esta prática é recomendada pela literatura e corroborada pelos entrevistados (conforme subitem 4.2.2.4 Resistência à mudança - coleta de dados primários). Constatou-se que a decisão da transição de forma top-down, sem a participação de todos os níveis hierárquicos no processo, pode aumentar a resistência à mudança por parte das equipes.

- Contratar uma consultoria especializada em transformação digital (UA 19).

A contratação de consultoria, ou de um Agile Coach, ambos externos à organização, é de extrema importância para apoiar na realização dos assessments; na definição do framework de transição alinhado à realidade da organização; e na realização dos treinamentos. Além da aplicação das novas práticas, a consultoria também é imprescindível para a disseminação do novo mindset ágil, propondo ações de melhoria de forma isenta e reduzindo os conflitos entre as áreas. Esta prática é altamente recomendada pela literatura (conforme subitem 4.1.2.8 Mudança de mindset - RSL) e 
utilizada por todas as organizações analisadas. Constatamos que as organizações que iniciaram a transição sem uma consultoria ou coach externos, só obtiveram tração depois da contratação de um deles, reafirmando a importância de ambos (conforme subitens 4.2.1.1 Transição Big Bang - coleta de dados primários e 4.2.2.6 Mudança de mindset - coleta de dados primários).

- Definir metas compartilhadas entre as equipes (UA 17).

A definição de metas compartilhadas entre as áreas que participam do processo não foi identificada durante a RSL como uma Unidade de Análise a ser estudada, porém, foi mencionada no decorrer das entrevistas (conforme subitem 4.2.2.5 Cliente dedicado coleta de dados primários) como uma importante prática para aumentar o engajamento das equipes durante a transição ágil e para reduzir a concorrência dos projetos com as demais atividades operacionais. Estas metas devem refletir a priorização definida anteriormente, cascateando os objetivos estratégicos para o nível operacional. Os benefícios são a redução da resistência das equipes e a participação das demais áreas no processo, de forma colaborativa.

\subsubsection{Gestão}

- Avaliar a aderência do modelo ágil à cultura da organização (UA 2, UA 19 e UA 21). A literatura sugere tanto a realização de um assessment inicial (conforme subitem 4.1.1.2 Preparação para a transição ágil - RSL) para avaliar se a organização está preparada para a transição, como também a contratação da uma consultoria ou coach externos para auxiliar na mudança de mindset (conforme subitem 4.1.2.8 Mudança de mindset - RSL). Os entrevistados consideraram essa prática importante para que a organização avaliasse se o modelo ágil se encaixava em sua cultura e identificasse se a mesma está preparada para o novo mindset ágil, por exemplo, em relação à gestão descentralizada, à formação de equipes multidisciplinares dedicadas aos projetos e ao processo de experimentação.

$\mathrm{O}$ assessment reduz o risco de implementar uma cultura que não se ajuste às organizações, principalmente às tradicionais e consolidadas, que atuam no modelo de comando e controle. Neste caso, a realização da transição de forma gradual, a definição prévia dos processos que serão migrados para o novo modelo e a participação dos níveis executivos nos treinamentos auxiliam no aculturamento da 
gestão, reduzindo a resistência e obtendo o seu apoio durante a transição. Estas recomendações podem ser observadas principalmente no subitem 4.1.2.1 Preparação para a transição ágil - coleta de dados primários.

\subsubsection{Organização}

- Criar uma área de Transformação Digital na organização (UA 22 e UA 23).

A literatura recomenda a participação da área de Recursos Humanos durante a transição ágil (conforme descrito no subitem 4.1.4.1 Estrutura hierárquica - RSL). Diversos entrevistados também mencionaram a criação de uma área interna de transformação como fator chave na transição ágil (conforme subitem 4.2.4.1 Estrutura hierárquica - coleta de dados primários). Além da consultoria, que trará um olhar externo à organização, o RH será o elo entre esta área e as demais, trazendo os objetivos da transição para a realidade da organização. A área de Recursos Humanos deve ser composta por uma equipe multidisciplinar, incluindo a sua própria equipe. Além da aplicação do novo processo, esta área deve ser responsável também pela implantação de um processo de Change Management, avaliando o impacto da transformação nos papéis e responsabilidades; analisando as mudanças para o perfil de colaboração dos funcionários e gestores; e realizando o acompanhamento das equipes para aumentar o engajamento.

- Treinar as equipes nos processos e competências comportamentais (UA 23).

Conforme descrito na literatura (conforme subitem 4.1.4.2 Treinamento - RSL), os treinamentos, geralmente ministrados pela consultoria contratada e acompanhados pela área interna de Transformação Digital, devem englobar os novos processos ágeis (tais como o Scrum e o Kanban), para se adaptarem à mudança nos papéis e responsabilidades das equipes e às competências comportamentais (soft skills) requeridas para este novo perfil. Nas entrevistas realizadas, foi identificada também a importância da participação de todos os níveis hierárquicos nos treinamentos, para entendimento do processo ágil e redução da resistência em todos os níveis (conforme subitem 4.2.4.2 Treinamento - coleta de dados primários). 
- Acompanhar a transição com as equipes (UA 19 e UA 22).

Mudanças são sempre difíceis de serem implementadas, principalmente as que causam impacto nas pessoas. Por este motivo, alguns dos entrevistados mencionaram a importância do acompanhamento periódico de cada equipe, durante o processo de transição, pela equipe de transformação e pela consultoria contratada, até que os novos processos e valores estejam consolidados (conforme subitens 4.2.2.6 Mudança de mindset - coleta de dados primários e 4.2.4.1 Estrutura hierárquica - coleta de dados primários). Esta ação reduz o abandono das novas práticas e faz com que as equipes entendam que a transição não será passageira, e sim o novo processo que será implantado pela organização.

- Divulgar os resultados da transição (UA 16).

A divulgação dos resultados da transição foi recomendada apenas pelos entrevistados, com a finalidade de engajar as equipes no novo processo e lhes oferecer uma recompensa depois da implantação do novo modelo (conforme subitem 4.2.2.4 Resistência à Mudança - coleta de dados primários). As divulgações devem ocorrer a cada milestone de implantação, por exemplo, a cada equipe treinada ou migrada para o modelo ágil. Nesta fase, é importante que as metas e os indicadores estabelecidos antes do início da transição sejam acompanhados para avaliar se os objetivos iniciais estão sendo atingidos. 


\section{CONSIDERAÇÕES FINAIS}

\subsection{CONCLUSÕES}

A transição para o modelo ágil na gestão de projetos de desenvolvimento de software é mandatória para as organizações que desejam sobreviver no atual cenário de inovação, e é um passo importante para sua Transformação Digital. Mesmo organizações tradicionais, líderes em seu mercado de atuação, tiveram que se transformar para permanecerem competitivas no mercado, frente à nova concorrência das startups. Porém, a transição para o modelo ágil demanda tempo e esforço por parte das organizações e não requer apenas a mudança do processo de gestão de projetos, mas também a mudança da cultura da organização para os valores ágeis de colaboração, gestão descentralizada e formação de equipes multidisciplinares.

Os principais desafios da transição ágil, mencionados pelos entrevistados e alinhados à literatura, referem-se às pessoas, tais como o engajamento das equipes, a resistência da gestão e a adaptação à nova cultura. Um outro grande desafio para as organizações é no âmbito dos processos, sendo mencionada também a dificuldade de priorização de projetos (não mapeada durante a fase de RSL), que impacta a satisfação das pessoas, devido à concorrência de atividades e à falta de foco das equipes no que é realmente importante para a organização. Mesmo com tantos desafios a serem enfrentados, a transição para o modelo ágil foi considerada, por todos os entrevistados, como uma evolução necessária para as organizações analisadas, visto que os benefícios superam os desafios.

As práticas recomendadas neste estudo visaram, portanto, a facilitar o processo de transição para o modelo ágil na gestão de projetos de desenvolvimento de software nas organizações, tomando por base tanto as ações identificadas na literatura, quanto a análise empírica, ou seja, a realidade das organizações, constatada por meio das entrevistas. Os principais objetivos destas recomendações são minimizar os riscos da implantação do novo processo e reduzir a resistência das equipes ao introduzir a cultura ágil na organização, tanto nos níveis operacionais quanto nos executivos. Porém, devem ser consideradas inclusive as particularidades específicas de cada organização, adaptando as práticas recomendadas ao seu contexto.

Para cada uma das quatro categorias da pesquisa realizada (Processos, Pessoas, Gestão e Organização) sumarizou-se a aplicação das práticas recomendadas às organizações e os resultados obtidos pelas entrevistas, os quais apresentam-se a seguir. 


\section{- $\quad$ Processos}

No que tange aos processos, a recomendação da literatura é que as organizações realizem um assessment para identificar se elas estão preparadas para o modelo ágil, e que determinem um motivador estratégico para esta transição. Na prática, constatou-se que as organizações tradicionais analisadas, burocráticas e com estilo de liderança comando e controle, iniciaram a transição sem esta análise prévia, implementando um modelo de gestão de projetos que não se encaixava na cultura da organização. Mesmo nesses casos, os entrevistados consideraram que a transição para o modelo ágil era mandatória para que a organização pudesse acompanhar as pressões do mercado, estando apta à nova concorrência. A recomendação deste estudo é que, antes de iniciar a transição, seja realizado um assessment, para definir o nível de maturidade ágil vigente na organização e qual o que se deseja atingir, considerando-se o seu contexto. Deve ser obtido o apoio da gestão e, posteriormente, todas as equipes devem ser comunicadas, para que não se tornem barreiras para a implantação do novo modelo e estejam motivadas para realizar as mudanças de processos.

Como constatado pelas entrevistas, a realização da transição para o modelo ágil nas organizações ocorreu de forma gradual, conforme recomendado pela literatura, porém, em alguns casos, com um prazo muito curto ou com a transição de muitas equipes simultaneamente, o que tornou a transição muito mais desafiadora. Algumas das organizações analisadas não ampliaram a adoção do modelo ágil para as demais áreas participantes do processo (além da de Tecnologia), não obtendo, assim, todos os benefícios proporcionados pela agilidade. A recomendação dos entrevistados vai além da literatura, com a definição de todo o processo por cadeia de valor, desde o momento da geração da ideia até a implementação do produto e suporte ao cliente. A transformação deve ser ampliada gradativamente, à medida que as equipes forem sendo adaptadas, até que todo o processo seja migrado para o modelo ágil.

Quanto à adoção de modelos híbridos de gestão de projetos, a literatura reconhece que nem todos os projetos adaptam-se ao modelo ágil. Entretanto, constatou-se certa pressão por parte de algumas organizações para que todos os projetos sejam migrados para o modelo ágil, devido à percepção de que eles serão executados mais rapidamente. O conceito de experimentação dos modelos ágeis, bem como o de priorização de projetos conforme a geração de valor e a falta de definição do custo e de prazo no início dos mesmos, também são bastante disruptivos em relação aos modelos tradicionais, e ainda são desafios a serem 
superados por algumas organizações, requerendo mudança de mindset, principalmente por parte da gestão. Sendo assim, a recomendação é que organização avalie periodicamente qual tipologia de projeto funciona melhor em cada um dos modelos, em função de suas características próprias, e que vá evoluindo gradativamente até atingir o nível de maturidade desejado.

\section{- $\quad$ Pessoas}

A transição para o modelo ágil causa grande impacto nas pessoas, devido à redistribuição de papéis e de responsabilidades e à necessidade de adequação do perfil dos funcionários. As entrevistas possibilitaram a constatação de que nem sempre as organizações se preocuparam com as pessoas durante a transição. Houve relatos de integrantes de equipes afirmando que tiveram que assumir novos papéis sem terem recebido o treinamento adequado para isso. Além do mais, em alguns casos, declararam ter ocorrido a contratação externa de todas as equipes, mantendo culturas diferenciadas entre as ágeis e as não ágeis, ou ainda, houve casos de substituição em massa de todas as pessoas que não se adaptaram ao novo perfil. A maioria dos entrevistados relatou que houve resistência por parte das equipes, principalmente no início da transição. Em alguns casos, foi mencionado que à medida que os resultados iniciais foram sendo apresentados, a resistência foi sendo reduzida e as demais equipes ainda não migradas também quiseram fazer parte do novo modelo.

Os treinamentos são imprescindíveis para o sucesso da transição e recomendados tanto pela literatura quanto pelos entrevistados. Eles devem ser disponibilizados a todos que participam dos projetos, independentemente de áreas ou níveis hierárquicos, focando tanto nos novos processos quanto nas competências comportamentais necessárias para que as equipes possam assumir os novos papéis e responsabilidades. Entretanto, constatamos que a maioria das organizações analisadas realizou apenas treinamentos nos novos processos, sem a preparação das pessoas para as competências do novo perfil.

A autonomia das equipes ágeis também é considerada um grande desafio, principalmente para as organizações tradicionais, enraizadas no estilo de liderança comando e controle e que dependem da tomada de decisão dos executivos. Em contrapartida, a colaboração é um dos principais benefícios do modelo ágil, tendo sido mencionada pelos entrevistados, sobretudo no que tange ao ownership da equipe, uma vez que esta se sente dona do processo e se automotiva a cumprir as entregas e a resolver os problemas sem necessidade de escalonamento. 
A comunicação quanto ao processo de transição também é essencial para reduzir a resistência das equipes ao novo modelo. A literatura recomenda que, antes de iniciar a transição, a organização comunique a todos os funcionários quais são os objetivos da transformação e qual será o impacto nos processos e nas pessoas, garantindo, assim, o cascateamento das informações para todos os níveis hierárquicos. As entrevistas permitiram a constatação de que as organizações que não realizaram a comunicação claramente quanto à transição, ou as que os executivos tomaram decisões de forma top-down, apresentaram maior resistência por parte das equipes, pois elas não se sentiram parte do novo processo. Entretanto, a literatura recomenda que a adoção do novo modelo seja mandatória na organização e que haja o apoio da alta gestão na divulgação, para aumentar o engajamento das equipes. Este ponto foi corroborado pelos entrevistados, que relataram casos de abandono dos ritos ágeis quando a transição não era mandatória, acreditando que seria apenas um processo passageiro.

Outro desafio citado na literatura e confirmado pelos entrevistados é a dedicação do cliente aos projetos, devido à concorrência com as demais atividades operacionais. Para superar este desafio, a recomendação dos entrevistados foi que fossem definidas metas compartilhadas entre as equipes, para que todas as áreas pudessem contribuir de forma efetiva, alinhadas aos objetivos de negócio e à priorização dos projetos definida no nível organizacional.

Por fim, a recomendação de contratação de uma consultoria ou um Agile Coach externos à organização também foi unânime entre a literatura e os entrevistados, com o objetivo de apoiar a execução da transição e auxiliar, de forma isenta, na disseminação do novo mindset ágil. Constatou-se que algumas organizações só conseguiram executar efetivamente o processo de transição depois da contratação da consultoria, e que as iniciativas de realizar a transição apenas em algumas áreas específicas não foi suficiente para realizar a transformação em toda a organização.

\section{- $\quad$ Gestão}

A maioria dos entrevistados mencionou que houve resistência da gestão da organização, devido ao medo de perda de poder dos executivos, à disponibilização de seus recursos para os projetos e à visibilidade das atividades da sua equipe. As organizações hierárquicas que operam no modelo de comando e controle foram as que apresentaram maior resistência por parte dos gestores, pois requeriam uma mudança drástica para o modelo ágil de colaboração. As decisões top-down ainda costumam ocorrer nas organizações, com a 
definição dos novos processos sem a participação das equipes que irão operacionalizá-los, com mudanças frequentes de priorização ou ainda com as solicitações de atividades urgentes, que nem mesmo estão dentre as prioridades definidas previamente. Estas ações acabam desgastando também as equipes, que perdem o direcionamento quanto ao processo a ser seguido.

Quanto a este desafio, a literatura recomenda a realização do assessment para obtenção do apoio dos executivos, antes de iniciar a transição, e a contratação de consultoria externa, para auxiliar na incorporação do novo mindset ágil de forma isenta. Os entrevistados reforçaram também a necessidade da participação dos executivos de todos os níveis nos treinamentos no modelo ágil, para que eles conheçam os benefícios e os novos papéis que deverão assumir.

\section{- $\quad$ Organização}

Apesar de a literatura recomendar que, durante a transição, haja o acompanhamento das pessoas pela área de Recursos Humanos da organização, a maioria dos entrevistados relatou que isso não ocorreu ou que, nos casos em que ocorreu, não foi efetivo. As entrevistas identificaram a necessidade adicional de criação de uma área responsável pela transformação, que inclui o RH ou a equipe de Change Management.

Esta área deve planejar a execução da transição; realizar todas as comunicações; analisar os impactos do novo modelo na cultura da organização; conduzir os treinamentos; acompanhar as equipes durante o processo de transição; e divulgar os resultados obtidos. $\mathrm{O}$ acompanhamento é de extrema importância para a adaptação das pessoas aos novos papéis e responsabilidades, sanando dúvidas em relação ao novo processo e evitando o abandono das práticas ágeis. Da mesma forma, a divulgação dos resultados também colabora com a disseminação da cultura ágil e com a motivação das equipes, para que se sintam parte do novo processo. Além disso, a área de transformação deve cuidar também das contratações e das demissões dos funcionários da organização, de acordo com a necessidade do novo perfil multidisciplinar, procurando mesclar funcionários atuais, que conhecem o negócio, com os novos, que trazem novas ideias à organização. 


\subsection{CONTRIBUIÇÕES E LIMITAÇÕES}

Os resultados apresentados nesta pesquisa foram baseados na literatura disponível sobre o processo de transição ágil e nas informações de dez entrevistados, funcionários de oito organizações nacionais e multinacionais de diversos segmentos, tais como Financeiro (banco, adquirência e mercado de capitais), Tecnologia da Informação, Telecomunicações e Varejo. Os entrevistados foram selecionados de acordo com o networking da autora, e, portanto, não houve restrição por nacionalidade, tamanho, idade ou segmento da organização, sendo o único critério que trabalhassem em organizações que já tivessem passado ou estivessem passando pelo processo de transição ágil.

Não foi solicitado nenhum tipo de comprovação dos resultados obtidos pelas organizações depois da transição para o modelo ágil, tais como o comparativo dos prazos de entrega ou da quantidade de projetos após a mudança para o novo modelo. Portanto, o resultado das entrevistas reflete unicamente a percepção dos entrevistados, visto que o processo de transição leva em consideração critérios subjetivos, tais como comunicação e resistência das equipes, e, assim, podem variar até mesmo entre os entrevistados de uma mesma organização.

Cabe ressaltar, inclusive, que se trata de uma amostra limitada, face ao universo de organizações que estão passando pelo processo de transição ágil, o que não minimiza a importância da presente pesquisa, que possui relevância por ter sido realizada com a aplicação de metodologia consistente para a coleta, tratamento, análise e interpretação dos dados, de modo que os resultados obtidos podem ser considerados fidedignos.

Os resultados obtidos podem ser replicados para um universo mais amplo da realidade de outras organizações nacionais ou multinacionais, seja do segmento de Tecnologia da Informação ou outros e podem ser utilizados para inferir características do setor como um todo, bem como para fornecer diretrizes para eventuais pesquisas futuras, qualitativas ou quantitativas, dado que uma análise ampliada pode vir a trazer informações adicionais às obtidas com a pequena amostra utilizada.

Desta maneira, dando continuidade à presente pesquisa, propõe-se que, em eventual trabalho futuro, seja ampliada a amostra, envolvendo, então, um número maior de organizações, clusterizadas por tamanho, tempo de existência, segmento ou tipologia de produto. Uma análise mais aprofundada permitirá avaliar se há diferenciação da transição para o modelo ágil em função das características específicas de cada cluster. Outra abordagem possível pode ser a realização de entrevistas com mais de um funcionário de uma mesma 
organização, abrangendo níveis hierárquicos diferenciados, buscando identificar os impactos em cada um dos perfis.

Por fim, o escopo da pesquisa também pode ser ampliado, avaliando-se a adoção do modelo ágil escalado, como um passo posterior à transição para o modelo ágil pelas organizações. Estas práticas são focadas no desenvolvimento de produtos e serviços inovadores e consideram toda a cadeia de valor, desde a definição das necessidades do cliente, com práticas de Lean Inception e Design Thinking, até o planejamento e desenvolvimento dos projetos no modelo ágil, objeto deste estudo, e a implementação de OKR's para a definição de metas organizacionais integradas aos processos. 


\section{REFERÊNCIAS BIBLIOGRÁFICAS}

ALMEIDA, Martinho I. R.; FRANCESCONI, M.; FERNANDES, Priscila P. Manual para desenvolvimento de pesquisa profissional. São Paulo: Atlas, 2019.

BECK, K.; BEEDLE, M.; BENNEKUM, A.; COCKBURN, A.; CUNNINGHAM, W.; FOWLER, M.; GRENNING, J.; HIGHSMITH, J.; HUNT, A.; JEFFRIES, R.; KERN, J.; MARICK, B.; MARTIN, R. C.; MELLOR, S.; SCHWABER, K.; SUTHERLAND, J.; THOMAS, D. Manifesto for Agile Software Development, 2001. Disponível em: < http://agilemanifesto.org/>. Acesso em: 29 out. 2018.BOEHM, Barry. Get Ready for Agle Methods, with Care. International Journal of Engineering Science \& Technology, 2002, 4(1), pp. 23-29. Disponível em: <http://sunset.usc.edu/events/2002/arr/Get Ready for Agiel Methods, with Care.pdf>. Acesso em: 18 ago. 2018.

BOEHM, Barry; TURNER, R. Observations on balancing discipline and agility. In: Proceedings of the Agile Development Conference, ADC 2003, pp. 32-39. Disponível em: <https://doi.org/10.1109/ADC.2003.1231450>. Acesso em: 05 out. 2018.

BOEHM, B.; TURNER, R. Management challenges to implementing agile processes in traditional development organizations, 2005. In: IEEE Software, vol. 22, no 5, pp. 3039, Set.-Out. 2005. DOI: 10.1109/MS.2005.129. Disponível em: <https://ieeexplore.ieee.org/document/1504661>. Acesso em: 05 out. 2018.

CAMPANELLI, A. S.; PARREIRAS, F. S. Agile methods tailoring - A systematic literature review. Journal of Systems and Software, 2015, 110, pp. 85-100. Disponível em: <https://doi.org/10.1016/j.jss.2015.08.035>. Acesso em: 30 jan. 2019.

CAMPANELLI, A. S.; CAMILO, R. D.; PARREIRAS, F. S. The impact of tailoring criteria on agile practices adoption: A survey with novice agile practitioners in Brazil. Journal of Systems and Software, 2018, 137, pp. 366-379. Disponível em: <https://doi.org/10.1016/j.jss.2017.12.012>. Acesso em: 16 set. 2018.

CAO, Lan; MOHAN, K.; XU, Peng; RAMESH, Balasubramanian. A framework for adapting agile development methodologies, 2009 Disponível em: <https://doi.org/10.1057/ejis.2009.26>. Acesso em: 07 out. 2018.

CENTRAL COMPUTER AND TELECOMMUNICATIONS AGENCY - CCTA. PRINCE2, n.d. Disponível em: 〈www.prince2.com>. Acesso em: 01 jun. 2018.

CHAN, F. K. Y.; THONG, J. Y. L. Acceptance of agile methodologies: A critical review and conceptual framework. Decision Support Systems, 2009, 46(4), pp. 803-814. 
Disponível em: <https://doi.org/10.1016/j.dss.2008.11.009>. Acesso em: 19 nov. 2018. CHEN, Ronxin; RAVICHANDAR, R.; PROCTOR, D. Managing the transition to the new agile business and product development model: Lessons from Cisco Systems. Business Horizons, 2016, 59(6), pp. 635-644. Disponível em: <https://doi.org/10.1016/j.bushor.2016.06.005>. Acesso em: 31 ago. 2018.

CHINIFOROOSHAN ESFAHANI, Hesan. Transitioning to Agile: A Framework for PreAdoption Analysis using Empirical Knowledge and Strategic Modeling. 2012. 176 f. Tese (Doutorado em Filosofia) - Graduate Department of Computer Science University of Toronto, 2012.

COCKBURN, Alistair; HIGHSMITH, Jim. Agile software development: the people factor. Software Management, 2001, pp. 131-133. Disponível em: <https://doi.org/doi: 10.1109/2.963450>. Acesso em: 06 jan. 2019.

COHN, M.; FORD, D. Introducing an agile process to an organization. Computer, 36(6), 2003, pp. 74-78. Dispnível em: <https://doi.org/10.1109/MC.2003.1204378>. Acesso em: 05 out. 2018.

CONBOY, K.; COYLE, S.; XIAOFENG WANG, L.; PIKKARAINEN, M. People over Process: Key Challenges in Agile Development. Ieee Software, 2011, pp. 48-57. Disponível em: <https://doi.org/10.1109/MS.2010.132〉. Acesso em: 05 out. 2018.

CONBOY, K.; FITZGERALD, Brian. Method and developer characteristics for effective agile method tailoring. ACM Transactions on Software Engineering and Methodology, 2010, 20(1), 1-30. Disponível em: <https://doi.org/10.1145/1767751.1767753>. Acesso em: 31 ago. 2018.

DIKERT, Kim; PAASIVAARA, Maria; LASSENIUS, Casper. Challenges and success factors for large-scale agile transformations: A systematic literature review. Journal of Systems and Software, 2016, 119, pp. 87-108. Disponível em: <https://doi.org/10.1016/j.jss.2016.06.013>. Acesso em: 01 out. 2018.

DINGS $\emptyset$ YR, T.; NERUR, S.; BALIJEPALLY, V.; MOE, N. B. A decade of agile methodologies: Towards explaining agile software development. Journal of Systems and Software, 2012, 85(6), pp. 1213-1221. Disponível em: <https://doi.org/10.1016/j.jss.2012.02.033>. Acesso em: 02 set. 2018.

ESPINOSA-CURIEL, Ismael Edrein; RODRÍGUEZ-JACOBO, Josefina; VÁZQUEZALFARO, Erika; FERNÁNDEZ-ZEPEDA, José Alberto; FAJARDO-DELGADO, Daniel. Analysis of the changes in communication and social interactions during the transformation of a traditional team into an agile team. Journal of Software: Evolution 
and Process, 2018, 30(9), pp. 1-24. Disponível em: <https://doi.org/10.1002/smr.1946>. Acesso em: 02 set. 2018.

FITZGERALD, Brian; HARTNETT, Gerard; CONBOY, Kieran. Customising agile methods to software practices at Intel Shannon. European Journal of Information Systems, 2017, 15(2), pp. 200-213. Disponível em: <https://doi.org/10.1057/palgrave.ejis.3000605>. Acesso em: 02 jan. 2019.

GANDOMANI, Taghi Javdani; ZULZALIL, Hazura; GHANI, Abdul Azim Abdul; SULTAN, Abu Bakar Md; NAFCHI, Mina Ziaei. Obstacles in moving to agile software development methods; at a glance. Journal of Computer Science, 2013, 9(5), pp. 620625. Disponível em: <https://doi.org/10.3844/jcssp.2013.620.625>. Acesso em: 20 nov. 2018.

GANDOMANI, Taghi Jadvani; ZULZALIL, Hazura; GHANI, Abdul Azim Abdul; SULTAN, Abu Bakar Md. Towards comprehensive and disciplined change management strategy in agile transformation process. Research Journal of Applied Sciences, Engineering and Technology, 2012, 6(13), pp. 2345-2351. Disponível em: <https://doi.org/10.19026/rjaset.6.3706>. Acesso em: 18 jan. 2018.

GANDOMANI, Taghi Jadvani: ZULZALIL, Hazura; GHANI, Abdul Azim Abdul; SULTAN, Abu Bakar Md.; SHARIF, Khaironi Yatim. How Human Aspects Impress Agile Software Development Transition and Adoption. International Journal of Software Engineering and Its Applications, 2014, 8(1), pp. 129-148. Disponível em: <https://doi.org/10.14257/ijseia.2014.8.1.12>. Acesso em: 06 jan. 2019.

GANDOMANI, Taghi Jadvani; NAFCHI, Mina Ziaei. An empirically-developed framework for Agile transition and adoption: A Grounded Theory approach. Journal of Systems and Software, 2015, 107, pp. 204-219. Disponível em: <https://doi.org/10.1016/j.jss.2015.06.006>. Acesso em: 18 ago. 2018.

GANDOMANI, Taghi Jadvani; NAFCHI, Mina Ziaei Agile transition and adoption humanrelated challenges and issues: A Grounded Theory approach. Computers in Human Behavior, 2016. Disponível em: <https://doi.org/10.1016/j.chb.2016.04.009>. Acesso em: 19 ago. 2018.

GOOGLE ACADÊMICO (n.d.). Disponível em: 〈scholar.google.com.brr>. Acesso em: 01 set. 2018.

GREGORY, Peggy; BARROCA, Leonor; SHARP, Helen; DESHPANDE, Advait; TAYLOR, Katie. The challenges that challenge: Engaging with agile practitioners' concerns. Information and Software Technology, 2016, 77, pp. 92-104. Disponível em: 
<https://doi.org/10.1016/j.infsof.2016.03.003>. Acesso em: 18 jan. 2019.JOVANOVIĆ, Miloš; MAS, Antonia; MESQUIDA, Antoni-Lluís; LALIĆ, Bojan. Transition of organizational roles in Agile transformation process: A grounded theory approach. Journal of Systems and Software, 2017, 133, pp. 174-194. Disponível em: <https://doi.org/10.1016/j.jss.2017.07.008>. Acesso em: 18 jan. 2019.

KALUS, G.; KUHRMANN, M. Criteria for software process tailoring: a systematic review. Proceedings of the 2013 International Conference on Software and System Process ICSSP 2013, 2013, 171. Disponível em: <https://doi.org/10.1145/2486046.2486078>. Acesso em: 01 fev. 2019.

KITCHENHAM, B. Procedures for Performing Systematic Reviews. Keele University Technical Report TR/SE-0401, 2004. Disponível em: <https://doi.org/10.1.1.122.3308>. Acesso em: 18 jan. 2019.

LEE, MinHwa; YUN, JinHyo Joseph; PYKA, Andreas; WON, DongKyu; KODAMA, Fumio; SCHIUMA, Giovanni; PARK, HangSik; JEON, Jeonghwan; PARK, KyungBae; JUNG, KwangHo; YAN, Min-Ren; LEE, SamYoul; ZHAO, Xiaofei. How to Respond to the Fourth Industrial Revolution, or the Second Information Technology Revolution? Dynamic New Combinations between Technology, Market, and Society through Open Innovation. Journal of Open Innovation: Technology, Market, and Complexity, 2018, 4(3). Disponível em: 〈https://doi.org/10.3390/joitmc4030021〉. Acesso em: 01 fev. 2019.

LINDVALL, Mikael; MUTHIG, Dirk; DAGNINO, Aldo; WALLIN, Christina; STUPPERICH, Michael; KIEFER, David; MAY, John: KÄHKÖNEN, Tuomo. Agile Software Development in Large Organizations, 2004. Disponível em: <https://doi.org/10.1109/MC.2004.231>. Acesso em: 10 fev. 2019.

MAHANTI, Aniket. Challenges in Enterprise Adoption of Agile Methods - A Survey. Journal of Computing \& Information Technology, 2006, 14(3), pp. 197-206. Disponível em: <https://doi.org/10.2498>. Acesso em: 18 fev. 2019.

MEGGINSON, Leon C., Lessons from Europe for American Business, Southwestern Social Science Quarterly, 1963, 44(1), 3-13. Disponível em: $<$ https://citacoes.in/citacoes/584651-charles-darwin-nao-e-o-mais-forte-que-sobrevivenem-o-mais-intel/>. Acesso em: fev. 2019.

NERUR, S.; MAHAPATRA, R.; MANGALARAJ, G. Challenges of migrating to agile methodologies. Communications of the ACM, 2005, 48(5), pp. 72-78. Disponível em: <https://doi.org/10.1145/1060710.1060712>. Acesso em: 03 jan. 2019. 
PIKKARAINEN, Minna; SALO, Outi; KUUSELA, Raija; ABRAHAMSSON, Pekka. Strengths and barriers behind the successful agile deployment-insights from the three software intensive companies in Finland. Empirical Software Engineering, 2012, 17(6), pp. 675-702. Disponível em: <https://doi.org/10.1007/s10664-011-9185-5>. Acesso em: 18 jan. 2019.

POTH, Alexander; SASABE, Susumu; MAS, Antónia; MESQUIDA, Antoni-Lluís. Lean and agile software process improvement in traditional and agile environments. Journal of Software: Evolution and Process, 2018, (Julho), e1986. Disponível em: <https://doi.org/10.1002/smr.1986>. Acesso em: 15 jan. 2019.

PROJECT MANAGEMENT INSTITUTE - PMI. A Guide to the project management body of knowledge - PMBOK, n.d. Disponível em: 〈www.pmi.org>. Acesso em: 01 jun. 2018.

QUMER, A.; HENDERSON-SELLERS, B. A framework to support the evaluation, adoption and improvement of agile methods in practice. Journal of Systems and Software, 2008, 81(11), pp. 1899-1919. Disponível em: <https://doi.org/10.1016/J.JSS.2007.12.806>. Acesso em: 07 out. 2018.

RABECHINI JUNIOR, Roque; CARVALHO, Marly Monteiro de. Gestão de projetos inovadores em uma perspectiva contingencial: análise teórico-conceitual e proposição de um modelo. RAI - Revista de Administração e Inovação. São Paulo, v. 6, n. 3, p. 63 78, set./dez. 2009 .

RIES, E. The Lean Startup. São Paulo: Casa da Palavra LeYa, 2011.

SCHWAB, Klaus. The Fourth Industrial Revolution. What It means and how to respond. Foreign Affairs, 12 dez. 2015, n.p. Disponível em: $<$ https://www.foreignaffairs.com/articles/2015-12-12/fourth-industrialrevolution>. Acesso em: 01 fev. 2019.

SCHWABER, K.; SUTHERLAND, J. Scrum Guide, 2017, 19(6), p. 504. Disponível em: <https://www.scrumguides.org/docs/scrumguide/v2017/2017-Scrum-Guide-US.pdf>. Acesso em: 01 jun. 2018.

SCOPUS. [S.1.], n.d. Disponível em:〈www.scopus.com>. Acesso em: 01 ago. 2018.

SIDKY, A.; ARTHUR, J.; BOHNER, S. A disciplined approach to adopting agile practices: The agile adoption framework. Innovations in Systems and Software Engineering, 2007, 3(3), pp. 203-216. Disponível em: <https://doi.org/10.1007/s11334-007-0026-z>. Acesso em: 06 out. 2018.TOLFO, Cristiano; WAZLAWICK, Raul Sidney; FERREIRA, Marcelo Gomes; FORCELLINI, F. Agile methods and organizational culture: reflections 
about cultural levels. Journal of Software Maintenance and Evolution: Research and Practice, 2009, (23), pp. 423-441. Disponível em: 〈https://doi.org/0.1002/smr.483>. Acesso em: 06 jan. 2019.

WAARDENBURG, G. Van; VLIET, H. Van. When agile meets the enterprise. Information and Software Technology, 2013, 55(12), pp. 2154-2171. Disponível em: <https://doi.org/10.1016/j.infsof.2013.07.012>. Acesso em: 03 fev. 2019. 
APÊNDICES

APÊNDICE A - EXTRAÇÃO DOS DADOS SECUNDÁRIOS

\begin{tabular}{|c|c|c|c|c|}
\hline AUTOR & TÍTULO & DATA & RESUMO & $\begin{array}{l}\text { PALAVRAS- } \\
\text { CHAVE }\end{array}$ \\
\hline $\begin{array}{l}\text { Alistair Cockburn } \\
\text { Jim Highsmith }\end{array}$ & $\begin{array}{l}\text { Agile software development: the } \\
\text { people factor }\end{array}$ & 2001 & $\begin{array}{l}\text { Descrevem os desafios relacionados às pessoas, } \\
\text { encontrados na implantação do modelo ágil, focando } \\
\text { nas habilidades individuais e da equipe. }\end{array}$ & $\begin{array}{l}\text { Agile adoption } \\
\text { challenge }\end{array}$ \\
\hline Aniket Mahanti & $\begin{array}{l}\text { Challenges in Enterprise } \\
\text { Adoption of Agile Methods - A } \\
\text { Survey }\end{array}$ & 2006 & $\begin{array}{l}\text { Demonstra que os modelos ágeis não são indicados para } \\
\text { todos os contextos. Na maioria das organizações, é } \\
\text { indicado um modelo que combine práticas tradicionais } \\
\text { com as ágeis. O artigo demonstra como realizar uma } \\
\text { transição de sucesso para o modelo ágil. }\end{array}$ & $\begin{array}{l}\text { Agile adoption } \\
\text { challenge }\end{array}$ \\
\hline $\begin{array}{l}\text { Asif Qumer } \\
\text { Brian Henderson-Sellers }\end{array}$ & $\begin{array}{l}\text { A framework to support the } \\
\text { evaluation, adoption and } \\
\text { improvement of agile methods in } \\
\text { practice }\end{array}$ & 2008 & $\begin{array}{l}\text { Propõem um framework - Agile Software Solution } \\
\text { Framework (ASSF) para a transição ágil, utilizando o } \\
\text { Agile toolkit para o alinhamento técnico e estratégico. } \\
\text { Apresentam dois estudos de caso de transição, } \\
\text { utilizando o Agile Adoption and Improvement Model } \\
\text { (AAIM). }\end{array}$ & $\begin{array}{l}\text { Agile Transition } \\
\text { Framework }\end{array}$ \\
\hline $\begin{array}{l}\text { Brian Fitzgerald } \\
\text { Gerard Hartnett } \\
\text { Kieran Conboy }\end{array}$ & $\begin{array}{l}\text { Customising agile methods to } \\
\text { software practices at Intel } \\
\text { Shannon }\end{array}$ & 2017 & $\begin{array}{l}\text { Demonstram que modelos ágeis podem ser incompletos } \\
\text { se aplicados individualmente. Propõem, inclusive, uma } \\
\text { combinação da adoção de Scrum e de XP, como } \\
\text { modelos complementares: XP dando o suporte técnico e } \\
\text { Scrum dando o suporte do processo de planejamento e } \\
\text { monitoramento do projeto. }\end{array}$ & $\begin{array}{l}\text { Agile process } \\
\quad \text { tailoring }\end{array}$ \\
\hline $\begin{array}{l}\text { Ismael Edrein Espinosa-Curiel } \\
\text { Josefina Rodríguez-Jacobo } \\
\text { Erika Vázquez-Alfaro } \\
\text { José Alberto Fernández-Zepeda } \\
\text { Daniel Fajardo-Delgado }\end{array}$ & $\begin{array}{l}\text { Analysis of the changes in } \\
\text { communication and social } \\
\text { interactions during the } \\
\text { transformation of a traditional } \\
\text { team into an agile team }\end{array}$ & 2017 & $\begin{array}{l}\text { Afirmam que o processo de transformação ágil influi na } \\
\text { comunicação formal, informal, oral e escrita durante o } \\
\text { projeto. Neste artigo, os autores detalham } 5 \text { desafios } \\
\text { sociais encontrados na transição de uma equipe de } \\
\text { tradicional para ágil. }\end{array}$ & $\begin{array}{l}\text { Agile } \\
\text { transformation } \\
\text { process }\end{array}$ \\
\hline
\end{tabular}


(Continuação)

\begin{tabular}{|c|c|c|c|c|}
\hline AUTOR & TÍTULO & DATA & RESUMO & $\begin{array}{c}\text { PALA VRAS- } \\
\text { CHA VE }\end{array}$ \\
\hline $\begin{array}{l}\text { Kieran Conboy } \\
\text { Sharon Coyle }\end{array}$ & $\begin{array}{l}\text { People over Process: Key } \\
\text { Challenges in Agile Development }\end{array}$ & 2011 & $\begin{array}{l}\text { Apresentam um estudo de caso referente a } 17 \\
\text { organizações que utilizam o modelo ágil, revelando } \\
\text { desafios humanos que incluem recrutamento, } \\
\text { treinamento, motivação e avaliação de performance. }\end{array}$ & $\begin{array}{l}\text { Agile adoption } \\
\text { challenge }\end{array}$ \\
\hline $\begin{array}{l}\text { Kim Dikert } \\
\text { Maria Paasivaara } \\
\text { Casper Lassenius }\end{array}$ & $\begin{array}{l}\text { Challenges and success factors } \\
\text { for large-scale agile } \\
\text { transformations: A systematic } \\
\text { literature review }\end{array}$ & 2016 & $\begin{array}{l}\text { Descrevem os desafios e fatores de sucesso da } \\
\text { implantação do modelo ágil em equipes grandes: } 35 \\
\text { desafios agrupados em } 9 \text { categorias e } 29 \text { fatores de } \\
\text { sucesso agrupados em } 11 \text { categorias. Ressaltam a } \\
\text { importância do apoio da gestão como principal fator de } \\
\text { sucesso desta transição. }\end{array}$ & $\begin{array}{l}\text { Agile } \\
\text { transformation } \\
\text { process }\end{array}$ \\
\hline $\begin{array}{l}\text { Lan Cao } \\
\text { Kannan Mohan } \\
\text { Peng Xu } \\
\text { Balasubramaniam Ramesh }\end{array}$ & $\begin{array}{l}\text { A framework for adapting agile } \\
\text { development methodologies }\end{array}$ & 2009 & $\begin{array}{l}\text { Analisam como diferentes modelos de desenvolvimento } \\
\text { de software podem ser adaptados para a utilização em } \\
\text { diversos contextos, através do método Adaptive } \\
\text { Structuration Theory (AST). }\end{array}$ & $\begin{array}{l}\text { Agile process } \\
\quad \text { tailoring }\end{array}$ \\
\hline $\begin{array}{l}\text { Miloš Jovanovic } \\
\text { Antonia Mas } \\
\text { Antoni-Lluís Mesquida } \\
\text { Bojan Lali }\end{array}$ & $\begin{array}{l}\text { Transition of organizational } \\
\text { roles in Agile transformation } \\
\text { process: A grounded theory } \\
\text { approach }\end{array}$ & 2017 & $\begin{array}{l}\text { Realizam um estudo com } 5 \text { equipes de software em uma } \\
\text { grande organização espanhola, utilizando a Grounded } \\
\text { Theory para analisar a transformação nos papéis } \\
\text { ocorrida depois da implantação ágil. O objetivo foi } \\
\text { investigar o processo de transformação e identificar os } \\
\text { principais desafios e estratégias para solucioná-los. }\end{array}$ & $\begin{array}{l}\text { Agile } \\
\text { transformation } \\
\text { process } \\
\text { Agile adoption } \\
\text { challenges }\end{array}$ \\
\hline $\begin{array}{l}\text { Peggy Gregory } \\
\text { Leonor Barroca } \\
\text { Helen Sharp } \\
\text { Advait Deshpande } \\
\text { Katie Taylor }\end{array}$ & $\begin{array}{l}\text { The challenges that challenge: } \\
\text { Engaging with agile } \\
\text { practitioners' concerns }\end{array}$ & 2016 & $\begin{array}{l}\text { Descrevem os desafios encontrados pelos agilistas, } \\
\text { agrupados em } 7 \text { categorias e } 27 \text { subcategorias. }\end{array}$ & $\begin{array}{l}\text { Agile adoption } \\
\text { challenge }\end{array}$ \\
\hline
\end{tabular}


(Continuação)

\begin{tabular}{|c|c|c|c|c|}
\hline AUTOR & TÍTULO & DATA & RESUMO & $\begin{array}{l}\text { PALA VRAS- } \\
\text { CHAVE }\end{array}$ \\
\hline $\begin{array}{l}\text { Taghi Javdani Gandomani } \\
\text { Hazura Zulzalil } \\
\text { Abdul Azim Abdul Ghani } \\
\text { Abu Bakar Md. Sultan }\end{array}$ & $\begin{array}{l}\text { Towards Comprehensive and } \\
\text { Disciplined Change Management } \\
\text { Strategy in Agile } \\
\text { Transformation Process }\end{array}$ & 2013 & $\begin{array}{l}\text { Discutem o processo de transformação ágil em uma } \\
\text { perspectiva mais ampla, considerando a estratégia de } \\
\text { change management. }\end{array}$ & $\begin{array}{l}\text { Agile } \\
\text { transformation } \\
\text { process } \\
\text { Agile adoption } \\
\text { challenges }\end{array}$ \\
\hline $\begin{array}{l}\text { Taghi Javdani Gandomani } \\
\text { Hazura Zulzalil } \\
\text { Abdul Azim Abdul Ghani } \\
\text { Abu Bakar Md. Sultan } \\
\text { Mina Ziaei Nafchi }\end{array}$ & $\begin{array}{l}\text { Obstacles in moving to agile } \\
\text { software development methods }\end{array}$ & 2013 & $\begin{array}{l}\text { Focam no estudo dos desafios das organizações durante } \\
\text { a transição ágil, classificados em quatro categorias: } \\
\text { organização e gestão; pessoas; processo; e ferramentas. }\end{array}$ & $\begin{array}{l}\text { Agile adoption } \\
\text { challenge }\end{array}$ \\
\hline $\begin{array}{l}\text { Taghi Javdani Gandomani } \\
\text { Hazura Zulzalil, } \\
\text { Abdul Azim Abdul Ghani, } \\
\text { Abu Bakar Md. Sultan } \\
\text { Khaironi Yatim Sharif }\end{array}$ & $\begin{array}{l}\text { How Human Aspects Impress } \\
\text { Agile Software Development } \\
\text { Transition and Adoption }\end{array}$ & 2014 & $\begin{array}{l}\text { Focam nos aspectos humanos da transformação ágil, por } \\
\text { meio de um estudo com } 32 \text { Agile Experts realizado } \\
\text { através do método Grounded Theory. }\end{array}$ & $\begin{array}{l}\text { Agile } \\
\text { transformation } \\
\text { process }\end{array}$ \\
\hline $\begin{array}{l}\text { Taghi Javdani Gandomani } \\
\text { Mina Ziaei Nafchi }\end{array}$ & $\begin{array}{l}\text { An empirically developed } \\
\text { framework for Agile transition }\end{array}$ & 2015 & $\begin{array}{l}\text { Propõem um framework para a transição para o modelo } \\
\text { ágil, utilizando o método Grounded Theory. }\end{array}$ & $\begin{array}{l}\text { Agile Transition } \\
\text { Framework } \\
\text { Agile } \\
\text { transformation } \\
\text { process } \\
\end{array}$ \\
\hline
\end{tabular}

Fonte: Quadro elaborado pela autora. 


\section{APÊNDICE B - DESAFIOS DE PROCESSOS}

\begin{tabular}{|c|c|c|c|c|c|}
\hline \multicolumn{6}{|c|}{ PROCESSOS } \\
\hline UA & Categoria & Desafios encontrados & Recomendações propostas & Autores & Questionário da entrevista \\
\hline 1 & $\begin{array}{l}\text { Transição Big } \\
\text { Bang }\end{array}$ & $\begin{array}{l}\text { A transição total do modelo } \\
\text { tradicional para o ágil pode } \\
\text { gerar impacto nos projetos, } \\
\text { devido aos novos processos e à } \\
\text { cultura ágil, que possuem } \\
\text { maior autonomia em relação } \\
\text { aos processos tradicionais. }\end{array}$ & $\begin{array}{l}\text { Realizar a transição gradativamente do } \\
\text { modelo tradicional para o ágil, priorizando } \\
\text { as práticas ágeis a serem implantadas e } \\
\text { incrementando-as iterativamente. } \\
\text { Implementar um projeto piloto para analisar } \\
\text { a integração entre os processos tradicionais } \\
\text { e os ágeis, e ampliar para os demais projetos } \\
\text { à medida que os processos forem sendo } \\
\text { alinhados. }\end{array}$ & $\begin{array}{l}\text { COHN; FORD (2003) } \\
\text { DIKERT; } \\
\text { PAASIVAARA; } \\
\text { LASSENIUS (2016). }\end{array}$ & $\begin{array}{l}\text { Q3: A implementação foi } \\
\text { realizada de forma gradual, } \\
\text { contínua, iterativa ou Big Bang? } \\
\text { Foi utilizado um projeto piloto } \\
\text { para a transição? } \\
\text { Q6: Houve algum período em que } \\
\text { os modelos híbridos, com práticas } \\
\text { e projetos tradicionais e ágeis, } \\
\text { foram executados } \\
\text { simultaneamente? }\end{array}$ \\
\hline 2 & $\begin{array}{l}\text { Preparação } \\
\text { para a transição } \\
\text { ágil }\end{array}$ & $\begin{array}{l}\text { As organizações devem ter um } \\
\text { motivador claro para a } \\
\text { transição ágil, que justifique a } \\
\text { adoção deste modelo. Além } \\
\text { disso, devem estar preparadas } \\
\text { para a mudança de } \\
\text { mentalidade. }\end{array}$ & $\begin{array}{l}\text { Ter um motivador claro para a realização da } \\
\text { transição ágil, que justifique a adoção deste } \\
\text { modelo. } \\
\text { Realizar um assessment prévio, que defina } \\
\text { se a organização está preparada para esta } \\
\text { mudança. } \\
\text { Adotar um framework de transição para } \\
\text { determinar os passos a serem adotados. }\end{array}$ & $\begin{array}{l}\text { CHINIFOROOSHAN } \\
\text { ESFAHANI (2012) } \\
\text { GANDOMANI; } \\
\text { NAFCHI (2015) } \\
\text { SIDKY; ARTHUR: } \\
\text { BOHNER (2007). }\end{array}$ & $\begin{array}{l}\text { Q1: Qual foi o principal } \\
\text { motivador para a empresa decidir } \\
\text { pelo projeto de transformação } \\
\text { ágil? } \\
\text { Q2: Houve assessment prévio } \\
\text { quanto à viabilidade da transição } \\
\text { e o alinhamento com os objetivos } \\
\text { estratégicos? } \\
\text { Q5: Houve a aplicação de um } \\
\text { processo de transição ou } \\
\text { framework? } \\
\text { Q28: A empresa estava preparada } \\
\text { para a transição? }\end{array}$ \\
\hline
\end{tabular}




\begin{tabular}{|c|c|c|c|c|c|}
\hline \multicolumn{6}{|c|}{ PROCESSOS (Continuação) } \\
\hline UA & Categoria & Desafios encontrados & Recomendações propostas & Autores & Questionário da entrevista \\
\hline 3 & $\begin{array}{l}\text { Resultados da } \\
\text { transição }\end{array}$ & $\begin{array}{l}\text { A transição total do modelo } \\
\text { tradicional para o ágil pode } \\
\text { gerar impacto nos projetos e na } \\
\text { cultura da equipe e, } \\
\text { consequentemente, nos } \\
\text { resultados da transição. }\end{array}$ & $\begin{array}{l}\text { A organização deve adotar um processo } \\
\text { de melhoria contínua, priorizando algumas } \\
\text { práticas e evoluindo de acordo com a } \\
\text { adaptação da equipe com as práticas já } \\
\text { aplicadas e com os resultados obtidos. } \\
\text { Os resultados do modelo ágil devem ser } \\
\text { medidos e comparados com os resultados } \\
\text { anteriores, no modelo tradicional, para } \\
\text { apoiar a evolução do processo. }\end{array}$ & $\begin{array}{l}\text { BOEHM; TURNER } \\
\text { (2003) } \\
\text { GANDOMANI; } \\
\text { NAFCHI (2015) } \\
\text { SIDKY; ARTHUR; } \\
\text { BOHNER (2007). }\end{array}$ & $\begin{array}{l}\text { Q21: O que mudou nos projetos } \\
\text { depois da transição para o modelo } \\
\text { ágil? O que melhorou ou piorou } \\
\text { (tempo, custo, qualidade)? } \\
\text { Q26: Você acredita que os } \\
\text { objetivos da transformação } \\
\text { (motivadores) foram atingidos com } \\
\text { a transição ágil? } \\
\text { Q27: Houve assessment dos } \\
\text { resultados obtidos depois da } \\
\text { transição e comparação com os } \\
\text { resultados anteriores para medir o } \\
\text { impacto com métricas e } \\
\text { indicadores? } \\
\text { Q24: A empresa tornou-se mais } \\
\text { inovadora depois da transformação } \\
\text { ágil? } \\
\text { Q29: O que você acredita que } \\
\text { ainda falte mudar para que a } \\
\text { empresa seja mais ágil? }\end{array}$ \\
\hline 4 & $\begin{array}{l}\text { Processos } \\
\text { Organizacionais }\end{array}$ & $\begin{array}{l}\text { Retrabalho e redução da } \\
\text { agilidade, caso a organização } \\
\text { demande a utilização dos } \\
\text { processos tradicionais e dos } \\
\text { ágeis durante o projeto. } \\
\text { Desperdício dos processos } \\
\text { tradicionais que funcionavam } \\
\text { bem e levaram tempo para } \\
\text { serem implementados. }\end{array}$ & $\begin{array}{l}\text { Definir antes do início do projeto quais } \\
\text { processos serão adotados e alinhar entre as } \\
\text { distintas áreas da organização o que será } \\
\text { entregue. } \\
\text { Implementar um projeto piloto para } \\
\text { analisar a integração entre os processos } \\
\text { tradicionais e os ágeis e ampliar para os } \\
\text { demais projetos à medida que os } \\
\text { processos forem sendo alinhados. }\end{array}$ & $\begin{array}{l}\text { BOEHM; TURNER } \\
\text { (2005) } \\
\text { MAHANTI (2006). }\end{array}$ & $\begin{array}{l}\text { Q7: A empresa ainda implementa } \\
\text { projetos no modelo tradicional? }\end{array}$ \\
\hline 5 & Estimativas & $\begin{array}{l}\text { Dificuldade em estimar o custo } \\
\text { e o prazo devido à ausência de } \\
\text { planejamento e de escopo } \\
\text { detalhado no início do projeto. }\end{array}$ & $\begin{array}{l}\text { Prover uma estimativa de custo e de prazo } \\
\text { em alto nível no início do projeto e aprovar } \\
\text { o investimento inicial. A cada detalhamento } \\
\text { do projeto, revisar a estimativa. }\end{array}$ & $\begin{array}{l}\text { CAO et al. (2009) } \\
\text { COHN; FORD (2003). }\end{array}$ & $\begin{array}{l}\text { Q13: Como é feita a estimativa de } \\
\text { custo e de prazo do projeto? A } \\
\text { organização trabalha com o conceito } \\
\text { de MVP? }\end{array}$ \\
\hline
\end{tabular}




\begin{tabular}{|c|c|c|c|c|c|}
\hline \multicolumn{6}{|c|}{ PROCESSOS (Continuação) } \\
\hline UA & Categoria & Desafios encontrados & Recomendações propostas & Autores & Questionário da entrevista \\
\hline 6 & $\begin{array}{l}\text { Relatórios de } \\
\text { Status }\end{array}$ & $\begin{array}{l}\text { Acompanhamento da gestão } \\
\text { para verificar se o projeto está } \\
\text { sendo executado de acordo } \\
\text { com sua expectativa. }\end{array}$ & $\begin{array}{l}\text { Definir milestones adaptados ao modelo } \\
\text { ágil e criar relatórios básicos com } \\
\text { indicadores neles baseados. } \\
\text { Medir o progresso através do gráfico de } \\
\text { burndown. } \\
\text { Avaliar o progresso do projeto baseado na } \\
\text { entrega do software funcionando. }\end{array}$ & $\begin{array}{l}\text { BOEHM; TURNER } \\
\text { (2005) } \\
\text { COHN; FORD (2003) } \\
\text { ESPINOSA-CURIEL } \\
\text { et al. }(2018) \\
\text { GREGORY } \text { et al. } \\
\text { (2016) } \\
\text { SCHWABER; } \\
\text { SUTHERLAND } \\
\text { (2017). }\end{array}$ & $\begin{array}{l}\text { Q14: Como é feito o } \\
\text { acompanhamento de acordo com } \\
\text { esta estimativa? A gestão da } \\
\text { empresa está confortável com estes } \\
\text { reportes? }\end{array}$ \\
\hline 7 & Contratos & $\begin{array}{l}\text { Dificuldade em estimar o custo } \\
\text { e prazo pelos clientes ou } \\
\text { fornecedores para definir o } \\
\text { modelo de contrato e de } \\
\text { faturamento, devido à ausência } \\
\text { de planejamento e de escopo } \\
\text { detalhado no início do projeto. }\end{array}$ & $\begin{array}{l}\text { Adaptar o modelo de contrato com clientes } \\
\text { ou com fornecedores, redefinindo métricas } \\
\text { e formas de pagamento. }\end{array}$ & $\begin{array}{l}\text { BOEHM; TURNER } \\
\text { (2005) } \\
\text { GREGORY et al. } \\
(2016) \text {. }\end{array}$ & $\begin{array}{l}\text { Na entrevista, não foi incluída } \\
\text { nenhuma questão específica quanto } \\
\text { a este item. }\end{array}$ \\
\hline 8 & Comunicação & $\begin{array}{l}\text { A nova forma de comunicação } \\
\text { do modelo ágil requer maior } \\
\text { integração e comunicação entre } \\
\text { a equipe. }\end{array}$ & $\begin{array}{l}\text { Definir um novo modelo de comunicação } \\
\text { entre a equipe (formal, informal, verbal e } \\
\text { escrita), baseado na cooperação e na } \\
\text { colaboração. }\end{array}$ & $\begin{array}{l}\text { ESPINOSA-CURIEL } \\
\text { et al. }(2018) \\
\text { GANDOMANI } \text { et al. } \\
\text { (2013) }\end{array}$ & $\begin{array}{l}\text { Q17: A comunicação entre as } \\
\text { equipes melhorou? Atualmente, } \\
\text { como é a comunicação interna da } \\
\text { equipe e com as outras áreas? Como } \\
\text { era anteriormente? }\end{array}$ \\
\hline 9 & $\begin{array}{l}\text { Gestão do } \\
\text { conhecimento }\end{array}$ & $\begin{array}{l}\text { A equipe pode não se sentir } \\
\text { confiante em compartilhar } \\
\text { conhecimento com os demais } \\
\text { membros. }\end{array}$ & $\begin{array}{l}\text { Criar um ambiente apropriado que estimule } \\
\text { o compartilhamento do conhecimento entre } \\
\text { a equipe. } \\
\text { Utilizar mentores para a transferência de } \\
\text { conhecimento aos membros da equipe } \\
\text { menos experientes. }\end{array}$ & $\begin{array}{l}\text { CONBOY et al. }(2011) \\
\text { CHAN; THONG } \\
\text { (2009) } \\
\text { ESPINOSA-CURIEL } \\
\text { et al. (2018) } \\
\text { GREGORY } \text { et al. } \\
\text { (2016). }\end{array}$ & $\begin{array}{l}\text { Na entrevista, não foi incluída } \\
\text { nenhuma questão específica quanto } \\
\text { a este item. }\end{array}$ \\
\hline
\end{tabular}




\begin{tabular}{|c|c|c|c|c|c|}
\hline \multicolumn{6}{|c|}{ PROCESSOS (Continuação) } \\
\hline UA & Categoria & Desafios encontrados & Recomendações propostas & Autores & Questionário da entrevista \\
\hline 10 & Documentação & $\begin{array}{l}\text { Como a documentação formal } \\
\text { será reduzida, pode haver um } \\
\text { impacto de conhecimento com } \\
\text { a transição ágil. }\end{array}$ & $\begin{array}{l}\text { Manter a documentação do projeto de } \\
\text { forma mais flexível do que no modelo } \\
\text { tradicional, porém, com o mínimo de } \\
\text { informações quanto ao projeto para que a } \\
\text { equipe não perca nenhuma delas. }\end{array}$ & $\begin{array}{l}\text { ESPINOSA-CURIEL } \\
\text { et al. }(2018) \\
\text { GREGORY } \text { et al. } \\
(2016)\end{array}$ & $\begin{array}{l}\text { Na entrevista, não foi incluída } \\
\text { nenhuma questão específica quanto } \\
\text { a este item. }\end{array}$ \\
\hline 11 & $\begin{array}{l}\text { Integração com } \\
\text { outras áreas }\end{array}$ & $\begin{array}{l}\text { Dificuldade quando as outras } \\
\text { áreas do projeto não estão } \\
\text { adotando a cultura ágil. }\end{array}$ & $\begin{array}{l}\text { Comunicar (top-down) a importância de } \\
\text { utilizar o mesmo modelo inter-áreas e os } \\
\text { impactos pelo fato de as equipes não } \\
\text { estarem em sintonia. }\end{array}$ & $\begin{array}{l}\text { COHN; FORD (2003) } \\
\text { DIKERT; } \\
\text { PAASIVAARA; } \\
\text { LASSENIUS (2016). }\end{array}$ & $\begin{array}{l}\text { Q22: O modelo ágil é utilizado por } \\
\text { todas as áreas da organização? }\end{array}$ \\
\hline
\end{tabular}

Fonte: Quadro elaborado pela autora. 


\section{APENNDICE C - DESAFIOS DE PESSOAS}

\begin{tabular}{|c|c|c|c|c|c|}
\hline \multicolumn{6}{|c|}{ PESSOAS } \\
\hline UA & Categoria & Desafios encontrados & Recomendações propostas & Autores & Questionário da entrevista \\
\hline 12 & $\begin{array}{l}\text { Organização da } \\
\text { equipe }\end{array}$ & $\begin{array}{l}\text { Como os modelos ágeis são } \\
\text { os mais recomendados para } \\
\text { equipes pequenas, é um } \\
\text { grande desafio implementá- } \\
\text { los em projetos grandes e } \\
\text { com equipes distribuídas. }\end{array}$ & $\begin{array}{l}\text { Dividir os projetos grandes em várias } \\
\text { equipes menores. } \\
\text { Alocar equipes distribuídas no mesmo } \\
\text { lugar no início do projeto. }\end{array}$ & $\begin{array}{l}\text { COHN; FORD (2003) } \\
\text { GANDOMANI et al. } \\
\text { (2013) } \\
\text { GREGORY et al. }(2016) \\
\text { JOVANOVIĆ et al. } \\
(2017)\end{array}$ & $\begin{array}{l}\text { Na entrevista, não foi incluída } \\
\text { nenhuma questão específica quanto a } \\
\text { este item. }\end{array}$ \\
\hline 13 & $\begin{array}{l}\text { Papéis e } \\
\text { responsabilidades }\end{array}$ & $\begin{array}{l}\text { Necessidade de equipe de } \\
\text { alta performance com perfil } \\
\text { multidisciplinar e auto } \\
\text { motivável. }\end{array}$ & $\begin{array}{l}\text { Treinar toda a equipe do projeto no } \\
\text { modelo ágil, em negócio e em soft } \\
\text { skills. } \\
\text { Alocar membros da equipe em um } \\
\text { único projeto para manter o foco e a } \\
\text { agilidade. }\end{array}$ & $\begin{array}{l}\text { CONBOY et al. }(2011) \\
\text { ESPINOSA-CURIEL } \text { et } \\
\text { al. }(2018) \\
\text { GANDOMANI; NAFCHI } \\
\text { (2016) } \\
\text { GREGORY et al. }(2016) \\
\text { JOVANOVIC } \text { et al. } \\
\text { (2017). }\end{array}$ & $\begin{array}{l}\text { Q16: Quais os impactos nas } \\
\text { atividades e skills da equipe antes e } \\
\text { depois da transição? }\end{array}$ \\
\hline 14 & Tomada de decisão & $\begin{array}{l}\text { Os Gerentes de Projetos não } \\
\text { conseguem abandonar seu } \\
\text { papel de autoridade e } \\
\text { apresentam resistência } \\
\text { quanto à transição ágil, } \\
\text { mantendo a liderança } \\
\text { baseada no comando e } \\
\text { controle. A equipe do projeto } \\
\text { acaba mantendo uma postura } \\
\text { passiva e não tomando para } \\
\text { si a responsabilidade do } \\
\text { projeto. }\end{array}$ & $\begin{array}{l}\text { O Gerente de Projetos deve assumir } \\
\text { o papel de facilitador da equipe e } \\
\text { não mais de líder, estimulando todos } \\
\text { a contribuírem com a tomada de } \\
\text { decisão do projeto. } \\
\text { A equipe do projeto deve assumir } \\
\text { uma posição de protagonismo e ser } \\
\text { auto organizável. }\end{array}$ & $\begin{array}{l}\text { BOEHM; TURNER (2005) } \\
\text { CHEN; RAVICHANDAR; } \\
\text { PROCTOR (2016) } \\
\text { CONBOY } \text { et al. }(2011) \\
\text { ESPINOSA-CURIEL } \text { et } \text { al. } \\
\text { (2018) } \\
\text { GANDOMANI } \text { et al. } \\
\text { (2013, 2014) } \\
\text { GANDOMANI; NAFCHI } \\
\text { (2016) } \\
\text { NERUR; MAHAPATRA; } \\
\text { MANGALARAJ (2005) }\end{array}$ & $\begin{array}{l}\text { Q19: Houve mudança no papel de } \\
\text { Gerente de Projetos antes e depois } \\
\text { da transição? Houve resistência? } \\
\text { Q20: As equipes possuem autonomia } \\
\text { para a tomada de decisão? }\end{array}$ \\
\hline
\end{tabular}




\begin{tabular}{|c|c|c|c|c|c|}
\hline \multicolumn{6}{|c|}{ PESSOAS (Continuação) } \\
\hline UA & Categoria & Desafios encontrados & Recomendações propostas & Autores & Questionário da entrevista \\
\hline 15 & Colaboração & $\begin{array}{l}\text { Quando as equipes do } \\
\text { projeto não conseguem } \\
\text { mudar a mentalidade para um } \\
\text { perfil de colaboração, a } \\
\text { transição torna-se bem mais } \\
\text { difícil. }\end{array}$ & $\begin{array}{l}\text { Todos os membros da equipe devem } \\
\text { assumir um papel colaborativo e } \\
\text { manter o onwership compartilhado } \\
\text { do projeto }\end{array}$ & $\begin{array}{l}\text { CHAN; THONG (2009) } \\
\text { CHEN; RAVICHANDAR; } \\
\text { PROCTOR (2016) } \\
\text { DIKERT; PAASIVAARA; } \\
\text { LASSENIUS (2016) } \\
\text { ESPINOSA-CURIEL } \text { et al. } \\
\text { (2018) } \\
\text { GANDOMANI } \text { et al. (2013) } \\
\text { GREGORY et al. (2016) } \\
\text { GANDOMANI; NAFCHI } \\
\text { (2016); } \\
\text { JOVANOVIC } \text { et al. (2017); } \\
\text { NERUR; MAHAPATRA; } \\
\text { MANGALARAJ (2005) }\end{array}$ & $\begin{array}{l}\text { Q18: A colaboração entre os } \\
\text { membros da equipe melhorou? Os } \\
\text { membros da equipe sentem-se } \\
\text { responsáveis pelo projeto } \\
\text { (ownership)? }\end{array}$ \\
\hline 16 & $\begin{array}{l}\text { Resistência à } \\
\text { mudança }\end{array}$ & $\begin{array}{l}\text { Como a maioria das } \\
\text { mudanças é realizada no } \\
\text { âmbito das pessoas, a equipe } \\
\text { pode oferecer resistência e } \\
\text { ter dificuldade de adaptação } \\
\text { às práticas ágeis. }\end{array}$ & $\begin{array}{l}\text { A gestão deve comunicar à equipe } \\
\text { os objetivos da transição, para que } \\
\text { ela tenha expectativas claras quanto } \\
\text { ao processo e às práticas ágeis. } \\
\text { Também deve haver a } \\
\text { obrigatoriedade de adoção do novo } \\
\text { processo na organização, caso } \\
\text { contrário, a equipe não se sentirá } \\
\text { motivada para mudar. }\end{array}$ & $\begin{array}{l}\text { CONBOY et al. (2011) } \\
\text { DIKERT; PAASIVAARA; } \\
\text { LASSENIUS (2016) } \\
\text { GANDOMANI } \text { et al. (2014) } \\
\text { GANDOMANI; NAFCHI } \\
\text { (2015, 2016) } \\
\text { JOVANOVIĆ et al. (2017) } \\
\text { MAHANTI (2006) } \\
\text { JOVANOVIC et al. (2017) }\end{array}$ & $\begin{array}{l}\text { Q8: A gestão da empresa informou } \\
\text { sobre os objetivos da mudança } \\
\text { para o modelo ágil? Houve } \\
\text { transparência durante o processo } \\
\text { de transição? } \\
\text { Q12: A equipe e as demais áreas } \\
\text { acreditavam na implantação do } \\
\text { modelo ágil? Houve aceitação ou } \\
\text { resistência das áreas envolvidas? }\end{array}$ \\
\hline 17 & Cliente dedicado & $\begin{array}{l}\text { Clientes são considerados } \\
\text { membros da equipe e são } \\
\text { responsáveis pelas decisões } \\
\text { de escopo e pelas } \\
\text { priorizações durante o } \\
\text { projeto. } \\
\text { A falta de proximidade e de } \\
\text { engajamento do cliente pode } \\
\text { acarretar atraso na tomada de } \\
\text { decisões. }\end{array}$ & $\begin{array}{l}\text { Manter clientes dedicados ao } \\
\text { projeto, com o mesmo papel de } \\
\text { colaboração e de comunicação de } \\
\text { que os demais membros da equipe. } \\
\text { Criar um entregável a cada intervalo } \\
\text { de tempo fixo que possa ser } \\
\text { validado pelo cliente. } \\
\text { Treinar os clientes nos processos e } \\
\text { valores do modelo ágil. }\end{array}$ & $\begin{array}{l}\text { CHAN; THONG (2009) } \\
\text { GANDOMANI et al. (2013) } \\
\text { JOVANOVIĆ et al. (2017) } \\
\text { ESPINOSA-CURIEL } \text { et al. } \\
\text { (2018) } \\
\text { JOVANOVIC et al. (2017) }\end{array}$ & $\begin{array}{l}\text { Na entrevista, não foi incluída } \\
\text { nenhuma questão específica } \\
\text { quanto a este item. }\end{array}$ \\
\hline
\end{tabular}




\begin{tabular}{|c|c|c|c|c|c|}
\hline \multicolumn{6}{|c|}{ PESSOAS (Continuação) } \\
\hline $\mathbf{U A}$ & Categoria & Desafios encontrados & Recomendações propostas & Autores & Questionário da entrevista \\
\hline 18 & $\begin{array}{l}\text { Visibilidade da } \\
\text { equipe }\end{array}$ & $\begin{array}{l}\text { A equipe pode se sentir } \\
\text { intimidada devido à alta } \\
\text { visibilidade do seu trabalho } \\
\text { com os níveis executivos. }\end{array}$ & $\begin{array}{l}\text { Empoderar os membros da equipe e } \\
\text { lhes proporcionar um ambiente } \\
\text { confortável, no qual possam } \\
\text { expressar sua opinião frente à equipe } \\
\text { do projeto e aos níveis executivos. } \\
\text { Treinar a equipe em skills técnicos e } \\
\text { de comunicação para passar maior } \\
\text { segurança. } \\
\text { Utilizar modelo de mentores e pair } \\
\text { programming para aumentar o } \\
\text { conhecimento da equipe. }\end{array}$ & $\begin{array}{l}\text { DIKERT; PAASIVAARA; } \\
\text { LASSENIUS (2016) } \\
\text { ESPINOSA-CURIEL } \text { et al. } \\
(2018)\end{array}$ & $\begin{array}{l}\text { Na entrevista, não foi incluída } \\
\text { nenhuma questão específica } \\
\text { quanto a este item. }\end{array}$ \\
\hline 19 & $\begin{array}{l}\text { Mudança de } \\
\text { mindset }\end{array}$ & $\begin{array}{l}\text { Necessidade de aplicar os } \\
\text { princípios e valores ágeis } \\
\text { (colaboração, comunicação, } \\
\text { trabalho em equipe), não } \\
\text { somente as práticas (sprints, } \\
\text { equipe do projeto, } \\
\text { cerimônias). }\end{array}$ & $\begin{array}{l}\text { Treinar a equipe do projeto no } \\
\text { modelo ágil. } \\
\text { Alocar um coach externo à } \\
\text { organização para apoiar no processo } \\
\text { de transição. } \\
\text { Definir uma equipe de transição para } \\
\text { apoiar na aplicação do modelo. }\end{array}$ & $\begin{array}{l}\text { CONBOY et al. (2011) } \\
\text { DIKERT; PAASIVAARA; } \\
\text { LASSENIUS (2016) } \\
\text { ESPINOSA-CURIEL } \text { et al. } \\
\text { (2018) } \\
\text { GANDOMANI et al. (2013, } \\
\text { 2014) } \\
\text { GREGORY et al. (2016) } \\
\text { GANDOMANI; NAFCHI } \\
\text { (2016) } \\
\text { JOVANOVIC } \text { et al. (2017) } \\
\text { NERUR; MAHAPATRA; } \\
\text { MANGALARAJ (2005) }\end{array}$ & $\begin{array}{l}\text { Q4: Houve a alocação de uma } \\
\text { equipe de transformação ou de um } \\
\text { coach para auxiliar na transição? } \\
\text { Você acha que foi importante para } \\
\text { a transformação? } \\
\text { Q23: Houve mudança de mindset } \\
\text { ou de cultura da empresa? }\end{array}$ \\
\hline
\end{tabular}

Fonte: Quadro elaborado pela autora. 


\section{APÊNDICE D - DESAFIOS DE GESTÃO}

\begin{tabular}{|c|c|c|c|c|c|}
\hline \multicolumn{6}{|c|}{ GESTÃO } \\
\hline UA & Categoria & Desafios encontrados & Recomendações propostas & Autores & Questionário da entrevista \\
\hline 20 & Apoio da gestão & $\begin{array}{l}\text { A gestão da organização } \\
\text { pode agir como uma } \\
\text { barreira na implantação dos } \\
\text { valores ágeis. }\end{array}$ & $\begin{array}{l}\text { Aplicar os valores ágeis de } \\
\text { comunicação e de gestão } \\
\text { descentralizada, dando todo o apoio } \\
\text { necessário ao projeto. } \\
\text { Aceitar a mudança de mindset do } \\
\text { modelo ágil em relação ao modelo } \\
\text { tradicional. }\end{array}$ & $\begin{array}{l}\text { CAO et al. (2009) } \\
\text { CHAN; THONG (2009) } \\
\text { CHEN; RAVICHANDAR; } \\
\text { PROCTOR (2016) } \\
\text { CONBOY et al. }(2011) \\
\text { DIKERT; PAASIVAARA; } \\
\text { LASSENIUS (2016) } \\
\text { GANDOMANI; NAFCHI (2015, } \\
\text { 2016) } \\
\text { JOVANOVIĆ } \text { et al. } \text { (2017) } \\
\text { MAHANTI (2006) } \\
\text { JOVANOVIC (2017) } \\
\text { GANDOMANI } \text { et al. } \text { (2014) }\end{array}$ & $\begin{array}{l}\text { Na entrevista, não foi incluída } \\
\text { nenhuma questão específica } \\
\text { quanto a este item. }\end{array}$ \\
\hline 21 & $\begin{array}{l}\text { Gestão } \\
\text { descentralizada }\end{array}$ & $\begin{array}{l}\text { Modelos tradicionais } \\
\text { pregam a gestão de } \\
\text { comando e controle; } \\
\text { enquanto os ágeis são } \\
\text { baseados na colaboração. } \\
\text { Dificuldade da gestão em } \\
\text { aceitar o modelo } \\
\text { descentralizado, reduzindo } \\
\text { seu poder. }\end{array}$ & $\begin{array}{l}\text { Reduzir o micromanagement dos } \\
\text { níveis gerenciais e delegar a tomada } \\
\text { de decisões. } \\
\text { Redefinir as expectativas de controle } \\
\text { do projeto, tais como estimativas e } \\
\text { relatórios de progresso. }\end{array}$ & $\begin{array}{l}\text { CHEN; RAVICHANDAR; } \\
\text { PROCTOR (2016) } \\
\text { COCKBURN; HIGHSMITH } \\
\text { (2001) } \\
\text { COHN; FORD (2003) } \\
\text { ESPINOSA-CURIEL } \text { et al. } \\
\text { (2018) } \\
\text { GANDOMANI } \text { et al. (2013) } \\
\text { GREGORY et al. (2016) } \\
\text { GANDOMANI; NAFCHI (2016) } \\
\text { NERUR; MAHAPATRA; } \\
\text { MANGALARAJ (2005) }\end{array}$ & $\begin{array}{l}\text { Q9: Houve resistência da gestão } \\
\text { na implantação ágil? }\end{array}$ \\
\hline
\end{tabular}

Fonte: Quadro elaborado pela autora. 


\section{APÊNDICE E - DESAFIOS DA ORGANIZAÇÃO}

\begin{tabular}{|c|c|c|c|c|c|}
\hline \multicolumn{6}{|c|}{ ORGANIZAÇÃO } \\
\hline UA & Categoria & Desafios encontrados & Recomendações propostas & Autores & Questionário da entrevista \\
\hline 22 & $\begin{array}{l}\text { Estrutura } \\
\text { hierárquica }\end{array}$ & $\begin{array}{l}\text { A formação das equipes passa } \\
\text { a ser não mais por áreas } \\
\text { funcionais, e sim por equipes } \\
\text { multidisciplinares, o que } \\
\text { requer uma alteração na } \\
\text { estrutura de cargos. }\end{array}$ & $\begin{array}{l}\text { Modificar os níveis hierárquicos, } \\
\text { reduzindo-os a uma estrutura mais } \\
\text { horizontalizada em toda a } \\
\text { organização. }\end{array}$ & $\begin{array}{l}\text { CONBOY et al. }(2011) \\
\text { GANDOMANI; NAFCHI } \\
(2016)\end{array}$ & $\begin{array}{l}\text { Q15: Quais os impactos na } \\
\text { estrutura de cargos da empresa e } \\
\text { níveis hierárquicos? }\end{array}$ \\
\hline 23 & Treinamento & $\begin{array}{l}\text { A falta de investimento da } \\
\text { organização em treinamento } \\
\text { da equipe no modelo ágil } \\
\text { pode representar um risco } \\
\text { para a transição devido à falta } \\
\text { de conhecimento da equipe } \\
\text { quanto aos processos e aos } \\
\text { valores ágeis. }\end{array}$ & $\begin{array}{l}\text { Realizar treinamento nos processos e } \\
\text { valores ágeis, e também em business } \\
\text { skills e soft skills necessários } \\
\text { (comunicação e cooperação). }\end{array}$ & $\begin{array}{l}\text { CHAN; THONG (2009) } \\
\text { CONBOY et al. (2011) } \\
\text { DIKERT; PAASIVAARA; } \\
\text { LASSENIUS. (2016) } \\
\text { GANDOMANI et al. (2013) } \\
\text { GREGORY et al. }(2016) \\
\text { JOVANOVIĆ } \text { et al. (2017) } \\
\text { MAHANTI (2006) } \\
\text { JOVANOVIC } \text { et al. (2017) }\end{array}$ & $\begin{array}{l}\text { Q11: Houve treinamento da equipe } \\
\text { em novas habilidades } \\
\text { (metodologia ágil, negócio, soft } \\
\text { skills)? } \\
\text { Q10: Houve participação da área } \\
\text { de Recursos Humanos ou de } \\
\text { Change Management durante a } \\
\text { transição? }\end{array}$ \\
\hline 24 & $\begin{array}{l}\text { Contratação de } \\
\text { Profissionais }\end{array}$ & $\begin{array}{l}\text { Devido à } \\
\text { multidisciplinaridade do } \\
\text { modelo ágil, perfis } \\
\text { específicos não são mais } \\
\text { valorizados em organizações } \\
\text { ágeis. }\end{array}$ & $\begin{array}{l}\text { Contratar profissionais qualificados } \\
\text { tanto nas habilidades técnicas quanto } \\
\text { nas de negócios, de acordo com os } \\
\text { valores ágeis. }\end{array}$ & $\begin{array}{l}\text { CONBOY et al. }(2011) \\
\text { MAHANTI (2006) } \\
\text { GREGORY et al. }(2016)\end{array}$ & $\begin{array}{l}\text { Na entrevista, não foi incluída } \\
\text { nenhuma questão específica } \\
\text { quanto a este item. }\end{array}$ \\
\hline 25 & $\begin{array}{l}\text { Avaliação de } \\
\text { Performance }\end{array}$ & $\begin{array}{l}\text { A avaliação de performance } \\
\text { da organização não pode mais } \\
\text { considerar apenas a avaliação } \\
\text { individual dos modelos } \\
\text { tradicionais. }\end{array}$ & $\begin{array}{l}\text { Considerar uma avaliação em equipe, } \\
\text { com critérios de colaboração, } \\
\text { comunicação e interação entre os } \\
\text { funcionários. } \\
\text { Desenvolver novas métricas de } \\
\text { avaliação, considerando indicadores } \\
\text { de performance em grupo e em } \\
\text { sistema de recompensas. } \\
\text { Adaptar a gestão de carreira para que } \\
\text { haja maior flexibilidade e } \\
\text { oportunidades internas para aumentar } \\
\text { a motivação da equipe. }\end{array}$ & $\begin{array}{l}\text { CHAN; THONG (2009) } \\
\text { CHEN; RAVICHANDAR; } \\
\text { PROCTOR (2016) } \\
\text { CONBOY } \text { et al. }(2011) \\
\text { ESPINOSA-CURIEL } \text { et al. } \\
\text { (2018) } \\
\text { GANDOMANI; NAFCHI } \\
(2016)\end{array}$ & $\begin{array}{l}\text { Na entrevista, não foi incluída } \\
\text { nenhuma questão específica } \\
\text { quanto a este item. }\end{array}$ \\
\hline
\end{tabular}

Fonte: Quadro elaborado pela autora. 


\section{APENNDICE F - PERFIL DOS ENTREVISTADOS E DAS RESPECTIVAS ORGANIZAÇÕES}

\begin{tabular}{|c|c|c|c|c|c|c|c|c|c|c|c|c|}
\hline \multicolumn{6}{|c|}{ Perfil dos Entrevistados } & \multicolumn{7}{|c|}{ Perfil das Organizações } \\
\hline $\begin{array}{l}\text { Entre- } \\
\text { vis- } \\
\text { tado }\end{array}$ & Gênero & Idade & Cargo & $\begin{array}{l}\text { Tempo de } \\
\text { expe- } \\
\text { riência } \\
\text { em } \\
\text { projetos }\end{array}$ & $\begin{array}{l}\text { Tempo de } \\
\text { experiência } \\
\text { ágil }\end{array}$ & Empresa & Segmento & $\begin{array}{l}\text { Naciona- } \\
\text { lidade }\end{array}$ & $\begin{array}{l}\text { Tama- } \\
\text { nho } \\
\text { (Brasil) }\end{array}$ & $\begin{array}{l}\text { Início da } \\
\text { transi- } \\
\text { ção }\end{array}$ & $\begin{array}{l}\text { Dura- } \\
\text { ção da } \\
\text { transi- } \\
\text { ção }\end{array}$ & $\begin{array}{l}\text { Transi- } \\
\text { ção con- } \\
\text { cluída? }\end{array}$ \\
\hline E1 & Feminino & 44 & $\begin{array}{l}\text { Gerente de } \\
\text { Projetos }\end{array}$ & 15 anos & 1 ano & A & $\begin{array}{l}\text { Mercado de } \\
\text { Capitais }\end{array}$ & Nacional & 2.800 & 2018 & 2 anos & Não \\
\hline E2 & Feminino & 33 & $\begin{array}{l}\text { Coordenadora de } \\
\text { Projetos }\end{array}$ & 13 anos & 6 anos & B & Adquirência & Nacional & 2.500 & 2017 & 3 anos & Não \\
\hline E3 & Feminino & 37 & Product Owner & 10 anos & 5 anos & B & Adquirência & Nacional & 2.500 & 2017 & 3 anos & Não \\
\hline E4 & Feminino & 30 & Agile Coach & 12 anos & 4 anos & $\mathrm{C}$ & $\mathrm{TI}$ & $\begin{array}{l}\text { Multinacio- } \\
\text { nal }\end{array}$ & 17.400 & 2015 & 5 anos & Sim \\
\hline E5 & Masculino & 41 & Agile Coach & 12 anos & 4 anos & A & $\begin{array}{l}\text { Mercado de } \\
\text { Capitais }\end{array}$ & Nacional & 2.800 & 2018 & 2 anos & Não \\
\hline E6 & Masculino & 37 & $\begin{array}{l}\text { Gerente do } \\
\text { Escritório de } \\
\text { Projetos }\end{array}$ & 13 anos & 8 anos & $\mathrm{D}$ & TI & Nacional & 980 & 2018 & 1 ano & Sim \\
\hline E7 & Feminino & 43 & Agile Coach & 10 anos & 3 anos & $\mathrm{E}$ & Varejo & Nacional & 40.000 & 2018 & 2 anos & Não \\
\hline E8 & Feminino & 51 & Scrum Master & 15 anos & 2 anos & $\mathrm{F}$ & Banco & Nacional & 150 & 2018 & 1 ano & Sim \\
\hline E9 & Feminino & 41 & $\begin{array}{c}\text { Digital } \\
\text { Transformation } \\
\text { Leader }\end{array}$ & 10 anos & 2 anos & G & Banco & Nacional & 1.500 & 2018 & 2 anos & Não \\
\hline E10 & Masculino & 40 & Agile Master & 17 anos & 3 anos & $\mathrm{H}$ & $\begin{array}{l}\text { Telecomuni- } \\
\text { cações }\end{array}$ & $\begin{array}{c}\text { Multinacio- } \\
\text { nal }\end{array}$ & 10.000 & 2019 & 1 ano & Não \\
\hline
\end{tabular}

Fonte: Quadro elaborado pela autora. 


\section{APÊNDICE G - COLETA DE DADOS PRIMÁRIOS - FORMULÁRIO INICIAL}

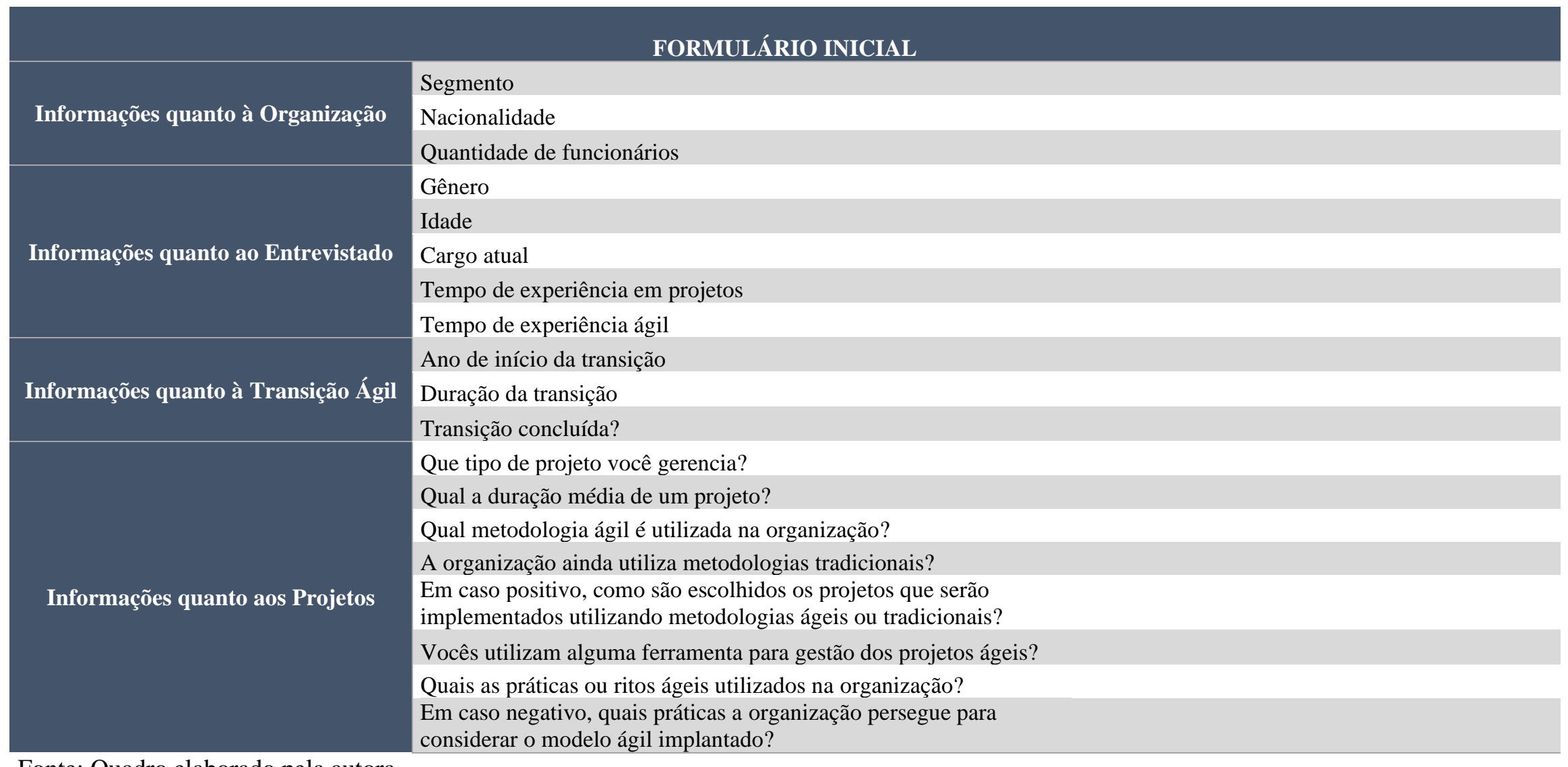

Fonte: Quadro elaborado pela autora. 


\section{APÊNDICE H - QUESTIONÁRIO DA ENTREVISTA}

\begin{tabular}{|c|c|}
\hline Questão & $\begin{array}{l}\text { ROTEIRO DA ENTREVISTA } \\
\text { Processo de Transição para o Modelo ágil }\end{array}$ \\
\hline 1 & Qual foi o principal motivador para a empresa decidir pelo projeto de transformação ágil? \\
\hline 2 & Houve um assessment prévio em relação à viabilidade da transição e alinhamento com os objetivos estratégicos? \\
\hline 3 & A implementação foi realizada de forma gradual, contínua, iterativa ou Big Bang? Foi utilizado um projeto piloto para a transição? \\
\hline 4 & Houve a alocação de uma equipe de transformação ou de um coach para auxiliar na transição? Você acha que foi importante para a transformação? \\
\hline 5 & Houve a aplicação de um processo de transição ou framework? \\
\hline 6 & Houve algum período no qual os modelos híbridos com práticas e projetos tradicionais e ágeis foram executados simultaneamente? \\
\hline 7 & A empresa ainda implementa projetos no modelo tradicional? \\
\hline 8 & A gestão da empresa informou sobre os objetivos da mudança para o modelo ágil? Houve transparência durante o processo de transição? \\
\hline 9 & Houve resistência da gestão na implantação ágil? \\
\hline 10 & Houve a participação da área de Recursos Humanos ou Change Management durante a transição? \\
\hline 11 & Houve treinamento da equipe em novas habilidades (metodologia ágil, negócio e soft skills)? \\
\hline 12 & A equipe e as demais áreas acreditavam na implantação do modelo ágil? Houve aceitação ou resistência das áreas envolvidas? \\
\hline 13 & Como é feita a estimativa de custo e de prazo do projeto? A organização trabalha com o conceito de MVP? \\
\hline 14 & Como é feito o acompanhamento de acordo com esta estimativa? A gestão da empresa está confortável com estes reportes? \\
\hline 15 & Quais os impactos na estrutura de cargos da empresa e níveis hierárquicos? \\
\hline 16 & Quais os impactos nas atividades e skills da equipe antes e depois da transição? \\
\hline
\end{tabular}




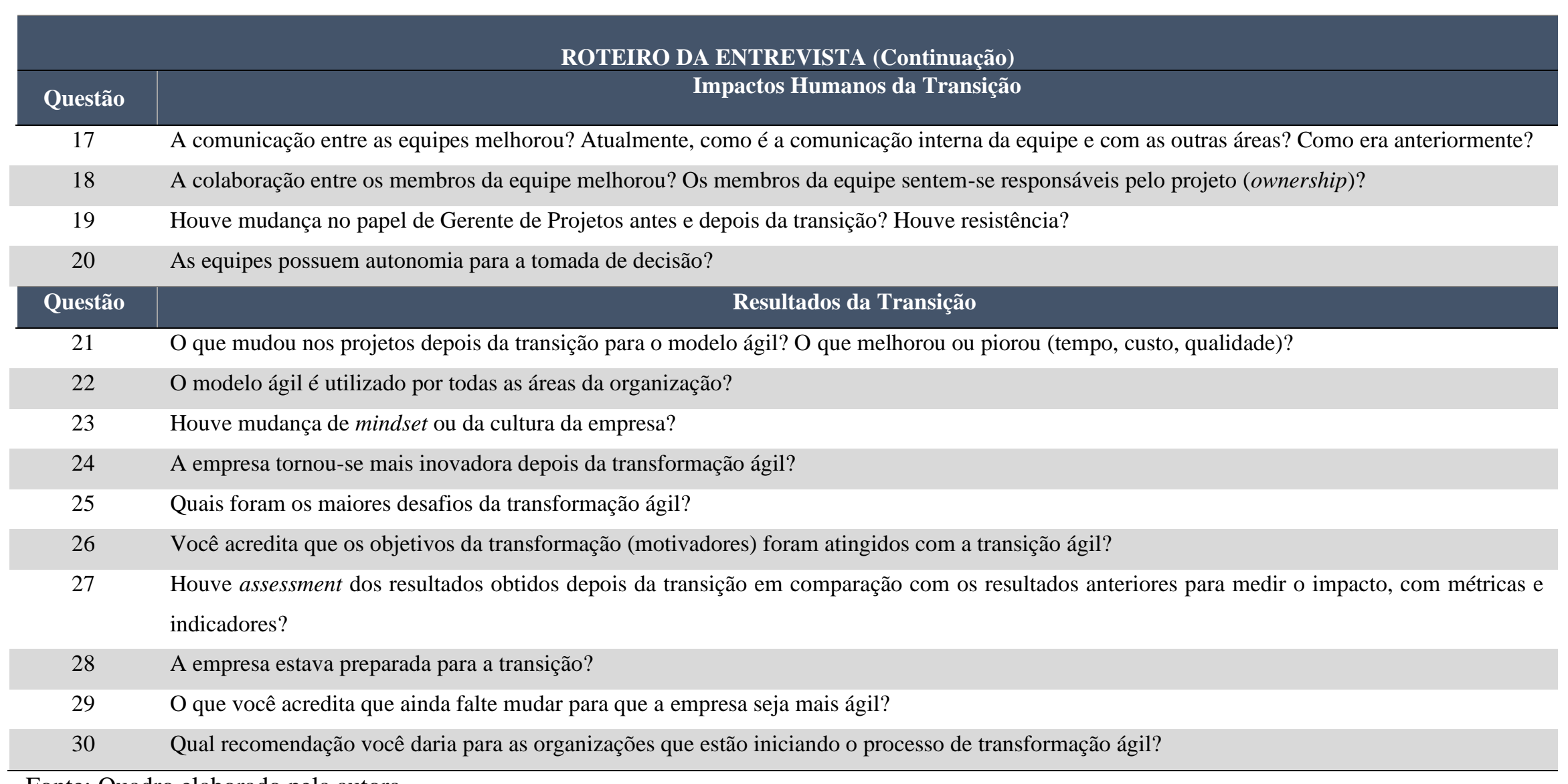

Fonte: Quadro elaborado pela autora. 


\section{APÊNDICE I - CARTA DE APRESENTAÇÃO PARA REALIZAÇÃO DA ENTREVISTA}

Prezado [nome do entrevistado],

O objetivo desta pesquisa é analisar o processo de transição de modelos tradicionais de gestão de projetos de desenvolvimento de softwares (ex. PMP ou outros modelos em cascata) para os modelos ágeis (ex. Scrum, XP etc.).

Para isso, entrevistarei funcionários de diversas organizações que tenham realizado esta transição, seja da área de tecnologia ou seja integrantes da equipe do projeto, tais como Gerentes de Projetos, Scrum Masters, Agile Experts ou Product Owners.

O critério de seleção contemplou apenas organizações que tenham realizado a transformação ágil em seus projetos de desenvolvimento de software (concluída ou em curso), podendo pertencer a qualquer setor, independentemente de seu porte, tempo de existência ou estrutura hierárquica.

As perguntas estão relacionadas com o modelo de gestão de projeto utilizado atualmente na organização; com o processo de transição, visando a analisar os desafios encontrados durante a transição; com as ações para superar estes desafios; e com os resultados, vantagens e desvantagens da implementação do novo modelo.

Para padronização das perguntas feitas aos entrevistados e para que a coleta de informações seja mais completa, utilizarei um roteiro de entrevista, composto por um questionário semiestruturado. Entretanto, a sequência das perguntas poderá ser aleatória, visando a manter o melhor fluxo da entrevista.

A entrevista é de caráter pessoal com finalidade estritamente acadêmica. O objetivo é compreender, além dos fatos, também as percepções pessoais quanto ao modelo ágil e ao processo de transição do qual o entrevistado tenha participado na organização. Portanto, poderão ser descritas opiniões pessoais em relação às oportunidades, desafios, vantagens e desvantagens do processo, além de propor recomendações que eventualmente pudessem ter sido aplicadas no decorrer do processo.

Ressalto que a entrevista será anônima. Não serão mencionados nem o nome do entrevistado e nem a respectiva organização.

A duração da entrevista será de aproximadamente 60 minutos, podendo variar de acordo com o nível de detalhe abordado por cada entrevistado. A entrevista será gravada e, posteriormente, transcrita para melhor aproveitamento do conteúdo. Depois de transcrita, será enviada ao entrevistado em questão via e-mail para maior detalhamento e feedback dos temas discutidos.

Solicito, gentilmente, consentimento para a realização desta entrevista, de acordo com os objetivos e procedimentos descritos acima.

Muito obrigada.

Mariângela Pinton 


\section{GLOSSÁRIO}

AGILE COACH - Papel de agente de mudança durante o processo de transição ágil de uma organização, garantindo que as práticas e a cultura ágil sejam absorvidas e aplicadas pelas equipes.

AGILE EXPERT (AE) - Especialista na aplicação de métodos ágeis, geralmente certificado, podendo escolher o método apropriado a ser aplicado em cada situação.

AGILE MASTER - Evolução do papel de Scrum Master, aplicando conceitos além do Scrum, tais como Lean e Kanban.

$\boldsymbol{B A C K L O G}$ - Conjunto de histórias ou funcionalidades ainda não trabalhadas pela equipe de desenvolvimento. Podem ser Backlog do Produto ou Backlog da Sprint.

BUSINESS OWNER (BO) - Papel de patrocinador do projeto, que irá traduzir a estratégia da organização para os objetivos a serem alcançados pelo Product Owner.

DAILY - Cerimônia diária do Scrum, para planejamento do trabalho.

EQUIPE (OU TIME) DE DESENVOLVIMENTO - Papel do Scrum, cujo objetivo principal é construir o produto definido pelo PO.

HISTÓRIAS - Formato de descrição das funcionalidades a serem desenvolvidas, utilizado no Scrum, com foco no que deve ser desenvolvido, no seu objetivo e em quem irá utilizá-lo.

JIRA - Ferramenta para o acompanhamento de atividades dos projetos.

KANBAN - Sistema de gestão de tarefas no modelo "puxado", geralmente por meio de um painel de gestão visual para controle das tarefas "To do", "Doing" e "Done".

LEAN AGILE CENTER OF EXCELLENCE (LACE) - Área de Transformação Digital criada nas organizações para promover a adoção do modelo ágil.

PRODUCT OWNER (PO) - Papel do Scrum, cujo objetivo principal é a definição do produto e a priorização do desenvolvimento de funcionalidades. SCRUM MASTER (SM) Papel do Scrum, cujo objetivo principal é facilitar o trabalho da equipe de desenvolvimento e remover impedimentos.

SPRINT - Ciclo de desenvolvimento do Scrum, geralmente com duração de duas semanas.

SPRINT PLANNING - Cerimônia do Scrum, em que o PO, SM e equipe de desenvolvimento priorizam as histórias que serão trabalhadas na próxima sprint.

SPRINT RETROSPECTIVE - Cerimônia do Scrum realizada ao final de cada Sprint, em que o PO, o SM e a equipe de desenvolvimento refletem sobre os pontos positivos, negativos e as ações de melhoria. 
SPRINT REVIEW - Cerimônia do Scrum, em que o PO, o SM e a equipe de desenvolvimento revisam as histórias que foram desenvolvidas na última sprint.

STORY POINTS - Unidade relativa utilizada para medir o tamanho das histórias a serem desenvolvidas em uma sprint, de forma a determinar o esforço necessário.

$S Q U A D$ - Equipe multidisciplinar que atua com objetivos específicos, geralmente agrupados por processos ou cadeia de valor.

TEAM LEAD - Membro da equipe de desenvolvimento com função de liderança. Também pode ser denominado Team Leader, quando possui um nível hierárquico superior.

USER EXPERIENCE (UX) - Profissional que garante a melhor experiência do usuário, através do design de uma interface amigável dos produtos digitais. 